\title{
WestVirginiaUniversity
}

THE RESEARCH REPOSITORY @ WVU

Graduate Theses, Dissertations, and Problem Reports

2015

\section{The Cold Culture Wars: The Fight for Democratic Education in Post-War New York}

\author{
Brandon C. Williams
}

Follow this and additional works at: https://researchrepository.wvu.edu/etd

\section{Recommended Citation}

Williams, Brandon C., "The Cold Culture Wars: The Fight for Democratic Education in Post-War New York" (2015). Graduate Theses, Dissertations, and Problem Reports. 6955.

https://researchrepository.wvu.edu/etd/6955

This Dissertation is protected by copyright and/or related rights. It has been brought to you by the The Research Repository @ WVU with permission from the rights-holder(s). You are free to use this Dissertation in any way that is permitted by the copyright and related rights legislation that applies to your use. For other uses you must obtain permission from the rights-holder(s) directly, unless additional rights are indicated by a Creative Commons license in the record and/ or on the work itself. This Dissertation has been accepted for inclusion in WVU Graduate Theses, Dissertations, and Problem Reports collection by an authorized administrator of The Research Repository @ WVU.

For more information, please contact researchrepository@mail.wvu.edu. 


\title{
The Cold Culture Wars: The Fight for Democratic Education in Post-War New York
}

\author{
Brandon C. Williams
}

\author{
Dissertation submitted to \\ the Eberly College of Arts \& Sciences \\ at West Virginia University \\ in partial fulfillment of the requirements \\ for the degree of \\ Doctor of Philosophy \\ in \\ History
}

Elizabeth Fones-Wolf, Ph.D., Chair Ken-Fones-Wolf, Ph.D.

James Siekmeier, Ph.D. Samuel Stack, Ph.D. Melissa Bingmann, Ph.D.

Department of History Morgantown, WV 2015

Keywords: Democratic Education, Intercultural Education, Cold War, Civil Rights Copyright 2015 Brandon C. Williams 


\section{ABSTRACT \\ The Cold Culture Wars: The Fight for Democratic Education in Post-War New York}

\section{Brandon C. Williams}

This dissertation explores how the American public school system has become the primary institution for citizens to project, contest, or affirm their values. Primarily, this revolves around competing ideas of democratic education. After World War II, politicians utilized the schools to propagate American democracy, while citizens viewed education as a means to reconstruct the post-war democratic order. Although most representatives acknowledged the schools needed to guard democracy and stem totalitarian aggression, few agreed on how education should accomplish such a feat. Consequently, "democratic education" deviated from its theoretical moorings and found a newly nationalistic expression in a Cold War era of scrutiny and hyper-politicization This development magnified the societal importance of the American school, as debates no longer hinged around purely education but rather over competing notions of American democracy.

Indeed, no longer were educational disputes the sole domain of rival educational camps. Rather educational disputes once contained within schoolroom walls increasingly became hashed out in New York's schools, churches, labor unions, civic centers, and neighborhoods. These educational disputes, heightened in fury, and feverish in pitch, ushered in a new era of educational controversy that became part of America's Cold Culture Wars. 


\section{ACKNOWLEDGEMENTS}

Throughout my many years in graduate school, I never encountered another doctoral student with a community-college background. Without the support of my parents, there would have been one less. Thank you Mom and Dad. 


\section{Table of Contents}

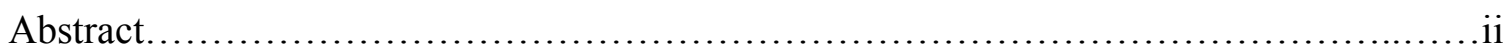

Acknowledgements ............................................................

Chapter One:

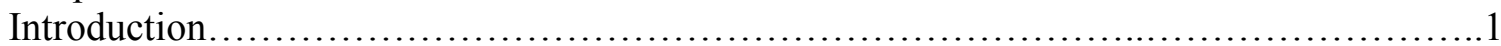

Chapter Two: Beyond Dewey:

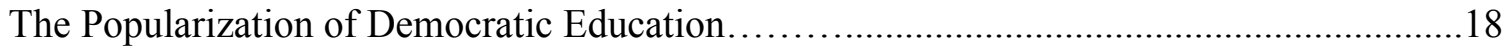

Chapter Three: Towards an Educational Arsenal of Democracy:

The Popularization of Democratic Education During World War II. ...

Chapter Four: Mutual Assured Instruction:

"Playing it Safe" with Controversial Issues in the Cold War Classroom......................118

Chapter Five: Pedagogical Brinkmanship:

Teaching Race and Russia in McCarthy's America.................................156

Chapter Six: Curricular Containment:

Bureaucratic McCarthyism, Civic Education, and the Fight for a "Living Democracy".....218

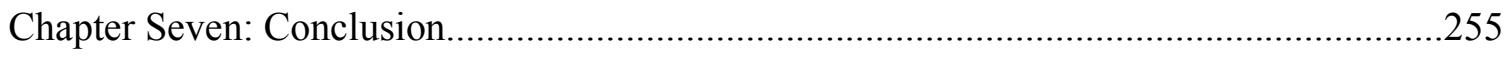

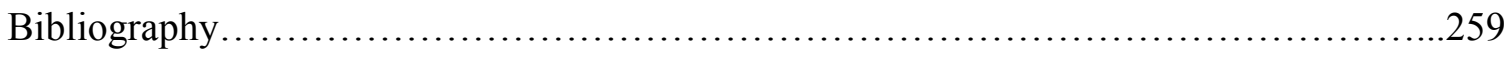




\section{Chapter 1: Introduction}

Throughout the late 1940s and early 1950s, Cold War Americans of all political stripes wrangled over the meaning of democratic education. In 1948, leading progressive thinkers, politicians, and educational luminaries gathered from across the nation to acknowledge the "father" of democratic education, John Dewey, on the occasion of his ninetieth birthday. Always modest, John Dewey criticized the "fuss and bother" as schools and universities throughout America paid "homage to the man who probably has influenced American education more than any other person." Although celebrants hailed Dewey as a progressive icon, even more people envisioned Dewey as a paragon of American democracy. Great Britain Prime Minister Clement Attlee asserted that Dewey’s influence "throughout the English speaking world" ultimately strengthened "the democratic way of life" by illustrating the "true meaning of democracy." Representative Franklin Roosevelt Jr. added, "for those of us who are striving for the implementation of his democratic philosophies in government, Dr. Dewey is a source of continuing stimulus and inspiration.” William Montague, Dewey’s close personal colleague, also praised Dewey "for teaching the world to see that the central reliance of democracy is on a free and intelligence choice made by all citizens.” Supreme Court Justice Felix Frankfurter further argued that Dewey's "robust faith" had influenced the justice's own varied thinking on "the governing forces of a democratic society." Indeed, Dewey's democratic contributions ventured far beyond the "English speaking world," as Mexico, Israel, Japan, France, Holland, Sweden, and a multitude of other nations all celebrated Dewey's democratic programs. The confluence of Dewey's democratic legacy and the global mark of his influence ultimately led the New York Times to observe that Dewey was as "solid 
as the granite" of his Vermont birthplace, and that he was deeply "American" in both "thought and outlook."1

While progressives, liberals, and educational reformers praised Dewey with democratic acclaim, a growing chorus of conservatives and anticommunists asserted that the thinker's ideals endangered American democracy. Assailing Dewey and the "patronage network of Teachers College," conservatives increasingly attributed the weakening of American schools to the decades long "infiltration" of Dewey and his legions of progressive educators. These critics impugned progressive education as staid and outdated and asserted that it uprooted American traditions and weakened American democracy. Irene Kuhn's, "Your Child is Their Target," outlined how members of this well-orchestrated "minority" sought to advance a "blueprint" for a "socialistic America" that ran counter to democratic values. Asserting that these educators sought "to accomplish the same results with our children that dictator-ruled countries have," Kuhn warned that pedagogical schemers operated in a surreptitious manner that was both “disguised" and "undercover." Noting that Dewey's students once operated under the mantra "there is no God but Dewey," Kuhn argued that subversive progressives concealed their dangerous educational plans in Deweyan theories that proclaimed to "benefit the child" and to "prepare today's child to be tomorrow's citizen." Consequently, Cold War conservatives and post-war progressives jousted over the meaning of John Dewey and his democratic ideals, thereby proving Charles Frankel's rather incisive

\footnotetext{
1 "John Dewey At 90 to Get \$90,000 Gift," The New York Times, October 19, 1949; “World Cheers Dewey at Lively 90," The New York Times, October 21, 1949.
} 
observation, “To know where we stand toward Dewey's ideas is to find out, at least in part, where we stand with ourselves."2

The pitched political tensions surrounding democratic education revealed how Cold War schools had transformed into a blank canvas for Americans to project their Cold War anxieties. Indeed, the early postwar era was a time of conflict between two competing visions of the world, one a social democratic vision that embodied campaigns for equal rights, industrial democracy, economic equality and social justice, and the other that embodied a commitment to individualism, consumerism free enterprise and the "defense of the social and economic status quo."3 Cold War New York stood at the center of these debates, as the city's political landscape nurtured the growth of progressive coalitions and reactionary politics. Thus, New York's political left--representing unionists, educational reformers, civil rights coalitions, and grassroots organizationscouched their agendas in terms of a reformist interpretation of American democracy. In doing so, they sought to empower organized labor, create a national health care system, fight for racial equality, and realize Franklin Delano Roosevelt's call for an economic bill of rights. Conversely, the power wielded by New York's leftist coalitions inspired anticommunists to respond with a political force that was detached from the paranoia and hysterics in which they are commonly characterized. As historian Joshua Freeman illustrates, anticommunist crusades in New York waged widespread political conflicts over "ideology, foreign policy, and national politics," "religious and racial conflict," and "local struggles for jobs, political influence, and cultural hegemony," that gave these

\footnotetext{
${ }^{2}$ Irene Kuhn, "Your Child Is Their Target," The American Legion Magazine, June 1952; Allen Zoll, They Want Your Child! The Real Meaning of Federal "Aid" to Education-Showing its Relation to the Whole Marxist Movement (New York: National Council for American Education, 1949), 7; Robert Westbrook, John Dewey and American Democracy (Ithaca: Cornell University Press, 1991), vi.

${ }^{3}$ Eric Foner, The Story of American Freedom (London: W.W. Norton \& Company, 1998), 252.
} 
conflicts "much of its ferocity" while making New York an "epicenter of

anticommunism." ${ }^{\prime 4}$ Thus, conservatives and anticommunists espoused their own democratic vision of post-war America, while wielding anti-communism to legitimize their attacks on social democratic movements. Consequently, post-war New York became embroiled in political battles waged over competing visions of American democracy.

As Americans increasingly clashed over the policies and values that comprised America's post-war democratic order, they turned to the schools to reinforce their political positions. Conventional narratives documenting these events largely address the waning influence of progressive educators and the rising power of anticommunists in shaping Cold War curriculum. As the story goes, progressives adopted more conservative educational policies that stressed efficiency and the school's need to create a compliant post-war workforce, while anticommunists ensured that schools promoted ideologies that were consonant with the Cold War national consensus. ${ }^{5}$ Besieged by conservatism on all sides, Cold War schools were thought to be a reflection of the nation's conservative attitudes and ideological conformity.

In focusing on New York's Cold War schools, however, this study defies the notion that the post-war era was characterized by an educational consensus. Throughout World War II and into the Cold War, New York witnessed the rise of educators, teacher unionists, and a veritable coalition of progressive and civil rights allies who used the banner of democratic education to contest conservatives influence upon post-war schools.

\footnotetext{
${ }^{4}$ Joshua Freeman, Working Class New York: Life and Labor Since World War II (New York: W.W. Norton \& Company, 2000), 72.

${ }^{5}$ Perhaps the most notable work in documenting the demise of the progressive educational movement and the rise of anticommunists is Lawrence Cremins, The Transformation of the School: Progressivism in American Education 1876-1951 (New York: Vintage Books, 1961). Joel Spring, The Sorting Machine: National Educational Policy Since 1945 (New York: McCay, 1976), reveals how progressive educators also embraced educational ideals of efficiency and using the schools to forge a Cold War workforce and facilitate job creation.
} 
Consequently, these "democratic progressives" employed the democratic rhetoric of the Cold War to legitimize their own Cold War curriculum that propagated more progressive views of race, civil rights, civics, and foreign affairs. New York's scholars, teacher unionists, and civil rights activists fought against a Cold War climate that suppressed discussions of race by branding their intercultural efforts as a democratic curriculum that addressed issues of racial discrimination and civil rights. Educational reformers such as Sabra Holbrook contested the rote nationalism of Cold War civic education by fashioning her Youthbuilders program around democratic principles that had students critically investigate issues in their local neighborhoods and communities. An alliance of democratic progressives, ranging from teacher unionists to grassroots coalitions and religious organizations, contested the Cold War's tendency to repress classroom discussions of controversial issues by publicizing these developments while also arguing than an American democracy at war necessitated that students engage in critical inquiry and grapple with polarizing issues. And members of the New York City Teachers Union embraced a democratic unionism that allied the organization with fellow democratic progressives and allowed the union to be one of the foremost authorities on civil rights and educational change. Altogether, the enduring campaigns of these democratic progressives were just a sampling of the educational figures that coalesced to champion a curriculum that empowered its citizens, provided an equality of opportunity, and advocated racial equity.

While this study documents the widespread influence of democratic progressives, it also acknowledges the tremendous power that New York's anticommunists exerted upon Cold War curriculum. Indeed, New York's anticommunists comprised a diverse 
array of individuals who used their professional and political clout to shape and influence Cold War schools. Representing the American Legion, the Knights of Columbus, veterans organizations, reactionary politicians, government officials, school administrators, conservative media, Catholic organizations, teacher committees, and concerned parents, anticommunists combated the campaigns of the democratic progressives by deploying similar tactics and terminology. As historian Clarence Taylor noted, New York's anticommunists employed tactics akin to that of grassroots activists, "printing and distributing leaflets, flyers, and other literature, sending letters to board members, and appealing to the general public." ${ }^{96}$ Anticommunists similarly wielded their own brand of democratic rhetoric, proclaiming that their own initiatives strengthened American democracy and freedom while deploring the "anti-democratic" initiatives of the democratic progressives. Altogether these professional, legal, and activist methods, helped fortify the anticommunists campaigns of New York City's educational administrators who used the Feinberg Law to dismiss progressive teachers under charges of subversion and "conduct unbecoming a teacher."

While democratic progressives and anticommunists invoked democratic education towards specific social and political causes, the widespread invocation of the term also transformed democratic education into a rather vague and nebulous concept. After World War II schools valiantly served in America's war effort, millions of Americans gravitated towards Cold War schools to invoke their own normative ideal of American democracy. Whether tasked with arming for war, preparing for peace, fighting intolerance, combating Soviet propaganda, or fortifying America's ideological defenses, democratic education

\footnotetext{
${ }^{6}$ Clarence Taylor, Reds at the Blackboard: Communism, Civil Rights, and the New York City Teachers Union (New York: Columbia University Press, 2011, 161.
} 
found a broad and varied expression as a rhetorical ploy, a movement for civil rights, a cudgel in the game of oppositional politics, and a nationalistic call to arms. Similarly, schools endorsed programs of "Strengthening Democracy" and "Zeal for Democracy," embraced curricular ideals of "living democracy," "cultural democracy," and "breathing democracy," while schools assumed titles as the "citadels," "fortresses," and "arsenals of democracy." ${ }^{77}$ Consequently, democratic education evolved into a term that meant many things to all people. Therefore, understanding democratic education's transformation into a ubiquitous, contentious, and often confusing concept, reveals how the post-war educational crises were not just waged over varying educational beliefs but also divergent interpretations of American democracy. And exploring the public debate over democratic education sheds new light on histories of Cold War schooling by illustrating that discussions about public education were not limited to educators and the schools. As debates soon flared over the school's proper role in educating for a democracy, "the entire country was drawn into the fight."

This study will explore these debates surrounding democratic education in New York City. More specifically, it argues that the conflicts of World War II and the Cold War broadened ideas of democratic education as the theory found a newly committed mass audience that endowed the philosophy with new contradictions, complexities, and meanings. As democratic education became increasingly viewed as the "first line of

\footnotetext{
${ }^{7}$ Historian Robert Hampel characterized schools as "citadels" stemming from educator George Stoddard's 1944 image of high schools, President Franklin D. Roosevelt is largely attributed calling schools and colleges "fortresses," while historian Charles Dorn notes how Americans called for education to become "arsenals for democracy"; Carl Bankston and Caldas, Public Education: American's Civil Religion; Robert L. Hampel, The Last Little Citadel: American High Schools Since 1940 (Boston: Houghton Miffilin, 1986); Charles Dorn, American Education, Democracy, and the Second World War (New York: Palgrave MacMillan, 2007), 6 .

${ }^{8}$ Geoffrey Perrett, Days of Sadness: Years of Triumph: The American People, 1939-1945, Volume 1 (Madison: University of Wisconsin Press, 1985), 374.
} 
defense" during World War II, the theory deviated from its theoretical moorings and took on a new function as an arm of national security. The Cold War further broadened the term as the ideological nature of the conflict led Americans to focus on public schools as the primary agent to defeat Communism worldwide. While these heightened expectations of Cold War schools further popularized democratic education, they also intensified the nation's educational differences as Americans fought to promote their own normative ideas of democracy within public schools. These conflicting ideas, all operating under the banner of democracy, reflected the contradictory roles of Cold War schools as both promoters of democratic expression and guardians of American ideas of freedom. Whether the battle was over textbooks, curriculum, teachers, intercultural education, or controversial issues, educational advocates internalized these disputes as expressions (or protection) of a "democratic tradition" within their profession, while the public saw their concerns stemming from a fervent commitment to both "democracy" and "education." In this sense, people divided over an ideological dispute raised the banner of "democratic education" while speaking of two different interpretations of democracy.

Educational historians initially approached the dilemma of democratic education from a theoretical perspective. Lawrence Cremin's path-breaking thesis that the progressive educational movement was a continuous presence from 1876 to 1955 embodying both benevolent and democratic impulses has invited much discussion from scholars. ${ }^{9}$ Subsequent "radical revisionists," writing against the contentious educational backdrop of the 1960s, integrated studies of race, class, and gender, to see "who gained and who lost" in these battles, defying Cremin's "simplistic" narrative of benevolence

\footnotetext{
${ }^{9}$ Lawrence Cremins, The Transformation of the School: Progressivism in American Education 1876-1951 (New York: Vintage Books, 1961).
} 
and democracy. ${ }^{10}$ While at times deterministic and conspiratorial, these studies made key contributions by illustrating the discriminatory impact of early $20^{\text {th }}$ century educational reform upon immigrants, women, and minorities.

My study makes a significant contribution by showing that the broadening of "democratic education" allowed all groups to ground their ideals in the nation's democratic creed. Proponents of democratic education faced both under-represented groups speaking in democratic terms and new mandates of patriotic accountability. ${ }^{11}$ During the Cold War, educational administrators often had to defer to the nation's democratic fervor and entertain educational initiatives they might have previously dismissed. At the same time, powerful reactionary and anticommunist forces used similar tactics to propound their views. Consequently, in Cold War New York, debates over

\footnotetext{
${ }^{10}$ Among these historians Michael Katz, The Irony of Early School Reform: Educational Innovation in mid-nineteenth century Massachusetts (Boston: Beacon Press), 1968, argued the bureaucratic centralization of public education was established for the benefit of middle and upper classes. Other historians have built upon Katz's study like Martin Lazerson, Origins of the Urban School: Public Education in Massachusetts, 1879-1915 (Cambridge, Harvard University Press, 1971) who argued that vocational education was constructed as a means to curb working class and immigrant advancement, while Colin Greer and Carl Kaestle asserted public school's primary function was to assimilate or Americanize immigrants in a process that led to discrimination against minorities. Colin Greer, The Great School Legend: A Revionists Interpretation of American Public Education (New York: Basic Books, 1972); Carl F. Kaestle, The Evolution of an Urban School System: New York City 1750-1850 (Cambridge: Harvard University Press, 1973). As other historians questioned the data, and conspiratorial nature of these works, educational historians would offer early organizational studies on these processes with Joel Spring, The Sorting Machine: National Educational Policy Since 1945 (New York: McCay, 1976) arguing that organization figures used the schools to serve national, foreign, or economic interests, while David Tyack argued the school centralization of "The One Best System" created a lumbering bureaucracy removed whose reliance upon "expertise" instead of "local knowledge served to undermine public participation in the schools, prevent flexible responses to its students, and to reject local, cultural, racial, and ethnic values. David Tyack The One Best System: A History of American Urban Education (Cambridge: Harvard University Press, 1974). Later organizational studies rejected many of these class-oriented interpretations with Paul Peterson, The Politics of School Reform: 1870-1940 (Chicago: The University of Chicago Press, 1985), rejecting that school centralization pitted the working class against the public school, and noting the preeminence of "organizational imperatives," accommodation, and pluralistic politics driving educational decisions. Similarly, Joel Spring expanded upon The Sorting Machine by noting how educational politics were driven by layered relationships of teachers unions, school administrators, private foundations, think tanks, politicians, special interest groups, boards of education, courts, and "the knowledge industry." Joel Spring, Conflicts of Interest: The Politics of American Education, $3^{\text {rd }}$ ed. (New York: The Mc-Graw-Hill Companies, Inc, 1997)

${ }^{11}$ Mary Dudziak, Cold War, Civil Rights: Race and the Image of American Democracy (Princeton: Princeton University Press, 2000)
} 
educational policy became an arena in which a variety of groups asserted their visions about what sort of society America should become. By expressing their own ideas of "democratic education," Cold War New Yorkers also expressed an explicit faith in schools to inculcate proper democratic attitudes and behaviors in addition to enhancing the skills, beliefs, and opportunities of its citizens. ${ }^{12}$ As historian Carl Bankston notes, "Americans increasingly came to see education as the way that they could remake themselves." 13

This renewed faith in post-war education has led historians to depict Cold War schools as "civic temples" catechizing democratic doctrines or as lofty "citadels" preserving democratic ideals. ${ }^{14}$ According to Dianne Ravitch, this newly-defined role of schools as "instruments of national purpose" attracted the attention of both reformists and critics. ${ }^{15}$ However, as external events polarized Americans, this often contradictory role of Cold War schools increasingly led New Yorkers to perceive school programs along "anti" and "pro" democratic lines. New York soon became embroiled with battles over teachers, curriculum, textbooks, and controversial issues. Central to these debates was a growing fear of communism and its influence on the New York Teachers' Union (TU). Previous studies have often ignored the educational contributions of the Union in their

\footnotetext{
${ }^{12}$ See David Tyack and Larry Cuban, Tinkering Toward Utopia: A Century of Public School Reform (Cambridge: Harvard University Press, 1995) who argue American's faith in schools as the "agency" to better society has led to consistent school reform movements where groups have attempt to define and create model citizens through public schooling. Historian Carl Bankston similarly sees Americans faith in schools as a "civil religion" to solve its social, economic, and political problems as leading reformers to exaggerate the functions and abilities of public education. Carl Bankston and Stephen Caldas, Public Education: America's Civil Religion, A Social History (New York: Teachers College Press, 2009) ${ }^{13}$ Carl Bankston and Stephen Caldas, Public Education: America's Civil Religion, 3.

${ }^{14}$ Carl Bankston and Stephen Caldas view Cold War Schools as "civic temples" while historian Robert Hampel characterized schools as "citadels" stemming from educator George Stoddard's 1944 image of high schools. Carl Bankston and Caldas, Public Education: American's Civil Religion; Robert L. Hampel, The Last Little Citadel: American High Schools Since 1940 (Boston: Houghton Miffilin, 1986).

${ }^{15}$ Dianne Ravitch, The Troubled Crusade: American Education 1945-1980 (New York: Basic Books Inc, 1983), xii.
} 
insistence on portraying the TU leadership as either led by Soviet puppets or innocuous reformists, while depicting anticommunists as either valiant patriots or as black hats. ${ }^{16}$

This study seeks to extricate these educational debates from suffocating historiographies that marginalize the dedication of Communist teachers, dismiss the democratic faith of New York's anticommunists, and divorce the city of New York from its schools. This study also illustrates how New York conservatives responded with fear and uncertainty to a Communist left that they perceived as making "anti-democratic" incursions into New York's schools. ${ }^{17}$ Building upon recent social histories, my research suggests that Communists' experiences in schools, neighborhoods, and workplaces shaped their "democratic" campaigns moreso than their party philosophies. ${ }^{18}$ This study also echoes current educational histories that view these educational confrontations as not problems to "be eliminated," but rather as manifestations of democracy within public life. ${ }^{19}$ As New Yorkers increasingly voiced their ideas of "democratic education," they

\footnotetext{
${ }^{16}$ Robert Iverson, Communists and the Schools (New York: Harcourt Brace and Company, 1959) focuses solely on the TU's subversive or Communist bent thereby obscuring the union's contributions, educational legacy, and commitment to democratic education. Conversely, Celia Zitron institutional history of the TU and Ruth Markowitz's examination of Jewish TU teachers offer insightful studies, yet they are largely victim-centric studies examinations that skirt the issue of the TU's Communist involvement. Celia Zitron, The New York City Teachers' Union, 1916-1964 (New York: Humanities Press, 1964); Ruth Markowitz, My Daughter the Teacher: Jewish Teachers in the New York City Schools (New Brunswick: Rutgers University Press, 1993). This works aims to follow the approach in Clarence Taylor, Reds at the Blackboard: Communism, Civil Rights, and the New York City Teachers Union (New York: Columbia University Press, 2011) that acknowledges the union's commitment to Communist Party philosophy, while also giving credit to the TU's often autonomously driven programs of educational commitment.

${ }^{17}$ Joshua Freeman, Working Class New York, 72.

${ }^{18}$ For studies on how neighborhoods, communities, culture, and experiences shaped activists and those involved in the Communist Party see Lizabeth Cohen, Making a New Deal: Industrial Workers in Chicago, 1919-1939 (Cambridge: Cambridge University Press, 1990); Fraser Ottanelli, The Communist Party of the United States: From the Depression to World War II (New Brunswick: Rutgers University Press, 1991); Rosemary Feuer, Radical Unionism in the Midwest, 1900-1950 (Chicago: University of Illinois Press, 2006); Randi Storch, Red Chicago: American Communism At Its Grassroots, 1928-1935 (Urbana: University of Illinois Press, 2007).

${ }^{19}$ In David Tyack, Seeking Common Ground: Public Schools in a Diverse Society (London: Harvard University Press, 2003), Tyack sees conflicts over public education as representations of democracy in a "diverse city." Jonathan Zimmerman similarly sees educational reoccurring "culture wars" as indicative of
} 
expressed an optimistic portrait of post-war society that they projected upon the schools.

This helps explain why one educational historian has asserted that the problems of New

York and its schools, "are the problems of other American cities on a magnified scale;

because the stage is larger and the confrontations are more vivid, the issues ... sharper in focus than elsewhere. $" 20$

Finally, by merging these conceptual frameworks, this study hopes to bridge a problematic gap in educational history. In "The American School Curriculum Goes to War," curricular historian O.L Davis noted that there is a tendency for educational historians to "divide the $20^{\text {th }}$ century into pre and post-war eras." This neat periodization of the 1940s separates residual World War II issues from the Cold War and largely frames post-war educational battles as emanating from an entirely new set of issues raised by anticommunist or civil rights showdowns. ${ }^{21}$ My research shows that Americans did not emerge from the war with a triumphant interpretation of democracy but rather with a complicated one formed by wartime experiences. The events of World War II and the Cold War broadened ideas of democratic education as the theory found a newly committed mass audience that endowed the philosophy with new contradictions,

democracy's continuing vitality in public schools. Jonathan Zimmerman, Whose America: Culture Wars in the Public Schools (Cambridge: Harvard University Press, 2002).

${ }^{20}$ Freeman, Working Class New York, 72; Dianne Ravitch, The Great School Wars: A History of the Public Schools as Battlefields of Social Change, New York City, 1805-1973 (New York: Basic Books, Inc., 1974), xxxiii.

${ }^{21}$ O.L. Davis, "The American School Curriculum Goes to War, 1941-1945; Oversight Neglect and Discovery," Journal of Curriculum and Supervision 9, no. 2 (1993): 126; For a great summary of educational historians omissions and advancements in World War II historiography see Charles Dorn, American Education, Democracy, and the Second World War, 4-7, 13-18. Other advancements have also recently made in Roy Lowe, trans., Education and the Second World War: Studies in Schooling and Social Change (London: The Falmer Press,1992), which attempts to examine international trends in education during World War II, to allow historians to generate comparative approaches to the study of the history of education. Also Ronald D. Cohen, "World War II and the Travail of Progressive Schooling: Gary, Indiana, 1940-1946," in Schools in Cities: Consensus and Conflict in American Educational History, ed. Ronald K. Goodenow and Diane Ravitch (New York: Holmes and Meier, 1983, 263, focuses on how the international conflict of World War II influenced Gary's educational policy. 
complexities, and meanings. Ultimately, Americans' heightened democratic expectations of wartime schools fed into the post-war period, creating a dizzying and often contradictory array of expectations for Cold War schools. Previously latent wartime issues became magnified, entirely new programs emerged, and once heralded wartime programs became dismantled under Communist fears of subversion. As ideas of democracy became contested in mass politics, school conflicts soon waged over whose version of "democratic education" to accept.

Chapter 2 will explore the origins and early development of democratic education within New York City as well as the origins and early history of the New York City Teachers Union, one of the strongest advocates of democratic education in New York City. In examining democratic education from its origins to the Great Depression, this chapter will illustrate how democratic education developed into a more expansive idea embraced by a wider array of educational thinkers. Indeed, democratic education had its roots in the progressive education movement, which sought to make schools more effective agencies of democratic society. It was also inextricably connected to the intercultural education movement, which sought to use the schools to create a more inclusive and democratic society by addressing issues of minority achievement and cultural democracy. Despite its progressive origins, the reformist ideas behind democratic education were often hamstrung by conservative influences seeking to bureaucratize America's schools. Yet, the onset of the Great Depression created a national sense of disillusionment that led the American public to turn towards the schools to recapture their nation's democratic spirit. Consequently, progressives voiced a new faith in democratic education that resonated with Americans who wished to use the schools to revive their 
democratic institutions. Therefore, bringing democratic education into orbit with unionists, intercultural thinkers, and more radical theorists, illustrates how democratic education departed from its more insulated and theoretical origins and developed into a term embraced by a broader portion of the American public.

Chapter 3 illustrates how the exigencies of World War II uprooted democratic education from its theoretical moorings and brought the term into a more public arena for Americans to debate. Contesting historians who contend that World War II represented a conservative era in education, this chapter will show how the exigencies of conflict created fertile ground for more radical educational programs. During the 1930s, the alarming growth of totalitarian governments ultimately brought new interest to the core ideas behind democratic, progressive, and intercultural education while reinforcing the need for a modernized variant of these ideas. Consequently, a group of democratic progressives were able to legitimize their more radical educational programs by rooting their ideas in the political vocabulary of World War II. Interculturalists attacked the dangerous racial philosophies of Nazi Germany by creating programs that addressed racial inequality and Northern Jim Crow. Teachers deviated from previous practices that kept them insulated from the community and now approached neighborhoods as a curricular laboratory to solve civic and democratic problems. Historians and scholars collaborated in order to create a democratically constructed curriculum that addressed the inability of schools to prevent two consecutive World Wars. Thus, democratic progressives made crucial inroads into wartime schools by positioning their programs as a democratic means to combat totalitarian incursions. As the conclusion of World War II heralded a new era, educators, Americans, and the state each sought to reconstruct the 
Cold War classroom on their own terms. Therefore, exploring the coterminous development of democratic, intercultural, and progressive education illustrates how democratic education deviated from educational circles and found itself entrenched in the political vocabulary of the Cold War.

Chapter 4 begins with World War II by examining key ideological shifts as wartime schools transitioned into Cold War citadels. It will primarily explore how the idea of promoting "controversial issues" transitioned from a wartime measure of national security into what some saw as subversive cloak of Communist subterfuge. ${ }^{22}$ During World War II, educators and administrators called for schools to explore controversial issues so that students could diagnose Fascist strains of propaganda. Additionally, history found renewed importance as educators urged students to critically apply the "democratic lessons "of the past to contemporary wartime events. However, as schools retreated to even more defensive postures during the Cold War, the examination of controversial issues threatened to undermine the Cold War status quo. Reactionary groups labeled the pursuit of controversial issues as a subversive vehicle for teachers to spread "antidemocratic doctrines." Subsequently, teachers feared entering into debates pertaining to race, Russia, or current affairs. Although Cold War administrators rarely criticized the pursuit of controversial issues, they circumscribed teachers' authority by firing radical teachers and discouraging discussions of anti-American ideals. In turn, teachers, unions, and educational organizations decried these "anti-democratic" changes as neglecting to prepare "democratically-minded" students for the grave realities of a post-war world.

\footnotetext{
${ }^{22}$ While many historians have explored the expansion of pragmatic curricula to meet war-time demands (physical education, vocational and military training, civics, etc), New York's proximity to pace-setting educational institutions created entirely new conservations that would later take on national importance.
} 
Chapter 5 explores the fight over democratic education in regards to Cold War curriculum. As previously addressed, the Cold War repressed classroom discussions of race and Russia under the rationale that such dialogues served as vehicles for Communist subterfuge. Democratic progressives countered these anticommunist attacks by promoting their own curricular campaigns as a more pure embodiment of democratic education. Consequently, members of the New York City Teachers Union spotlighted the pernicious influence of racist textbooks used in New York schools, many of which were authored by New York's administrators. This enabled the TU to position their own black histories and intercultural supplements as a more fair and democratic account of the nation's history. Similarly, democratic progressives responded to a "climate of fear" that often suppressed classroom discussions of Russia by arguing that the patriotic motives behind these campaigns served rather anti-democratic ends. Consequently, democratic progressives mobilized educational supporters by publicizing and surveying the impact of this repression upon Cold War curriculum. Organizing in national meetings, creating surveys, and writing in journals and newspapers nationwide, democratic progressives managed to make the suppression of Cold War classrooms a key focal point in discussions over American schools. These discussion, occurring alongside the nation's highly publicized educational crisis, ultimately reveals that battles over Cold War curriculum were not as passive, conservative, or serene as historians have previously suggested.

Chapter 6 explores the prevailing concerns and controversies over civic education in post-war New York. In the immediate years of the Cold War, New York's schools endorsed the installation of the Youthbuilders program, which instructed teachers and 
students on the benefits of political issues and community activism. As the Cold War developed, however, the nation's desire for civic education to validate the Cold War's national consensus often conflicted with the unpredictable issues Youthbuilders students addressed in their communities. As this chapter will show, the New York City school administration destroyed this nationally venerated program through the practice of bureaucratic McCarthyism, which ultimately defanged the more radical aspects of Youthbuilders, while keeping the program in line with more conventional civic instruction. Rather than tear out the instructional "heart" of their courses, Youthbuilders leaders willingly ended their pioneering program. Collectively, these chapters will explore how conflicting issues over race, religion, citizenship, and world affairs animated the central educational conflicts occurring outside schoolroom walls. Beginning during World War II and operating under conflicting banners of democratic education, these Cold Culture Wars ultimately created an educational template that made the schools one of the most politically contestable institutions in America today. 


\section{Chapter 2: Beyond Dewey: The Popularization of Democratic Education}

"To know where we stand toward Dewey's ideas is to find out, at least in part, where we stand with ourselves." —_Charles Frankel

During the early twentieth century, educators, unionists, and a range of other progressives invoked democratic education as a means to strengthen society and improve the public good. In 1906, teacher unionist Margaret Haley wrote a letter to Jane Addams linking teacher unionism to the public interest. "For seven years, I have led the teachers in a struggle to prevent the last institution of democracy, the public schools, from becoming prey to the dominant spirit of greed, commercialism, autocracy, and all the attendant evils," Haley noted, "If you could know how deeply I feel that the perpetuation of our democratic republic depends on the success of the struggle." Similarly, educational theorist John Dewey wrote in support of Henry Linville's New York City Teachers Union in 1927, arguing that if teachers embraced the democratic principles of teacher unionism they could "put into execution the ideas and ideals written about and talked about by progressive educators and reformers than by any other one cause whatsoever." ${ }^{2}$

Interculturalists advocated democratic education as a means to enhance society by fighting racial prejudice. Early interculturalist Rachel DuBois argued that teachers must develop programs of racial and ethnic diversity, "as leaders of youth in a free public school system in a Democracy are responsible for giving facts to young people with whom they must live in a social body." Other interculturalists echoed DuBois and argued that the democratic power of the schools could play a key role in confronting racial discrimination. Consequently, declarations of democratic education's overriding power

\footnotetext{
${ }^{1}$ Robert Westbrook, John Dewey and American Democracy (Ithaca: Cornell University Press, 1991), vi.

2 "Why I Am a Member of the Teachers Union, Box 2, Folder 1, Teachers' Union of the City of New York, 1916-1964. 5015. Kheel Center for Labor-Management Documentation and Archives, Cornell University Library (hereafter cited as Records of the New York City Teachers Union).
} 
reverberated throughout New York's schools and universities. These ideals permeated educational discourse to such an extent that Richard Hofstadter observed that "American educationalists" seemingly attached their democratic causes to every educational initiative, while simultaneously launching "into wild cadenzas about democracy and selfrealization." Thus, while progressives voiced seething critiques of industry and American capitalism, reformers declared an ardently optimistic faith in the democratic potential of America's schools. ${ }^{3}$

While many of his followers came to view John Dewey as the "father of democratic education," the history of how the idea developed into a broader and more popularized usage has more complex origins. Democratic education had its roots in the progressive education movement, which sought to make schools more effective agencies of democratic society. Writing Democracy and Education in 1916, Dewey argued for students to become active inquisitors in their schools and communities in order to make sense of the societal forces that influenced their daily lives. In this way, Dewey popularized democratic education by arguing that it could turn schools into a "constructive agency" of social change by forging critically involved students who would become "constituents" of an improved "future society." These writings ultimately resonated among thousands of progressive educators who filled the posts of American schools, teacher-training institutions, and universities. Despite this progressive momentum, Dewey's vision of reform and social change occurred alongside the bureaucratization of America's urban schools. Thus, the progressive vision of using education to reform and remake society was often hamstrung by urban school districts

\footnotetext{
${ }^{3}$ Diana Selig, Americans All: The Cultural Gifts Movement (Cambridge: Harvard University Press, 2008), 105; Richard Hofstadter, Anti-Intellectualism in American Life (New York: Vintage Books, 1962), 340.
} 
that believed schools should construct stability and social order. While some progressive educators conceded authority to bureaucratized schools, interculturalists and teacher unionists invoked their own conceptions of democratic education to legitimize their educational initiatives. ${ }^{4}$ Ultimately, the onset of the Great Depression emboldened these educational campaigns as capitalism's collapse led the American public to uphold the schools as America's last surviving democratic institution. Gathering more public acclaim in the 1930s, democratic education expanded beyond the realm of Dewey and the educational progressives and became a rallying cry for Americans to both remake and rebuild society through the schools..$^{5}$

This chapter examines the evolving meaning and interpretation behind democratic education from the early twentieth century to the Great Depression. Historians have conducted sprawling examinations on the pervasive influence of John Dewey and democratic education. ${ }^{6}$ Similarly, a small yet insightful group of studies has explored the early history of intercultural education and the New York City Teachers Union. ${ }^{7}$ This

\footnotetext{
${ }^{4}$ Perhaps the best works exploring how the increasing bureaucratization of American schools hampered efforts at educational reform are in David Tyack, The One Best System: A History of American Education (Cambridge: Harvard University Press, 1974) and Diane Ravitch, Left Back: A Century of Failed School Reforms (New York: Simon \& Schuster, 2000), 56, 88-129.

${ }^{5}$ John Dewey, Democracy and Education: An Introduction to the Philosophy of Education (New York: Macmillan, 1916), 85; David Tyack et. al., Public Schools in Hard Times: The Great Depression and Recent Years (Massachusetts: Harvard University Press, 1984),

${ }^{6}$ Westbrook, John Dewey and American Democracy, provides the most comprehensive account of John Dewey's philosophies and his evolving thoughts on American Democracy. Gary Bullert, The Politics of John Dewey (Buffalo: Prometheus Books, 1983) provides a less biographical account that focuses more on John Dewey's evolving political philosophies and activities.

${ }^{7}$ Insightful works documenting the early origins of intercultural education include Selig, Americans All, as well as Nicholas Vincent Montalto, "The Forgotten Dream: A History of the Intercultural Education Movement, 1924-1941 (PhD Diss, University of Minnesota, 1977). Clarence Taylor, Reds at the Blackboard: Communism, Civil Rights, and the New York City Teachers Union (New York: Columbia University Press, 2011), provides the best analysis of the early history of the New York City Teachers Union and the union's intercultural efforts. For other works that explore the early years of the New York City Teachers Union, see Marjorie Murphy, Blackboard Unions: The AFT and the NEA, 1900-1980 (Ithaca: Cornell University Press, 1990); Philip Taft, United They Teach: The Story of the United Federation of Teachers (Los Angeles: Nash, 1974); William Edward Eaton, The American Federation of
} 
chapter aims to build upon these works by weaving these histories into a more intertwined and collective analysis of democratic education's origins and subsequent popularization. In bringing democratic education into orbit with unionists, intercultural thinkers, and more radical theorists, I argue that democratic education departed from its more insulated and theoretical origins and developed into a term embraced by a broader portion of the American public. Revealing these insights ultimately establishes how and why the American public has gravitated towards the schools as the primary institution to improve society's democratic potential. Furthermore, understanding how democratic education developed from an educational ideal into to a political and social ideal, sets the foundation for this dissertation and the educational clashes that later sparked America's Cold Culture Wars.

The liberal democratic theory of education invoked by Thomas Jefferson and refined by John Dewey stems from a tradition of "utopian" educational thought that views schooling as the foremost agency to confront societal issues and mold responsible citizens. ${ }^{8}$ Both Jefferson and Dewey believed knowledge, diffused throughout American society, led to the creation an active, involved citizenry that could recast government and create a more democratic society. Yet, while Dewey authored sprawling works discussing the myriad utilities of such knowledge, Jefferson believed the pursuit of knowledge

Teachers, 1916-1961 (Carbondale: Southern Illinois University Press, 1975); Celia Lewis Zitron, The New York City Teachers Union: 1916-1964 (New York: Humanities Press, 1968).

${ }^{8}$ See David Tyack and Larry Cuban, Tinkering Toward Utopia: A Century of Public School Reform (Cambridge: Harvard University Press, 1995), who argue American's faith in schools as the "agency" to better society has led to consistent school reform movements, in which groups have attempted to define and create model citizens through public schooling. Historian Carl Bankston similarly believes that the American faith in schools functions as a "civil religion," leading reformers to exaggerate public education's ability to solve America's social, economic, and political problems.. Carl Bankston and Stephen Caldas, Public Education: America's Civil Religion, A Social History (New York: Teachers College Press, 2009). 
should serve decidedly political ends. Writing against a backdrop of revolution and agrarian rebellion, Jefferson advocated for the construction of a trifurcated system of schooling where lower tiers of education developed republican citizens, while higher education focused on cultivating future republican leaders. Through this curious fusion of meritocracy and elitism, universal education instructed the citizen, whereas higher education raked "geniuses...from the rubbish" in order to cultivate an "aristocracy of talent" that provided leadership to the towns and wards comprising America's "little republics." ${ }^{\text {9 }}$ Yet from 1890 to 1920, Jefferson's vision of bucolic America evaporated as dramatic increases in immigrants and rural to city migration led to soaring enrollments throughout American schools.

In adapting Jeffersonian ideals to the "corporate-industrial" age, Dewey constructed a more inclusive philosophy to counter the "authoritarian" excesses wrought by industrialization. ${ }^{10}$ Writing Democracy and Education in 1916, Dewey believed this newfound industrial order necessitated a more democratic education that empowered "all its members" in the "vast panorama of human affairs." 11 Thus, knowledge did not merely cultivate civic doctrine and responsible leaders, but rather served as a vehicle to engage in an "active struggle" against a society that produced "mechanical" relationships and a "formal institutionalizing of life." 12 Accordingly, vocational courses should not serve industrial ends "narrowly conceived for the masses," but should rather provide intellectual "points of departure" that enabled children to become "masters of their own

\footnotetext{
9 Joel Spring, The American School: 1642-1996. $4^{\text {th }}$ ed. (New York: The McGraw Hill Companies Inc., 1997), 57-59; David Tyack, Seeking Common Ground: Public Schools in a Diverse Society (Cambridge: Harvard University Press, 2003) 18-19.

${ }^{10}$ Gary Bullert, The Politics of John Dewey (Buffalo: Prometheus Books, 1983), 11.

${ }^{11}$ John Dewey, Democracy and Education, 29; Lawrence Cremin, The Transformation of the School: Progressivism in American Education 1876-1957 (New York: Random House, 1961), 126.

${ }^{12}$ Dewey, Democracy and Education, 99.
} 
economic and social fate."13 Ultimately, Dewey believed these "democratic experiences" broke down "barriers of class, race, and national territory" as students engaged in a "communicated experiences" and a "mode of associated living."14 While many progressives sought reform through political avenues, Dewey believed the schools presence outside prevailing power structures and inside the active "consciousness" of a community made education the dominant agency of "social reform." 15

As some progressive educators embraced Dewey's philosophies, educational institutions underwent crucial transformations that blunted his democratic ideals. Indeed, the idea of progressive education was used by reformers in multiple and often contradictory ways. While Dewey championed the school's power to rectify societal issues, a growing chorus of critics painted urban schools as wasteful bastions of inefficiency, prone to political corruption and outmoded decision making. According to historian Diane Ravitch, critics who also identified themselves as progressives ultimately led urban schools. These administrative progressives, often called "educational experts," believed schooling that educated the immigrant, the working class, and elite under a similar curricular umbrella embodied "anti-democratic" principles. ${ }^{16}$ Fueled by the "unstoppable momentum" of social efficiency, these curricular specialists and educational administrators promoted pragmatic utility over intellectual growth, by channeling children into a "differentiated curriculum" befitting of students rank and ability. ${ }^{17}$ Consequently, Dewey's ideal of democratic education for all was transformed

\footnotetext{
${ }^{13}$ William J. Reese, America's Public Schools: From the Common School to "No Child Left Behind." $2^{\text {nd }}$ ed. (Baltimore: John Hopkins University Press, 2011), 141; Lawrence Cremin, The Transformation of the School, 124.

${ }^{14}$ Dewey, Democracy and Education, 86-97

${ }^{15}$ John Dewey, The Public and its Problems (New York: Henry Holt), 149.

${ }^{16}$ Ravitch, Left Back, 56, 88-129.

${ }^{17}$ Ravitch, Left Back, 86,
} 
into an industrial education for the masses and continued academic preparation for the few. This created special problems for educational instruction as Dewey's followers strove to integrate child-centered philosophies of adjusting society to the child in an instructional environment that increasingly harnessed children to the existing social order.

Although America's earlier patchwork of community schools may have marginalized the scope of such curricular policies, the increasing centralization of separate urban schools into a unified "one best system" only served to amplify the new expert's influence across district borders. Consisting of elite business leaders, university presidents, and upper-class professionals, a group of "administrative progressives" constructed a corporate model of education that consolidated educational authority under a corp of trained administrators who emphasized efficiency and integrated bureaucracies. ${ }^{18}$ Ultimately, these reformers believed that rerouting the power of community schools to a more centralized educational leadership, would insulate city schools from external "political forces," while restoring "rationality" and "expertise" to the process of educational decision-making. In being shorn free from community lay boards that they viewed as too parochial and antiquated, these reformers argued they could usher in a more coherent and efficient slate of educational reforms that pinned "down responsibility within the [school] organization" and accorded "professionals

\footnotetext{
${ }^{18}$ While at times, the "new expert" and the "administrative progressives" filled similar positions and occupied overlapping bounds of authority, I feel it is important to make a crucial designation. In discussing the "new experts," I refer specifically to those reforms expressly enacted within the schools, while my exploration of "administrative progressives" refers to outside, urban reformers seeking to engender structural, and bureaucratic change in public education. Thus, the "new experts" include the superintendent, and his associated staff of curricular specialists, established pedagogical experts, educational psychologists, and university presidents, deans, and professors. Administrative progressives include business leaders, "professional men," the "successful people" filling school boards and committees, and the corporate board of directors. To note these designations, visit Ravitch, Left Behind, 88-129, and Tyack, The One Best System, 7, 128.
} 
autonomy within their individual spheres." ${ }^{19}$ Although reformers rationalized that this corporate model of education kept "the schools out of politics," the shift of educational authority away from neighborhood parents, teachers, and school leaders mitigated the grassroots involvement and community engagement that once typified local schools. In addition, this empowerment of centralized school boards ultimately impaired the democratic expression of local school leaders while uprooting democratic social arrangements that patterned local school districts for decades.

By the early twentieth century, the guiding tenets of administrative progressives created a puzzling and often contradictory relationship between Dewey's ideals and his progressive followers. On an instructional level, the professionalization of teachers, trained in the scientific and pedagogical philosophies of the "new expert" accorded educators an increase in salary, benefits, and job protection. Conversely, classroom teachers' professional standing at the bottom of education's corporate hierarchy meant educators functioned more as "half-professionals," balancing a multitude of directives emanating from their superiors. Contending with daily management from the principal, administrative policy of the school board, and executive decisions from a superintendent, the classroom teacher now taught in an environment that increasingly circumscribed their autonomy and denied rights associated with their professional status. Historian Marjorie Murphy notes this development affected neighborhoods as well, as professionalization divorced teachers from their community by reinforcing a "sense of loyalty not to the community, but to the school principal, superintendent, and educational professoriate." ${ }^{20}$ Consequently, urban schools of the "one best system" ceased to reflect a democratic

\footnotetext{
${ }^{19}$ Tyack, The One Best System, 167.

${ }^{20}$ Marjorie Murphy, Blackboard Unions, 23.
} 
governing body as school centralization transformed traditional lines of authority in school administration. Accordingly, teachers grew detached from instructional affairs, while administrative forces encouraged the public to remain deferential to the educational authority of the expert. Historian David Tyack asserts this educational bureaucratization stymied the realization of Dewey's philosophies, as his prescriptions required substantial autonomy on behalf of the teachers, children, and the community--something that the educators of the "new order" often lacked. ${ }^{21}$ As Dewey noted, the "intelligence of the teacher is not free; it is confined to receiving the aims laid down from above."22

The reverberation of these educational transformations throughout New York's communities and neighborhoods created a rather perplexing pedagogical predicament. New York had always been home to education's foremost thinkers and pace-setting institutions, but now these same forces confronted a modern, yet conservative bureaucracy overseeing curriculum, instruction, and reform. Although administrative progressives often consulted theorists who sought to translate Dewey's ideas into practice, they did so on the implicit understanding that these theories posed "little threat" to the existing educational order. As a result, the aims and intent of democratic educational thought became increasingly adulterated as they filtered throughout the bureaucratic layers of educational administration. Indeed, this explains how even Dewey's most fervent acolytes could create instruction that ran contrary to the thinker's designs. Thus, the dissonance between democratic educational theory and actual educational practice created a complicated and difficult road for those progressives who

\footnotetext{
${ }^{21}$ Tyack, The One Best System, 167. Tyack also noted that when Dewey described teachers who best represented his ideas of democratic education, he touted "small and private schools" rather than large public systems.

${ }_{22}$ Dewey, Democracy and Education, 109.
} 
thought society was better served by bringing Dewey's ideals into New York's classrooms and surrounding communities. ${ }^{23}$

The creation of social studies as an instrument of civic guidance reflects the growing contradictions between democratic education and administrative progressivism. In the early twentieth century, educators increasingly derided history as an antiquated field devoid of utility or contemporary relevance. Ultimately, many progressives believed the social complexities wrought by immigration, conflict, and ethnic strife necessitated a more modernized approach to the study of history, which engaged students with a past that helped illuminate the "vital problems" of the present. ${ }^{24}$ But injecting history with a civic obligation of interpreting the present imbued the field with contradictory impulses that irrevocably altered the discipline's role in the American classroom. On one hand, progressives like Dewey believed history's democratic function should abstain from indoctrinated, predetermined facts, and rather cultivate critical thinking that endowed students with a "command over ... the instrumentalities through which society carries itself along." ${ }^{25}$ Yet, social efficiency advocates feared that such loosely defined historical instruction, predicated around individualistic critical thought, could be contorted to engender social transformation and inculcate radical doctrine. Rather, the social efficiency wing argued that a properly constructed social studies course should serve as a patriotic tool of civic guidance, familiarizing students with the pantheon of America's hallowed events and iconic figures.

\footnotetext{
23 Tyack, The One Best System, 196-197; Ravitch, Left Behind, 59, 95.

${ }^{24}$ Edward Krug, The Shaping of the American High School (New York: Harper \& Row Publishers, 1964), 355.

25 Thomas Fallace, "John Dewey on History Education and the Historical Method," Education and Culture 26, no. 2 (2010), 22.
} 
Thus, social efficiency advocates moved to circumscribe the instructional function of history as a means to create a more "orderly society." Starting in 1913, the Committee of Reorganizing Secondary Education (CRSE) of the National Education Association (NEA) issued a series of reports that sought to redefine the curriculum of the American high school. As Dianne Ravitch notes, "no field was as profoundly affected by the deliberations of the CRSE as history." 26 Originally introduced as a means to "civilize" blacks by studying "qualities necessary for the race to advance," social studies now wedded history to associated disciplines of sociology, economics, and civics as a means to cultivate "proper citizenship." ${ }^{27}$ Indeed, this newfound impetus behind the "Social Studies" stemmed from Americans linking their xenophobic concerns to the school's burgeoning immigrant population. A New Jersey school administrator personified this linkage noting, "The influx of foreigners, with their divergent personal ideals and antagonistic racial traits, imposes upon the schools an infinitely difficult problem."28 Thus, social efficiency progressives turned to the schoolroom to harness the country's disparate immigrant blocs into a unified culture. Rationalizing social studies' linkage to citizenship and order, the committee argued "the purpose of democracy is so to organize society that each member may develop his personality primarily through activities designed for the well-being of his fellow members and of society as a whole." 29

Although social studies' multi-disciplinary approach and lofty rhetoric promised innovative instruction, curricular theorists ultimately packaged the field to reinforce

\footnotetext{
${ }^{26}$ Ravitch, Left Back, 127.

${ }^{27}$ Michael Lybarger, "Origins of the Modern Social Studies: 1900-1916," History of Education Quarterly 23, no. 4 (1983), 457.

${ }^{28}$ Zoe Burkholder, Color in the Classroom: How American Schools Taught Race: 1900-1954 (Oxford: Oxford University Press, 2011), 19.

${ }^{29}$ Ravitch, Left Behind, 124.
} 
America's nationalistic designs to a mass audience. Noting that history "must answer the test of good citizenship," the committee urged that social studies should emphasize, "the history of our own country than that of foreign lands; the record of our own institutions and activities than that of strangers; the labors and plans of the multitudes than the pleasures and dreams of the few." While the committee responded to World War I with the progressive endorsement of World History as a means to foster "international spirit," the report also underscored the curriculum's need to address world events while emphasizing America's "national ideals, national loyalty" and "national self-respect." In New York City, this ultimately meant that teachers taught a version of World History which emphasized the "superiority of Anglo-Saxon traditions" and students examined the foreign contributions of peoples who best resembled Anglo-Saxon stock. Thus, social efficiency advocates" belief that the study of history could "no longer be regarded as an end to itself," rested on the idea that the "ends" of history should not be independently found, but rather preselected and predetermined. In the "Origins of Modern Social Studies," historian Michael Lybarger sums up the contradiction this presented for progressive advocates, noting that "the view of the world embodied in the Hampton social studies and popularized by the work of the Committee was not a democratic one. Rather it sought to legitimate social, economic, and political inequality." Indeed, the views disseminated by the CRSE played an influential role in shaping educational curriculum, as schools often adopted its recommendations or used its curricular designs as an instructional frame of reference. ${ }^{30}$

\footnotetext{
${ }^{30}$ Krug, The Shaping of the American High School, 353-361; Lybarger, "Origins of the Modern Social Studies," 456.
} 
The conservative footprint cast by the CRSE curtailed the expression of innovative instruction fueled by democratically-oriented grassroots educational campaigns. For example, the achievements and limitations of the "cultural gifts movement" exemplifies the obstacles activists faced as they attempted to integrate substantive democratic reform in the classroom. In the 1920s and 1930s, high school educator Rachel DuBois spearheaded a sweeping antiprejudice crusade to confront America's resurgent wave of nativism and racial prejudice. DuBois also sought to redress the curricular failings present within the social studies curriculum. Situating the school as America's racial and ethnic "meeting ground," DuBois created in-school assembly programs where students, teachers, and administrators alike highlighted the cultural contributions of various racial and ethnic groups to America's democratic creed. ${ }^{31}$ These cultural gifts programs drew from Dewey's philosophy that "democratic experiences" broke down "barriers of class, race, and national territory" by immersing students in ethnic cultures, where they dramatized interpretations of Jewish stories, conducted readings of black poets, and witnessed speeches from "racial representatives" about their culture and community. ${ }^{32}$ These lessons provided students new historical material often obscured in Social Studies lessons and textbooks. Thus, cultural gifts became a powerful presence throughout the interwar period, as it confronted America's rising tide of racial prejudice by seeking to have the schools construct a more racially inclusive conception of American identity.

In placing the schools at the forefront of American race relations, Dubois had to temper the program's more radical potential. Despite pulling from similar research that

${ }^{31}$ Selig, Americans All, 94.

${ }^{32}$ Dewey, Democracy and Education, 86-97. 
emphasized the role of community attitudes and racial segregation in fomenting racial prejudice, DuBois avoided political advocacy and avoided challenging the economic, political, and social inequalities that pervaded New York's communities. Even John Dewey, DuBois' chief influence, advocated for the importance of cultural contacts while noting that "without political and economic changes these factors will not go far in solving the problem." ${ }^{\prime 3}$ In her study of antiprejudice education, historian Diana Selig notes that DuBois' omission of structural and socioeconomic critiques was "most likely intentional. ${ }^{\prime 34}$ Indeed, the institutionalization of DuBois' programs throughout New York's schools exposed her efforts to a greater array of people concerned about cultural gifts' reach and influence. Furthermore, mounting economic hardships wrought by the Great Depression aroused fears that antiprejudice education could radicalize already alienated immigrant youths by linking America's racial past with the immigrant's current economic condition. Thus, cultural gifts' liberal orientation threatened to destabilize the order that social studies curriculum sought to ensure. Throughout the 1920s and 1930s, Dubois encountered funding rescissions from educational organizations, fitful cancellations by cautious administrators, and accusations of her "Bolshevik leanings, refusal to salute the flag, and belief in interracial marriage" from community groups. ${ }^{35}$ Perhaps to ensure their continuation, DuBois' programs straddled a precarious instructional balance that addressed the wrongs of racial categorization while avoiding discussing racism's structural realities. This restricted approach often led DuBois' teachings to adopt a more "narrowed reading" and stereotypical description of minority groups where, "Italians were emotional and musical; Jews excelled in science; Chinese

${ }^{33}$ Selig, Americans All, 211.

${ }^{34}$ Selig, 89.

${ }^{35}$ Selig, 75 . 
were stoic, quiet, and patient." ${ }^{36}$ Consequently, DuBois' emphasis on immigrant "gifts" perpetuated and even encouraged the use of ethnic stereotypes, a process which the movement's thinkers were ironically trying to dispel. To compound the problem, DuBois eschewed the community activism that other intercultural activists advocated, reaching out only to invite the "most cultured" racial representatives who best resembled the Anglo-American traits of her school audience. Although DuBois' influences championed "critical-thinking" as a tool to enlarge students" "mental outlook" about racial discrimination, cultural gifts favored activities that restricted student expression, such as plays, readings, poems, and presentations. ${ }^{37}$

Cultural gifts' limitations regarding African-Americans were even more pronounced. The program's refusal to address issues of segregation and racial discrimination created an instructional world that was not truly reflective of black students daily realities. For example, cultural gifts downplayed African-American contributions by differentiating between the accomplishments of blacks and Europeans, while also marginalizing the impact of racial violence, Jim Crow laws, lynching, and disenfranchisement upon black life. Even DuBois' discussion of black spirituals neglected to illustrate the historical context in which the songs were constructed "from the terrors of slavery. ${ }^{38}$ By excising cultural gifts of its radical thrust, DuBois' program assumed a safe and often conservative approach that snipped at the tendrils of racism while avoiding its social and economic roots and broader social and economic impact.

Bound between a codified curriculum and a "one best system" that muted grassroots pedagogies, teachers had few available avenues to empower their role in

\footnotetext{
${ }^{36}$ Selig, 13.

${ }^{37}$ Selig, 34, 77.

${ }^{38}$ Selig, 88.
} 
instructional affairs. In his pathbreaking study, Are American Teachers Free, historian Howard Beale prefaced his exploration of "Pedagogical Problems" by noting that "No more important problem of freedom exists than the teacher's relations to the selection of texts, the making of the curriculum, the choice of teaching methods ... and his own selfimprovement while he teaches." Yet, Beale concluded that the school board, superintendent, supervisors and principals "usually determine the curriculum," while teachers "rarely have a real voice in the matter." 39

One of the most well-documented investigations into the New York City Public School System (NYCPSS) affirmed Beale's findings. The 1913 "Hanus Report" blasted the inflexibility of New York's "High School Course of Study" as "undemocratic, unsocial," and "unpedagogical." The report partially attributed these problems to teachers' growing detachment from curricular decisions, observing that "teachers, as a rule, are conscientious and energetic ... In respect to their profession, they are static and depressed ... No one in the system is discussing aims and principles with them and showing how these could affect their teaching." Consequently, the report argued that teachers' curricular ostracization led to courses that neglected to resonate with New York's diverse population. Thus, the report called upon local teachers to have an expanded role in creating their own local course of study that "kept in touch with the real needs of the community it is designed to serve and in harmony with contemporary educational principles." Yet, the Hanus Report's incendiary critiques and lofty solutions failed to provoke reform. City officials often overlooked the report's structural recommendations in favor of evidence that rationalized continued budgetary controls

\footnotetext{
${ }^{39}$ Howard Beale, Are American Teachers Free?: An Analysis of Restraints Upon the Freedom of Teaching in American Schools (New York: Charles Scribner's Sons, 1936), 320, 330.
} 
over New York's schools. Although the report had a marginal impact on school curriculum, it did highlight the restiveness of reform-minded educators seeking to democratize teachers' influence in instructional affairs. ${ }^{40}$

These developments ushered in a decade of stability and conservative educational thought. In the 1920s, prosperous urban districts throughout America constructed thousands of new high schools to accommodate the influx of urban and immigrant students. Correspondingly, administrators embraced scientific approaches to more efficiently manage their students, while also adapting existing curricula to ensure societal order. Although these developments impinged upon teachers' curricular autonomy, successful salary campaigns and the continued elevation of professional status often reduced resistance to instructional change. Thus, the rift between conservative and radical progressive wings became less pronounced as "social reformism was virtually eclipsed by the rhetoric of child-centered pedagogy." Indeed, in a time of such economic and educational abundance, few educators felt compelled to challenge the existing educational order. ${ }^{41}$

Consequently, many teachers sought out teachers unions to shear through bureaucratic control and enhance their voice in educational change. Formed in 1916, the New York City Teacher's Union (TU), or Local 5, became the first teachers' union in the city. Founders Henry Linville and Abraham Lefkowitz acknowledged the "static and depressed" conditions of New York's teachers and asserted their union would be a force to fight for "dignity," "proper conditions," and a "share in the control of the schools."

\footnotetext{
${ }^{40}$ Report of Committee on School Inquiry, New York City Board of Estimate and Apportionment, 19111913, 13, 31, 15. Teachers College Library.

${ }^{41}$ Cremin, The Transformation of the School, 181.
} 
Indeed, the TU Constitution vowed to increase teachers role in democratic education and community involvement through "cooperating with parents associations," "promoting the participation of teachers in school administration," and "providing for the systematic study of school problems by teachers." ${ }^{2}$ Pledging to "stand for democracy in its particular branch of everyday life," TU leaders bolstered their platform with a radical labor ideology that fused their backgrounds in labor organization and socialist agitation. Linking trade unionism to educational organization, TU leaders saw no harm in deploying aggressive tactics--such as delegations, pickets, community outreach, and the sophisticated use of media — to achieve their objectives.

Yet, Linville and Lefkowitz's militant brand of unionism conflicted with the NYCPSS' standards of professionalism. The professional ideal of the "new teacher" desired a pliant, politically restrained teaching force committed to "careers" over labor. This “culture of professionalism" ultimately crept into teachers' extracurricular life, encouraging educators to abstain from fringe politics and community involvement that might taint their professional status. Conversely, Linville believed that unionism restored the democratic voice of teacher and community to a system that discluded such engagement. By extension, the TU employed militant tactics to fight for rights that professionalization promised to ensure yet failed to achieve. Educational historian Marjorie Murphy noted unionism's linkage to mass action and community, observing that

\footnotetext{
42 "Why Join the Teachers Union," New York Teachers Union, Box 2, Folder 1, Records of the New York City Teachers Union; Lana Muraskin. "Professionalism and Radicalism In the New York City Teachers Union, 1927-1935" (presentation, Annual Meeting of the American Educational Research Association, New Orleans, Louisiana, February 1973).
} 
"unionism implied both a political stance and a community agenda" whereas "professionalism implied hierarchy and isolation."

Although the NYCPSS' "locus of power" clearly resided within its professional bureaucracy, administrators often exaggerated school's community participation and teacher input as a means to pacify external educational pressures. The TU ultimately exposed this façade by seeking to mobilize the educational constituencies that New York's schools professed to serve. Thus, while the "one best system" insulated schools from external political forces, the TU sought to project these forces back into the schools. In times of peace and political normalcy, such outside organization met with conflict. The communist paranoia spawned by World War I amplified these confrontations, exposing TU members to pedagogical scrutiny and political investigation.

The TU's extracurricular activity triggered city-wide fears over how union members' political ideals translated into their classroom instruction. In 1919, the New York State Legislature commissioned the Lusk Committee to investigate Bolshevik incursions into New York's schools. The New York Times endorsed these investigations, highlighting the instruction of "Bolsheviki" fomenters who sought "to poison the young with fatal teachings. ${ }^{44}$ Consequently, the Lusk Committee aimed its investigations at teachers who refused to sign loyalty oaths affirming their commitment to both state and federal governments. Proclaiming to uphold teacher's educational rights, TU Legislative Representative Henry Linville vigorously defended these targeted teachers at the expense of the union's limited "energy and funds." Ultimately, the philosophical disputes undergirding these conflicts reflected conflicting interpretations over democratic

\footnotetext{
${ }^{43}$ Murphy, Blackboard Unions, 35, 45.

44 "Bolsheviki In This State," The New York Times, March 22, 1919, 14.
} 
instruction. Patriotic organizations believed oaths insured teachers loyalty to American democratic values and freedom, while opponents viewed oaths as an abrogation of their educational and political liberty. Thus, refusing to sign an oath either constituted an antidemocratic act of disloyalty or a respect of America's democratic protections and processes. Believing the former, the Lusk Commission strove to eliminate the TU's influence upon New York's schools and communities. In its most damaging assault on teacher organization, the commission undercut union leadership and organizational strength by denying the TU's ability to meet on school grounds. As Lefkowitz noted, "We suffered isolation, harassment, and the denial of the use of the schools. Antagonism to teacher-unionism resulted in the dismissal of three of our ablest teachers. ${ }^{45}$ Coupled with publicized investigations and firings, these actions painted an image of disrepute upon the union that ultimately helped reduce union membership from 1500 to 800 . Indeed, this supports Marjorie Murphy's argument that professionalism represented a "powerful antiunion slogan that effectively paralyzed and then slowed the unionization of teachers." 46

The anti-communist spectre of these investigations left a conservative imprint upon the New York City Teachers Union. In the 1920s, the TU witnessed a gradual "mellowing" of the union's labor philosophies and a protracted debate over how to best construct a unionism fit for professionals. These discussions ultimately led the union to temper its militant tactics and radical rhetoric in favor of less contentious tactics such as appointments and letter-writing campaigns. Furthermore, the union rid its politicized

\footnotetext{
${ }^{45}$ Lana Muraskin. "Professionalism and Radicalism In the New York City Teachers Union, 1927-1935" (presentation, Annual Meeting of the American Educational Research Association, New Orleans, Louisiana, February 1973).

${ }^{46}$ Murphy, Blackboard Unions, 1.
} 
platforms of free speech and teacher's expanded role in curricular affairs, and moved towards investigative studies of less contentious issues such as hygiene, janitorial services, and supervisory standards for teacher observations. As Lara Muraskin has argued, what appeared to be a "neat pairing" of professionalism and unionism ultimately became the "acceptance of professional goals and of rather conservative union means to attain them. ${ }^{" 47}$ While the union occasionally pursued confrontational issues such as teacher salaries, it largely abandoned its democratic plank that aimed to empower teachers and the local community. Thus, TU leaders fought to preserve their union's respectability and survivability, while distancing themselves from the militant trade unionism that once informed their values.

As a result, Linville and the TU entered the 1920s with a seemingly uncharacteristic sense of conservative unionism aimed at preserving the union and recovering its professional respectability. Historian Marjorie Murphy has shown that the professionalization of American teachers led educators to embrace a more conservative brand of unionism that downplayed leftist politics in order to pursue programs of "narrow self-interest" and economic uplift. ${ }^{48}$ Indeed, throughout the $1920 \mathrm{~s}$, the TU shifted from more militant demands to embrace issues of janitorial services, health standards, and studies of school conditions. Furthermore, the union jettisoned its more militant approach of mass action and demonstrations in favor of more conservative means such as luncheons, lobbying, and conferences. Union leaders backing these more moderate and unobtrusive union philosophies often jousted for seniority and made bids to join New York's administrative ranks. While the union occasionally pursued confrontational issues

\footnotetext{
${ }^{47}$ Muraskin, "Professionalism and Radicalism in the New York City Teachers Union."

${ }^{48}$ Murphy, Blackboard Unions, 1, 6.
} 
such as teacher salaries, they largely abandoned their democratic plank that aimed to empower teachers and the local community. As historian Lana Muraskin has shown, this relentless quest for respectability was ultimately built on an "uneasy foundation" that sought the "acceptance of professional goals and of rather conservative union means to attain them. ${ }^{\circ 49}$ Indeed, the onset of the Great Depression ultimately ruptured this brokered peace, facilitating the rise of the Communist-led Rank and File caucus that desired a return to the union's more militant glory. Besieged by union factionalism, Linville and Lefkowitz departed the TU in order to construct the New York Teachers Guild in their own conservative image of teacher professionalism. "When Henry Linville left," one Communist teacher noted, "we had our own union."

Historians have debated the causes for the 1935 split. Earlier studies attribute the root cause of this 1935 schism to a cabal of Communist splinter groups seeking to wrest control of the TU and oust its existing leadership. Stressing the powerful emergence of the Rank and File, these studies argue that the caucus deployed Soviet-style tactics of mass militancy and sectarian rhetoric in its eventual bid for union takeover. ${ }^{51}$ Thus, these studies view the Rank and File's aggressive approach as an aggressive embodiment of Communist Third Period policies, which sought to initiate a "boring from within" strategy to work with and eventually "seize" control over unions and American labor. ${ }^{52}$ While this view has some merit, this approach disavows the Rank and File's legitimacy by reductively painting its campaigns as Soviet inspired treachery wedded to Communist ideals and aimed at undermining American labor. Ultimately, this approach casts a pall

\footnotetext{
${ }^{49}$ Lana Muraskin. "Professionalism and Radicalism In the New York City Teachers Union, 1927-1935."

${ }^{50}$ Murphy, Blackboard Unions, 158.

${ }^{51}$ These studies largely include, Philip Taft, United They Teach; Dodd, School of Darkness; William Edward Eaton, The American Federation of Teachers; Iverson, The Communists and the Schools.

${ }^{52}$ Iverson, Communists and the Schools, 26-27.
} 
over the entirety of TU history as its decades of social activism and educational commitment are viewed as mere vehicles for Communist subterfuge.

Given that the TU's beginnings are used to taint its legacy, it becomes increasingly important to both rehabilitate and reassess the origin story of the embattled union. While the Rank and File followed Communist Party directives and continued to do so years after assuming the mantle of union leadership, viewing the group through the lens of party policy obscures the maelstrom of social and cultural transformations that marked the swirling educational landscape of the 1930s. Younger, more radical, and intentionally choosing positions at black schools, Rank and Filers were not only more involved, but also uniquely attuned to the professional and educational degradations wrought by the Great Depression. Indeed, the economic downturn inflicted a crippling devastation upon New York's schools, spurring salary cuts, the elimination of teaching positions, and a precipitous decline in school funding. Thousands of licensed and credentialed teachers languished among the ranks of the unemployed as New York's schools hired substitutes to perform full-time work for half-pay and no benefits. Conditions in African-American schools were even worse. Many Communist teachers taught in black schools that often lacked indoor plumbing and were characterized by fire commissioners as borderline "firetraps." And since students sought refuge in the schools, Communist teachers contended with swelling enrollments, doubled class sizes, and "double" or "triple" shifts that decongested classrooms by rotating students into morning or afternoon sessions. Consequently, many Communists came to view the TU leaders' indifference and unwillingness to grapple with these developments as a testament to the union's increasing political distance from educational issues. Thus, Rank and Filers 
increasingly branded Linville and Lefkowitz as a politically outdated and ineffectual duo interested in serving the union's self-interest, while remaining blinded to the educational problems occurring outside union halls. ${ }^{53}$

The Great Depression merits reconsideration as the primary driver in shaping the militancy and radical labor consciousness of Rank and Filers who guided the union until its dissolution. In his study of Jewish socialists of New York, historian Tony Michels characterized leftist Jews as being engaged in "long encounter" with "radicalism of all kinds" that defied "easy description." ${ }^{54}$ This rings true for Jewish Communists of the TU, where Communism operated in an intricate and complicated political milieu shaped by teachers' professional experiences and everyday life. Thus, Rank and Filers did not embrace Communism in order to break from democratic tradition but rather because they believed Communism provided the best means to combat the educational indignities heaped upon black students and professional teachers. As Marjorie Murphy observed, "the focus of the new teacher in the thirties was the community and the teacher as an empowering agent, bringing to the masses ... class analysis of education which rejected the potentially elitist characteristic of professionalism." ${ }^{55}$ Thus, Communists of the TU pursued their ideology with an inveterate sense of militancy, meshing the orthodoxy of the Communist Party with a labor ideology that was uniquely democratic and attuned to the marginalized voices in their professional and social orbit. Adhering to this dynamic, the Rank and File approached the TU as a vehicle to agitate for issues of race, civil rights,

\footnotetext{
${ }^{53}$ For examinations of the Great Depressions effect's on New York schools, much of which is listed here, see Murphy, Blackboard Unions, 131-149; Dianne Ravitch, The Great School Wars: New York City, 18051973 (New York: Basic Books Inc., 1974), 233-240; Zitron, The New York City Teachers Union, 126-135; "Link Old Harlem Schools to Unrest," The New York Times, April 11, 1935.

${ }^{54}$ Tony Michels, A Fire In Their Hearts: Yiddish Socialists in New York (Cambridge: Harvard University Press, 2005), 259.

${ }^{55}$ Murphy, Blackboard Unions, 154-155.
} 
education, and working-class politics that later became the hallmark of New York's "social democratic polity.",56

The depression not only split the TU but it also ruptured this sense of educational harmony. Tethered to languishing local economies, schools underwent massive cutbacks retrenchment, just as new child labor laws kept more children in children in American schools. Thus, school districts faced historic decreases in funding while also accommodating students enrolled in schools longer than ever before. To meet these demands, school districts turned to wage cuts, while also decreasing teachers' salaries and doubling class sizes. Other educators found their teaching load increased as they instructed students in separate waves, conducted throughout morning and evening “double-sessions.” Additionally, school districts scaled back on full-time positions, appointing a mass of cheaper, part-time "substitutes" as replacements for regular teachers. ${ }^{57}$

These educational calamities wrought by the Great Depression were part of a larger industrial and political collapse that led Americans to question the strength of their democratic institutions. Investigations into the tenability of democratic governance pervaded American journals, which featured articles such as "Is Democracy Bankrupt," “Has Democracy Broken Down,” and "Is Democracy a Failure.” Indeed, the Depression's “potentially fatal challenge to representative government" led some

\footnotetext{
${ }^{56}$ As Freeman observes, this social democratic polity included a comprehensive vision that espoused an "expansive welfare state, racial equality, and popular access to culture and education." Freeman, Working Class New York, 55.

${ }^{57}$ Murphy, Blackboard Unions, 131-136; Celia Zitron, The New York City Teachers Union: A Story of Educational and Social Commitment, 1916-1964 (New York: Humanities Press, 1968), 24-28.
} 
Americans to call for an open reorganization of political and capitalistic processes. ${ }^{58}$ Bankers, industrialists and politicians conducted clandestine meetings that proposed dictatorial solutions to solve America's economic problems. This led historian James Truslow Adams to assert that in times tinged with the passing of democracy, Americans had begun to look "toward Rome" for political inspiration. ${ }^{59}$

Although most Americans were preoccupied with the fate of the nation's economic and political institutions, educators mounted the most heated and ideological defense of America's schools. Teachers interpreted the educational degradation facing public schools as an affront against a sacred institution that more than any other provided an "opportunity for living that are the very life of our democratic civilization." Believing education's plight to be the cause of "wicked leaders from above," teachers took special offense at political and business leaders seeking school budget cuts. Thus, many teachers believed that they could no longer remain politically neutral in a climate where education's decline was linked to failed political policies. This led teachers to reconceptualize their professional and educational philosophies as they heightened their militancy to meet the growing demands confronting American education. ${ }^{60}$

In seeking radical solutions to the schools' problems, educators once again turned to Dewey to fortify their positions. Dewey's vision of an educational world unfettered by external forces resonated with reformers who felt besieged by political and capitalistic influence. Consequently, reformers stressed Deweyan ideals of democratic instruction as

\footnotetext{
58 "Charles, Maurras, “Is Democracy Bankrupt?” Outlook, 143 (June 2, 1926), 177; "Has Democracy Broken Down: A Debate," Forum, 81 (January, 1929), 37; Will Durant, "Is Democracy a Failure?" Harper's Magazine, 153 (October, 1926), 565.

${ }^{59}$ Edward Purcell, Jr, The Crisis of Democratic Theory: Scientific Naturalism \& the Problem of Value (Lexington: The University Press of Kentucky, 1973), 126-27.

${ }^{60}$ David Tyack et. al., Public Schools in Hard Times: The Great Depression and Recent Years (Massachusetts: Harvard University Press, 1984), 47.
} 
a means to purify schools, empower communities, and improve society. The most incendiary call for such a transformation came in George Counts' 1932 Progressive Education Association (PEA) speech “Dare Progressive Education Be Progressive." In his speech, Counts proclaimed that the failure of capitalism and existing political leadership warranted the creation of an instructional body that was situated to create social change. Counts went on to assail the conservatism of social efficiency. Counts conjoined his modern appeals to Deweyan principles, blasted teachers as "romantic sentimentalists," and called into question a teaching force that had "been timid about issues of social justice, that was socially conservative in reflecting middle-class values in its official and hidden curriculum, and that had sought for decades to portray schools as a sacred domain above politics." He then called upon progressive reformers and educators to develop an "organic relation with the community," confront every "social issue," and to craft a "challenging vision of human destiny." Afterwards, the audience avoided conventional applause, sat in silence, and tabled their agenda to immediately debate the repercussions of Count's "clarion call.",61

With its fiery rhetoric, Counts's speech helped spark a "Social Reconstructionist" movement that dramatically reimagined the role of teachers and schools in strengthening democratic life. These Social Reconstructionists, or "frontier thinkers," envisioned schools, communities, and industries as vital entities organized around democratic lines. Schools and teachers played a special role in this arrangement, as their teachings reconstructed future societies by prioritizing social progress over political and industrial need. In discussing their ideals, however, the "frontier thinkers" had a penchant for

\footnotetext{
${ }^{61}$ George S. Counts, "Dare Progressive Education Be Progressive?" Progressive Education 9 (April 1932): 257-263; John Beineke, And There Were Giants In The Land: The Life of William Heard Kilpatrick (New York: Peter Lang, 1998), 201.
} 
arcane treatises and "exhortation" that obscured their more pragmatic solutions for educational change. Indeed, the movement's flair for "high rhetoric" has even led historians to dismiss the Reconstructionist legacy, branding the movement as a crusading faith incapable of transcending educational practice. ${ }^{62}$

Although the social reconstructionists failed to change official educational practice, the movement did influence educational thought. Nearly all strains of progressive theory arose battered and bruised by a Depression that spotlighted deficiencies in educational reform. While some educators merely repackaged "familiar ideas" in new garb, the Social Reconstructionists reframed Deweyan ideals around the exigencies of the depression. ${ }^{63}$ Their ideas injected new life into the wing of progressive reform that emphasized democratic education. Most importantly, the Social Reconstructionists condemned institutional and authoritative forces that impeded democratic educational reform, which they viewed as critical to the creation of a new social order. George Counts called upon teachers to become politically active and attacked the school's contradictory placement as a politically democratic institution that was supposed to be "above politics."

Educational professor William Kilpatrick, often overshadowed in the pantheon of Social Reconstructionist thought, crafted one of the most modern condemnations of traditional educational policy. A pupil of Dewey himself, Kilpatrick rose to educational prominence with the 1918 publishing of the Project Method, which envisioned the educative experience as a process of living that stayed not "in the schoolroom" but rather

\footnotetext{
62 Tyack, Public Schools in Hard Times, 61.

${ }^{63}$ Tyack, Public Schools in Hard Times, 24.
} 
reached "out into the surrounding community." ${ }^{64}$ In what some have coined "learning as living, living as learning," the project method's confluence of school and community led students to link purpose and democracy as they pursued social questions guided by their own self-interest. ${ }^{65}$ By avoiding instructional habits of compulsion, Kilpatrick argued, students engaged in "experiences" more likely to produce socially-minded participants in a democratic society. Yet, Kilpatrick's vision of adaptive curricula, student-centered instruction, and community involvement rarely witnessed a full adoption in the American classroom.

In the midst of the Great Depression's increasingly radical climate, Kilpatrick attacked the structural impediments inhibiting democratic reform. In his 1932 article "Professional Education from the Social Point of View," Kilpatrick criticized the tendency of administrators to construct curriculum that "raised no ugly questions" and "played it safe regarding controversial issues." He blasted the "anti-democratic" nature of school administration that often disparaged "democracy," and called for shared decisions that "began with its teachers." Furthermore, he denounced the "scientific and impersonal" approach toward education and called upon teachers to become more involved in the community. To Kilpatrick, developing community-minded educators required a professional teaching force that was not "trained," but rather educated with the ability to help others "become intelligently capable and independent in his thoughts and actions." This "social outlook," Kilpatrick argued, should pervade the schools from "top to

\footnotetext{
${ }^{64}$ Quoted in Andrew Hartmann, Education and the Cold War: The Battle for the American School (New York: Palgrave Macmillan, 2008), 23.

${ }^{65}$ Hartmann, Education and the Cold War, 22.
} 
bottom." Altogether, Kilpatrick's views comprised one of the more direct, blistering assaults on the modern pedagogical forces shaping American schools. ${ }^{66}$

With the combined educational heft of John Dewey, George Counts, Harold Rugg, and William Kilpatrick, the Social Reconstructionists proposed a democratic reformation of both school and society that attracted the attention of some teachers, superintendents, and educational reformers. This leadership, emanating from education's most prolific theorists, provided a vital platform for educators, as frontier thinkers disseminated their thoughts throughout educational journals, energetic meetings, and affiliated teacher-training institutions. Indeed, the ideas perpetuated by the Social Reconstructionists were part of a broader current of educational thought that argued for the schools' expanded role in American affairs. In articulating their views from some of the most publically connected posts in Depression-era educational leadership, Social Reconstructionists provided a "set of problems and possibilities around which an educational philosophy of the public could be worked out." ${ }^{27}$ Thus, the Reconstructionist vision of a school that could "remake the world" soon garnered an intense public enthusiasm, as the rise of European totalitarianism led Americans to cast teachers as the newfound guardians of American democracy. ${ }^{68}$

\footnotetext{
${ }^{66}$ William Heard Kilpatrick, ed. The Educational Frontier (New York: The Century Company, 1933), 257286.

${ }^{67}$ Beineke, And There Were Giants In The Land, 222; John Dewey, Harold Rugg, and William Kilpatrick represented one of the most influential and publically connected trios in educational thought. In the 1930s, Dewey remained one of the most heavily consulted educational theorists, while Harold Rugg authored the nation's most popular textbook series. Kilpatrick wielded the most quantifiable influence, eventually instructing 35,000 students at an institution responsible for churning out the "most articulate leaders in education," and occupying a senior chair that exuded a "prodigious influence on educational theory and practice." For a discussion of Kilpatrick's influence on educational practice, see Lawrence Cremin, The Transformation of the School, 215-221.

${ }^{68}$ Tyack, Public Schools in Hard Times, 19.
} 
Throughout the 1930s, the confluence of war and depression would lead the American public to vigilantly champion democratic education more than ever before. Indeed, the emergence of totalitarian regimes throughout Europe appeared to signify a foreboding "wave of the future" that led Americans to view the schools as the primary bulwark to channel democracy's strength and repel authoritarian aggression. Consequently, the teacher unionists and interculturalists already radicalized by the Great Depression used the rhetoric of democratic education to strengthen and broaden the influence of their radical initiatives. Dewey protégée William Kilpatrick used his own democratic ideas to argue for the creation of "teacher-citizens" to combat "Hitlerism" in all its forms. And New York's schools relaxed some of the more bureaucratic obstacles addressed in this chapter and sought to create schools that were involved in communities and fluidly responsive to the exigencies of war. Although educational historians have shown how wartime schools adopted increasingly conservative initiatives during World War II, the next chapter reveals how the conflict facilitated the rise of "democratic progressives" who used the war to forge distinctly radical educational initiatives. Ultimately, these developments would the educational tensions that aggravated America's Cold 


\section{Chapter 3: Towards an Educational Arsenal of Democracy: The Popularization of Democratic Education During World War II}

"The historian of the future will undoubtedly record a significant change in the interests and outlook of these official leaders of education in the twenty-five years that culminated with the world-shaking events of 1940." - - Social Frontier

In August 1939, leading educators, statesmen, philosophers, lords, and industrial magnates from across the world convened at Columbia University's Teacher College to set up an educational program "for the defense and advance of democracy." Assembling in what the New York Times called, "probably the most significant conference of its kind ever held by an educational institution," the "Congress on Education for Democracy" began with a warning that if democracy was to be saved "it must be done now." Three days later, the mainstream press branded the congress as an unmitigated success. Writing amid a backdrop of depression and totalitarian expansion, President Franklin Delano Roosevelt lauded the gathering, noting that "democracy can not long stand unless its foundation is kept constantly reinforced through the process of education." Speakers recited addresses only to repeat the same speech minutes later in overflow audiences packed in nearby gymnasiums and classrooms. Audiences braved the sweltering August heat and remained consistent in number throughout the day, while radio listeners tuned in from South America, Europe, and the United States. As the story was told, differences had been shelved, people united, and the "cause of democracy" was "safe in the schools."

\footnotetext{
1 "The Minds of Educational Administrators in 1941," Frontiers of Democracy, March 16, 1941.

2 "Dr. Butler Warns We Must Act Now To Save Democracy," New York Times, August 16, 1939; "To Define Hold of Democracy," New York Times, 13 August 1939; Charles Dorn, American Education, Democracy, and the Second World War (New York: Palgrave Macmillan, 2007), 2; "Democracy Fight Made Permanent," New York Times, August 18, 1939.
} 
Beneath the rhetorical surface, however, a more contradictory image of the conference emerged. While critics noted the "baccalaureate platitudes," "harmless platitudes," and "vague and platitudinous" speeches pervading the general sessions, they also highlighted the ideological divides coursing throughout the specialized seminars. Addressing the schools' role in combating German propaganda and teaching controversial issues, Lord Earl Baldwin proclaimed the "republic is at stake" if educators stray from the "facts," while U.S. Commissioner of Education John Studebaker encouraged schools to submit controversies "to a vigorous process of critical and free inquiry." In discussing foreign and domestic threats, Studebaker proposed an increase of educational democracy to "defeat the totalitarian regimes," while H.W. Prentis, Jr., of the National Association of Manufacturers (NAM) assailed the National Labor Relations Act as a "democratic" encroachment upon American liberty and urged the schools to "save the republic" from American democracy. And while conservative businessmen from the Chamber of Commerce, NAM, and Chase National Bank voiced open opposition against teacher unions, both The Nation and The New Republic wondered if the conference's "Wall Street" sponsorships led to the Congress of Industrial Organizations peculiar placement in the "catacombs" of the seminars. Depending on whom one consulted, the Congress on Education Democracy elicited a "feeling of gratification" in democracy's worth, a sign of Columbia University's impending "Anschluss with Wall Street," or a fear of education's "prostitution ... to the antidemocratic forces of America."

\footnotetext{
3 "Education Against Democracy," The Nation, August 26, 1939; "Democracy Fight Made Permanent"; "Democracy or Chatuquacy," The New Republic, August 30, 1939.
} 
Although journalists shined light on the importance of the 1939 Congress of Education for Democracy, few understood that the controversy surrounding the Congress had signified a fundamental shift in educational thought. Throughout the turbulent years of the 1930s, totalitarianism emerged in the American mind as a foreboding political system that threatened to extinguish centuries of democratic achievement. With democracy thought to be on the "brink of extinction," and with a third of the country's population under 16, Americans increasingly viewed democratic education as the "first line of defense" in stemming totalitarian aggression. ${ }^{4}$ Democratic education departed from its theoretical moorings and emerged in the American lexicon as a beacon of democratic hope and educational change. Conversations regarding democratic education soon engulfed New York's civic spaces, schools, and community centers, eliciting a populist interplay of ideas that surrounded wartime education. Two years later, the Japanese bombing of Pearl Harbor only enlarged America's democratic commitment to the schools. As debates soon flared over the school's proper role in educating for a democracy, more than just educators were brought into the fold. As Geoffrey Perrett asserts, "the entire country was drawn into the fight."

Despite democratic education's widespread popularization during World War II, most historians have conducted insular examinations of the ideology's theoretical and pedagogical underpinnings. Indeed, educational historians have "greatly ignored," "overlooked," and "glossed over" World War II. The neglect of the conflict ignores an

\footnotetext{
${ }^{4}$ Andrew Hartman, Education and the Cold War: The Battle for the American School (New York: Palgrave Macmillian, 2011), 3; Ronald Cohen, "Schooling Uncle Sam's Children: Education in the USA, 19411945" in Education and the Second World War: Studies in Schooling and Social Change, ed. Roy Lowe et al. (London: The Falmer Press, 1992), 47.

${ }^{5}$ Geoffrey Perrett, Days of Sadness: Years of Triumph: The American People, 1939-1945, Volume 1 (Madison: University of Wisconsin Press, 1985), 374
} 
era when democratic education garnered its broadest expression and attracted its widest following. ${ }^{6}$ This omission is further compounded by social histories that emphasize democratic education's role in accommodating America's war machine. Although these studies yield considerable insight about wartime curriculum, the fixation on defensecentric educational programs obscures radical changes wrought by World War II, while legitimizing sprawling claims that the conflict functioned as a conservatizing force in American schools. And while Gerard Giordano's recent work provides a more nuanced portrait of how conservatives "revolutionized the schools" during World War II, Giordano's rendering of wartime schools as a docile institution thoroughly compliant with the conservative dictums of America's "total war" marginalizes the actions of the educational community while minimizing the influence of public opinion in shaping educational policy. ${ }^{7}$

Building upon classroom and community studies by Clarence Taylor and Charles Dorn, in this chapter I argue that the popularization of democratic education opened

\footnotetext{
${ }^{6}$ O.L. Davis, "The American School Curriculum Goes to War, 1941-1945; Oversight Neglect and Discovery," Journal of Curriculum and Supervision 9, no. 2 (1993): 121; Ronald D. Cohen, "World War II and the Travail of Progressive Schooling: Gary, Indiana, 1940-1946," in Schools in Cities: Consensus and Conflict in American Educational History, ed. Ronald K. Goodenow and Diane Ravitch (New York: Holmes and Meier, 1983), 263; Alan W. Garrett, "Planning for Peace: Visions of Postwar American Education During World War II," Journal of Curriculum \& Supervision 11, no. 1 (1995): 6. For a great summary of educational historians omissions and advancements in World War II historiography, see Charles Dorn, American Education Democracy, and the Second World War (New York: Palgrave MacMillan, 2007) 4-7, 13-18. Other advancements have also recently been made in Roy Lowe, trans., Education and the Second World War: Studies in Schooling and Social Change (London: The Falmer Press,1992), which examines international trends in education during World War II, which enable historians to generate comparative approaches to the study of the history of education. Also Ronald D. Cohen, "World War II and the Travail of Progressive Schooling: Gary, Indiana, 1940-1946," in Schools in Cities: Consensus and Conflict in American Educational History, ed. Ronald K. Goodenow and Diane Ravitch (New York: Holmes and Meier, 1983) focuses on how the international conflict of World War II influenced Gary's educational policy.

${ }^{7}$ Gerard Giordano, Wartime Schools: How World War II Changed American Education (New York: Peter Lang Publishing, 2004), xix.
} 
radical new avenues for instruction, curriculum, and reform. ${ }^{8}$ Looking into New York's schools and communities, I show that these "democratic progressives" did not passively accept the pedagogical wisdom dispensed by wartime councils and committees but rather responded to war by forging a comprehensive set of educational concerns and philosophies. ${ }^{9}$

As war increasingly legitimized democratic education, democratic progressives galvanized public support for their radical initiatives by couching their ideas within the context of American democracy and wartime need. Consequently, democratic educators responded to foreign totalitarianism by positioning the World History curriculum as a democratic curricula to cultivate "citizens of the world." New programs of intercultural education found widespread acceptance as a democratic tool to combat racial tension wrought by "Hitlerite" philosophies. Teachers adhered to wartime proclamations that educators "actively participate in the communities they serve" by organizing with black communities to transform New York's schools into sites of social activism and democratic engagement. Communist members of the New York City Teachers Union strengthened their radical brand of teacher unionism and community involvement by framing their campaigns in response to wartime imperatives. Contrary to prior decades of political docility, wartime educators positioned themselves as societal "planners" and "architects," seeking to use the schools as post-war instruments to ensure peace and

\footnotetext{
${ }^{8}$ See Clarence Taylor, Reds at the Blackboard: Communism, Civil Rights, and the New York City Teachers Union (New York: Columbia University Press, 2011) and Charles Dorn, American Education, Democracy, and the Second World War.

${ }^{9}$ I use the term "democratic progressive" to address reformers who advocated for democratic education's ability to empower the nation through democratic schooling and instruction. Indeed, other reformers pursued such initiatives, while also invoking democracy for their cause. Yet, democratic progressives stood out by positioning democratic schooling, a democratization of administrative and instructional affairs, and more sustained and democratic community engagement as a resolute lynchpin of their educational initiatives.
} 
understanding. Although other historians have documented the actions of progressive educators within the schools, this renewed linkage between school and community means democratic progressives operated both within and outside established educational boundaries. Thus, the war helped galvanize democratic progressives from neighborhood, civic, labor, and educational circles, as they fought to expand the teacher's voice in instructional affairs, and empower the community's role in educational decisionmaking. ${ }^{10}$

Focusing on democratic education during World War II in New York City helps challenge the static narrative that wartime conservatives "assumed command of the schools" through pragmatic educational measures, while "confused" liberal educators wallowed in impractical educational theory unsuited to America's war effort. ${ }^{11}$ More importantly, it recalibrates a wartime scholarship whose top-down perspective has granted "little attention" to grassroots involvement that produced a "flurry of curricular innovation and community engagement" in wartime New York. ${ }^{12}$ And since educational historians have largely omitted World War II from their post-war studies, I aim to establish World War II's impact on post-war education by showing how New York's educational reformers sought to reify their wartime initiatives into the post-war

\footnotetext{
${ }^{10}$ As we will see, democratic education's popularization effectively explains why the public increasingly assigned wartime schools an expanded set of societal obligations, thereby making public education an institutional focal point for democratic, instructional, and political controversies. Furthermore, as historians continue to clarify the meaning of "progressive education," debating its coherence, genesis, and impact, I contend that the emergence of these democratic progressives helps explains the movement's murkiness and inevitable decline. Indeed, progressive education was not merely being assailed by detractors within the educational community, but was also being targeted by an ever-growing American public expecting the schools to safeguard and propagate American democracy.

${ }^{11}$ Giordano, Wartime Schools, xxi-xxiii.

${ }^{12}$ Lauri Johnson, “'Making Democracy Real': Teacher Union and Community Activism To Promote Diversity in New York City Schools, 1935-1950," Urban Education 37 (2002): 567.
} 
democratic order. ${ }^{13}$ This long term view of educational transformation helps better explain the educational "crises" of the post-war era, by revealing that Cold War anticommunism was not just a campaign to target subversion, but also a movement designed to roll back the radical educational projects that had won widespread support during World War II. The complicated emergence of democratic education during World War II illustrates that post-war schools did not emerge from the World War II with a triumphant interpretation of educational democracy, but rather with a complicated one formed by wartime experiences.

The rise of European totalitarianism throughout the 1930s aggravated fears of democracy's impending extinction. To many Americans, European totalitarianism represented the "wave of the future," a uniquely twentieth century product that combated political and economic ills with resolute action and state control. Indeed, totalitarianism's modern and technocratic vision appeared to provide efficient solutions to previously insoluble problems. This stood in stark contrast to democracy's floundering institutions and Franklin Roosevelt's fledgling New Deal. Observing the world's crumbling faith in

\footnotetext{
13 Historian O.L. Davis argues that educational historians have mostly expunged World War II from their post-war examinations, treating the conflict as a "historical marker," an element of "narrative transition," and as a "barrier" that "progressive education could not penetrate." Indeed, this omission of World War II prohibits any insight that can from a long-term view of ideological transformation, while erroneously framing post-war education as a new field with little prior history or influence. This becomes especially problematic as some of educational histories most vital works have excluded the conflict from their examinations, including post-war studies such as Joel Spring, The Sorting Machine: National Educational Policy Since 1945, (New York: McKay, 1976) Dianne Ravitch, The Troubled Crusade: American Education 1945-1980 (New York: Basic Books Publishers, 1983), along with sprawling, comprehensive studies that exclude World War II, including Lawrence Cremin, The Transformation of the School: Progressivism in American Education 1876-1957 (New York: Vintage Books, 1961); William Reese, America's Public Schools: From the Common School to "No Child Left Behind." 2nd ed. (Baltimore: John Hopkins University Press, 2011); Dianne Ravitch, Left Back: A Century of Failed School Reforms (New York: Simon \& Schuster, 2000); Joel Spring, The American School: 1642-1996. $4^{\text {th }}$ ed. (New York: The McGraw-Hill Companies Inc, 1997); Marjorie Murphy, Blackboard Unions: The AFT \& the NEA, 1900-1980 (Ithaca: Cornell University Press, 1990).
} 
popular governance, one journalist noted, "Mentally the world crisis has everywhere undermined faith in democratic institutions" and that perhaps "the political institutions associated with democracy have outlived their present usefulness." Even William Kilpatrick opined that, "American democracy is now in an extremely precarious condition - more precarious than at any time since the days of Jefferson." 14

The international conflagrations of the 1930s appeared to affirm these suspicions. In a whirlwind series of events, Nazi Germany deployed troops into the demilitarized Rhineland, Mussolini's Italy conquered Ethiopia, Spain plunged into a semi-fascist civil war, and Imperial Japan reneged on a tripartite naval accord with England and the United States. Domestically, a 1934 House investigation unearthed Nazi plots to disseminate anti-Semitic and pro-German propaganda through accepted public relations firms and more vigorous venues of political indoctrination. ${ }^{15}$ In their article "Red Fascism," Les Adler and Thomas Paterson observe how these developments led Americans to define foreign regimes by their international acts of aggression, instead of their divergent ideologies. ${ }^{16}$ Thus, public conceptions of German totalitarianism, Italian fascism, and Soviet communism became blurred together in the American mind as a singular totalitarian construct. ${ }^{17}$ This served to amplify totalitarianism's already looming menace,

\footnotetext{
${ }^{14}$ Purcell, The Crisis of Democratic Theory, 126-27, 132; William Kilpatrick, "Democracy and Respect for Personality," Progressive Education Association, Feb. 1939, 96.

${ }^{15}$ Purcell, The Crisis of Democratic Theory, 132-133.

${ }^{16}$ Les Adler and Thomas Paterson, "Red Fascism: The Merger of Nazi Germany and Soviet Russia in the American Image of Totalitarianism," The American Historical Review 75, No. 4 (1970), 1047-1048.

${ }^{17}$ Coined in Europe to describe Fascist Italy, the word "totalitarianism" failed to permeate American discourse until the spectre of international conflict spurred its usage. Thus, international acts of aggression spurred the word's injection into the American political lexicon. Indeed, many Americans viewed Fascist Italy as an interesting political experiment until the country's invasion of Ethiopia. After this invasion, the term became more generally applied to Mussolini's Italy and Hitler's Germany. Although, Communists spurned the label because of their intense disdain toward Fascism, anti-communists popularized Soviet comparisons to totalitarianism as a tool to connect aggressive similarities between Communist and fascistic governments. Two illuminating works documenting totalitarianism's semantic seepage into the American political parlance include Les Adler and Thomas Paterson, Red Fascism; John Diggins, "Flirtation with
} 
as Americans viewed international transgressions as stemming from one ideological threat. These necessary yet exaggerated fears led Americans to defensively champion virtues of democratic governance and mount urgent calls to propagate democratic principles. As political scientist Edward Purcell notes, "In the half dozen years before the United States entered the Second World War the call for an understanding and popularization of democratic 'principles' ... echoed across the country, growing louder and more insistent.” Indeed, Americans backed away from their ideological hesitations and reaffirmed their commitment to democracy as a tool to confront totalitarian ideologies. $^{18}$

Consequently, the American public looked toward the school to inspire democratic faith in a world suffused by totalitarian fear. To many Americans, public schools seemed like the only institution primed to combat a distinct brand of totalitarianism that coupled "internal political subversion with external military aggression." ${ }^{19}$ Indeed, totalitarian regimes had already channeled their schools into vehicles of propaganda and indoctrination. As Italian physician Maria Montessori noted, "Those nations which today are seeking war, have not forgotten the children and young people, they have given them positions of importance, they have organized and made of them an active social force." Montessori then called upon Americans to "take a leaf from the dictators" and turn education into an "armament on which the people can defend for security or progress." ${ }^{20}$ Another German observer noted how Nazis placed "attacks upon

Fascism: American Pragmatic Liberals and Mussolini’s Italy," American Historical Review 71:2, (Jan. 1966), 487-506.

${ }^{18}$ Purcell, The Crisis of Democratic Theory, 132.

${ }^{19}$ John Haynes, Red Scare or Red Menace: American Communism and Anti-Communism in the Cold War Era (Chicago: Ivan R. Dee, 1996), 18.

20 "Progressive Education," Progressive Education Association, May 1939, 303. 
democratic education in $1933 \ldots$ particularly on the activities program which corresponds to progressive education here." ${ }^{21}$ With two-fifths of Germany's population under thirty and a third of America's population under sixteen, Americans believed democratic education could help tip ensuing ideological battles in their favor. ${ }^{22}$ Thus, democratic education departed from its theoretical moorings and emerged as a crusading faith to inspire the young and repel totalitarian aggression.

Public education's most overt response to totalitarianism involved the schools' militaristic role in bolstering America's national defense. As the Educational Policies Commission of World War II noted, "When the schools closed on Friday 5 December (1941) they had many purposes ... When the schools opened on Monday December 8, they had one dominant purpose - complete intelligent, and enthusiastic cooperation in the war effort." ${ }^{23}$ Following the Japanese attack on Pearl Harbor, wartime conservatives ushered in a staggering array of educational transformations regarding administrative responsibilities, building usage, budgeting, and government-endorsed instructional materials. Schools also rapidly constructed wartime curriculum. High schools inaugurated technical and vocational training programs aimed at cultivating "industrial preparedness" while female students received war-related instruction in preparation for nursing and clerical posts. The War Food Administration assumed control over federal lunch programs to turn malnourished students into healthy soldiers, while physical education helped prepare boys for future military service. Milwaukee high schools

\footnotetext{
21 "Nazi Parallel Seen in Textbook Attacks, Exiled Professor Recalls Fight on Democratic Education," The New York Times, May 4, 1941.

22 "Hitlerism: A Challenge to American Education," Progressive Education Association, April. 1943, 161.

${ }^{23}$ Ronald Cohen, "Schooling Uncle Sam's Children: Education in the USA, 1941-1945," in Education and the Second World War: Studies in Schooling and Social Change, ed. Roy Lowe (London: Falmer Press, 1992) 46.
} 
emphasized courses on food rationing and clothing conservation, while Boston schools turned exercises of algebra, trigonometry, and geometry into "defense mathematics." War-themed activities cropped up in New York schools, prompting children to spell "bombardier and torpedo," and to craft compositions on the "camouflaged" abilities of zebras and grasshoppers. One high school developed a democratic system of governance, as students ran assemblies, the library, and the cafeteria. Conversely, a Long Island high school celebrated "Bill of Rights Week" by adopting a totalitarian form of school administration. Casting the principal as dictator, and teachers as arm-banded subordinates, faculty "heiled one another" while "secret students" conducted arbitrary arrests and schoolroom raids. By the days' end, the dictator crumbled under his appreciation of democracy's power and voiced a renewed faith in America as the "finest land in the world."24

New York City's public schools similarly responded to World War II by creating more nationalistic programs that furthered the war effort. One local high school created a slate of extra-curricular programs that included a Rifle Club, Radio Club, Victory Morale Squadron, and a Defense Math Club. Abraham Lincoln High School created a conservation program that collected twenty-one tons of paper, while their blood drive elicited over 100 donations. Tilden High School initiated a "Victory Books Campaign" that distributed books to soldiers, while the "Knitting for the Army and Navy" class sewed blankets, afghans, and sweaters for the war effort. Numerous schoolroom squads

\footnotetext{
${ }^{24}$ Giordano, Wartime Schools, xix; Susan Levine, School Lunch Politics: The Surprising History of America's Favorite Welfare Program (Princeton: Princeton University Press, 2008), 54-70; Ronald Cohen, "Schooling Uncle Sam's Children: Education in the USA, 1941-1945," in Education and the Second World War: Studies in Schooling and Social Change, ed. Roy Lowe (London: Falmer Press, 1992) 46-50; Geoffrey Perrett, Days of Sadness: Years of Triumph: The American People, 1939-1945 (Madison: The University of Wisconsin Press, 1973), 108-09.
} 
emerged, including "stretcher bearing and fire fighting squads," while the "Secretarial Squad," "Poster Squad," and "Honor Squad" apprised the media, the public, and fellow students of their schools' defense activities. Other schools instilled a competitive spirit between students by keeping "class charts" that kept running tallies of students "civil defense activities," and distributed "nurse-aid bandages" and "defense bonds" to victorious students. Yet another school created war-oriented classes, including physical fitness courses designed to prepare "competent commandos," "'first-aid classes" that instructed future soldiers on proper nutrition, and homefront programs that instructed students on agricultural skills and the merits of "sugar and gas rationing." Changing its school slogan from "Remember Pearl Harbor" to "Avenge Pearl Harbor," Thomas Jefferson High school raised over $\$ 100,000$ in war bonds, created "bean bag dolls" for refugee children, adapted its chemistry course to educate about "burns and antidotes for poisons," and had art students submit drawings of "pressure points, bandages, and types of poisonous snakes." Altogether, New York's schools emerged as one of the nation's most enthusiastic educational participants in support of the war effort. ${ }^{25}$

These developments reveal education's nationalistic importance in times of crisis, an emphasis that has dominated histories of American education during World War II. Yet, this narrow focus on national defense and governmental imperatives assumes the tandem of militarized schools and jingoistic curriculum typified wartime education. In addition, this view overshadows radical educational reforms associated with the democratic education wing of progressive reform under the assumption that the government either censored, muted, or overpowered more progressive educational

\footnotetext{
${ }^{25}$ A.H Lass, "War Activities in Our High Schools," High Points in the Work of the High Schools of New York City 24, (October 1942): 21-27.
} 
ideologies. The story of educational change during World War II is one in which both conservatives and democratic progressives advanced their educational agendas under the rhetoric of promoting democracy. While democratic progressives did encounter conflict in pursuing their agendas, they also found that "progressive innovations [formerly] blocked by sheer inertia and strong conservatism can now take root because the exigencies of war have weakened the opposition to them.. ${ }^{26}$ Indeed, totalitarianism's immediacy and degradation of democratic principles served to strip educational reforms of their politicized nature. Believing in the importance of "organizing in defense of democracy while we have the chance to do so," democratic progressives from previously divergent educational camps championed a variety of proposals from across the educational spectrum. ${ }^{27}$ Thus, democratic education came to represent a unifying movement, with a sheer breadth of instructional opportunities that galvanized broadbased activism and community involvement. And as the prospect of war led school officials to reach out to the public, they found communities that had already started to become democratic forums of educational thought.

The spread of the American "forum movement" in the 1930s played a key role in facilitating community-wide discussions about democracy and education. In early 1935, United States Commissioner of Education John Studebaker warned, "Unless we have a conception of the relationship of adult education to democracy ... we shall acquire a dictatorship by default." Studebaker believed that the "war-ridden, depression racked" world had become beholden to dictatorships promising "efficiency and virility" as the

\footnotetext{
${ }^{26}$ War Courses (and their implications for Peacetime), New York Teachers Guild Records, 1923-1957, box 5, Kheel Center for Labor-Management Documentation and Archives, Cornell University Library (hereafter cited as Records of New York Teachers Guild).

27 "The School's Role in Winning the War and Peace," Progressive Education Association, Oct. 1942, 300.
} 
sole way to survive. This dictatorial climate, Studebaker claimed, thrived in nations that neglected to expose their fraudulent ideologies to the educative process of democratic discussion and debate. Thus, Studebaker proposed a federally-funded "forum movement," that positioned America's patchwork of small towns and communities as “demonstration centers" where adult Americans would engage in democratic modes of discussion. Studebaker envisioned these deliberative assemblies as eliciting a complex interplay of ideas that would immunize Americans to totalitarian ideology. Ultimately, the forum movement ushered in a populist wave of democratic "government by talk," as more than four million citizens engaged in debates about contemporary issues in school rooms, civic buildings, and community centers. More notably, the forums helped popularize community-wide discourse, as they sparked informal discussion groups that revisited their conversations in women's clubs, farmers meetings, neighborhood associations, and civic organizations. Even local school administrators noted the tangible benefits of the "forum habit," as they observed Americans becoming more "wellinformed," "tolerant," and more likely to "appraise both sides of controversial issues.",28

The 1930s forum movement, overlooked in wartime histories, represented a distinct evolution in educational thought. As William Keith notes in Democracy as Discussion, nineteenth century political thought envisioned democratic institutions as "established and fixed," while the forum movement embodied Deweyan ideals that "the modes of interaction themselves are the democracy." 29 Indeed, Studebaker designed the forums to maintain their democratic integrity throughout all public interactions. First,

\footnotetext{
28 "Studebaker Warns of a Dictatorship," NY Times, June 2, 1935; "Forums Booming All Over Nation," New York Times, January 3, 1937.

${ }^{29}$ William Keith, Democracy as Discussion: Civic Education and the American Forum Movement (New York: Lexington Books, 2007), 152.
} 
Studebaker prioritized a local administration of the forums, conceiving of federal-level administration as potentially impinging upon free expression. Furthermore, he spurned the idea of avoiding political controversy and encouraged forum leaders to directly confront controversial issues. Noted examples of controversial forum panelists included speakers defending fascism, a British socialist speaking to the "Demise of Capitalism," and W.E.B. DuBois investigating issues of racial equality. In these discussions, Studebaker discouraged any sense of indoctrination, and in the Forum Planning Handbook, encouraged the public to master skills of critical thought so they could soberly evaluate "any subject."

In this sense, the forum's embrace of debate over controversial issues, which facilitated critical thought, addressed the core critiques Kilpatrick emphasized in his Social Reconstruction writings. This should come as no surprise because as a student of "Dewey protégée William Kilpatrick," Studebaker derived a tremendous influence from both progressive thinkers. ${ }^{31}$ This influence ultimately endowed the forums with a progressive orientation that was comparably radical compared to other educational institutions of the era. Unfettered by external control, the forums popularized public discourse and injected discussions of democracy, politics, and education back into America's homes and communities.

The 1930s forum movement suggested the potential impact of democratic education. Rising fear over the spread of totalitarianism in the late 1930s helped open up the schools to progressive reform movements. Although forums had the potential of changing minds and broadening worldviews, Americans came to envision wartime

\footnotetext{
${ }^{30}$ Robert Kunzman and David Tyack, "Educational Forums of the 1930s: An Experiment in Adult Civic Education," American Journal of Education 111, no. 3 (2005): 327.

${ }^{31}$ Keith, Democracy as Discussion, 263.
} 
schools as a transformative force that could accomplish a dazzling array of expectations and possibilities. Thus, the threat of war led Americans to increasingly embed their political ideals into educational visions. Describing this process, historian Andrew Hartmann notes that "as education became integral to the twentieth century American experience, it became more political. Americans with conflicting notions of the public interest . . . increasingly expressed their political aspirations in educational terms." ${ }^{" 32}$ As schools became the new "forums" of civic deliberation and public discourse, education assumed a new role in American participatory democracy. Accessible to all, public schools became "get-at-able" institutions for Americans to project, contest, or affirm their values. ${ }^{33}$ Tasked with preparing for conflict, public education became beholden to a diverse range of educational constituencies fighting to promote their own ideas of educational democracy.

Many Americans called for a curriculum that looked beyond nationalistic needs and immersed students in democratic processes. Indeed, one of the most resonant pedagogical philosophies to challenge educational boundaries was the notion that schools should help students "learn democracy" by "living democracy.” In February 1937, standing before a packed convention of 5,000 teachers hailing him as the "prophet of democratic education," Kilpatrick asserted "We cannot expect our young people to learn democracy except as they live it. If our schools are going to teach democracy, they must

\footnotetext{
${ }^{32}$ Hartmann, Education and the Cold War, 1.

${ }^{33}$ Educational historian Dianne Ravitch noted how "in times of frustration," schools emerged as "get-atable" institutions where the "power to educate" was often conflated as the "power to indoctrinate." While Ravitch applied this process to Cold War schools, I maintain this aptly named process occurred earlier, as democratic progressives mobilized the schools during World War II. For the usage of the term" get-atable," and its subsequent discussion see Dianne Ravitch, The Troubled Crusade: American Education, 1945-1980 (New York: Basic Books, 1983), 112.
} 
be run so that our young people can and will live democratically." ${ }^{34}$ Kilpatrick's notion of "living democracy" reflected a fresh interpretation of his "Project Method" that was uniquely tailored to World War II's global realities. Throughout the late 1930s American newspapers and journals vigorously documented how dictatorial regimes galvanized youth by indoctrinating students to the ideological merits of totalitarianism. This led Americans to question whether their own schools, comprised of fixed desks and a rotelike curriculum, promoted autocratic modes of thought. Furthermore, increasingly Americans came to believe that bringing communities back into the school was the best way to combat totalitarian institutions that isolated the community from their teachings.

As a result, democratic progressives championed an education that departed from conventional means of drill and instruction and engaged students in a process of "living democracy.” Inspired by Deweyan principles that Kilpatrick popularized, "living democracy" rested on the belief that critical inquiry and community involvement represented an inherently democratic process that ran counter to totalitarian instruction. Whereas totalitarian instruction was deemed compulsory and inanimate, democratic living provided lessons that could be "lived," "touched," "measured," and heard." As students participated in democratic activities, they "awakened their social conscience" to a rapidly changing wartime world in which they could proactively seek democratic solutions. Touting the benefits of this approach, the secretary of the New York State Congress of Parents and Teachers asserted "Dictators are able to mobilize men as they do machines, but only democratic education can mobilize the heart." Yet converting the oneroom schoolhouse to "live democracy" and "mobilize the heart" would prove to be a far more difficult enterprise than previously thought. As Kilpatrick already witnessed,

\footnotetext{
34 “Kilpatrick Hailed by 5,000 Teachers," New York Times, February 27, 1937.
} 
attempts to initiate democratic reform were often hamstrung by public school systems that resisted democratic impulses. It is in this way that the more autocratic nature of the "one best system" became contested, as programs of "living democracy" required a systematic reconfiguration of wartime schools. ${ }^{35}$

Meeting the instructional realities of "living democracy" necessitated the emergence of a "teacher-citizen" whose expertise was vigilantly active in both the civic and educational spheres. Indeed, to some observers it had become apparent that the war was "rapidly breaching the walls of whatever ivory towers have separated teachers from their communities." Initially coined by Kilpatrick, the teacher-citizen ideal was embraced by the public as the preeminent facilitator of school and community. The teacher-citizen was to be a democratic guide who helped students navigate their democratic experiences in daily life. Clothed in the public interest, the teacher-citizen had a "social-political" obligation to facilitate democracy inside the school, while outside the school, the teachercitizen had a "social-moral" obligation to lead active community efforts as "exemplary citizens." Previously isolated from community affairs, the teacher-citizen served as the "first line of defense" in resolving community problems that were deemed undemocratic and inimical to the nation's war effort. ${ }^{36}$ Indeed, the teacher-citizen confronted this task of educating future citizens and reconstructing a better society by being a director of discussion, an organizer of men, a scholar in his field, and a navigator of school and community. Instructing current "defenders of democracy" and future "citizens of tomorrow" required an educator who was "above-average in integrity, moral stamina, and spiritual resource." The wartime report "Teacher Education in a Democracy at War,"

\footnotetext{
35 “Democracy’s Hope Held To Be Culture," New York Times, March 28, 1936.

36 “'Speers Says Teachers Are 'Cowed,' Schools Run on Autocratic Basis, NY Times, February 5, 1944.
} 
argued that rather than succumbing to pressure, the teacher-citizen had the "responsibility to see this task, appreciate its importance, realize its difficult, accept its challenge, prepare to meet it, make all necessary sacrifices, and dedicate their every effort to its speedy accomplishment." ${ }^{37}$

In heaping herculean expectations upon the “teacher-citizen,” New York City's schools sparked a dramatic reinterpretation of educator's responsibilities. Newly formed conceptions of the teacher-citizen abounded in the New York City Public School System's (NYCPSS) wartime reports, syllabi, teacher-training manuals, and principles of curriculum development. The 1942 Report of the "Committee for the Study of Practical Democracy in Education," distributed by the NYCPSS, asserted that the main purpose of schools was to "set individuals and groups to consider problems, and during their deliberations, to practice democracy; that is, to think and to speak critically-a proceeding peculiarly abhorrent to dictatorship." According to the report, teachers should not extol democratic "words and gestures which may be full of sound and fury, signifying nothing," but rather engage in a form of directed democracy that exposed students to the social, political, and cultural institutions comprising "democratic living." Outlining how democratic living was pedagogically attainable, the report observed how one Manhattan school connected their units of study to local neighborhoods, and as students took exploratory trips to their assigned locales, they connected their "school world" to the "world outside." These activities stood in stark contrast to the insulated and more traditional approach of cultural gifts to racial issues, by encouraging students to proactively investigate racial issues in their community, while schools cooperated with

\footnotetext{
${ }^{37}$ William Kilpatrick, "The Teacher as Citizen," Frontiers of Democracy, October 15, 1942; Edward Everden, Teacher Training in a Democracy at War (Washington: American Council on Education, 1942), 5.
} 
"community organizations to overcome undemocratic practices" of racial discrimination. In its concluding section, the report noted that in these exercises, the teacher-citizen functioned as a social scientist, immersing students in the "excellent laboratory of social problems that New York City provides." ${ }^{38}$

Yet, in actively pursuing social problems the teacher-citizen confronted contemporary dilemmas associated with discussions of controversial issues. Formerly disparaged as vehicles of subversion, controversial issues were now viewed as the lynchpin of an American democratic heritage that forged social progress through discussion and debate. Indeed, one survey of Pennsylvania residents found that 64 percent of parents backed progressive education, 87 percent approved experimental school practices, and a majority in each poll overwhelmingly agreed that "teacher should be free to seek and discuss all available facts on controversial issues." Reflecting these developments, the wartime "Modern History Course of Study and Syllabus" argued that the teacher-citizen should approach controversial subjects as a democratic observer and use his "scholarly competence" to properly contextualize the social dilemmas students were expected to explore. In this way, the pursuit of controversial issues became as important as the issues themselves, as the process of inquiry and investigation endowed students with a "freedom" of "heart" and "mind" that were the "functioning of democracy." These renewed efforts in critical-thinking, the report argued, required the teacher-citizen to construct a history curriculum not fashioned around "memorization" but rather a curriculum that "grows and improves" as it rapidly responded to students'

\footnotetext{
${ }^{38}$ The Committee for the Study of Practical Democracy in Education, 8, 23-29, Folder 1, Series 175, Records of the New York City Board of Education, Municipal Archives, New York, NY (hereafter cited as Records of NYC BOE); Modern History: Course of Study and Syllabus, 13, Folder 1, Series 174, Records of NYC BOE.
} 
changing questions about their wartime world. This necessitated an academic freedom that vigilantly guarded the teacher-citizen's freedom of speech and his instructional decisions as a professional educator. Any violation of these academic liberties, according to these reports, would impinge upon a "democracy that is alive because it is equipped for growth" and schools that "neglect" and "engage in denial of democratic principles should be pushed to change their undemocratic practices."${ }^{\prime 39}$

In prompting their schools to fashion students' democratic experience around the "present struggle against totalitarianism," the NYCPSS espoused a pedagogical approach that resembled Deweyan principles associated with progressive education. But while the instructional ethos of the "teacher-citizen" embodied Dewey philosophies, the ends of this pedagogical approach were different. Whereas Dewey situated democratic experiences to make sense out of an industrialized society, the teacher-citizen viewed democratic experiences as an ideological bulwark against totalitarian subversion. Even in justifying his interpretation of "democratic living," Dewey protégée William Kilpatrick argued that "Hitlerism cannot be permanently defeated on the field of battle alone, but only in the minds and hearts of men, and especially of youth." Following the mantra that "Democratic purposes are not achieved by dictatorial methods, nor are autocratic aims furthered by democratic means," democratic progressives, knowingly or unknowingly, espoused a modernized variant of Deweyan principles that was justified by the urgent imperatives of war. Consequently, New York's teacher-citizens and democratic

\footnotetext{
${ }^{39}$ Modern History: Course of Study and Syllabus, 12-15; Curriculum Development in the Social Studies: KGN.-9B, 18-19, 22-23. Records of the NYC BOE, Folder 1,Series 174; The Committee for the Study of Practical Democracy in Education, 14.
} 
progressives fought to install their educational agendas, framing their Deweyan visions in the context of wartime imperatives. ${ }^{40}$

The development of the TU from its schism to its popularized invocations of wartime democracy, reveals the challenges of turning theoretical teacher-citizens into actual practitioners. As previously addressed, the TU's founding leadership of Abraham Lefkowitz and Henry Linville moderated their rhetoric and goals in the 1920s which ultimately helped reclaim the union's respectability and led to increases in teacher salaries and benefits. Yet, the Depression's reversal of these victories led some union members to question the contradiction of championing professional ideals in a school system that was undermining their professional status. Ultimately, these tensions over the union's lack of militancy divided the organization into two sectarian camps: "the Administration" group consisting of older, more traditional members of the TU leadership; and the "Rank and File" caucus comprised of younger, Communist-led teachers radicalized by the Great Depression. Frustrated with the militant and purportedly unprofessional behaviors of the "Rank and File," founding member Henry Linville walked out of the TU, forming the unaffiliated New York Teacher's Guild, and leaving the TU leadership to a young group of unionists emboldened by the Great Depression. ${ }^{41}$

While the root of the 1935 schism involved conflicting interpretations over "democratic unionism," a significant driver of these disputes involved divergent approaches to pedagogical philosophies. Indeed, previous studies of the TU schism stress

\footnotetext{
${ }^{40}$ Committee for the Practical Study of Democracy, 22-23, 34, 38.

${ }^{41}$ Lana Muraskin. "Professionalism and Radicalism In the New York City Teachers Union, 1927-1935. ”; Robert Iverson, The Communists and The Schools (New York: Harcourt, Brace, and Company, 1959), 1158.
} 
ideological divides over labor, while largely avoiding discussions of instructional affairs. ${ }^{42}$ This interpretation reinforces the notion that the young Communists of the Rank and File only wished to "bore from within" and assume control over the TU as a communist vehicle for labor organization. ${ }^{43}$ Although this view contains some merit, the assumption that teacher unionists separated union beliefs from their pedagogical philosophies ignores the Rank and File's desire to use the TU to help address economic and racial inequality.

Pursuing more structural changes beyond the increasing teacher salaries, the Rank and File's identification with industrial unionism ultimately led the caucus to forge a community-oriented philosophy, which viewed constituencies of "teachers, parents, and labor" as collaborative components in achieving educational change. This approach complemented the Rank and File's instructional beliefs, as teachers fused their "Marxist class analysis" with Deweyan philosophies and forged grassroots pedagogical

\footnotetext{
${ }^{42}$ Most studies tend to stress the role of labor and professionalism in leading to the $1935 \mathrm{schism}$. Stephen Cole's book, The Unionization of Teachers: A Case Study of the UFT (New York: Praeger Publishers, 1969) addresses how the union divide stemmed from differing views over union tactics and labor ideology. In Robert Iverson's The Communists and The Schools views the schism as originating from fractious disputes between Communist and Socialist factions. TU Teacher Celia Zitron's account, in Celia Zitron, The New York City Teachers Union, 1916-1964 (New York: Humanities Press, 1968), provides a brief and downplayed account of the schism, stressing the Administration's inaction towards Depression-era budget cuts, and the Rank and File's organization of unemployed and unappointed teachers as exacerbating union tensions. Marjorie Murphy's Blackboard Unions mounts perhaps the most complicated study of the schism, revealing how the union divide stemmed from a maelstrom of factors-gender, generational gaps, instructional and ideological differences, union tactics - all situated within the context of "teacher professionalism." While all these studies have merit, they have also ignored how differences over pedagogy and instructional beliefs aggravated union tensions and drew more followers to the Rank and File. Indeed, Linville and the Administration rarely addressed instruction's role in motivating the schism, yet the Rank and File attracted the more educated, and progressively trained adherents to their cause by stressing the need to bring community-minded, activist-oriented teaching to schools debilitated by budget cuts, overcrowding, lacking resources, and double-sessions.

${ }^{43}$ Robert Iverson's study, The Communists and the Schools, employs an often deterministic approach that views Communist ideology as motivating the union schism. Iverson largely viewed the "Rank and File's" aggressive approach as an extension of William Foster's Trade Union Educational League Policy, which sought to initiate a "boring from within" strategy in an effort to eventually "seize" control over unions. While this view has some merit, Iverson's account of this development ignores the complicated and dramatic transformations that marked the TU schism, as well as the swirling educational landscape of the 1930s. Iverson, The Communists and the Schools, 26-27.
} 
philosophies where the community and teacher were an "empowering agent, bringing to the masses, including students and parents, class analysis of education which rejected the potentially elitist characteristic of professionalism." Thus, the Rank and File galvanized democratic progressives by championing a militantly educational version of industrial unionism, which informed their instructional demands for community involvement and teacher's autonomy. ${ }^{44}$

In the mid-thirties, drawing on this community-oriented educational philosophy, activist members of the TU, both whites and African-Americans formed a loose coalition with democratic progressives, scholars and community advocacy associations to build support for intercultural education and school reform. ${ }^{45}$ Some of these activist members of the TU may have been Communists, who viewed participation in this coalition of liberals and leftists as an integral part of their effort to answer the Soviet-based Comintern's call for a popular front, a movement to promote coalitions of anti-Fascist organizations. ${ }^{46}$ Accordingly, American communists muffled their revolutionary rhetoric and organized in a myriad of grassroots organizations ranging from civic groups, to free speech campaigns, and crusades for racial tolerance. But communists in the TU were not

\footnotetext{
${ }^{44}$ Rank and File Group in the Teachers Union, Principles and Program, Box 74, Folder 2, Records of TUCNY; Achievements of the Rank and File, Box 74, Folder 2, Records of TUCNY; Murphy, Blackboard Unions, 154-155. Although Linville advocated democratic involvement in the unions early years, he was often reluctant to advocate for such measures after the TU weathered the anti-communist attacks of the early 1920s. Marjorie Murphy touches upon the Rank and File's frustration with Linville's "slowness" and reluctance to address prevailing issues within black schools. Murphy, Blackboard Unions, 154-158.

${ }^{45}$ Lauri Johnson, “'Making Democracy Real': Teacher Unions and Community Activism To Promote Diversity in New York City Schools, 1935-1950," Urban Education 37 (2002): 573.

${ }^{46}$ For works that stress the TU's Communist philosophy as influencing their policies and actions, see Bella Dodd, School of Darkness (New York: Kennedy, 1954); Philip Taft, United They Teach: The Story of the United Federation of Teachers (Los Angeles: Nash Publishing, 1974); and Iverson, The Communists and the Schools. For works that often absolve or downplay the union's Communist affiliations, see Celia Zitron, The New York City Teachers Union, 1916-1954 (New York: Humanities Press, 1968), Ruth Markowitz, My Daughter the Teacher: Jewish Teachers in the New York City Schools (New Brunswick: Rutgers University Press, 1993).
} 
just following Moscow's orders. They became early supports of intercultural education because they viewed the field as a vehicle for social change and democracy. ${ }^{47}$

The departure of the more conservative faction for the New York Teachers Guild enabled the TU to forge "ahead with its radical agenda." ${ }^{48}$ For example, in 1935, the TU responded to the 1935 Harlem race riot in the late 1930s by assisting the launch of the "Harlem Committee for Better Schools" to address the area's smoldering racial tensions. ${ }^{49}$ Organizing with community-wide coalitions of unionists, civic organizations, church groups, parents, and teachers, the Committee successfully advocated for the construction of new schools to mitigate overcrowding. Additionally, the committee agitated on behalf of African-Americans, as they publicized the actions of discriminatory administrators, accompanied apprehensive black parents to meetings with white school officials, and fought to expunge bigoted instructional materials propounding "black inferiority" in order to let black children "know they are people." Altogether, the TU's actions situated the schools to directly address findings of Mayor Fiorello La Guardia's riot report, which maintained that the root causes of the Harlem's social discord stemmed from educational discrimination, overcrowding, and "inadequate institutional care." Although Popular Front imperatives envisioned blacks as a revolutionary element to working-class struggle, $\mathrm{TU}$ teachers stood apart from their contemporaries by displaying a pronounced dedication to their instruction, often engaging in activities beyond the purview of Moscow-borne imperatives and union affairs. In doing so, Popular Fronters of the TU participated in civic causes that the teacher-citizen would later seek to

\footnotetext{
${ }^{47}$ Maurice Isserman, Which Side Were You On: The American Communist Party During the Second World War (Chicago: University of Illinois Press, 1993), 3-13; Hartmann, Education and the Cold War, 29-30.

${ }^{48}$ Lauri Johnson, “'Making Democracy Real," 572.

${ }^{49}$ Taylor, Reds at the Blackboard, 90-92.
} 
accomplish. As Reverend David Licorish observed of these efforts, the Communist teachers were "much more dedicated to teaching black children the way out of the crucible of American life than the teachers we have now. When they left, Harlem became a worse place. These people were dedicated to their craft." ${ }^{, 50}$

While the TU's activism constituted a distinct departure from educational tradition, it was World War II that greatly expanded the need for intercultural education, both in New York City and nationally. By the late 1930s, educators and policy-makers alike warned that the racist worldviews promulgated by Fascist regimes had already penetrated American society. Some alarmists attributed these tensions to the "suspicions" and "hatreds" diffused by the "agents of totalitarian governments." Others observed that the war exacerbated racial intolerance by unloosening periods of "passion, hysteria, and suppression" directed toward marginalized groups. Aggravating these concerns, the Social Science Institute at Fisk University tallied 242 racial incidents throughout fortyseven American cities. ${ }^{51}$ In turn, civil rights activists wantonly applied Nazi imagery to Northern Jim Crow, branding a racially contested Detroit suburb "Michigan Sudetenland," vowing to defeat "fascist forces," assailing racist "Jim Crow Uber Allies," and lamenting the Goebbel-esque "techniques" employed by citizens. As Harvard Sitkoff observed, "interracialism became an overnight fad ... Scores of liberal organizations that never before cared about the race problem awoke to the realization that they had to do something." ${ }^{, 52}$

\footnotetext{
${ }^{50}$ Mark Naison, Communists in Harlem During the Depression (Chicago: University of Illinois Press, 1983), 214-216; Cheryl Greenberg, Or Does It Explode: Black Harlem in the Great Depression (New York: Oxford University Press, 1991), 5.

${ }^{51}$ Harvard Sitkoff, "Racial Militancy and Interracial Violence in the Second World War," Journal of American History, LVIII (December, 1971), 671.

${ }^{52}$ Sitkoff, 678.
} 
In the case of American schoolchildren, reformers regarded these developments with even more concern. As early as 1938, the New York Times reported that students "reading the newspaper and having it discussed at home, are aware of the ill feeling between the Jew and the German, the Chinese and Japanese and other nationalistic groups." Indeed, students distribution of anti-Semitic literature to Jewish teachers, and etchings of racial epithets adorned upon school walls, led the Board of Education (BOE) to caution against the advance of "foreign bigotry and racial hatreds into the classroom." Furthermore, some thinkers asserted the increased frequency of "intergroup" playground clashes attested to the school's inability "to communicate America's democratic heritage." George Payne, acting Dean of New York's School of Education, warned that children faced the daily transmission of prejudice by elders within their own homes. A yearlong investigation into anti-Semitic vandals warned that children "were instigated" by street encounters with anti-Semitic orators, and racist "indoctrination" emanating from "casual comments and ordinary conversation." Professor Clyde Miller, director of the Institute of Propaganda Analysis, asserted that newspapers posed "great harm" by reporting the anti-Semitic libels of Nazi politicians without an accompanying analysis of the statements origins or "evil effects." Thus, schoolchildren appeared surrounded by swirling strands of racial prejudice at a time when America's social fabric was riven with racial antagonism. As racial discord threatened to undermine national unity, this served to strip intercultural education of its controversial connotations, and place the instruction of racial tolerance as a matter of national unity. ${ }^{53}$

\footnotetext{
53 "Educators Warn of Growing Bias," The New York Times, July 17 1938; "Interfaith Leader in Tolerance Plea," The New York Times, May 10 1941; "Schools Fight Racial Hatred," The New York Times, February 12 1939; "Anti-Semitism Report by Herlands- Calls for Tighter Control by Police," The New York Times, January 11 1944; "Racial Friction Noted," The New York Times, July 11 1943; "Schools in War on
} 
The racial tensions seemingly created by World War II ultimately popularized the nationwide creation of intercultural programs. Intercultural workshops spread across schools and universities in Oregon, New York, Massachusetts, Vermont, Illinois, and Colorado. Under the popular "Springfield Plan," the city of Springfield Massachusetts evolved into an intercultural "laboratory" that addressed racial tensions and the city's discriminatory policies. The National Association for the Advancement of Colored People recruited educators to travel the country and espouse the merits of intercultural activity. San Diego's schools created programs that addressed the racial tensions spurred by African-Americans migrations out West. By 1945, intercultural advocates received funding for the creation of two programs designed to facilitate intercultural instruction, including the College Study in Intergroup Relations at Wayne State University in Detroit and the Project in Intergroup Education in Cooperating Schools at the University of Chicago. By World War II's conclusion, the NEA boasted that almost every school district had adopted some iteration of an intercultural program. Indeed, the sheer expanse of these intercultural efforts meant that the discipline had become "politically solvent enough to be promoted by school districts and educational organizations worldwide." 54

To many observers, however, the herculean feat of eradicating racial prejudice required educators' cooperation with scholars immersed in the social sciences. In his landmark 1944 investigation of American race relations in An America Dilemma, Swedish scholar Gunnar Myrdal interpreted interracial tensions as a "problem of the heart" that could be reconciled through moral suasion and intense appeals to America's

Propaganda," The New York Times, August 6, 1939; "Prejudice Scored as Bar to Culture," The New York Times, May 14, 1939.

${ }^{54}$ Yoon Pak, "If there is a Better Intercultural Plan in any School System in America, I Do Not Know where it is": The San Diego City Schools' Intercultural Education Program, 1946-1949," Urban Education 37 (November 2002): 589-598; Burkholder, Color in the Classroom, 102-103. 
democratic creed. Often obscured in these proclamations, however, is Myrdal's claim for Americans to resolve racial tensions through the use of social scientists and the employ of "social engineering." Indeed, Myrdal observed the tendency of Northerners to be well versed in foreign affairs but to be blissfully unaware of "Negro conditions both in their own city and in the nation as a whole." ${ }^{55}$ Myrdal partially attributed this dearth of interracial knowledge to the fault of "educational offensives against racial intolerance" that neglected to go beyond the realm of "glittering generalities." ${ }^{\text {56 }}$ Consequently, Myrdal concluded his study by calling for "fact-finding and [developing] scientific theories of causal relations," which he viewed as critical for understanding and finding solutions to the racial inequality that marked American society. If anything, Myrdal believed the war was a call for the social scientist to carry out such a campaign." ${ }^{27}$

Perhaps due to his broader examination of race, or his focus on the South, Myrdal's examination neglected to note how America had already embarked on such an "educational offensive." Released by the same publisher of An American Dilemma, in the same year of Myrdal's work, and by a collaborator of the anthropologist, Hortense Powdermaker's work Probing Our Prejudices deployed social science insights to destabilize racism's development within American schools. Commissioned by the Bureau of Intercultural Education, this book sought to introduce high schools to the scientifically established findings that had previously been confined to America's colleges and universities. She effectively distilled this information for students by fashioning social science findings, statistical research, and historical observations around the narration of

\footnotetext{
${ }^{55}$ Gunnar Myrdal, An American Dilemma: The Negro Problem and Modern Democracy (New York: Harper \& Brothers Publishers, 1962), 48.

${ }^{56}$ Myrdal, An American Dilemma: The Negro Problem and Modern Democracy, 49.

${ }^{57}$ Gunnar Myrdal, An American Dilemma: The Negro Problem and Modern Democracy (New Brunswick: Transaction Publishers, 1996), II: 1023.
} 
age-accessible vignettes. Afterwards, the small book featured discussion questions where students responded to these stories, connected the narratives to their own individual experiences, and weighed in on racism's pervasiveness throughout American life. As a testament to the book's successful formula, Probing Our Prejudice was widely endorsed by educators and civic leaders in twenty-five states and became adopted throughout schools and adult interfaith adult groups across the country. ${ }^{58}$

One story that children across the country read follows an African-American child named Frank as his family escapes the South and encounters the deleterious impact of Northern Jim Crow. Upon their arrival, Frank's father consistently uproots the family as he encounters job discrimination, underemployment, and the mentality of "last hiredfirst fired." To compensate, Frank's mother supplements family wages by seeking work as a housekeeper with long hours and low wages. This instability interferes with Frank's education, as his already dilapidated black school and tenement house make it impossible to "keep up" with his classmates. Frustrated, Frank seeks the streets where he finds a similarly minded audience of youths and vandals. The narrative then follows Frank's life as he progresses from mostly innocuous acts of vandalism to the hardened life of a criminal. Padded with statistics and psychological insights, the chapter then surveys how the discriminatory acts of institutions turned Frank towards crime and away from the life of a "useful citizen." Contrasting Frank's institutional experiences with that of whites, the vignette establishes how Frank's poor performance stemmed from disparities in his social environment and not from biologically determined racial constructions. More importantly, throughout the narrative the reader sees how the more subtle mechanisms of

58 "Book on Bias Endorsed," The New York Times, October 23, 1944; Zoe Burkholder, "With Science As His Shield": Teaching Race and Culture in American Public Schools, 1900-1954, PhD dissertation, New York University 2008, 2006-10. 
Northern Jim Crow resulted in Frank's family continuing to suffer from the same poverty they experienced in the Jim Crow South. To scholars such as Myrdal, drawing these discriminatory parallels was necessary for Northerners who thought themselves enlightened when compared to their racist Southern neighbors and who also, "get shocked and shake in their conscience when they learn the facts." And as one teacher described, such lessons left students "wide-eyed by tearing down scientifically the myth of white superiority." ${ }^{\circ 9}$

Beyond revealing scientific findings, Probing Our Prejudice also encouraged students to attack the legal and social foundations underpinning discriminatory policy. In the chapter "What Can We Do About It," Powdermaker urged students to engage in action that combated prejudices, which "eat into the core of our society" and run contrary to the "essence of American democracy." The book suggested that students appoint committees to investigate active incidences of prejudice occurring in their own communities. This entailed querying "teachers, businessmen, public officials, and union leaders" in their neighborhood to find out if employers were actively engaging in job discrimination based on racial or religious criteria. Although the book asked students to reform laws to "continue with our own democratic way of life" it also noted how laws do not "prevent injustice completely." Thus, Powdermaker called for students to support social reforms through unions, churches, and the workplace in order to fulfill the "ideals" of American democracy and hopefully create new laws respected by a "new generation. ${ }^{60}$

\footnotetext{
${ }^{59}$ Hortense Powdermaker, Probing Our Prejudices: A Unit for High School Students (New York: Harper \& Brothers Publishers, 1944), 35-58.

${ }^{60}$ Powdermaker, Probing Our Prejudices, 59-74.
} 
In a wartime educational climate largely depicted as conservative and repressive, Probing Our Prejudice contained a critique of American domestic policy. As Thomas Sugrue indicated in Sweet Land of Liberty, northern civil rights activists sought to achieve racial equality by reforming "key American institutions" and by mounting intense moral appeals to the "hearts and minds of misguided whites." ${ }^{.61}$ Not only did Powdermaker attack discrimination's legal and economic roots, but Probing Our Prejudice also echoed the moral arguments of many wartime interculturalists who connected Nazi Germany's beliefs with America's racial transgressions. Powdermaker circumvented these subversive critiques by voicing an overwhelming optimism in the reformist spirit of the American ideal. To Powdermaker, America's reformist spirit, grounded in the Declaration of Independence and affirmed by America's heritage of democratic action, reinforced the nation's commitment to rectifying its anti-democratic mistakes. "Unlike the Nazi," Powdermaker noted, "we are ashamed of our prejudices and strive to diminish them." Whereas equality of opportunity pervaded American society, Powdermaker argued that Nazi Germany believed this concept of the "uniqueness of the individual" represented a dangerous concept. Thus, Powdermaker argued that students could overcome prejudice through the distinctly democratic act of cooperation, a concept that stood apart from the dictatorial nature of Nazi Germany. ${ }^{62}$

Powdermaker's work was part of a broader current of intercultural thought that legitimized its controversial expression through the application of scientific data and the invocation of American democracy. Interculturalist's connection of America's racial prejudice with Nazi racial practice actually legitimized the spread of their intercultural

\footnotetext{
${ }^{61}$ Sugrue, Sweet Land of Liberty: The Forgotten Struggle for Civil Rights in the North, xxvi.

${ }^{62}$ Powdermaker, Probing Our Prejudices, 10, 14.
} 
programs. Anticipating their critics, interculturalists argued that their program's democratic discussion of racial ideas stood in stark contrast to totalitarian regimes that masked their grievous actions and politically motivated intent. Furthermore, they claimed their programs highlighted America's democratic commitment by acknowledging contemporary and historical wrongs while identifying means to reform their nation's misdeeds. The activist impulse behind these efforts, which sent students out to investigate racial affairs in their own communities, skirted more controversial connotations that surrounded "community activism" by demonstrating the youth's commitment to democratic progress. Therefore, similar to war bonds, scrap drives, and defense work, Americans participation in intercultural programs provided yet another venue for citizens to feel involved in securing democracy and fighting Fascistic aggression. Indeed, deliberating the racial heritage of America's past, and actively confronting these problems in the present, enabled children, educators, and adults to feel as though they were on the vanguard of democratic and racial progress. And the fact that educators fashioned these lessons around scientific advances, endowed these campaigns with a more apolitical and objective bent that protected teachers from charges of schoolroom subversion. ${ }^{63}$

Couched in democratic expression and legitimized in its controversial methods through the use of scientific data, radical intercultural programs increased in wartime popularity. Starting in the late 1930s and continuing throughout World War II, New York's schools engaged in an unprecedented level of cooperation with the city's scholars, unionists, and social scientists to combat the spread of invidious prejudices throughout their school system. Initially, New York's schools relied upon the proliferation of

\footnotetext{
${ }^{63}$ Zoe Burkholder, Color in the Classroom, 141.
} 
instructional materials disseminated by activist scholars in the social sciences. Most notably, New York's schools utilized anthropologist Ruth Benedict and Gene Weltfish's pamphlet, The Races of Mankind. The pamphlet's assertion that educational opportunity, social environment, and institutional disparities had more bearing on intelligence than biological notions of race, ultimately spurred congressional investigations seeking to "expose the motive behind this book." Reflecting the progressive environment of the time, New York City's Board of Education refused to yield to political pressures and rather urged its instructional body to study the work in order to disseminate its findings throughout the city's classrooms. Yet, for New York City Superintendent John Wade, more of an effort was necessary to vanquish an enemy that sought to weaken wartime America by fomenting societal disunity:

"No longer can we afford to ignore or minimize the danger that will inevitably follow if prejudice is allowed to spread unchecked. Enemies of democracy at home and abroad neither minimize nor ignore it, but utilize every opportunity to widen the gap that exists between the racial, religious, and nationality groups in American life. Let us learn to bridge the gaps between groups an in doing defeat the enemy and strengthen democracy." ${ }^{\prime 64}$

Therefore, to Wade and other educators, utilizing "every opportunity" to palliate racial tensions necessitated the wartime deployment of all the creative and intellectual means throughout New York City. ${ }^{65}$

By reaching outside schoolhouse walls for aid and cooperation in school affairs, New York's Board of Education ushered in a fundamental departure from prior administrative practice. Previously, the centralized nature of New York's urban

\footnotetext{
64 "Queen Council on Human Relations," Folder 4, Series 562, Records of NYCBOE.

${ }^{65}$ Clarence Taylor, Reds at the Blackboard: Communism, Civil Rights, and the New York City Teachers Union (New York: Columbia University Press, 2011), 96-97; For a superb analysis of the influence of The Races of Mankind, see Zoe Burkholder, Color in the Classroom, 65-95.
} 
educational system served to isolate its schools from both community and the public. Correspondingly, the bureaucratization of New York's schools led administrators to defer to curricular "experts" in maintaining course construction and curricular affairs. In 1944, Superintendent Jacob Greenberg created the Advisory Committee on Human Relations, which brought together representatives from prominent civic, labor, and educational organizations throughout the city. The committee sought to make the inclusion of intercultural education a central priority of the entire educational system. Thus, World War II contested the Board's administrative edifice and facilitated a partial democratization of school affairs that enabled external organizations to have a voice in the intercultural curriculum. ${ }^{66}$

Alongside these democratizing changes, New York's schools engaged in one of the most tangible expansions of its intercultural program. In 1944, the Board of Superintendents expanded their slate of specialized offerings to include 250 in-service courses. With many of these offerings focusing on intercultural education, the Board projected these courses would ultimately reach 10,000 of the 35,000 educators within New York City's Public School System. These in-service courses provided a vital public service to an intercultural field undergoing consistent innovation. Idealistically, in-service courses realized Mydral's “social-engineering” proclamations by bringing modern social science insights to teachers who then conveyed this information to their students. By bridging the research gap between scholar and teacher, this ensured that city teachers

\footnotetext{
${ }^{66}$ Celia Zitron, The New York City Teachers Union: A Story of Educational and Social Commitment (New York: Humanities Press, 1968), 95.
} 
remained "professionally alert" while keeping pace with the war's rapidly evolving intercultural developments. $^{67}$

In expanding their slate of in-service offerings to include presentations by outside organizations and scholars, New York's schools also opened up their curricular efforts to the intellectual and progressive energies that animated New York's radical political landscape. New York's proximity to pace-setting universities and progressive institutions meant intercultural programs thrived off a similar cast of progressive coalitions that sought to make racial equality the instructional foundation of their teachings. Indeed, a variety of progressive, civic, and leftist coalitions and scholars dotted the roster of New York's in-service courses. Anthropologists, representatives from religious human rights organizations, and members of the Negro Labor Victory Committee and American Slav Congress gave lectures on the "outstanding minorities of the United States" and their fight to be integrated "into American life." Three members of the New York City Teachers Union (TU) delivered presentations on forging school-community intercultural contacts, while also presenting sources to find modern intercultural material. Other courses instructed teachers on propaganda analysis as a tool to assess the external variables that influence the "wrong opinion and right opinions" about other peoples. Most notably, Gene Weltfish, co-author of the controversial "Races of Mankind," gave a lecture on finding sources that reflected modern intercultural interpretations. The most popular course, sponsored by four teacher organizations and consisting of discussions led

\footnotetext{
67 "In-Service Courses for City Teachers," The New York Times, January 23, 1944.
} 
by an expert in the field, explored how to fight racial prejudice while teaching various techniques in instructing intercultural education. ${ }^{68}$

These in-service courses ultimately spread into Harlem, leading the borough's civic group, City-Wide Citizens Committee, to craft an in-service course on the "Negro in the American Scene." "With this background of authoritative and scientific data," the announcement advertised, "teachers of Negro children will be better equipped to stimulate and guide their pupils, and teachers of white children will be better prepared to function in the area of inter-racial and intercultural education." Reflecting the organizational totality of these efforts, in-service courses were hosted by teachers unions such as the TU and Teachers Guild, anthropologists from Columbia University and the University of Washington, educators in predominantly black school districts, members of the National Committee to Combat Anti-Semitism, the American Commission of Jewish Writers, Artists, and Scientists, news commentators, director of the Service Bureau for Intercultural Education, high school administrators, and representatives from the American Museum of National History. Altogether, these in-service courses reflected a culmination of the city's activist and intellectual spirit in order in order to confront the fascist energies weakening America's national unity. In this sense, intercultural education represented a decidedly local response to international acts of aggression. ${ }^{69}$

Wartime intercultural programs did not just address anti-semitism and racial discrimination. Advocates of intercultural education were also concerned about future postwar international tensions and endorsed the study of world affairs, which included studying about the history and culture of the Soviet Union. Historians documenting

\footnotetext{
68 "Board of Education Inservice Credit Course For All Teachers," Folder 1, Series 634, Records of NYCBOE.

${ }^{69}$ Ibid.
} 
intercultural education have tended to craft more insular studies of its domestic campaigns while largely excluding the movement's increasingly globalized focus. This has tended to portray intercultural education as a defensive movement defined by the reactionary postures of what the program opposed, rather than the principles that the movement endorsed. Indeed, interculturalists moved beyond combating racial tensions at home by looking to ameliorate international tensions that threatened to aggravate future conflict abroad. By 1944, many reformers cautioned that the yawning ideological gap between Russia and the United States threatened to polarize diplomatic relations after the war's conclusion. Thus, interculturalists sought to present a scholarly evaluation of the Soviet regime while creating a more humanized portrait of the Russian people detached from their often sensationalized and totalitarian associations. Watching one or even two generations of their students marching off to war ultimately intensified educators' urgency for these campaigns, which they saw as forming a foundational "basis of world peace." 70

Starting in 1944, and continuing into the early years of the post-war period, New York's Board of Education approved the creation of in-service courses that explored the policies of the Soviet government and the culture of the Russian people. In the dawn of the post-war years, many educators lamented how instructional materials regarding world cultures either remained lacking in number or flawed in interpretation. Consequently, New York's Board of Education brokered in-service courses with the American Russian Institute (ARI), an independent, locally incorporated program connected to the top Russian scholars in America. Employing professors from New York University, Columbia University, as well as fellows of the Russian Institute and writers on Soviet

70 "Unity in Education Urged for World," The New York Times, January 20, 1944. 
government, the ARI sought to demystify the "post-war roles" of the United States and Soviet Union by bringing "facts" to the American people. This approach involved closing "informational gaps" by providing a diversity of accurate and innovative material regarding Russian history, demography, literature, geography, educational practices, and governmental policy. "Whether one regards this colossal neighbor as the hope of the world, the greatest menace to our way of life, or just as something to get along with," one ARI brochure advertised, "it's important." 71

Perhaps as a testament to the ARI's controversial nature, the Board subjected the institute's lectures to a more stringent process of administrative supervision. As a caveat to his endorsement, Superintendent Frederic Ernest declared that Russian in-service courses necessitated an "extremely competent observer at each lecture" who documented instances of "obvious bias" and any attempt to stifle "free discussion." In one report that observed John Marsulka's lecture on "Economic Organization of the Soviet Union and Economic Planning in the Soviet Union," observer Anastatia Knight noted that Marsulka's assessment of Russia's Five Year Plan included a sound presentation that emphasized the facts while also elaborating upon the ideology and methodology driving his conclusions. She made distinct mention of specific literature Marsulka suggested, and documented that he accompanied his editorial departures with "recognized honesty" and "straightforward statements." Appraising the audience as "not too articulate," Knight also highlighted how one woman rose to contest Marsulka's characterization of a Russia as a "police state." Concluding that the woman "was hardly a teacher because of her pronounced accent," Knight observed how Marsulka dealt with the dissenter with such

\footnotetext{
71 "The American Russian Institute," Folder 9, Series 634, Records of the NYCBOE.
} 
authoritative swiftness that the woman left the presentation. Altogether, Knight indicated she "thoroughly enjoyed the lecture." 72

Bolstered by creative in-service programs and with the support of New York City school officials enthusiastic about expanding "democratic procedures in the classroom," intercultural education projects spread throughout the New York City school system. ${ }^{73}$ At Public School (P.S.) 174 in Brooklyn, one school demonstrated how intercultural education could emulate the cultural focus of Rachel Dubois's cultural gifts movement while framing their examinations to address war-related issues. Learning about the Jewish "struggle against tyranny and for freedom," students explored "Hebrew songs and Negro spirituals" to address contemporary instances of Anti-Semitism, which represented the most "pressing social disorders of the day." In addressing these "social disturbances" in a studious and "scientific manner," students experienced the "trill of accomplishment" as they addressed the factors aggravating national disunity by proving a "solution." 74

In another instance, Harlem schools and communities mobilized the "machinery of society" to address the racial tensions and economic issues pervading wartime Harlem. Seeking to use the schools to "mitigate" these issues, the "Living Together Program" tasked students to "participate in all parts of school life in order to improve selfexpression and emotional growth." Consequently, students worked on essays addressing black achievement and created theatrical productions that contested the myths of racial

\footnotetext{
${ }^{72}$ Report on the Fifth Lecture of the American Russian Institute, Folder 9, Series 634, Records of the NYCBOE.

73 “Democracy Sought in Schools' Work," The New York Times, April 25, 1943.

${ }^{74}$ City of New York Department of Investigation. Report to Honorable F. H. La Guardia on the Administration of human Relations Program in New York City Schools. New York, 1945, 74.
} 
superiority. Schools also addressed discrimination by utilizing modern "audio-visual aids," appointing school psychologists to discuss intercultural films, while students planned to hold after-school films sessions where "children with prejudices" viewed and discussed Human Relations films. "Living Together" also spawned an experimental twoyear program called the "Harlem Project," which mobilized community parents into "Parents 'Do' Programs" and block committees. Acknowledging that neighborhood issues could not be "solved by the school system alone," these programs sought to "marshal community forces behind a joint program" that sought to address the "socioeconomic" issues pertaining to "Harlem problems."

Throughout a variety of schools, students also witnessed their more traditional courses develop into modernized classes that tailored issues of race around wartime events. In a mathematics class at Mark Twain Junior High School in Brooklyn, students mapped the results of Army intelligence tests in order to prove that "given equal educational and economic opportunities, one race does just about as well as any other." Students also attended language classes that "exploded the myth of a pure Aryan language," while social studies courses integrated "Races of Mankind" into regular curriculum in order to use history to contest "un-American discrimination and intolerance." Similarly, at DeWitt Clinton High School in the Bronx, science classes assessed the scientific claims advanced by the "Races of Mankind," and used the pamphlet to discuss the meaning of race, and have students discuss if people were "more advanced than others because of their biological characteristics." At William Taft High School, students also compiled an "Anthology of Brotherhood of Poetry," which

\footnotetext{
${ }^{75}$ City of New York Department of Investigation. Report to Honorable F. H. La Guardia on the Administration of human Relations Program in New York City Schools. New York, 1945, 75.
} 
impressed numerous parents who requested copies for their "business associates." And at P.S. 3 in Queens, an all-white school, students explored Indian "struggle for freedom" against colonial rule, which provided a teachable moment for educators to discuss myths of racial inferiority while also clearing up "pupil misconceptions about Negroes." The intercultural slant of these classes ultimately realized Administrative Assistant Dr. Jon King's vision of an intercultural education where the field was not just "a new subject introduced into the curriculum," but rather a part "of every school subject and every school experience. ${ }^{76}$

New York's schools and teachers also tirelessly worked to incorporate modern materials and approaches to the teaching of intercultural education. Films such as "Common Cause" and "Challenge to Democracy" explored the racial ideology and travails of peoples, areas, and nations affected by World War II. Radio programs such as "Blueprints for Peace," broadcasted panel discussions for students to learn about the United Nations Charter and its impacts to "world peace and necessary to Human Relations." In 1944, the Board of Superintendents published "Museums, Libraries, Parks, Zoos and Gardens as Education Resources," which sought to alert students and educators to archives and cultural collections pertinent to continued exploration of intercultural education beyond the classroom. Yet, the educational benefit went beyond simply viewing these films. New York City teachers also created activities that corresponded to these modern films, which allowed classrooms to turn into post-viewing forums and activity centers where students could translate the lessons from these modern materials into practice. Schools also used the allure of modern films to create "joint school

\footnotetext{
${ }^{76}$ City of New York Department of Investigation. Report to Honorable F. H. La Guardia on the Administration of human Relations Program in New York City Schools. New York, 1945, 72, 85-88.
} 
community-programs," where parents and community members came to watch the films and hear the views of a "prominent neighborhood persons" on the topic of interest. ${ }^{77}$

The New York City Public School System ultimately illustrated the wartime urgency and priority of these intercultural campaigns by engaging in frequent evaluations and studies of their newfound programs. In a study of 434 anonymous students, 361 students indicated they had attempted to confront the prejudiced views of others, 262 espoused a belief In racial tolerance, 48 pupils joined organizations attempting to ameliorate racial tensions, while 103 students attended lectures, mass meetings, or intercultural exhibits. One student surveyed indicated that the intercultural training "helped me see a dangerous precipice in the thinking of a member of my family," while another indicated "prejudice and discrimination in the minds of young people originate at home. If you are judging from class discussions and contact with the boys, I feel assured in saying that considerable success was achieved." ${ }^{78}$

The City of New York Department of Investigation also commissioned a 1945 investigation that surveyed the efficacy of the school's Human Relations and intercultural programs. "We have amassed a great deal of material, and, although we have only scratched the surface," the investigation indicated, "there is apparent the dynamic evolution of worthwhile human relations program in New York City's schools." Among the reports findings were numerous articles authored by New York City Teachers that received widespread distribution and acclaim. These included articles that blasted "racial myths," gave a "scientific treatment" of the origins of racial attitudes, explored how

\footnotetext{
${ }^{77}$ City of New York Department of Investigation. Report to Honorable F. H. La Guardia on the Administration of human Relations Program in New York City Schools. New York, 1945, 91-94.

${ }^{78}$ City of New York Department of Investigation. Report to Honorable F. H. La Guardia on the Administration of human Relations Program in New York City Schools. New York, 1945, 78.
} 
racial equality could be explored through a biological lens, and illustrated how racism created "a destruction of the foundations of American democracy." While the report indicated that Human Relations Programs grew out of the support of school officials, it also noted that the support from teachers and the community meant these initiatives also functioned as a "grassroots movement" mobilizing in "response to local needs."79

Building off the wartime enthusiasm surrounding intercultural education, the TU assumed the posture of the "teacher-citizen," and rebranded its intercultural programs as a democratic salvo aimed at obliterating the racial discord undermining America's national unity. Historian Robert Shaffer notes its active support of all phases of the war effort "gave them perhaps more credibility and influence when they pushed for the expansion of intercultural education programs in New York City schools." ${ }^{" 80}$ Indeed, the $\mathrm{TU}$ and its allies viewed intercultural education almost as a panacea to address racial tension on the homefront. Throughout the 1930s and 1940s, southern blacks migrated to New York and encountered a confluence of poverty and racial discrimination characterized by high rents a scarcity of housing, and occupational discrimination. ${ }^{81}$ Educational reformers took note of the "educational implications" of these developments, arguing that wartime schools needed to address the inequities and antagonisms Northern Jim Crow created ${ }^{82}$ A 1943 Harlem riot compounded these racial tensions, as thousands of blacks clashed with police officers over a rumor that a white officers had killed a black soldier. As Thomas Sugrue indicated "the black and white press alike denounced

\footnotetext{
${ }^{79}$ City of New York Department of Investigation. Report to Honorable F. H. La Guardia on the Administration of human Relations Program in New York City Schools. New York, 1945, 70-71. ${ }^{80}$ Robert Shaffer, "Multicultural Education in New York City During World War II," New York History (July 1996): 308.

${ }^{81}$ Greenberg, Or Does it Explode, 222-223.

${ }^{82}$ Leonard Covello, "A Community-Centered School and the Problem of Housing," Educational Forum 7, (January 1943): 135.
} 
Harlem's 'hoodlums,' but most civil rights activists and black writers put the event into the context of simmering wartime discontent. ${ }^{\prime 83}$ Even internationally, the spread of racial intolerance during World War II also threatened America's global claims of democratic purity. Responding to the lynching of 28 year old Cleo Right in Missouri, Hitler's Berlin radio touted the hanging as "evidence" of what awaited America's African allies in the event of a "victory of the democracies." 84

Responding to these developments, union members brought intercultural education from the margins to the mainstream by framing racism as "anti-American" and casting racists as "Nazi" agents. ${ }^{85}$ The union contended that "people who preach hatred against Catholics, Negroes, Jews or other minority elements are attempting to divide and weaken us." Furthermore, the TU argued that deepening racial divisions compromised international efforts that contrasted the egalitarianism of American democracy with acts of German fascism. In doing so, the TU galvanized fellow democratic-progressives to join their campaigns, while luring reticent Americans to embrace the elimination of racism by virtue of wartime expedience. Thus, the TU constructed a diverse and significant array of solutions to heal racial divisions in a nation seeking wartime unity. ${ }^{86}$

The TU's close association with scholars on the vanguard of racial thinking led the union to forge thoroughly distinct campaigns for racial tolerance and civil rights. The close scholar-teacher associations promoted by the TU avoided intercultural

\footnotetext{
${ }^{83}$ Sugrue, Sweet Land of Liberty, 68-69.

${ }^{84}$ Hitler's Radio Gloats over Missouri Lynching," Daily Worker, February 2, 1942.

85، "Schools in War on Propaganda," The New York Times, August 6, 1939; "Schools Fight Racial Hatred," The New York Times, February 12, 1939; Selig, Americans All: The Cultural Gifts Movement, 16.

${ }^{86}$ Throughout the wartime years, the TU increasingly cast acts they deemed as steeped in repression, bigotry, or anti-Semitism as stemming from "Nazi" or "Fascistic" Behaviors. This language pervaded the union materials and newspaper, with its most noted study being its report on "Fascism in The New York City Public Schools," which vigorously documented "Fascistic" behavior throughout New York's schools and communities.; "Fascism in The New York City Public Schools," Box 2, Folder 3, Records of TUCNY.
} 
intermediaries, such as Rachel Dubois, who often adulterated the more controversial findings of social science research to make it more fit for schoolroom consumption. Shorn free from the administrative and intellectual mechanisms that previously homogenized the movement, intercultural education now advanced a diverse array of racial campaigns that reverberated throughout New York's schools and classrooms. Representing the benefits of this approach, TU intercultural material commonly included the writings of Howard University Educational professor Doxey Wilkerson, who argued that the economic fate of New York's African-Americans was predominantly linked to a "caste philosophy" that was reflected in the city's schools and curriculum. To Wilkerson, black students experienced a "mental crucifixion" as they were often denied classes in "cultural education" and relegated to courses in manual training or vocational education. Wilkerson linked these conditions to a "furtherance of fascism in America," as black students were subjugated to a bifurcated system of schooling, where their "basis of racial origins" dictated their limited educational opportunities, thereby determining their “inferior” social rank. Indeed, Wilkerson's scholarly philosophies reflected larger educational concerns about anti-democratic practices creating fascist attitudes. In a 1937 speech, Kilpatrick warned that education must confront America's "social-economic situation," lest some "American Hitler will start an American youth movement." The Progressive Education Association similarly observed that "the worst Negro shack in Georgia is as much a symbol of this democracy as the clean granite shaft of the Washington monument," and that "our own race relations with one race is a measure of our right to criticize a dictator who has shamed his country in the treatment of another race. $\$ 87$

${ }^{87}$ Burkholder, Color in the Classroom, 4-5; Clarence Taylor, Reds at the Blackboard: Communism, Civil 
The TU built off these wartime tensions and scholarly findings by constructing new programs that linked civil rights to educational opportunity. Whereas the cultural gifts movement avoided political advocacy, and the exploration of economic, political, and social inequalities, the TU's efforts directly linked African-American's educational opportunity to larger examples of discriminatory policies and institutional failings. In their 1939 conference, the TU charged that the denial of "minority rights" in New York's schools was a direct violation of the guarantees codified in the Declaration of Independence and the fourteen amendment of the Constitution. Mirroring Studebaker's philosophies, the TU sponsored a 1939 forum entitled "Has the Negro Youth a Chance," where representatives from welfare councils, labor organizations, schools and cultural associations discussed the structural forces inhibiting the development of AfricanAmericans in economic, political, and educational life. The forum concluded with the union highlighting that scholars had "blasted" the whole theory of racial inferiority, and that the TU should call for a practical application of these findings to pervade all affairs of educational policy. ${ }^{88}$

After the annual conference, the TU organized in communities and promoted activities that publicized the racial disparities in schools and municipal services. TU teacher Mildred Flacks co-founded the Bedford Stuyvesant Neighborhood Council (BSNC) devoted to obtaining better schools, community resources, healthcare centers, and more playgrounds. BSNC delegations and residential surveys spearheaded by Flacks ultimately achieved the construction of low-cost housing projects and child care centers.

Rights, and the New York City Teachers Union (New York: Columbia University Press, 2011), 77-81; "Kilpatrick Hailed by 5,000 Teachers"; "The South: Its Land, and Its People," Progressive Education Association Journal, October 1941, 291.

88 Third Annual Educational Conference of the Teachers Union Local, "Education for Democracy, 1939," Box 46, Folder 9, Records of TUCNY. 
On November 14, 1945, Flacks, serving as the TU's spokeswomen, presented the surveys findings on the prevailing conditions ailing Bedford-Stuyvesant schools, resulting in the construction of four additional school buildings. In other campaigns, the union ventured beyond the schools, documenting the pronounced racial disparities in neighborhood health services, and arguing for the importance of full-fledged programs "in under-privileged communities such as Harlem, the Lower East Side and other such communities." In a high profile showdown, the Hillburn, New York, Board of Education rezoned its district to assign fifty-six black students to "decrepit, segregated shacks" functioning as classrooms. As parents refused to send their children to these makeshift schools, the TU publicized the confrontation, lauding the parents actions, documenting the school's intransigence, and branding the situation "Jim Crow North." Historian Clarence Taylor observed the skillful nature of these campaigns, as they indirectly accused New York's schools of neglect, while couching racial disparities in terms of war preparation where a "strong democracy must assure all its citizens the same care and services.” In doing so, teacher-citizens echoed larger concerns over national security, that linked nutrition, public health, and welfare to war-time matters of national defense. And in a progressive sense, teacher-citizens directly addressed Dewey's assertion that racial attitudes were linked to structural and material forces. ${ }^{89}$

The TU's close association with anthropologist Franz Boas also placed the union's intercultural campaigns within a more scientific framework that helped complicate their schoolroom presentations of race. In his capacity as an anthropologist,

\footnotetext{
${ }^{89}$ Third Annual Educational Conference of the Teachers Union Local, "Education for Democracy, 1939," New York City Teachers Union Records, Box 46, Folder 9, Records of TUCNY; Taylor, Reds at the Blackboard, 79-80, 84-85; Susan Levine, The Surprising History of America's Favorite Welfare Program (Princeton: Princeton University Press, 2008), 54.
} 
Boaz argued against notions of black inferiority by asserting that racial differences stemmed from cultural orientation instead of biological notions of race. These ideas ultimately exerted an enormous influence over social science, as Boas played a key role in shaping popularized understandings of race, environment, and culture. With the world dominated by racialized philosophies, Boaz concentrated his scientific efforts on public schools, which he envisioned as playing a key role in constructing popular perceptions of race. Most importantly, Boaz sought to rectify flagrantly bigoted teachings throughout American schools, as he asserted, "In Germany today, even the scientist can teach only those things which agree with Hitler's ignorant prejudices. There is no excuse, however, for ignorance or prejudice in our educational world, which is free to teach the truth.”

In focusing on schools, Boas asserted that proper teachings of racial relations should represent a layered and complicated understanding of the economic, historical, and social conditions that created the conditions of racial groups. This involved teachers critically addressing "controversial issues" that exposed American's historical acts of discrimination. Speaking at the 1940 TU Conference "Education for Democracy," Franz Boaz chaired a panel on "Schools for Tolerance," and outlined his ideas while affirming the necessity of academic freedom to teach an unrestricted view of race in American affairs. More vigilant protections for educators in the classroom, Boaz claimed, would free teachers to instruct a more realized course that not only tries to "influence the children," but also influences "their whole environment."

At the same conference, the union addressed how one TU member helped his school ameliorate racial tensions by using an approach that drew on Boas' ideals. To

\footnotetext{
${ }^{90}$ Burkholder, Color in the Classroom, 3, 44-56; Selig, Americans All, 24; Fourth Annual Educational Conference Sponsored by the Teachers Union, "Education for Democracy, 1940," Box 46, Folder 5 , Records of NYCTU.
} 
cope with interracial clashes that constituted "racial dynamite," the school created a "East Harlem Committee for Racial Cooperation," comprised of faculty, students, and local residents. Ultimately, the committee enlisted the help of community agencies, provided students with the "factual ammunition necessary to combat jingoistic propaganda," and provided students with genuine social "experiences" where they could apply their newfound attitudes. In this experimental war oriented program, students learned of the biological similarities between whites and blacks in science, explored the economic symptoms of discrimination in history, and studied contemporary accounts of bigotry in newspapers, magazines, and radios. These activities reflected the suggestions of contemporary observers, who asserted that schools should instruct students to vigilantly diagnose "Hitlerite" propaganda that purportedly pervaded American media. Throughout this process, students were given materials where they were asked to critically link their scholarly findings to their external observances in schools and communities. At the end of the program, educators noticed a profound shift in student racial attitudes, pointing to extensive questionnaires, which required students to critically demonstrate their "acquisition" of intercultural knowledge. Although teachers acknowledged that students may have "indicated the answers faculty expected them to make," these assessments were positive enough that teachers recommended that the programs continue to serve as a model for wartime development. ${ }^{91}$

The union followed up its conference with the creation of the Franz Boas Workshop, which was dedicated to Boaz who died in 1942. Many attributed his death to his intense anti-Nazi activities and campaigning. The workshop involved crafting courses

\footnotetext{
${ }^{91}$ Fourth Annual Educational Conference Sponsored by the Teachers Union, "Education for Democracy," 1940.
} 
and curriculum for fellow staff, parents, and civil organizations. Similarly, the workshop spearheaded forums on racial issues and also functioned as an oversight committee to identify biased materials to suggest for revision or removal from school curriculum. Indeed, these workshops served a vital purpose. First, they provided a scholarly bridge that helped distill complicated social research findings into accessible activities for teachers to understand and apply in their own classrooms. Also, educators attempting to integrate intercultural materials into their classrooms had relied upon instructional materials filled with outmoded interpretations. This push for new materials was especially important as many critics contended that older intercultural materials espoused the same narrowed focus on ethnic stereotypes that fueled the racial ideologies of the Third Reich. Consequently, the Franz Boas Workshop served as a "clearinghouse" for intercultural materials that distributed helpful information to universities and high schools, while prohibiting harmful ideas from reaching the classroom. Although the workshop was not officially recognized by the Board of Education, it did serve as a vital presence in disseminating instructional materials influenced by the most modern social science methods and findings. ${ }^{92}$

As the TU's efforts gained more momentum, the union was not just content with workshops, but also vigorously lobbied to help shape New York's official curriculum. The TU argued that BOE curriculum, drafted by internal "experts" and policymakers, was created by an autocratic process rather than a democratic process that included teachers and other stakeholders. Thus, the TU initiated its campaign for a more "democratic administration" and cited William Kilpatrick who argued "It seems a strange

\footnotetext{
92 Taylor, Reds at the Blackboard, 95; “Tolerance Study Will Be Expanded," The New York Times, March 23, 1944; "Schools in War on Propaganda."
} 
contradiction that the United States of America, with its emphasis on democracy, should have developed a school system which is administered upon a pattern diametrically opposed to democracy." ${ }^{93}$ Ultimately, the TU framed its campaign in response to the war effort and argued that all institutions of "American democracy" must reassess their administrative structure in order to meet the "great challenge to our survival." The TU proposed an educational "Bill of Rights" for teachers that included giving teachers the right to present items for discussion at conferences, the right to speak freely in professional affairs, and the right to use administrative distribution tools such as letterboxes and bulletin boards to advertise workshops and resources. The union also lobbied for a democratic administration of the school and for "democratically elected "teachers councils" that would have a strong voice in curricular affairs. To learn more about the extent of democracy at the grassroots, the Teachers Union ultimately distributed questionnaires where teachers evaluated how "successful they were" in "securing greater democracy" in their schools. ${ }^{94}$

In response to these and other campaigns, New York's Board of Education endorsed more democratic practices in administration and curricular affairs. The New York Times indicated "'for the first time," classroom teachers had the opportunity to participate in conferences and course development in order to keep "curriculum abreast of the changing needs of the students," while also stressing "the place of democracy in the lives of the students." With New York City's 1,100,000 students and 38000 teachers offering a "fertile field for experimentation," these plans ultimately sought to create a

\footnotetext{
${ }^{93}$ Third Annual Educational Conference Sponsored by the Teachers Union, "Education for Democracy, 1939," Box 46, Folder 5, Records of the New York City Teachers Union,

94 "A Program for Achieving Democracy in Our School System," Box 55, Folder 3, Records of the New York City Teachers Union,; "Questionnaire on Democracy in the Schools," Box 55, Folder 3, Records of the New York City Teachers Union.
} 
"better school program for New York City's army of boys and girls." 95 Ultimately, the BOE approved a significant amount of intercultural in-service courses, while endorsing new initiatives that enabled externally approved courses to be taught by outside groups and civic organizations. This ultimately opened the door for the TU, as the union instituted intercultural in-service courses taught by scholars and union teachers who reported success in incorporating intercultural material. ${ }^{96}$ These efforts helped bring more open discussions of racial relations into the New York City schools. As noted sociologist Gunnar Myrdal asserted, “an educational offensive against racial intolerance going deeper than the reiteration of the 'glittering generalities' in the nation's political creed has never been seriously attempted in America." Yet, the TU appeared to be promoting such a feat. ${ }^{97}$

Beyond their participation in curriculum, textbook oversight, and community activism, the TU also targeted the teaching practices of bigoted teachers, who they branded as flagrantly un-American. In 1942 civics teacher May Quinn used an antiSemitic leaflet in her class for a civics lesson. In subsequent lessons Quinn called Italian children "greasy foreigners," praised Mussolini, and stated Hitler has done some good for Germany." 98 After Quinn asked a teacher "where she could get a copy of the Talmud so that she could see where it said that Jewish men may rape Christian girls over the age of three," fourteen teachers signed a statement listing the teacher's comments and

\footnotetext{
95 “Curricula Face Broad Revision in City Schools," The New York Times, June 29, 1941.

${ }^{96}$ Celia Zitron, The New York City Teachers Union 1916-1964 (New York: Humanities Press, 1964),155; "In-Service Courses for City Teachers," The New York Times, January 23, 1944; "Standards for Approval of Alertness for In-Service Credit Courses for Teachers," 1939. Box 1, Folder 3, Records of the New York Teachers Guild.

${ }^{97}$ Gunnar Myrdal, An American Dilemma, 48.

${ }^{98}$ Bigotry in the New York City School System, Box 9, Folder 8. Records of the New York City Teachers Union.
} 
complaining Quinn engaged in "intolerance" and "un-Americanism." 999 Upping the ante, the TU branded May Quinn as participating in flagrantly "anti-American acts" and argued that Quinn's teachings constituted a direct breach of national security by undermining the country's patriotic unity. Eventually winning the support of dozens of labor, civic, and grassroots organizations, the TU's efforts helped spur Quinn's dismissal. Although Quinn was ultimately reinstated, the instance served as remarkable evidence of the TU's organizational prowess and their commitment to democratic values.

Furthermore, the union's early support on an issue that eventually culminated into a "city-wide controversy" established the TU as a wartime authority on intercultural affairs, and increasingly won the embrace of democratic progressives inside the schools and outside in New York's communities and neighborhoods. ${ }^{100}$

The entirety of these intercultural campaigns, especially including efforts to spur Quinn's dismissal, led democratic progressives to gain valuable inroads into wartime schools, while also forging democratic coalitions with the community. Despite this fact, educational historians have largely neglected to explore the widespread acceptance of intercultural education during World War II. ${ }^{101}$ Other studies reinforce the erroneously conservative portrayal of wartime schools by depicting wartime programs as strictly focused on cultivating goodwill and tolerance. Yet, the exigencies of World War II facilitated a curriculum that aggressively attempted to reconcile the racial divides coursing throughout New York's schools and neighborhoods. Under the glare of fascism,

\footnotetext{
${ }^{99}$ Joshua Freeman, Working Class New York: Life and Labor Since World War II (New York: New York Press, 2000), 73.

${ }^{100}$ Taylor, Reds at the Blackboard, 75-76

${ }^{101}$ The most noted works that illustrate how social science research fueled more critical intercultural teachings are Burkholder, Color in the Classroom and Clarence Taylor, Reds at the Blackboard, 75-99. Although Dianne Selig's, Americans All, addresses the role of World War II in influencing intercultural thought, her study is largely concerned with Rachel DuBois' activities of the 1920s and 1930s.
} 
Americans were asked to assess how their own prejudices activated anti-democratic processes threatening to divide America's national unity. Indeed, the TU's pairing of Popular Front imperatives with teacher-citizen philosophies created one of the most radical schoolroom approaches to intercultural education during the twentieth century. The war's increasing legitimization of intercultural education and civil rights ultimately secured TU support from grassroots campaigns, civil right activists, religious leaders, and civic organizations. These coalitions helped sustain the TU especially in times of political conflict.

The energy and community support behind the TU's programs did not mean the union was impervious to attack. Nor did it mean that the union functioned within a limitless frontier of academic freedom. Indeed, taking place at the same time as the TU was advocating a more democratic and inclusive approach to education, was an anticommunist investigation that threatened to curb the union's influence. Originally conceived as a commission to investigate the financial conditions of New York's schools and universities, by 1941 the Rapp-Coudert Committee had adopted the tenor of an anticommunist investigation. Indeed, the committee pioneered an investigatory form of stagecraft where they conducted information gathering in closed-door meetings, while revealing their findings, and the testimony of "friendly" witnesses, in public hearings. Ultimately, these hearings resulted in the forced dismissal or resignation of over fifty educators, predominantly concentrated within New York's city universities. Among the anti-communist casualties was Dr. Max Yergan, the first black faculty member in New York's public college and a collaborator with the TU on "Negro History" lectures and inservice courses. Yergan had previously won acclaim for his progressive approach to 
"Negro History," which explored African-Americans within a global context, while exposing the "forces" that influenced their "present status" in America." Ultimately, informers at Yergan's hearing described the instructor's world-mindedness and sociopolitical approach as "liberal and progressive," and Yergan was denied reappointment. Thus, anti-Communism appeared to be subverting academic freedom in New York's educational system. ${ }^{102}$

The historical view of the Rapp-Coudert Committee as a conservative victory, however, merits a re-examination. Historically, the Rapp-Coudert Committee inhabits a peculiar chronological paradox, where its foremost successes are attributed to its anticommunist victories in 1941, and its influence on anti-communist investigations of the postwar era. Commonly described as a "dress rehearsal" for McCarthyism, the committee's wartime legacy is largely known for providing an investigatory blueprint for subsequent Cold War investigations. Other studies have noted how the investigators assembled records of subversive activities that would "become crucial" in later anticommunist campaigns of the 1950s. Andrew Hartmann observed how the committee "anticipated the larger red scare" by firing teachers not for actual political activity, but rather through activity that was deemed "conduct unbecoming." And Marjorie Murphy noted how the "stormy history of Local 5, targeted in the Rapp-Coudert hearings and expelled from the AFT in 1940, was an issue ready to be exploited" in later Cold War investigations. Yet, demarcating the committee's influence only in its immediate and long-term aftermath while disavowing the decade of time in-between, makes it easier to portray Rapp-Coudert as a distinctly conservative victory. Most of these studies rarely

\footnotetext{
102 "The Struggle For Free Speech at CCNY, 1931-1942," Virtual New York City, http://www.vny.cuny.edu/gutter/panels/panel15.html.
} 
explore the Committee's wartime influence beyond 1941, asserting that World War II undermined Rapp-Coudert's findings by redirecting public attention to more pressing concerns of war and conflict. ${ }^{103}$

Commonly lost in the Committee's tale of repression and residual emergence is how the TU utilized its grassroots coalitions and patriotic vernacular to rebuff anticommunist attack. Thus, World War II did not solely dissolve anti-communist investigations, rather the TU diffused these investigations by galvanizing public support through grassroots strategies and popularized invocations of democratic education. In its initial campaigns, the union achieved a temporary stay against revealing membership lists by procuring the legal assistance of the American Civil Liberties Union, the Lawyers Guild, and the City Industrial Union Council. Additionally, the TU also constructed a broad-based labor alliance, as they sent members to lobby for assistance from municipal unions, meatpacking plants, hotels and restaurants workers, and the AFL and CIO. Enlisting creative talent, the TU won the support of 28 artists to illustrate "Winter Soldiers: A Conspiracy Against the Schools," a public pamphlet written in colloquial style designed to attract the public toward their cause. As the war progressed, the TU also depicted Coudert activity as an anti-democratic effort that threatened to undermine the nation's national unity. Reflecting the benefit of this community-minded and patriotic approach, Dr. Maxwell Ross, Democratic Representative of Brooklyn, announced his opposition to the Coudert Committee by asserting that "any investigation which may threaten the absolute unity of our people in the prosecution of the struggle we are now engaged should at this time be discouraged." Invoking Franklin Roosevelt's proclamation

\footnotetext{
103 "The Struggle for Free Speech at CCNY, 1931-1942," Iverson, The Communists in the Schools, 202; Hartmann, Education and the Cold War, 42; Murphy, Blackboard Unions, 185.
} 
that "the supreme achievement of enemy propaganda would be to create disunity," Ross asserted that the "controversy engendered by the Rapp-Coudert Committee ... will divide the enemies of Hitlerism and create an internal schism that will soften our nation in this tremendous struggle." 104

TU Legislative Representative Bella Dodd ultimately observed the tremendous success of these campaigns in attracting a broad-based constituency of support. In her memoir she noted that, "Little by little we won the campaign ... Support for the teachers, which at first had come only from the Communist Party, increased and included liberals, left trade unions, national group organizations, religious organizations then political parties of the left, then left-wing Democrats, then so-called Progressive Republicans." Ultimately, Dodd's brilliant legal counsel, the TU's grassroots strategies, and the union's popularized invocations of democratic education sustained the union. Compared to the Lusk Committee decades before, or the eventual McCarthy campaigns a decade later, the setbacks the TU endured were minor by comparison. Although still haunted by RappCoudert, teacher-citizens went into the war years with a renewed sense of purpose and academic freedom and championed one of the most radical approaches to civil rights and intercultural education. Thus, while anti-communists won the Coudert Commission of 1941, democratic progressives and the teacher-citizens secured victory during the war years. ${ }^{105}$

\footnotetext{
${ }^{104}$ Zitron, The New York City Teachers' Union, 1916-1964 (New York: Humanities Press, 1968), 32-38; Bella Dodd, School of Darkness (New York: The Devin-Adair Company, 1954), 121; "Dr. Ross Assails Coudert Probe as Peril to War Unity," Daily Worker, March, 19, 1942.

${ }^{105}$ Dodd, School of Darkness, 124.
} 
Throughout the war, democracy's semantic ubiquity and widespread expression led some reformers to argue that the term's overuse could mitigate its overriding power. Educational Professor George Hartmann warned that "the term 'democracy' is now in danger of being worked to death by its own friends. No one who utters it and few who hear it can fail to recognize that in current usage it means all things to all men." 106 Furthermore, after a Columbia-sponsored Congress designed to close the democratic rift between "educators and the lay public," one spectator observed "nothing is easier than to get people to express themselves publicly in favor of both democracy and education." 107 Indeed, whether tasked with arming for war, preparing for peace, fighting intolerance, or combating propaganda, democratic education found a broad and varied expression as a rhetorical ploy, a movement for educational reform, a cudgel in the game of oppositional politics, and a nationalistic call to arms. Wartime schools now functioned as the "first line of defense," endorsed programs of "eating democracy," "living democracy," and "cultural democracy," and assumed titles as the "citadels," "fortresses," and "arsenals of democracy." 108 Adding to this confusion, the Communist Party displayed an "unresolved tension" regarding "questions of democracy," as domestic communists espoused liberally democratic initiatives that stood in stark contrast to Soviet Russia's guiding ideals. Thus,

\footnotetext{
${ }^{106}$ George W. Hartmann, "Let's All Vote Before Going to War?," Frontiers of Democracy, 15 Nov. 1941, 41.

${ }^{107}$ Review of Education for Democracy: The Proceedings of the Congress of Education on Education for Democracy, by Harold Larrabbee, Ethics, April 1940, 351-52.

${ }^{108}$ Historian Robert Hampel characterized schools as "citadels" stemming from educator George Stoddard's 1944 image of high schools, President Franklin D. Roosevelt is largely attributed calling schools and colleges "fortresses," while historian Charles Dorn notes how Americans called for education to become "arsenals for democracy"; Carl Bankston and Caldas, Public Education: American's Civil Religion; Robert L. Hampel, The Last Little Citadel: American High Schools Since 1940 (Boston: Houghton Miffilin, 1986); "Education for Democracy, 1939: Annual Educational Conference sponsored by Teachers Union Local 5," Box 46, Folder 9, New York Teachers Union,; Dorn, American Education, Democracy, and the Second World War, 6.
} 
critics increasingly charged that democracy's permeation of educational and political discourse might lead to a confusion or even a diminution of democracy's centralized purpose both during and after the war.

Towards the end of the war, educators increasingly called for nations to become more democratically ordered and world-minded. Since the war accelerated trends towards "international perspectives," World History courses became a cornerstone of this approach. In addition, many educators asserted that previous World History courses pursued an egregiously flawed approach to world affairs and called for a curricular overhaul that encouraged students to become "citizens of the world." This approach moved away from the prior Committee of Reorganizing Secondary Education curriculum that stressed World History in the context of American ideals and called for demonstrating how America was "inextricably bound with the rest of the world." Thus, New York's World History curriculum urged teachers to avoid viewing global events through nationalistic lenses and stressed a global, interdependent framework that emphasized how "no person, no community, no nation is able to live adequately in isolation." Consequently, educators looked to build off a World History curriculum that confronted "dictator peril" by emphasizing the "quest for peace" and the increasing "interdependence of the nations of the world. ${ }^{109} \mathrm{~F}$ urthermore, educators pointed out that studies of World History and Geography textbooks documented the increasing need for “improving Asiatic studies," as textbooks commonly dedicated barely "more than a single sentence," to China, or "Japan "with which our country was at war." At the council on Wartime Policies of the National Council for Social Studies, Professor George Renner asserted that increased world knowledge should constitute a war measure, as Americans

109 “Schools Point to Dictator Peril," The New York Times, November 12, 1941. 
had erroneously been taught a "fairy-tale" curriculum in which "Holland was a cute little nation of windmills, tulips and cheese, whose spick and span democracy must always win because it is morally good; and in which Japan is a happy little place of cherry blossoms... whose leaders have been bad and must be punished." Therefore, as the war wound down, many educators asserted that the development of "world-minded citizens" should assume the foremost priority for all social studies teachers. ${ }^{10}$

Despite these advancements, many educators argued that a mere curricular reconfiguration was not enough and asserted that the outbreak of two World Wars demonstrated that a more dramatic reinterpretation of education's role in world affairs was needed. Indeed, numerous educators held teaching careers that spanned both world wars, and correspondingly lamented education's inability to prevent foreign conflict. As one Scottish schoolteacher regretted, "I am nothing — a school teacher who fought in the last war, and did nothing to prevent this one." Noting that "teachers have twice in a generation seen their most brilliant young people ... leave for the battlefield," one League of Nation's representative asserted that teachers should take a more active role in "this great movement for world security." In Education and the Cold War, historian Andrew Hartmann explained American's tendency to turn to education in crucial junctures observing, “Crises in education have arisen when a nation's future seemed uncertain, or worse, potentially bleak. Because nations are historically tenuous communities, national citizens must collectively imagine a national future." In this

\footnotetext{
${ }^{110}$ Andrew Spaull, "World War II and the Secondary School Curriculum: A Comparative Study of the USA and Australia," in Education and the Second World War: Studies in Schooling and Social Change, ed. Roy Lowe (London: Falmer Press, 1992), 161; "Education for World Citizenship," Folder 1, Series, 174, Records of the NYCBOE; Modern History: Course of Study and Syllabus, 13. Folder 1, Series 174 Records of NYCBOE; "U.S. is Seen Linked to World Destiny," The New York Times, December 9, 1944; "Neglected Millions," Progressive Education Association, October, 1945; "Training for Democratic Citizenship Is Stressed by Commission on Wartime Policy of National Council for Social Studies," The New York Times, November 28, 1942.
} 
scenario, teacher-citizens played a key role in imagining America's post-war future. Increasingly likened to as "planners," "architects," and "builders," teachers were called upon to construct "blueprints" for post-war affairs. Internationalist educators argued that the urgency of global conflict required the installation of a methodically crafted educational vision that would be implemented immediately after the war concluded. In doing so, this would mitigate the intellectual confusion that came from demobilization and defeat and would allow internationalist educators to seamlessly transition to their educational agenda. This curricular clarity was necessary, for "a third total war in the twentieth century-which must follow soon if we fail again — would mean the eclipse of democracy for untold generations." 111

The view of educators as post-war "architects" dedicated to ameliorating global tensions placed the wartime teacher in a unique and empowering situation. The wartime educator had to concurrently find ways to diffuse the ideologies that motivated Axis regimes, while installing new educational narratives that facilitated peace. This inevitably led educators to look toward the Third Reich as many contemporary analysts viewed the militarization of German youth as forming the ideological bedrock of German belligerence. Although recent studies have contested the idea of German youths marching in ideological lockstep, thinkers of the time increasingly believed global peace necessitated the expulsion of authoritarian doctrine. Reports of German curricula and teachings appeared to affirm these suspicions, as one German headmaster noted in his journal, "It goes without saying that we educators are using every opportunity both in the

\footnotetext{
111 "Education for World Citizenship," Folder 1, Series 174, Records of the NYCBOE; American Teachers Told They Must Prepare For Many Complex Post-War Problems," The New York Times, October 29, 1944; Hartmann, Education and the Cold War, 3; Marty Fisher, "If We Will-We Have the Future," Progressive Education Association, 98.
} 
classroom and in extracurricular activities and festivals to instill in the youth entrusted to us a clear understanding of the greatness of our Fuhrer and of this age shaped by him." Thus, Allied forces nearing the end of the war increasingly realized that liberation was not their only task. Rather a "re-education" aligned with the process of democratic education could purify German youth that had been subverted and ideologically corrupted. ${ }^{112}$

Educators warned, however, that a forced re-education of German citizens represented an act of compulsion that stood against democratic principles. Future United Nations, Educational, Scientific, and Cultural Organization (UNESCO) director Julian Huxley echoed these sentiments, noting that German "re-education" had to be constructed alongside a broader reimagination of "European re-education." This global foundation of intellectual collaboration and shared thought, Huxley claimed, would enable international bodies to replace the existing texts that fueled the Nazi regime, while constructing universalized narratives devoid of the nationalistic approaches that led to war. Furthermore, Huxley believed that a worldwide democratization of schooling, constructed upon an ideological blank slate, would avoid most countries' tendency to envision school as nationalistic vehicles. Reflecting Studebaker's philosophies, Huxley asserted that presenting educational ideas to an international forum of inquiry and critique would expose the distorted, militaristic, and nationalistic ideologies known to fuel impressionable youths and violent regimes. Consequently, in the dark month of November 1945, with the war barely over, representatives of over forty nations met in London and crafted the constitution of UNESCO. Believing that "wars begin in the minds

\footnotetext{
${ }^{112}$ Geoffrey Giles, "Schooling for Little Soldiers: German Education in the Second World War," in Education and the Second World War, 17-26.
} 
of men," UNESCO strove to create a globally collaborative foundation upon which nations could seek "peace through understanding." This moment ultimately marked the pinnacle of teacher's internationalist enthusiasm, as education assumed a new role in fostering global enlightenment and reason. ${ }^{113}$

While most of America's educators did not contribute directly to UNESCO's rise, the image of federated world-wide bodies aimed at cultivating peace and understanding contributed to a sizable peace movement spearheaded by educators. At a 1944 meeting of educators and peace groups sponsored by twelve international and domestic organizations, speakers urged teachers to become the "advance guard" in securing peace during post-war problems. Another speaker urged that teachers should become a "force" for peace, and suggested that teachers cultivate global understanding by acting as community leaders, staging talks at local meetings, addressing the press, and in "every feasible way" throw their professional energies behind the peace movement. Espousing a futuristic vision, college President William Mather warned that in the next war, American schools would not be immune to the threat of "robot bombs" and for that reason, educators had to do their "share" to create a permanent peace based on international understanding and cooperation. At the conclusion of the meeting, all speakers admitted that the most supreme question facing post-war schools was how to maintain peace through international and educational organizations. Consequently, those educators who witnessed students march off to one or two World Wars, increasingly dedicated their intellectual and creative energies to securing post-war peace. Translating their wartime strategies, teachers upheld the mantle of democratic education as they agitated within

\footnotetext{
113 Julian Huxley, "German Education and Re-Education," Frontiers of Democracy, May 15, 1943; Julian Huxley, UNESCO: Its Purpose and Its Philosophy (Washington D.C.: Public Affairs Press, 1947), 5.
} 
communities to solve global problems. Championing peace, these post-war teachers would ultimately conflict with educational pressures urging teachers to, once again, serve their schoolroom duty in yet another war. ${ }^{114}$

The aforementioned educational campaigns represented the culminating efforts of teacher-citizens and democratic progressives. As political scientist Robert Reich notes, "There may be greater dangers in failing to appreciate the power of public ideas and the importance of deliberation about them." Indeed, since war "magnifies the essential qualities of American institutions," it becomes especially important to dispel the notion that an American democracy at war consists of an educational system fashioned solely around military-industrial imperatives. And since World War II functions as a "usable past" in solving "today's problems," revealing the globally oriented, racially inclusive, and critically-centered philosophies behind educational mobilization helps disprove the very dangerous assertion that a wartime school's dominant purpose is to field capable workers and compliant soldiers. Rather it reveals that educational mobilization was not just militaristic, physical, and vocational but also intercultural, global, humanistic, and compassionate. ${ }^{115}$

One of the most significant educational transformation of World War II was the development of democratic education as an instrument of national purpose. Indeed, democratic education's fusion of governmental support and populist zeal led to an outpouring of educational philosophies from a broad segment of the American

\footnotetext{
114 “American Teachers Told They Must Prepare for Many Complex Post-War Problems.”

${ }^{115}$ Robert Reich, The Power of Public Ideas (London: Harvard University Press, 1988), 10; Andrew Spaull, "World War II and the Secondary School Curriculum: USA And Australia," 172; Michael C.C. Adams, The Best War Ever: America and World War II (Baltimore: The John Hopkins University Press, 1994), 3-4.
} 
population. As Americans increasingly came to view education as the way they could "remake themselves," democratic education came to embody both the nationalistic aims of the American government, and the democratic aspirations of its citizens. ${ }^{116}$ Old ideas of progressive education appeared staid, aged, and impractical, in the wake of a democratic education that looked modern and imbued with a sense of nationalistic urgency. While conservatives ushered in a wide range of reforms, the exigencies of World War II also forged a reconceptualization of democratic education that reshaped New York's schools' curriculum.

Framing their progressive initiatives in the context of democratic education and wartime need, democratic progressives forged educational coalitions with the community, while gaining valuable inroads into wartime schools. Unions such as the TU used their intellectual and neighborhood associations to champion civil rights, while creating curriculum that incorporated pioneering social science research into their schoolroom activities and intercultural programs. These grassroots campaigns helped give the union popular support that legitimized their educational agenda and repelled the anti-communist investigations of the union. On a broader level, the "teacher-citizen" restored teachers' sense of autonomy and academic freedom by encouraging educators to construct a curriculum that was adaptive, community-oriented, and critically founded. Thus, Dewey's ideals that schools should construct "democratic experiences" where students "lived democracy," suddenly emerged as popular tools to repel totalitarian behavior by immersing students in democratic practices. After these series of educational victories, there was growing interest in teachers as "architects" and "planners" in

\footnotetext{
${ }^{116}$ Carl Bankston and Stephen Caldas, Public Education-America's Civil Religion: A Social History (Columbia: Teachers College Press, 2009), 3.
} 
reconstructing American democracy after the war. Thus, democratic progressives came out of the war with an astounding sense of zeal and purpose and sought to translate their wartime victories into the post-war democratic order.

In the early postwar years democratic progressives would find these goals difficult to achieve. While the educational exigencies of World War II had legitimized these progressive initiatives, the Cold War's fear of educational subversion called these same initiatives into question. Exercises in critical thinking and controversial issues became increasingly derided as vehicles of schoolroom subversion. Organizations that published the collaborative findings of international groups of scholars threatened to contest America's educational programs that espoused Cold War master-narratives. More radical programs of intercultural education and civil rights, once endorsed as a tool for wartime unity, threatened to undermine democracy in a Cold War climate where Russia highlighted anti-democratic practices as a purported sign of America's democratic fraudulence. Correspondingly, teachers once valorized as teacher-citizens found themselves vilified as anti-American communists. Moreover, programs that once urged students to "live" their own democracy became supplanted by a Cold War curriculum that promoted its own normative ideals of democracy within American classrooms. Rather than yield to conservative advancement, democratic progressives sought to fight Cold War conflicts. In large part, this explains the contentiousness of New York's postwar educational battles. Indeed, the educational volatility of the Cold War did not just stem from anti-communist campaigns, as previously suggested, but rather originated over a clash of conservative and radical initiatives that both found widespread acceptance during World War II. This ultimately heightened the stakes of Cold War schools, as 
educational reformers of all stripes sought to be the dominant voice of educational change.

The rest of this study examines how these controversies manifested themselves in Cold Culture Wars that divided New York's schools and communities. The Cold War increasingly led the public to focus on schools as the primary agent to defeat Communism worldwide. Although most representatives acknowledged the schools needed to guard democracy and stem totalitarian aggression, few agreed on how education should accomplish such a feat. Tasked with rehabilitating American democracy at home and fighting totalitarianism abroad, American education became freighted with a host of newfound responsibilities and obligations, often outside the schools' reach. This development magnified the societal importance of the American school, as debates no longer hinged around purely education but rather over competing notions of American democracy. As educational policies took on new political dimensions, this simultaneously served to both cloud and enlarge the mission of American schools. Accordingly these expanded obligations opened education up to newfound educational constituencies rife with critiques, as they evaluated the ability of American schools to live up to their democratic promise. With this development, it is no surprise that New York's school board meetings became as pitched and politicized as the inner sanctum of its city councils. This ultimately caused one Cold War observer to remark that "our schools were not bombed as the European schools. But nearly two years after the war they are being wrecked just as surely they had been blasted by heavy bombers." ${ }^{117}$ Indeed, no longer were educational disputes the sole domain of rival educational camps. Rather educational

${ }^{117}$ Benjamin Fine, Our Children Are Cheated: The Crisis in American Education (New York: Henry Holt \& Company, 1947), 39. 
disputes once contained within schoolroom walls increasingly became hashed out in New York's schools, churches, labor unions, civic centers, and neighborhoods. These educational disputes, heightened in fury, and feverish in pitch, ushered in a new era of educational controversy that became part of America's Cold Culture Wars. 


\section{Chapter 4: Mutual Assured Instruction: "Playing it Safe" with Controversial Issues in the Cold War Classroom}

"We can't afford to teach them to be unbiased and let them make up their own minds." - Ellwood Turner, Secretary of Daughters of Colonial Wars

Commonly referred to as the "Great Condemnation," the "Great Meltdown," or the "Great Reappraisal," American public schools of the late 1940s and early 1950s faced a fever pitch of criticism. ${ }^{2}$ Throughout America, writers excoriating public education dominated national headlines, leading one observer to remark that "attacking the schools is assuming the proportion of cross-word puzzles, bridge, and golf as a popular pastime." Benjamin Fine, educational editor of the New York Times, reported in 1947 that "America's public school system is confronted with the most serious crisis in its history." Crafted in a ten-part series, Fine's writings often garnered front-page treatment with alarmist rhetoric observing that "the main bulkwork of the democratic way of life, the schools, have deteriorated to an alarming extent since Pearl Harbor." Indeed, Fine's wartime connection was rather apt. Only a few years before, World War schools had valiantly served as America's "first line of defense." Yet, now Cold War teachers appeared to occupy defensive postures, as pedagogical "warriors doing battle with an enemy storming the walls of public schools."

\footnotetext{
${ }^{1}$ Paul Blanshard, The Right to Read: The Battle Against Censorship (Boston: The Beacon Press, 1955), 96.

${ }^{2}$ In Dianne Ravitch, Left Back: A Century of Failed School Reforms (New York: Simon \& Schuster, 2000), Ravitch's chapter, "The Great Meltdown," explores the outpouring of criticism towards public schools during the 1950s. Andrew Hartmann, Education and the Cold War: The Battle for the American School (New York: Palgrave MacMillan, 2008), cites progressive educator Hollis Casswell's speech "The Great Reappraisal," while suggesting that "The Great Condemnation" be used as a more accurate label describing the abundance of post-war public criticism targeted at the schools.

${ }^{3}$ Benjamin Fine, Our Children Are Cheated: The Crisis in American Education (New York: Henry Holt and Company, 1947), 1; Dianne Ravitch, The Troubled Crusade: American Education, 1945-1980 (New York: Basic Books Inc., 1969), 6; William Reese, America's Public Schools: From the Common School to "No Child Left Behind" (Baltimore: John Hopkins University Press, 2005), 221; Joel Spring, The Sorting Machine: National Educational Policy Since 1945 (New York: Longman), 3-5.
} 
The educational lexicon of the Cold War assumed this "battle mentality," with words such as "attack," "siege," and "crisis" becoming synonymous with public education. According to a 1951 survey conducted by the National Commission for the Defense of Democracy through Education, attacks against public education notably increased in 1948 at an exponential rate surpassing any period before. Informing his fellow educators that "we need to be alarmed as were the Minute Men by Paul Revere in 1775 ," the executive secretary of the commission outlined teachers' need to aggressively organize on their own behalf. "If like the Minute Men, we are ready to carry out individual responsibilities of intelligent group planning, professional unity, organized action, and friendly contact with our allies," the secretary continued, "we will be as successful in defending our cause as were the gallant man at Concord." Years later, however, educators did not face an enemy visibly observed with the "whites of their eyes," but rather looming over their heads. Orbiting with a technological sophistication that seemingly invalidated the American mission of public education, Sputnik dramatized the fears of educational observers, and ushered in a fundamental transformation of American schools. The ensuing political paranoia and public frenzy led Hannah Arendt to remark, "Only in America could a crisis in education actually become a factor in politics."4

The roots of this decade long educational crisis has elicited tremendous debate within the history of education. Prevailing interpretations attribute these crises to the federal government's increasing involvement in schooling as a means of answering

\footnotetext{
${ }^{4}$ Hartmann, Education and the Cold War, 1; Spring, The Sorting Machine, 3-5; David Tyack, The One Best System: A History of American Urban Education (Cambridge: Harvard University Press, 1974), 270.
} 
unresolved questions of the post-war era. ${ }^{5}$ Altogether, these studies reveal how

Americans collectively entrusted their post-war schools with the formidable tasks of

promoting capitalism, confronting the Cold War, and resolving civil rights. In this regard, aspersions against public schools did not merely coincide with post-war tensions. Rather, Cold War schools served as a blank canvas upon which Americans projected the fears and anxieties germinated by the post-war era. Thus, the schools' democratic function as a beacon of social change and a magnet of public critique, ultimately led Americans to saddle the schools with solving everything, while criticizing them for resolving nothing. While historians have documented the overlapping concerns of civil rights, anticommunism, and academic rigor in fueling educational conflict, few have explored the tensions involved in the study of "controversial issues," such as the issues associated with intercultural education and world affairs. During World War II, New York's schools endorsed controversial issues as an inherently democratic process that stood in stark contrast to totalitarian modes of instruction. Indeed, many New Yorkers believed that the

${ }^{5}$ Lawrence Cremin, The Transformation of the School: Progressivism in American Education, 18761957 (New York: Vintage Books, 1961) attributes the educational crises to a confluence of variables, including teacher shortages, stalled school construction, and education's inability to supply the requisite manpower and highly skilled labor for America's burgeoning post-war economy. While later studies accepted the merit of this account, they also analyzed the piercingly shrill nature of these educational attacks. From these explorations, two dominant accounts focused on the unresolved questions of the post-war era. Joel Spring, in The Sorting Machine argues that the historic purpose of public education was to cultivate students' freedom of choice. This ultimately conflicted with the government's newfound desire to channel students into occupations deemed vital for Cold War national security. Consequently, conservatives asserted that the "soft" nature of post-war schooling emanated from the domineering and impractical influence of progressives, communists, and intellectuals, while academics condemned a curriculum sullied by "anti-intellectualism" and lobbied for a restoration of academic rigor and intellectual inquiry. Dianne Ravitch's The Troubled Crusade explores other causes for the educational crisis, illustrating how post-war education's commitment to providing an "equality of opportunity" for all led schools to become "magnets" for educational conflict and public dissension. Lastly, in David Tyack's and Larry Cuban's, Tinkering Toward Utopia: A Century of School Reform (Cambridge, Harvard University Press, 1995) both authors argued that that America has a historic legacy of approaching schooling as a "utopian" panacea in solving the nation's social, political, and economic ills. Thus, Americans increasingly look towards public education in times of crisis, which creates impossible and often heightened expectations that the school's are blamed for not resolving. 
war's spread of authoritarian regimes, propaganda, and racialized ideologies undermined America's unity and legacy of democratic achievement. Thus, intercultural education, independent thought, and the study of world affairs--often grouped under the umbrella of controversial issues--emerged as wartime measures of national security, as they were thought to foster racial unity, promote sobered assessments of world nations, and facilitate critical thinking crucial to diagnosing fascist strains of propaganda. This need for intercultural knowledge led schools to seek the counsel of pathbreaking scholars, while the drive for critical thinking led students to investigate the "excellent laboratory of social problems that New York City provides. ${ }^{96}$ Consequently, a New York school system previously derided for its isolation, now embraced the findings of external scholars who ushered in "one of the most audacious antiracist initiatives ever undertaken in American history." 7

By 1946, however, the intensely ideological nature of the Cold War forced a fundamental reevaluation of America's educational policies. Educational initiatives previously hailed as strengthening America's democratic resolve came under scrutiny for weakening America's democratic unity. This ideological shift entrenched Cold War schools in pitched educational battles, as democratic progressives sought to translate their radical initiatives into the post-war democratic order, while conservatives sought to stifle any program smacking of schoolroom subversion. These rival factions further clouded the issue by voicing divergent educational beliefs that were grounded within similar

\footnotetext{
${ }^{6}$ The Committee for the Study of Practical Democracy in Education, Report, 1943, 8, 23-29, Folder 1, Series 175, Records of the New York City Board of Education, Municipal Archives, New York, NY (hereafter cited as Records of NYCBOE).

${ }^{7}$ Zoe Burkholder, Color in the Classroom: How American Schools Taught Race: 1900-1954 (Oxford: Oxford University Press, 2011), 5; Lauri Johnson, “'Making Democracy Real': Teacher Unions and Community Activism To Promote Diversity in New York City Schools, 1935-1950,” Urban Education 37 (2002): 567.
} 
expressions of democracy. Thus, anticommunists branded the study of controversial issues as a vehicle for subversion, while democratic progressives promoted the process as a means of forging strong democratic minds. Proponents of intercultural education upheld their movement as a tool to perpetuate democratic progress and cultivate racial unity, while detractors blasted racialized curriculum as a means to sow societal discord and discredit America's world standing. Furthermore, the study of world affairs and especially cultural studies of Russia triggered perhaps the most intense and ferocious debates. Reactionaries asserted such instruction existed solely to tout the merits of Soviet Communism, while supporters argued Russian studies prevented the polarized misunderstandings that might precipitate future bloodshed. Consequently, Cold War schools straddled a contradictory position of promoting democratic expression while vigilantly guarding America's democratic ideals. Thus, the need to promote democratic expression lent credence to classroom deliberation and debate while guarding the nation's ideals meant enshrining a particular democratic narrative that those in power sought to project.

In this chapter, I aim to show how controversial issues animated and were influenced by larger post-war conversations of foreign affairs, race, and American democracy. In doing so, I aim to answer Thomas Sugrue's call to "bring the North back" into the broader civil rights struggle, while also establishing the struggle over the study of controversial issues as a significant touchstone of the post-war educational crises. ${ }^{8}$ Historians have extensively documented anti-communism's impact upon Cold War schools, exploring conflicts over academic freedom and the dismissal of educators for

\footnotetext{
${ }^{8}$ Thomas Sugrue, Sweet Land of Liberty: The Forgotten Struggle for Civil Rights in the North (New York: Random House, 2008), xiv.
} 
Communist suspicions. ${ }^{9}$ Yet, few studies have explored the dominant tensions around the study of controversial issues in the Cold War classroom. ${ }^{10}$ To compound the problem, these examinations largely adhere to conventional narratives that solely stress the controversial contributions of post-war educators and the dismantlement of their programs. ${ }^{11}$ Yet, exploring high-profile instances of repression and anti-communist showdowns renders an incomplete picture of Cold War educational conflict. Indeed, this narrowed focus conceals the array of equally pernicious administrative tools that schools used to silence progressive programs. Furthermore, the assumption that educators, teacher unionists, and civil rights activists passively complied with anticommunist repression obscures the overwhelming militancy and activism of democratic progressives. This focus on repression serves to perpetuate erroneous assertions that the Cold War instructional climate was mostly conservative, while obscuring the abundance of external authorities and forces that influenced educational thought.

\footnotetext{
${ }^{9}$ Ellen Schrecker, No Ivory Tower: McCarthyism \& The Universities (New York: Oxford University Press, 1986) analyzes anti-communism's influence on academic freedom, and explores academia's institutional response to political repression. Although predominantly a study of professionalism in the teaching profession Marjorie Murphy, Blackboard Unions: The AFT \& The NEA, 1900-1980 (Ithaca: Cornell University Press, 1990) addresses how the ideology of professionalism ultimately reinforced the anticommunist attacks upon the New York City Teachers Union (TU), while hampering the union's organizational growth. Robert Iverson's investigation of Communists and the Schools (New York: Harcourt Brace and Company, 1959) provides insight into the anxieties and political tensions driving anti-communist investigation into the schools, while largely avoiding the responses of those affected. Clarence Taylor, Reds at the Blackboard: Communism, Civil Rights, and the New York City Teachers Union (New York: Columbia University Press, 2011) mounts one of the most comprehensive accounts of anti-communism's impact in New York schools, addressing the social, cultural, and political factors that shaped anticommunist investigations, and the subsequent counteroffensives waged by the TU.

${ }^{10}$ Although Andrew Hartmann's, Education and the Cold War does not directly explore controversial issues, the work's fine examination of progressive education, UNESCO and "world-mindedness," and occasional conflicts over intercultural education and black history provides a superb analysis of the issues driving the debates over controversial instruction.

${ }^{11}$ Celia Zitron's institutional history of the TU and Ruth Markowitz's examination of Jewish TU teachers offer insightful studies into TU teachers and their fervent commitment to intercultural education, labor activism, and grassroots politics. Although their stories of anti-communist repression are equally as compelling, the victim-centric nature of these studies renders a more one-dimensional account of the anticommunist forces entering into New York's schools. Celia Zitron, The New York City Teachers' Union, 1916-1964 (New York: Humanities Press, 1964); Ruth Markowitz, My Daughter the Teacher: Jewish Teachers in the New York City Schools (New Brunswick: Rutgers University Press, 1993).
} 
Lost in the story of contribution and repression of the left is how Cold War schools attempted to circumscribe the discussion of controversial issues, and the campaign of progressive educators, liberals and leftist unionists to save these initiatives. In Cold War Civil Rights, historian Mary Dudziak argues that the Cold War's international focus on U.S. racial problems forced the federal government into a contradictory position of promoting racial change at home, while also seeking to narrow and define more acceptable civil rights discourse. ${ }^{12}$ Building upon Dudziak's model, I argue that democratic education's popularized emergence as a tool of national purpose served to legitimize the democratic discussion of controversial issues while also narrowing the process of controversial instruction. Indeed, Cold War educational policy was borne out of a complicated and often contentious political milieu that embodied nationalistic designs while also being accountable to the democratic educational demands of an ever-involved public. Examining the struggle over controversial issues reveals how Cold War schools had to balance both under-represented groups speaking in democratic terms and anticommunists grounding their concerns in democratic mandates of patriotic accountability.

Intercultural education's increased public exposure also meant that the movement came to be defined as much by its critics as it was by its practitioners. While New York's schools often conceded to public pressure and adopted more progressive programs, they also employed administrative mechanisms to create more acceptable modes of controversial and intercultural instruction. Indeed, the more radical programs that had won widespread support during World War II were often dismantled by administrative

\footnotetext{
${ }^{12}$ Mary Dudziak, Cold War, Civil Rights: Race and the Image of American Democracy (Princeton: Princeton University Press, 2000).
} 
maneuvers outside the purview of anticommunist investigation. Replacing these activities were lessons informed by a directed democracy approach, a term which I am using to mean instruction that guided students towards select democratic narratives that promoted the U.S. government's Cold War policy while veering students away from conversations which explored America's anti-democratic tendencies.. This more subtle practice of directed democracy enabled the schools to market their theoretical embrace of intercultural diversity and open discussion of world affairs, while they crafted a homogeneity of curricular narratives. In doing so, New York's Board of Education (BOE) hoped to deflect and minimize the public pressure that may come from dismantling the school's popular programs. Furthermore, the Board also aimed to mitigate the influence of external actors who shaped curriculum in order to craft instruction more suited to a Cold War environment that desired safe and predictable democratic narratives. While this chapter examines efforts to repress intercultural education and the study of the Soviet Union, chapter four focuses on the continuing struggle of democratic progressives and their allies to promote democratic education in postwar New York schools.

The fate of Cold War intercultural programs was ultimately shaped by an uncertain America wavering in its "racial and civic conceptions of nationhood." In American Crucible, historian Gary Gerstle illustrated how Cold War Americans deviated from a "racial nationalism" that emphasized citizenship in ethnic and racial terms to a "civic nationalism" that viewed citizenship through American commonalities of belief and purpose. Gerstle asserted this transition stemmed from the "mounting hysteria" of 
Communism that often overshadowed racial and ethnic considerations. Thus, Americans of varying cultural, racial, and religious backgrounds often prioritized the fight against Communism over other domestic campaigns that called America's democratic practices into question. Historian Barbara Ransby believes this civic shift fundamentally altered "liberal-left coalition work" as anticommunism coursed throughout movements in labor, politics, and civil rights. Subsequently, civic discourse narrowed, as leftist coalitions discarded their more structural critiques of race and American democracy in favor of more acceptable dialogue that advanced liberal interests while avoiding anti-communist reprisal. ${ }^{13}$

Contests over anticommunism and civil rights took on profoundly heated dimensions in post-war New York. Numerous scholars have responded to Jacquelyn Hall's call for a "long civil rights movement" by illustrating how post-war New York became embroiled in expansive civil rights showdowns that helped support AfricanAmericans who had "few allies" in their quest for racial equality. ${ }^{14}$ Occurring a decade before the iconic civil rights clashes of the South, these grassroots campaigns spurred New York's labor unions and communist left to pursue issues of racial discrimination in avenues of politics, housing, education, and employment. The power and scope of these campaigns ultimately drummed up so much widespread public support that a New York

\footnotetext{
${ }^{13}$ Gary Gerstle, American Crucible: Race and Nation in the Twentieth Century (Oxford: Princeton University Press, 2001), 237-241; Barbara Ransby, Ella Baker and the Black Freedom Movement: A Radical Democratic Vision (Chapel Hill: University of North Carolina Press, 2003), 159.

${ }^{14}$ For the original call for the "long civil rights movement," see Jacquelyn Hall, "The Long Civil Rights Movement and the Political Uses of the Past," Journal of American History 91 (March 2005). For a superb analysis of post-war New York's earlier civil rights battles see Martha Biondi, To Stand and Fight: The Struggle for Civil Rights in Post War New York (Cambridge: Harvard University Press, 2003), while Clarence Taylor, Reds at the Blackboard: Communism, Civil Rights, and the New York City Teachers Union (New York: Columbia University Press, 2011) offers great analyses of the New York City Teachers Union and their efforts to wage educational campaigns for civil rights. Lastly, Thomas Sugrue, Sweet Land of Liberty: The Forgotten Struggle for Civil Rights in the North (Random House, New York, 2008) serves as a great historical compendium in learning about civil rights battles throughout the North.
} 
Age editorial indicated, "1946 can be the most epoch making year in the history of our race. It can be the year when the Negro reaches first class citizenship in this country." 15 Yet, these progressive operations were ultimately contested by the intense ferocity of New York's conservative right who found their efforts legitimized by the nation's broader anticommunist crusade. While New York's activist left organized in labor unions, picketed discriminatory employers, and fought for improved public services, the city's conservative right worked to defang the power of organized labor, silence political dissent, and shatter civil rights coalitions. Consequently, post-war New York became America's litmus test for the nation's larger anticommunist and civil rights battles, which engaged in a "frequent difference of opinion in how black and white liberals conceptualized the pathway to race reform." With conceptions of civil rights "conceptually, doctrinally, and constitutionally up for grabs," and with "the boundaries of the bureaucratic state, the form of individual rights, and the relationship between them still unclear," Americans of all political stripes enlisted the schools in these broader civil rights struggles. ${ }^{16}$

As a result, America's rising belief in civic nationalism and anticommunist thought came to contest intercultural education's more radical critiques of racial discrimination. Previously, wartime intercultural programs sought to reduce racial tensions by combating the biological fallacies and discriminatory institutions impeding black advancement. Merging with the social sciences enabled interculturalists to justify their more systemic political attacks by employing scientific data grounded in apolitical insights and rooted in empirical objectivity. The nationally popular "Springfield Plan"

\footnotetext{
${ }^{15}$ Biondi, To Stand and Fight, 1.

${ }^{16}$ Jonna Perrillo, Uncivil Rights: Teachers, Unions, and Race in the Battle for School Equity (Chicago: The University of Chicago Press, 2012), 49.
} 
used intercultural insights to revamp school curriculum, while also teaching "tolerance and respect" by explicitly hiring black teachers and confronting discriminatory hiring practices. ${ }^{17}$ These curricular practices spread to over twenty-two states, while New York City's Public Schools created similar intercultural in-service courses that reached the city's 10,000 teachers and millions of students. The onset of the Cold War, however, sparked a directed democracy approach that sidestepped assessments of American domestic policy by fixating on the presence of prejudice within the individual. Thus, the social sciences were employed not to survey the impact of institutions upon minorities, but rather to ameliorate the "human relations" between varying racial, ethnic, and religious groups. Ostensibly an organic evolution in intercultural thought, the fusion of directed democracy with human relations actually served to reinforce Cold War imperatives. Indeed, at a time when U.S. racial problems tainted the international image of American democracy, focusing on the "individual" shifted the conversation away from American complicity in racial inequality while charting entirely new dialogues about the country's role in facilitating racial progress.

In this way, the tandem of directed democracy and Human Relations helped function as a public relations vehicle for a Cold War America embattled with racial division. For example, in 1947 the Institute for Democratic Education sponsored the radio series, Lest We Forget— the American Dream, which dramatized individuals fight against prejudice through the use of carefully crafted vignettes. Featuring acclaimed and Oscarnominated stars, and airing for free in radio stations across the country, Lest We Forget portrayed Helen Hayes as a schoolteacher discussing the harm of racial epithets, Ralph

\footnotetext{
${ }^{17}$ Robert Shaffer, "Multicultural Education in New York City During World War II," New York History, July 1996, 325.
} 
Bellamy as a "courageous" sheriff protecting a Mexican youth from a lynch mob, and Sam Levine as a Jewish cab driver who faces anti-Semitism and "becomes a hero." Indeed, listeners may have been shocked that such prejudice existed in a country that consistently extolled its morally pure democratic character. Yet, by wedding Hollywood production values to psychological insights, Lest We Forget sought to convince listeners that Americans were committed to improving human relations through the use of the nation's supreme cultural and intellectual capital. ${ }^{18}$

San Diego's post-war schools also adopted Human Relations programs that avoided the American West's Jim Crow realities. During World War II, AfricanAmericans migrating to the West encountered a scarcity of housing, occupational discrimination, and restrictive racial covenants barring blacks entrance into white neighborhoods. Historian Mark Brilliant argued that blacks post-war campaigns to confront Western Jim Crow ultimately made California a "national bellwether for civil rights action" as well a "harbinger of national civil rights reaction." ${ }^{19}$ Consequently, San Diego's schools responded to the city's increasing racial tension by creating Human Relations programs that fostered a "due respect for the members of other cultural groups" and instructed about "cultural backgrounds" in order to cultivate students sense of "common loyalty and purpose in making American democracy work effectively." This more "generic study of cultures" ultimately overshadowed prior examinations of "race relations in the schools and local communities." One official report listed how "the Oklahoma boy was invited to share his knowledge of farming ... and the southern Negro

18 "Drama Series to Fight Prejudice Will Bow on WNEW Tuesday," The New York Times, 27 Jun 1947; Lawrence Samuel, The American Dream: A Cultural History (Syracuse: Syracuse University Press, 2012), 46.

${ }^{19}$ Mark Brilliant, The Color of America Has Changed: How Racial Diversity Shaped Civil Rights Reform in California, 1941-1978 (Oxford: Oxford University Press, 2010), 6. 
lad was invited to tell the story of the production of sugar." ${ }^{20}$ Thus, San Diego's schools refused to address racial issues that tarnished America's Cold War standing and rather resorted to cultural lessons that emphasized individual relations and minority achievement. Looking at these lessons, few observers would know that the state of California "was at the forefront" of civil rights battles waged over fair housing and fair employment. $^{21}$

Other mediums similarly marketed America's post-war efforts in improving human relations. Magazines nationwide touted the psychological advancements shaping intercultural thought, while capturing the efforts of political and educational figures in unveiling Human Relations workshops and "brotherhood" programs. Other newspapers that had previously depicted playgrounds entrenched in intergroup conflict now highlighted students' racial cooperation in solving problems and confronting schoolroom projects. ${ }^{22}$ In one article entitled "Melting Pot Boils In This High School," the New York Times ran a photo that depicted a "symphony of cultures" as students of varying ethnicities marveled at their peer's artistic creations. ${ }^{23}$ As Zoe Burkholder asserted in Color in the Classroom, these articles were representative of many newspapers that often circumvented discussions of racial inequality by redirecting their stories to tout narratives

\footnotetext{
${ }^{20}$ Yoon Pak, "If there is a Better Intercultural Plan in any School System in America, I Do Not Know where it is": The San Diego City Schools' Intercultural Education Program, 1946-1949," Urban Education 37 (November 2002): 589-598.

${ }^{21}$ Brilliant, The Color of America Has Changed, 5.

${ }^{22}$ Although newspaper accounts documenting racial strife on playgrounds were abundant in the early 1940s, the most qualitatively and analytically scathing newspaper account of racial conflict can be found in "Steps Urged to Cut Racial Conflicts in upper West Side," The New York Times, 23 Dec 1946. According to reports released by the Mayor's Committee on Unity, 31,000 students in Manhattan were found to be involved in playground clashes. Furthermore, 30 percent of parents who were interviewed indicated that their children had been involved in racial classes, with nearly $25 \%$ indicating that the conflicts "had been serious."

23 "Melting Pot Boils In This Classroom," The New York Times, December 14, 1952.
} 
of interracial cooperation and racial progress. ${ }^{24}$ While youths of the 1940s would fight for political and economic rights in subsequent decades, these newspaper accounts made it seem as though racial equality had already been secured in the "meeting grounds" of the Cold War classroom. In newspapers, television shows, and articles throughout America, directed democracy helped portray a Cold War nation that consistently appeared on the verge of racial progress.

The political and educational tensions surrounding the study of "controversial issues" ultimately meant that intercultural education entered the post-war years in the midst of a pronounced ideological flux. In her post-war study of McCarthyism, Ellen Schrecker asserted that conservatives increasingly connected agitation for "racial equality" to a Communist Party technique that concurrently appealed to AfricanAmericans while fomenting political discord. ${ }^{25}$ As more moderate interculturalists increasingly emphasized individual prejudice, activities looking to redress America's legacy of racial inequality assumed subversive connotations. Consequently, the divergence between the scientific and psychological philosophies informing intercultural activity became perceptible in student activities and in the ruminations of fellow teachers. Indeed, New York's Cold War pupils rarely investigated racial discrimination in their communities, rather they visited the city's "anti-bias centers" to ease "racial strains" with their individual classmates. Teachers advocating critical lessons on "American practices in housing, in education, in employment, [and] in political rights," gradually disappeared from the intercultural landscape. Instead, some New York's schools favored a "Human

\footnotetext{
${ }^{24}$ Burkholder, Color in the Classroom: How American Schools Taught Race, 1900-1954, 168.

${ }^{25}$ Ellen Schrecker, Many Are the Crimes: McCarthyism in America (Boston: Little, Brown and Company, 1998), 151.
} 
Relations Workshop" that trained teachers in modern techniques of "sociometric testing" that mapped evidence of racial "cleavage or exclusion in the classroom." In other schools, many teachers avoided discussions of civil rights and racial inequality, opting to direct students towards positive and less contentious lessons on "cultural democracy" and minority group achievement. Consequently, intercultural education straddled a precarious instructional balance that addressed the intolerance of the individual while skirting the ideals underpinning racial discrimination. Caught in-between these opposing approaches, both of which had won widespread support in separate ideological conflicts, intercultural education evolved into a bifurcated field that elicited both liberal praise and conservative panic. $^{26}$

Public conflicts over these differentiated intercultural approaches ultimately clashed in a highly publicized controversy that sparked the dissolution of New York's intercultural and world affairs in-service programs. Starting in late 1947, the WorldTelegram and The Tablet published numerous articles designed to expose the purportedly subversive figures delivering intercultural instruction. Journalistic attention largely centered on Columbia Sociologist Bernhard Stern, an ARI representative and lecturer slated to help instruct the course, "The Soviet Union Today." In his account, WorldTelegram columnist Frederick Woltman revealed that Stern previously wrote a 1930 pamphlet, "The Church and the Worker," that criticized organized religion under the pseudonym "Bennett Stevens." The next day, The Tablet used Woltman's expose to launch a more systematic broadside against intercultural education, noting, "there are

\footnotetext{
${ }^{26}$ Anti-Bias Centers Slated in Schools," The New York Times, April 21, 1949; Burkholder, Color in the Classroom, 142; "Human Relations Workshops Devote Another Summer Session to Community Problem," The New York Times, August 3, 1952; "Bureau Attempts to Allay Tensions," The New York Times, March 4, 1950; Burkholder, Color in the Classroom, 141, 152-156.
} 
certain words which, after years of respectability, suddenly fall into disrepute because of questionable associations. The world intercultural ... has now generally come to be associated with propaganda of the Community Party line." These critiques raised special concerns during the Cold War, as New York's schools required educators to attend such instruction for "alertness credits," which were linked to teachers' increased salary and professional status. While a majority of wartime educators attended such instruction on their own volition, Cold War critics now questioned why teachers' economic and professional standing was linked to mandated courses that were viewed as a source of subversion and philosophical contention. Consequently, New York's Board of Superintendents bowed to public pressure and initiated an investigation into the background of the Stern and his in-service courses. ${ }^{27}$

Obscured in intercultural histories, Stern's investigation signified the widening gap between Human Relations and the more scientific approaches to intercultural instruction. At his investigation, Stern defended his purportedly divisive statements by couching them within a distinct academic tradition of critical inquiry and investigation. For example, when asked to clarify his Depression-era assertion that "religion obscures a worker's understanding of his place in society," Stern responded to the Board that the "study and critique" of human institutions was necessary to prevent a descent into moral and ethical stagnation. Stern further added that frequent criticism helped demystify the “obscurantist" policies of institutions working against the public interest. Thus, Stern's defense echoed the tradition of earlier interculturalists by asserting that intense moral and

\footnotetext{
${ }^{27}$ Frederick Woltman, "3 Commie Course Instructors Hold City Lecture Jobs," World Telegram, October 10, 1947; "Another School Course Conducted by Leftists," The Tablet, October 18, 1947; "City Sponsors Course by Reds for Teachers," The Tablet, October 1947; "In-Service Courses for City Teachers," New York Times, January 23, 1944; found in Folder 11, Series 634, Records of NYCBOE.
} 
public appeals, fashioned around research and critical analysis, were integral to improving the human condition. Reflecting this scholarly objectivity, the embattled sociologist conceded that the passage of time and availability of new evidence would force him to revise his earlier views, as he had already done with "several of his scientific books." Thus, Stern deflected Board accusations of his promoting "disunity" by firmly rooting his pedagogical rationale within a framework of scholarly objectivity and inductive reasoning. In doing so, Stern maintained he was merely defending the "sociological" approach that caused led him to chosen for his in-service lectures, which had been staged repeatedly "during the last few years without criticism from any source. ${ }^{28}$

In their findings, however, the Board found that Stern's comments violated the central precepts governing proper Human Relations. The Board charged that Stern's statements against "Protestants, Jews, and Catholics" constituted an egregious "attack on all religious faiths." Thus, the Board refused to view Stern's assertions as a categorical analysis of organized religion and rather characterized his statements as broadly "antireligious" in character. Noting that intercultural courses facilitated "disunity," Associate Superintendent Jacob Greenberg added that Stern was "supposed to lecture on unity, and in the opinion of the board, his appearance will not serve that cause." Subsequently, the Board declared Stern "unfit" to instruct future programs of intercultural understanding, as his statements stood antithetical to the harmonious atmosphere that New York's schools were striving to create. ${ }^{29}$

\footnotetext{
${ }^{28}$ Record of Conference with Mr. Jacob Greenberg and George Pigott, n.d., Folder 5, Series 634, Records of NYCBOE; "Dr. Stern Protests Canceling of Course," The New York Times, December 18, 1947.

${ }^{29}$ American Russian Institute: Extracts from Minutes of Board of Superintendents, Folder 5, Series 634, Records of NYCBOE; Burkholder, Color in the Classroom, 153; Herbert Donovan to Jacob Greenberg,
} 
Religious groups had expressed concerns over intercultural courses before. Some of New York's Catholics, who comprised the city's most vocal anticommunists and intercultural critics, took umbrage at their intercultural classification as an "ethnic group," which suggested a deliberate religious downgrade to those who saw themselves as locked in a mission to defend the "Catholic faith in a secular world. Rebuking an inservice lecture scheduled to be delivered by Races of Mankind co-author Gene Weltfish, the predominantly Catholic Teachers Alliance of New York City observed that, "This course, if sponsored would probably be the cause of more inter-racial friction than it could possibly accomplish good.” The Managing Editor of Brooklyn's Catholic organ, The Tablet, also sent a letter to the Board of Education after he received an intercultural bulletin from an anonymous "school man" who protested that the roster of courses slated "for all teachers" was likely to "allay intercultural cooperation." Thus, the Board's ruling of Stern's intercultural disunity emanated from a tradition of intercultural critique that branded the curriculum as inherently divisive in character.

What distinguished these intercultural disputes from earlier eras was that they now played out in a thoroughly involved and participatory public arena. Previously relegated to plays, presentations, and speeches, intercultural education expanded into mainstream venues of motion pictures, magazines, and radio shows. These more modern "audio-visual educational techniques" injected the field into newfound mass mediums that enabled the field to mount emotionally resonant intergroup appeals while exposing the discipline to a broader American audience. Although these advances popularized intercultural activity, the field's more simplistic interpretations of race also exposed the October 29, 1945, Folder 1b, Series 634, Records of NYCBOE; "Criticized Courses for Teachers Halted," The New York Times, December 13, 1947. 
discipline to a louder chorus of education critics. Indeed, intercultural education's previously scientific nature bestowed a certain scientific authority and esotericism that effectively walled off the field from public critique. Yet, the Cold War's prioritization of national unity over racial progress provided an opening for the public to attack the critical and often arcane scientific material informing intercultural activity. Throughout post-war America, intercultural education was supposed to function as a supremely force that sought to preserve civic peace through positive expressions of racial understanding. As the New York Times touted, "We know that the struggle for democracy cannot be waged with bullets, shells, and atomic bombs ... In this crisis, friendship and teamwork among Christians and Jews, among all the groups that make up America, is mandatory."${ }^{\prime 30}$ Subsequently, the desire for national unity ultimately led critics to conflate interculturalists' more structural critiques as deliberately negative assessments of America's racial character. ${ }^{31}$

In stark contrast to World War II, Cold War intercultural critics now dismissed the scientific content of interculturalists by subjecting the curriculum to newfound mandates of patriotic accountability. Branding intercultural activity as "anti-democratic," "divisive," or "Communist" in character, enabled the American public to reduce the scientific findings of interculturalists without engaging in direct discussions of scientific knowledge. By couching their rhetoric within the Cold War political vocabulary, only rarely did intercultural critics have to directly refute the intercultural material they so stridently deplored. Rather, the isolated quotes and political associations of intercultural

\footnotetext{
30 "Brotherhood Seen as U.S. Strength," The New York Times, February 21, 1949.

31 "Bureau Attempts to Allay Tensions," The New York Times, March 4, 1950; "Brotherhood Seen as U.S. Strength," The New York Times, February 21, 1949.
} 
practitioners became focal points in investigations that sought to derail intercultural programs. ${ }^{32}$

By far, the most organized and active critics of intercultural education, whether moderate or radical, were New York's anticommunists, who tended to view intercultural instruction as a conspiratorial movement headed by a cabal of liberal dupes and Communist infiltrators. ${ }^{33}$ Stern seemingly fit this mold as his utilization of a pseudonym to engage in more transparent commentary of controversial issues meshed with anticommunists' portrait of interculturalists as dabbling in pedagogical subterfuge and employing "backdoor approaches." Furthermore, Stern's critical views of organized religion aligned with broader suspicions that interculturalists sought to engage in a process of "reorientation" in order to "break down" American tradition. Increasingly, this led intercultural critics to draw a pronounced linkage between critical views of American institutions and Communist subversion. As The Tablet observed of intercultural inservice courses during the controversy, "One lecture on the means of combatting prejudice might be expected in such a course — but six? This over-emphasis on prejudice is part of the party-line technique which seeks to divide and conquer by stirring up hate among minority groups by making them feel more discriminated against than they actually are." In this light, Stern was not just a Communist, but also a radical seeking to aggravate racial tensions in a city fraught with intergroup conflict. By extension, New York's schools appeared to be sanctioning courses that sowed division and discord in a Cold War climate that necessitated harmony and democratic brotherhood. Consequently,

32 “Teachers' Course Called Red-Tinted," New York Times, April 25, 1953.

33 "Teachers' Course Called Red-Tinted"; Burkholder, Color in the Classroom, 153. 
detractors came to brand in-service instruction with the rhetoric and motivations that they commonly attributed to the Communist Party. ${ }^{34}$

These growing anticommunist suspicions were evident in the Board's continued handling of ARI in-service courses. Highlighting the tenuousness of Russian studies, even the ARI's characteristically neutral evaluations of Soviet Russia were now suspected to contain elements of subversion. In 1947, "Miss Riley" observed that the institute's in-service course contained "nothing" resembling Soviet propaganda and that a teacher aspiring to juxtapose American and Soviet forms of government could utilize the information presented to craft a sufficiently insightful lesson. Despite this endorsement, Riley also critiqued the course's impartiality, noting that potentially subversive teachers could use the "same information . . . to depreciate the American way." Indeed, Riley's observations aligned with school administrators' recent comments that some ARI courses had "tried to remain factual" in what appeared to be a "superficial and misleading way." 35 Whereas the ARI's adherence to scholarly objectivity had won Board approval during World War II, the institute now faced a Cold War environment where even factuality was now deemed suspect. Consequently, the ARI bore the brunt of conservative critique as the World Telegram, Plain Talk, and American Mercury consistently leveled charges against the "un-American" and excessively "communistic" nature of the institute's Russian courses. ${ }^{36}$

\footnotetext{
34 "Teachers' Course Called Red-Tinted"; Woltman, "City Sponsors Course by Reds for Teachers." ${ }^{35}$ Suspicions of curricular neutrality were further evidenced in question and answer sessions, where observers noted that the "left-wing" audience members asked questions "not because they wanted information," but rather to bolster their own views and background while cementing "certain points."

${ }^{36}$ Report on the Fifth Lecture of the American Russian Institute, Folder 9, Series 634, Records of the NYCBOE Stern, Bernhard Stern to Rose Rubin, October 22, 1947, Folder 9, Series 634, Records of the NYCBOE.
} 
Anticommunists, the press, religious groups, and school officials all extracted meanings from intercultural material that often aligned with their anxieties regarding the post-war world. While civil rights contested post-war Americans' understandings of race, intercultural education provided a more static arena for Americans to argue how ideas of race should be presented. Therefore, critiquing intercultural education enabled Americans to address their own societal grievances in rapidly evolving confines of post-war New York. This ultimately politicized intercultural materials to the extent where any slight, omission, excess of attention, or dearth of attention granted to New York's tapestry of religious, ethnic, and racial communities could invite a pronounced public backlash. Occurring against the backdrop of the "most serious" educational crisis in history, these critics were able to shape intercultural material by pressuring a politically cowed Board to place curricular restrictions on intercultural activity. ${ }^{37}$ Consequently, intercultural alarmists expressed their fears throughout the city, publishing their concerns in the city press, organizing letter writing campaigns to school officials, and airing their grievances in the contentious and highly publicized arena of New York's Board meetings. Thus, intercultural education became immersed in an overlapping and complicated political milieu where one solitary lecture could elicit a swath of criticism from a diversity of public voices. In this way, Stern's controversy not only provided a test case for anticommunists in confronting subversive content, but also portended the highly contested ideological battles gripping post-war intercultural instruction.

The fact that the Stern case evolved from an obscure schoolroom conflict into a public controversy necessitated that the Board adopt more aggressive measures towards intercultural activity. In his study of New York's schools in 110 Livingston Street,

\footnotetext{
${ }^{37}$ Benjamin Fine, Our Children Are Cheated, 1
} 
sociologist David Rogers asserted that New York's schools did not "passively reflect public opinion," but rather developed a comprehensive set of "strategies" to balance the "pressures and counterpressures" emanating from New York's pressure groups and coalitions. In particular, Rogers noted how New York's schools managed discussion of "controversial issues" by engaging in stall tactics of "dialogues" and "studies," while clouding their subsequent rulings in the bureaucratic legalese of advanced policy statements. These actions, embodying what New York Times educational writer referred to as "New York City Syndrome," were typically used to stall "genuine innovation" and were evident in the Board's handling of in-service instruction. Indeed, after dropping Stern and the ARI from their list of approved courses the Board ordered a temporary postponement of all intercultural in-service courses in order to study the field and "come to an understanding about [its] underlying aims and philosophies." Despite the Board's concession that its findings were "practically completed" on February 11, 1948, administrators did not release their findings until the summer months of vacated schools and dispersed teachers. ${ }^{38}$

The "Plan for Workshops in Intercultural Education" ultimately contained a series of "recommendations" that ushered in the demise of the city's grand intercultural experiment. In an attempt to pacify intercultural critics, the Board installed curricular safeguards that sealed off the schools from external authorities on race and foreign policy. Altogether, the Board's recommendations regulated the entirety of intercultural in-service instruction, including the selection of lecturers, approval of universities and organizations, and even lecturers' topics. For example, the Board sought to shape the

\footnotetext{
${ }^{38}$ David Rogers, 110 Livingston Street: Politics and Bureaucracy in the New York City Schools, (New York: Random House, 1968), 3-14; David Alison, Searchlight: An Expose of New York City Schools (New York City: Teachers Center Press, 1951), 123.
} 
instructional body of their guest lecturers by creating a screening process that prioritized a lecturer's ideological conformity over quality of instruction. With conventional inservice courses, the Board merely required "that the instructors be qualified by training and experience to give the course." Yet, administrator's "screening process" for intercultural lecturers was subject to a more intrusive set of evaluative criteria. Indeed, the Board's newfound emphasis on ambiguous metrics such as "personality" and "background" enabled the Board to reject lecturers who failed to abide by the standards New York's administrators were trying to implement. The issues associated with this rather nebulous screening process were further evidenced when the Board of Superintendents neglected to sponsor a Human Relations course organized by the National Conference of Christian and Jews due to the purported difficulty of "securing information about speakers ... who in some cases took an undesirable line." ${ }^{\prime 39}$ In another instance, the chief evaluator of in-service courses, Principal Mary Meade, conceded she could not impartially evaluate a prospective course because of the distaste she held toward a particular lecturer. ${ }^{40}$

The Board also responded to "pressures from various opposition groups" by appointing a "committee to investigate all [intercultural] courses " and to ensure an instructional adherence to their curricular changes. ${ }^{41}$ With civil rights conflicts raging in the "largest racial and religious ghetto of any city in the world," the public blowback surrounding intercultural education often proved more polarizing than the curriculum

\footnotetext{
${ }^{39}$ Lauri Johnson, 582.

${ }^{40}$ Plan for Workshops In Intercultural Education, Folder 9, Series 634, Records of the NYCBOE; Mary Meade to William Jansen, September 22, 1948, Folder 9, Series 634, Records of the NYCBOE.

${ }^{41}$ Layle Lane lamented these "pressures" in Layle Lane to Carol Zillman, March 1, 1949, Box 11, Folder 9, New York Teachers Guild Records, 1923-1957. 5279. Kheel Center for Labor-Management Documentation and Archives, Cornell University Library (hereafter cited as Records of New York Teachers Guild);
} 
itself. $^{42}$ Thus, the Board restricted the latitude of topics instructors could explore by urging that all in-service courses focus on the "practical every-day problems" that related, "in whole or in part to the work the teacher is doing in the public school." Also, the school's guidelines for teaching "Human Relations" shifted focus from contesting the discriminatory acts of institutions and toward improving the racial intolerance of individuals. Emphasizing individuals and classroom social settings allowed the Board to insulate in-service curriculum from civil rights conflicts occurring outside classroom walls. As David Tyack asserted, what most of these programs wanted was an "intercultural strategy that would use psychological methods to preserve civic peace, not mobilize dissidents to secure their rights." Despite the Board's recommendation that inservice instruction be used to explore "every-day problems," the schools continued to present a sterilized portrait of race that was often divorced from students' daily realities. ${ }^{43}$

In its most damaging act, the Board's decision to bar outside organizations from presenting in-service courses effectively severed the university-school symbiosis that had translated pioneering social science research into schoolroom instruction. By September 1948, these measures proved so repressive that in her capacity as supervisor of "inservice courses in intercultural education," Principal Mary Meade could find no current intercultural courses to evaluate. Responding to the dearth of intercultural study, Layle Lane, Chairman of the AFT Committee on Human Relations, observed that "progress in intercultural education work is now hampered because necessary educational materials that should be an integral part of our classroom activities are not in the hands of our

\footnotetext{
${ }^{42}$ Brotherhood Seen as U.S. Strength, The New York Times, February 21, 1949.

${ }^{43}$ Plan for Workshops In Intercultural Education, Folder 9, Series 634, Records of the NYCBOE; David Tyack, Seeking Common Ground: Public Schools in a Diverse Society (Cambridge: Harvard University Press, 2003), 81.
} 
teachers and pupils." Thus, Lane implored the Board of Superintendents to compensate for this intercultural absence by setting up committees to work on "preparation of syllabi and teaching materials, revise texts in general use, and to arrange for integration of subject matter." Rebecca Simonson, President of the Teachers Guild, also spotlighted the immediate need for intercultural plans in order to attain "valuable acceleration" for intercultural activity in the upcoming school year. In 1949, the Board of Superintendents did reverse their decision and allowed the participation of "outside organizations" that were "especially equipped" to offer courses "which are timely and meet specific curricular needs." By the Board's definition, however, "timely" courses did not include courses offered by the human rights groups, civil rights organizations, or Russian Institutes that had provided earlier instruction, but rather came from the more controlled and curated environs of "museums and botanical gardens." 44

The experience of New York Teachers Guild illustrated the difficulty in attaining Board approval for intercultural in-service courses. Since walking out of the radical New York City Teachers Union and forming the Teachers Guild, founder Henry Linville towed a conventionally acceptable line of liberal activism that stayed within the bounds of professional respectability. The Guild continued this tradition when they it tailored the aims and intent of their course, "Human Relations Can Be Taught," to specifically address the Board's newfound restrictions. Guild officials even went as far as to emulate the Board's regulatory language in their own proposal, addressing the Board's desire to have a "practical" course that "improves all phases of human relations" by billing its

\footnotetext{
${ }^{44}$ Mary Meade to William Jansen, September 22, 1948; Quotes from Layle Lane and Rebecca Simonson found in Rebecca Simonson to William Jansen, June 8, 1945, Box 9, Folder 8, Records of New York Teachers Guild; Katharine Crowe to Rebecca Simonson, May 3, 1949, Folder 8, Box 9. Records of New York Teachers Guild.
} 
seminar as a "practical course" aimed at addressing the "phases" that engender better "Human Relations." The Guild also sought to address the Board's goal for "solutions of practical every-day problems," by creating their own "practical" concept of a "democratic yardstick." Guild members maintained that the daily application of this intercultural tool would ensure equality of opportunity by prompting teachers to assess if their own pedagogical practices encouraged the "greatest amount of people" to "participate" and "benefit" from their classroom instruction. Anticipating their critics, Guild members slated vetted guest lecturers such as Rachel Dubois, Helen Trager, and Ernest Melby, whose collective expertise focused on explorations of cultural achievement and human relations that were more conventionally suited to a hyper-politicized Cold War environment. ${ }^{45}$

Despite these efforts, the Guild's campaign experienced only marginal success. After the Stern Case, the Board showed no compunction about denying course approval with little elaboration of their rationale. Lamenting how these exhaustive measures were met with often terse denials, Layle Lane noted that the Board's rejections were frustrating, especially since proposals entailed organizing an entire course, finding guest lecturers, and setting specific dates and meeting areas, only for these efforts to crumble "over a technicality." Consequently, "Human Relations Can Be Taught" only ran for one term, and even then, its "approval" was the product of bureaucratic confusion. Seeking course renewal the following term, the Guild cited the Board's positive recommendations, referenced the State Board of Education's course approval, and

\footnotetext{
${ }^{45}$ Registration for "Human Relations for the Teaching Profession," Box 11, Folder 9, Records of New York Teachers Guild; Criteria for "Teaching Human Relations," Box 11, Folder 9, Records of New York Teachers Guild; Bulletin for Human Relations Can Be Taught, Box 11, Folder 9, Records of New York Teachers Guild; Rebecca Simonson to William Jansen, April 29, 1949, Box 11, Folder 9, Records of New York Teachers Guild.
} 
included evidence attesting to the course's increasing popularity. Nevertheless, the Board refused the repetition of the course in the same week that it endorsed "Negro History Week and Brotherhood Week." Observing this seeming contradiction, one Guild member wrote, "of what avail is it to have Negro Week and National Brotherhood week if teachers can't get together in an accredited in-service course and learn the principles and practices ... in the area of human relations?" Nevertheless, these contradictions continued unabated. One anonymous teacher reported in 1951 that, "there has been no intercultural course of comparable note or interest to teachers conducted by the Board of Education." ${ }^{46}$

By the late 1940s, intercultural education had become one of the most controversial high school subjects of the post-war era. Swept up in the currents of civil rights and the Cold War, Americans came to envision intercultural activity as a democratic curriculum that united a nation, or an anti-democratic process that sowed racial disunity. As interculturalists coupled their efforts with broader civil rights struggles, they encountered what historian Thomas Sugrue believed was an "uneven playing field" where "their movements were shaped and constrained by political and economic institutions over which they often had little control." Wielding its institutional muscle, the Board frustrated its intercultural advocates, narrowed the parameters of intercultural debate, and used bureaucratic obfuscation to undercut intercultural programming. In doing so, the Board dissolved one of the largest intercultural experiments of the 1940s that involved 10,000 teachers, supervisors, and administrators.

\footnotetext{
${ }^{46}$ Layle Lane to Carol Zillman, March 1, 1949, Box 11, Folder 9, Records of New York Teachers Guild Layle Lane to William Jansen, February 2, 1948, Box 11, Folder 9, Records of New York Teachers Guild; Rebecca Simonson to William Jansen, April 28, 1948, Box 11, Folder 9, Records of New York Teachers Guild.
} 
The receding of intercultural education in New York City reflected national trends, as articles exploring racial inequality declined during the post-war years while curriculum increasingly omitted discussions of race and social equality. ${ }^{47}$

Similarly, the Board's banning of the ARI and its Russia in-service courses illustrated the extent to which containment had already pervaded Cold War educational narratives. Engaging in a shift from "world-mindedness" to education for "Cold Warmindedness," New York's schools severed their ties with the ARI in order to craft a curriculum whose defense of democratic capitalism more effectively cohered with Cold War foreign policy. As Gary Gerstle observed, the Cold War "prompted Americans to shun not only Communism but other traditions of dissent that could be construed as imperiling their nation. Thus the premium placed on political and social conformity increased during these years while the parameters of legitimate political debate narrowed." Whether talking about race, current affairs, or foreign policy, public education's new role in cultivating an "intense and defensive nationalism" led Cold War schools to tout their democratic acceptance of controversial issues while narrowing curriculum to comport with Cold War master narratives. Consequently, Board decisions increasingly reflected the politics of institutional interest while their rhetoric remained couched in the values of the public good. ${ }^{48}$

While directed democracy played a pronounced role in explorations of race and Human Relations, it played an even more significant role in the instruction of Russia and world affairs. In the late 1940s and early 1950s, Americans increasingly branded the

\footnotetext{
${ }^{47}$ Sugrue, Sweet Land of Liberty, xxiv; Burkholder, Color in the Classroom, 151.

${ }^{48}$ Hartman, Education and the Cold War, 137; Gerstle, American Crucible, 239.
} 
study of Soviet Russia and world affairs as a "controversial issue." In the subsequent discussions that followed, democratic progressives believed that allowing students to study the same global tensions fueling the Cold War would forge critically-minded pupils who could assess the conflict with a more nuanced and sobered perspective. Conversely, conservatives feared that allowing students to discuss the same controversial issues being deliberated on the world stage could ultimately expose classrooms to Communist subversion and indoctrination.

One of the more prominent examples of this debate originated from the Board of Education's "Strengthening Democracy" series, an instructional complement to the nationally endorsed Zeal for Democracy program. In "Controversial Issues: A Reexamination," Social Studies Chair Jack Estrin acknowledged that the controversial issue had evolved into the "cardinal principle of the Social Studies corpus" and emerged as the "grindstone par excellence" in sharpening the democratic rigor of America's classrooms. Yet, Estrin saw a pronounced link between the ubiquitous nature of Communist propaganda and the increasing emphasis on teaching controversial issues. In particular, Estrin argued that Russia advanced Communist-sponsored issues at the U.N. in order to pollute American minds. While controversial issues may have originated from "honest men" who held "basic differences of opinion," Estrin believed that the Cold War sparked a marked growth in Communist nations that sought to advance controversial ideas as a means to forestall America's democratic defenses. Thus, Estrin argued that the classroom tradition of teaching global events with newspapers and other material pertaining to the U.N. represented a "dangerously absurd" practice where teachers neglected to identify the presence of "Communist propaganda" in their own classrooms. 
To counteract these ideological issues, Estrin argued that teachers must now "guide through the jungle of contending ideas," by engaging in a classroom "quarantine of Communist propaganda." Whether exploring Communist-sponsored issues such as abolishing atomic weapons, prohibiting germ warfare, discussing the amelioration of human rights or race relations, or exploring a "peace pact," this required teachers to "state flatly to the class" that such controversy "does not exist" because they proceeded from "dishonest men with ulterior motives." 49

The BOE's potentially new embrace of directed democracy set an alarming precedent in educator's handling of controversial issues. Indeed, the TU believed that in seeking to narrow the parameters of controversial expression these proposals served to promote indoctrination. Critics also argued that attacking indoctrination through the suppression of academic ideas ultimately made schools complicit in the same doctrinaire process they were striving to eradicate. Furthermore, other critics took issue with American schools functioning as self-imposed arbiters of U.N deliberations. Indeed, the National Council of Social Studies indicated that it was the task of schools to "inform American youth" and "help them register opinions," and not to "indoctrinate American youth with views either favorable or unfavorable to the United Nation." Similarly, critics reminded Americans that ignoring the controversial issues that anti-communists associated with subversion, such as civil liberties, race, and control of atomic weaponry, would not engender American peace. Rather, in suppressing controversial issues to depict America as an "all-perfect and static country which meets a static all-bad Russia,"

\footnotetext{
${ }^{49}$ Reprint of Jack Estrin's "The Controversial Issue: A Re-Examination,” found in New York City Teachers Union Circular, "Shall Certain Ideas Be 'Out of Bounds.?," Box 8, Folder 3.
} 
classrooms would create the polarized misunderstandings that often precipitated global bloodshed..$^{50}$

Nevertheless, the BOE's endorsement of Estrin's article revealed the alarming rate in which directed democracy informed Cold War curriculum. Deploying democratic indoctrination to best Soviet indoctrination, lessons employing directed democracy presented a façade of democratic inquiry while laying the groundwork for ideological conformity. These ideas even informed the national "Zeal for Democracy program," which argued that Communism's ideological offensives required schools to inculcate democratic principles right "when our pupils come off the educational assembly line."51 In this sense, exercises that engaged in directed democracy suggested the extent to which containment narratives had already pervaded Cold War curriculum. Cultural scholar Alan Nadel argued in Containment Culture that containment emerged as "one of the most powerfully deployed national narratives in recorded history." In this regard, America demonstrated a surprising ability to propagate dominant narratives that grew in authority, as they aimed to unify the nation's population, codify America's claims to global authority and halt the spread of Soviet influence. Thus, the immediacy and tactical nature of America's Cold War necessitated that more questionable ideas be expunged, while the nation's more valiant deeds became foregrounded to highlight democracy's ideological supremacy. ${ }^{52}$

\footnotetext{
${ }^{50}$ Resolution of the National Council for the Social Studies found in Noteworthy Comments on Freedom of Thought and Security, Box 8, Folder 3, Records of New York City Teachers Union; 'Teacher Sees Error in Zeal for U.S. Ideas," The New York Times, July 19, 1946.

51 "Zeal for American Democracy: Education to Meet the Challenge of Totalitarianism," Samuel Wallach Papers, 6, Series III, Box 2, Folder 27. Robert F. Wagner Archive at Tamiment Library (hereafter cited as Robert Wagner Archives).

${ }^{52}$ Alan Nadel, Containment Culture: American Narratives, Postmodernism, and the Atomic Age (Durham: Duke University Press, 1995), 4.
} 
Containment also came to influence Cold War textbooks and instructional materials. In her study of post-war textbooks, Frances Fitzgerald observed how Cold War instructional materials surfaced as a particularly fertile medium for curricular containment. Indeed, Fitzgerald noted that revisionist histories reshaped America's past to the point where the nation's hallowed events appeared as urgent reminders of the heated stakes in the nation's global ideological struggle. Fitzgerald further observed that in some textbooks, "the morbid fear of Communism became an overriding passion," where the arc of American History "appears a mere prologue to the struggle with the 'Reds."' Beyond fashioning American History to the Cold War, textbooks also omitted references to discrimination and poverty while presenting the United States as a solely benevolent force in the global "struggle for democracy." One such textbook regaled, "We are too little astounded at the unprecedented virtuousness of U.S. foreign policy." Another textbook neglected to extoll the idea of liberty for its democratic virtue but rather applauded how the term's rhetorical resonance gave the United States a tactical advantage against the scourge of Soviet Communism. Thus, while the textbooks of the 1930s were "clearly the work of liberals," Cold War curriculum clearly bore the ideological imprint of post-war conservatives. ${ }^{53}$

America's embrace of directed democracy and containment enabled post-war conservatives to exert an inordinate influence on Cold War schools. Indeed, historian Marilyn Young argued that the enduring and protracted nature of Cold War conflict necessitated that post-World War II policy-makers "create a public tolerance for war as

\footnotetext{
${ }^{53}$ Fitzgerald, America Revised, 56, 115, 129.
} 
normal rather than aberrational..." ${ }^{54}$ Directed democracy fulfilled this special task, as its guided lessons portrayed the Soviet Union as a perennial adversary that haunted democracy since its inception. For example, the March 1953 issue of "Strengthening Democracy" presented a series of accepted controversial topics to be used in fulfilling the schools' commitment in discussing "appropriate controversial topics." While these questions contained instructional merit, many were often freighted with value-loaded statements aimed at fulfilling Cold War imperatives. Such questions as, "Is the passing of Stalin a blessing to mankind" predictably channeled students towards an affirmative response justified by a litany of Soviet transgressions. The question, "Is the United States too generous in giving economic aid to Europe," highlighted American kindness, while encouraging a negative response from students towards America's international benevolence. And whereas World War II caused interculturalists to assess their nation's own racist practices, Cold War teachers redirected their sights to ask if the U.N. should "take action against the Soviet Union for its policy of anti-Semitism." Whether discussing ideology, America's world role, or the Soviet Union, directed democracy ensured students gave the correct answers, by providing teachers with leading questions to ask. Altogether these efforts enabled Cold War schools to project America's democratic greatness, while advancing cohesive foreign policy narratives that sought to contain Communism's ideological influence. ${ }^{55}$

While administrators flatly that they targeted teachers who discussed Soviet Russia, anticommunists often furnished teachers Soviet explorations as evidence in their

\footnotetext{
${ }^{54}$ This excerpt from Marilyn Young's unpublished paper is cited in Mary Dudziak, War Time: An Idea, Its History, Its Consequences (New York: Oxford University Press, 2013), 92.

${ }^{55}$ Strengthening Democracy 5 (May 1953): 6. Series 664: Division of Curriculum, "Strengthening Democracy," 1948-1965, Records of NYCBOE.
} 
investigations. For example, New York music teacher Arthur Aaron ultimately encountered investigative questions for discussing how the artistic experience differed under contrasting modes of government. Whereas Aaron cited select scholarship to assert that Russian artists held a more formal relationship with Soviet regimes that produced the "material needs" for their work, investigators believed the teacher did not sufficiently elaborate upon the "limits of freedom" that totalitarianism imposed on creative endeavors. Reflecting directed democracy in action, investigators also criticized Aaron for not parsing out whether such statements reflected the observations of the artist or the views of the Soviet government as "dictated to the artist." Prior to his investigation, Brooklyn teacher Louis Jaffe also spurred a public controversy over Social Studies instruction when he charged that school textbooks were complicit in perpetuating "myths which are preparing the ideological groundwork for a war between the United States and the Soviet Union.” At a subsequent Board meeting concerning his comments, Jaffe's assertion that teachers should strive for the preservation of peace was met with administrative rebukes that "the teacher is supposed to bring up American youngsters." These occurrences led one TU teacher to note at his own investigation, that in spite of administrator's assertion that they did not seek "to mold "anti-Russian children," schools had turned into "institutions of indoctrination where students will be trained to accept unreasoning hatred for other nations." Consequently, the New York City Board of Education dismissed Aaron and Jaffe for "conduct unbecoming a teacher." 56

\footnotetext{
${ }^{56}$ Transcript of Interview with Arthur Aaron, Box 1, Folder 1, Records of New York City Teachers Union; "History Teachers Clash Over Russia," The New York Times, June 20, 1946; "Louis Jaffe Dies; Ousted Teacher," The New York Times, March 24, 1968; Fact Sheet on Phillip Horowitz, Box 10, Folder 6, Records of New York City Teachers Union
} 
The strong support thrown behind teacher dismissals and containment curriculum combined to create a nationwide "climate of fear" regarding Soviet instruction. New York's schools faced stinging reports that documented teacher's fears of discussing "vital issues of the day," including "relations with the Soviet Union." The Commissioner of Education for New York State noted how this fear escalated to college campuses, where teachers "sidetracked" unpopular opinions, especially with "questions dealing with Russia." On a national level, fears of teaching about the Soviet Union developed into a broader disdain of UNESCO's curriculum, which critics commonly conflated with "world government" and "communism." Indeed, critics believed that UNESCO curriculum threatened to propagate Communist schemes, supplant the Bill of Rights with an international human rights ideology, and in general, "step in and tell teachers how to run their schools." In response, a Pawtucket school banned its "UNESCO Thinker's Club," a Houston district withdrew its schools from consideration in the "un-American" UNESCO essay contest, and a California district suppressed a UNESCO teaching manual after public outcries proclaiming that the international organization represented a movement "greater and more dangerous than Communism." Even author R.O. Hughes faced accusations that the solitary and aptly depicted "world" found on the cover of his book, Today's World, likely served to "symbolize one world, an idea adopted by Americans striving toward world government and endorsed by the Communist Party." Consequently, any exploration of issues outside the confines of America and its erstwhile Cold War allies threated to spur recriminations for engaging in "worldly," "Communistic, or "controversial" behavior. And as one teacher indicated," it is now almost as bad to be 'controversial' as it is to be a spy or traitor. ${ }^{, 57}$

\footnotetext{
${ }^{57}$ Noteworthy Comments on Freedom of Thought and Security, Box 8, Folder 3, Records of New York
} 
Throughout post-war America, the confluence of directed democracy and containment appeared to dominate Cold War curriculum. As a result, post-war curriculum presented an image of American democracy that was consonant with the nation's larger Cold War aims. Indeed, nascent Human Relations programs avoided structural critiques of racial discrimination by focusing on the prejudice of the individual. Ultimately, these programs skirted the domestic racial issues that had tarnished America's global democratic standing by omitting discussions of Northern Jim Crow and pretending that such discriminatory practices did not exist. Similarly, Cold War classrooms largely abandoned the study of Soviet Russia and world affairs, surrendering to conservative arguments that such debate exposed vulnerable classrooms to the creeping presence of Soviet subversion and indoctrination.

In documenting these curricular transitions, historians have portrayed post-war classrooms as a compliant force that sought to mold students into the accepted image of the Cold War democratic order. These interpretations have largely portrayed the American public as willing accomplices in suppressing independent thought in order to impugn Communism and tout the nation's Cold War national consensus. Yet, the tendency to believe Cold War curricular shifts were always met with frenzied support and public enthusiasm belies the heatedly contentious nature of post-war education. Indeed, Cold War Americans did not maintain a one-dimensional interpretation of democracy but rather wrangled with rapidly evolving democratic understandings shaped by the post-war world. Thus, Americans who disagreed with the instructional climate created by directed

City Teachers Union; “Teachers Urged to View World," The New York Times, November 30, 1947; "Pressure Groups Prodding Schools To End Study of U.N," The New York Times, June 29, 1952, Robert Hutchings, "Are Our Teachers Afraid to Teach?," Look Magazine, March 9, 1954. 
democracy soon mounted an ideological counteroffensive aimed at the forces controlling Cold War curriculum and dictating what children were taught. These clashes reverberated throughout America's schools as well as the nation, as debates over what schools should teach represented larger conversations over what values American should project. How and why these curricular reformers sought to accomplish these objectives will be explored in the next chapter. 


\section{Chapter 5: Pedagogical Brinkmanship: Teaching Race and Russia in McCarthy's America}

"They are not satisfied in controlling what a teacher does and what he says. They want to decide what he should think. Even deep in his soul he is not permitted to resent the Cold War." "_-B.Z. Goldberg

At a 1948 meeting that saluted the leadership of the New York City Teachers Union, Arthur Miller, author of All My Sons and Death of a Salesman, recounted a conversation he held with twenty French critics, authors, and journalists. Responding to a ban placed on Miller's works at a New York City school, the author's French colleagues indicated that post-war France had transformed into a burgeoning literary market for books that had been censored in America. While Miller attempted to explain that the censorship of his own book had only occurred at one New York school, the Frenchmen responded that censorship in one solitary school represented "censorship in America." “They were right," Miller proclaimed, "and I was ashamed, ashamed at my naiveté, and ashamed for my country." In spite of this depressing epiphany, Miller also felt heartened that "the country was not wholly asleep while its very soul was being stolen from it." For Miller, the figure of this "opposition," which provided him "the name of Freedom at that moment," was represented by the New York City Teachers Union. ${ }^{2}$

Responding to the events depicted in Chapter 3, this chapter explores how the New York City Teachers Union and other democratic progressives fought back against the efforts to marginalize intercultural education and the study of world affairs. In the time between the Stern case, and Senator Joseph McCarthy's burgeoning anticommunist crusade, intercultural education underwent a vast transformation. While the American

\footnotetext{
${ }^{1}$ David Alison, Searchlight: An Expose of New York City Schools (New York: Teachers Center Press, 1951), 115-188.

${ }^{2}$ Alison, Searchlight: An Expose of New York City Schools, 115-116.
} 
public had been involved in educational disputes before, the Cold War amplified the tendency for Americans to approach curricular disagreements in more politically charged terms. The increasing contentiousness over Cold War education meant that educational disputes were now hashed out in the intensely combative public arena of New York's schools and communities. Despite this development, historians have marginalized the influence of educators, unionists, and the American public in their educational explorations. ${ }^{3}$ By interpreting Cold War curriculum from the view of anticommunists and educational authorities, these studies neglect to explore how Americans fought to have an increasing voice in shaping post-war curriculum. This continued separation of the American public from histories of intercultural education makes it easy to assume that the 1950s witnessed a decade of educational consensus. Bringing the public back into these disputes, however, complicates this picture by showing how Americans and fellow democratic progressives situated more radical educational programs to address the nation's domestic and international crises. As activists grounded their campaigns in democratic ideals, educational administrators often had to defer to the nation's democratic fervor and entertain educational initiatives they might have previously dismissed.

\footnotetext{
${ }^{3}$ Recent examinations of intercultural education, such as Diana Selig, Americans All: The Cultural Gifts Movement (Cambridge: Harvard University Press, 2008) and Zoe Burkholder, Color in the Classroom: How American Schools Taught Race: 1900-1954 (Oxford: Oxford University Press, 2011) largely focus on intercultural education through purview of scholars, educators, and scientists advancing the material. While this was the intent of their study the unintended consequence of this focus is the tendency to isolate the efforts of more alternative interculturalists, and to neglect the public's involvement in intercultural issues. Thus, while the decline of explorations of race and discrimination in journals and some classrooms suggest that the Cold War silenced such instructional explorations, contentious discussions of race and world culture did appear in more public and less specialized venues, such as in newspapers, Board meetings, and widely circulated union materials. This chapter builds off Clarence Taylor, Reds at the Blackboard: Communism, Civil Rights, and the New York City Teachers Union (New York: Columbia University Press, 2011) study by exploring intercultural education and world events through the actions of teacher unionists and other democratic progressives.
} 
To accomplish this, democratic progressives aligned with a slate of unionists, civil rights activists, and civic leaders to join racial equality and democratic discourse as the vital platform of a truly democratic education. Dianne Ravitch's Troubled Crusade illustrates how the post-war school's central concern of providing "equality of opportunity" for all, turned schools into "magnets of dissension" as they became targets for reformers and civil rights activists in reconstructing the post-war democratic order. ${ }^{4}$ Fashioning their rhetoric around national policy, the TU asserted that the school's sanctioning of bigoted materials contradicted the nation's recent pursuit of providing an “equality of opportunity" for all by subjecting students to racist worldviews that had historically limited the opportunities available to black citizens. These campaigns ultimately endowed the TU with an educational legitimacy that brought the TU into orbit with a variety of educational reformers and civil rights activists. Consequently, the TU reinforced their civil rights campaigns by distributing "Negro History" study guides and supplements that integrated modern scholarship that provided a more redeeming portrait of black life, while also positioning American democracy as a reformist tool in agitating for racial progress. Thus, the TU's linkage of their intercultural campaigns to a truly democratic education enabled reformers to legitimize their instructional demands by grounding their appeals in America's democratic creed. In this sense, reformers were able to galvanize public pressure against New York's schools by branding their decisions as undermining American democracy.

In other avenues, educators, civic coalitions, and grassroots coalitions fought against the growing campaigns to silence discussions of Soviet Russia and world affairs.

\footnotetext{
${ }^{4}$ Dianne Ravitch, The Troubled Crusade: American Education, 1945-1980 (New York: Basic Books, 1983), xiii.
} 
Using democracy as their banner, democratic progressives decried attempts to stifle classroom discussions of world affairs by arguing that these "anti-democratic "practices neglected to prepare analytically-minded students for the grave realities of a Cold War world. Furthermore, democratic progressives took advantage of an American nation infatuated with educational controversy by publicizing the complicity of Cold War schools in avoiding the study of Russia and world affairs. Bringing this curricular transparency to the public ultimately brought pressure upon Cold War administrators who were already undergoing one of the most severe educational crises in American history. ${ }^{5}$

The increased use of Cold War schools as an "instrument of national purpose" meant that these campaigns regarding race and world affairs were no longer confined to schoolroom walls but rather expanded into America's communities and public discourse. In this hyper-politicized Cold War climate, debates over these became an arena in which a variety of groups asserted their visions about what sort of society America should become. In New York especially, these debates "anticipated the emergence of similar trends in other parts of the country," as the "stage is larger and the confrontations are more vivid, and the issues appear in sharper focus than elsewhere." ${ }^{\prime 6}$ Thus, the stakes were heightened, as historian Joshua Freeman noted that the outcome of these campaigns determined who led "New York's institutions, what policies they pursued, and what cultural and moral values they promoted." And with the federal government's escalating involvement in post-war education, New York became the epicenter of Cold War clashes, as the acceptance of educational initiatives in a city the size of New York, threatened to

\footnotetext{
${ }^{5}$ Benjamin Fine, Our Children Are Cheated: The Crisis in American Education (New York: Henry Holt and Company, 1947).

${ }^{6}$ Dianne Ravitch, The Great School Wars, New York City, 1805-1973 (New York: Basic Books, Inc.), xiii.

${ }^{7}$ Joshua Freeman, Working Class New York: Life and Labor Since World War II,(New York: The New Press, 2000), 70.
} 
facilitate a domino effect of curricular changes elsewhere. As debates over controversial issues spurred larger conversations over foreign policy and civil rights, the shape and tenor of this ideological conflict set the stage for the Cold Culture Wars.

The fact that Cold War schools functioned as an "instrument of national purpose" and as a "magnet" to fulfill the demands of the civil rights movement meant that public education straddled contradictory roles as both promoters of democratic change and guardians of America's democratic foundation. Consequently, Cold War schools galvanized a diverse base of public attention from governmental entities and reformists who expressed an increasing interest in the topics and issues that teachers addressed in their classroom. ${ }^{8}$ It is in this context, that the rise of "controversial issues" became one of the most contentious educational terms of the post-war era. Public clashes over whether Cold War schools should serve as beacons of democratic reform or anchors of American tradition, spurred larger questions over how teachers should handle polarizing issues. In these curricular battles, conservative critics believed America's democratic promise had already been fulfilled, while activists believed it had yet to be achieved. Thus, New York's schools had to reconcile the curricular demands of traditionalists, who emphasized an unblemished view of America's democratic past, with reformists who saw an imperfect, yet promising view of America's democratic future. In this light, intercultural education garnered considerable controversy, as the discipline extracted lessons from American history, in order to cast informed assessments about the nation's contemporary struggles. As historian Julia Mickenberg observed, the 1940s witnessed an

\footnotetext{
${ }^{8}$ Joel Spring, The Sorting Machine: National Educational Policy Since 1945 (New York: Longman Publishing, 1976), 1; Dianne Ravitch, The Troubled Crusade: American Education, 1945-1980 (New York: Basic Books, 1983), xiii.
} 
occasionally hostile instructional climate that "encouraged a more conservative impulse . .. applicable to practical military imperatives," while challenging the "emphasis on independent, critical thinking and democracy fostered by progressive pedagogy and intercultural education."

In the midst of these ideological disputes, the American public rarely referred to intercultural education by its proper name, but rather lumped the instruction of race, Russia, and world events under the catch-all umbrella of "controversial issues."

Ostensibly a semantic distinction, the term carried important instructional ramifications. Previously, "controversial issues" served as a curricular signpost to denote topics that required a more balanced instructional approach. In times of repression, however, the label impinged upon teachers' autonomy by opening the classroom door to bureaucratic supervision and political meddling. Indeed, attaching "controversial" to select topics freighted such issues with a politicized stigma that served to prevent open discussion and debate. Indeed, many Cold War educators surrendered to these instructional taboos and "played it safe" by omitting discussions of controversial issues entirely. In other instances, Cold War teachers became less concerned about discussing issues of race and world affairs in their classroom and more focused on tailoring their instruction to project America's democratic achievement and nationalistic largesse. ${ }^{10}$

As controversial issues became increasingly viewed as a vehicle of subversion, directed democracy found widespread endorsement by the nation's leading political and educational thinkers. Thinkers such as William Birkhead argued that the ubiquity and effectiveness behind Soviet propaganda necessitated that democracy engage "in a

\footnotetext{
${ }^{9}$ Julia Mickenberg, Learning from the Left: Children's Literature, the Cold War, and Radical Politics in the United States (Oxford: Oxford University Press, 2006), 95.

10 "Communism Study Called Essential," The New York Times, November 25, 1951.
} 
propaganda campaign in its behalf." Advocates of this directed democracy ideal asserted that students lacked the intellectual maturity to comprehend the nuances of democracy and America's Cold War struggle. Furthermore, Dr. Robert Walker, director of the Institute of Citizenship at Kansas State College, asserted that societal distractions had made students' minds a "clutter of vague ideas," while Social Studies teacher Jack Estrin, reported that Soviet "propaganda assaults" had served to "becloud the minds of free men." Thus, directed democracy proponents asserted that schools needed to guide students through the halls of America's democratic achievement as a means to inculcate more fervent "democratic men," "specialists in resistance," and "wise and skilled defenders of free society." 11

Whereas World War II forced Americans to take stock of their democratic misdeeds, directed democracy made it appear as though such transgressions never existed. In this way, directed democracy essentially functioned as a highlight reel, spotlighting select democratic narratives, while steering students away from America's contentious past. Proclaiming that grasping democracy required a meticulous bouts of "training," advocates asserted that America's democratic heritage was "not something to be taken in six easy doses like vitamin pills," but was rather a " hard task master" that required the intellectual guidance of America's educational leadership. Consequently, directed democracy served as an instructional exercise in validating the Cold War status quo. Rarely engaging in the organic nature of critical inquiry, directed democracy led

\footnotetext{
11 "Studebaker Maps War on Communism," The New York Times, November 29, 1947; "Schools Map War on Reds' Ideology," The New York Times, October 19, 1950; Shall Certain Ideas Be "Out of Bounds," Box 27, Folder 2, Records of New York City Teachers Union; "Schools Duty Cited On Disputed Issues," The New York Times, November 24, 1950; "Teachers Warned of Anti-US World," The New York Times, March 5, 1949; "Zeal for American Democracy: Education to Meet the Challenge of Totalitarianism," Samuel Wallach Papers, 6, Series III, Box 2, Folder 27. Robert F. Wagner Archive at Tamiment Library (hereafter cited as Robert Wagner Archives).
} 
teachers to script a choreographed façade of inquiry that handled incendiary topics the "right way."

The contradictory nature of a nation that marketed its democratic pedigree while censuring select topics often manifested itself in confusing Cold War lessons. For example, subversive connotations regarding post-war explorations of race and social inequality led some instructors to craft safe, yet misguided exercises. A 1952 Daily Compass article documented how civics teacher Florence Roth engaged in a lesson on the student use of racial epithets. Frustrated at students' inability to produce "samples" of such terms, Roth urged her pupils to copy in their notebooks, "Irish Mick, Dirty Dutch, Square Head, Wop, Ginney, Greaseball, Shine, Nigger, Black Protestant, Hypocrite, Kike, Sheeney." Subsequent newspaper reports that publicized the contents of students' notebooks ultimately sparked "one of the stormiest meetings in the history" of the Bronx Parent's Association. As one parent indicated at the session, "Is this is a corrective lesson? My boy learned words he never knew before.” Nevertheless, many parents feared that militantly pushing their case toward a "successful conclusion" could be misconstrued as subversive. "A lot of us who are hottest about this," one parent indicated, "are afraid that the Board of Education is going to call us red." "13

Confusing Cold War lessons were especially prevalent in Los Angeles schools, which experienced sweeping anti-communist investigations in the early 1950s. In one Los Angeles class, a teacher who fell ill left a lesson plan for his substitute to discuss the Bill of Rights during the officially designated "Bill of Rights Week." Instead, the substitute dedicated the entire class to reading the story of "Aladdin and his wonderful

12 "School Duty Cited on Disputed Issues";

13 "She Teaches Bronx Kids What 'Not' To Say: 'Wop, Mick, Kike...," The Daily Compass, March 31, 1952. 
lamp" as he feared opening America's sacred documents up to discussion, or even interpretation, could be misconstrued as disloyal in intent. Furthermore, educators nationwide feared that exploring the Bill of Rights made classrooms vulnerable to rightsbased conversations in an era punctuated by broader civil rights struggle. In this way, the substitute's decision to scrap the lesson was perhaps legitimate, as Los Angeles schools had recently hired "former members of the FBI and military intelligence" to reconnoiter classrooms and furnish evidence for teacher investigations. ${ }^{14}$

Although historians have employed these anecdotes as curious asides in Cold War cultural histories, few studies have connected these conflicts over "controversial issues" to the nation's larger educational crises. As Life Magazine reported in their special edition, entitled "U.S. SCHOOLS: THEY FACE A CRISIS," battles over curriculum loomed large in the ideological battles waged over Cold War schools. "In the divided and distracted world of this mid-century," Life indicated, "the tough and crucial battles are being fought in that realm where all solemn issues of history are decided — man's own mind." While the fury and vigor behind these discussions may have quietly evaporated in prior eras, the schools' post-war involvement in civil rights, Cold War ideology, and democratic thought placed controversial issues at the forefront of these conversations. Thus, the American tendency to "instruct the young than to coerce the adult" politicized post-war curriculum and exposed the schools to newfound educational constituencies concerned about the values and viewpoints embedded in their child's instruction. Connecting progressive education to communism, post-war conservatives and anticommunists asserted that teachers might use controversial issues as rhetorical subterfuge for subversion and indoctrination. This led many conservatives to view

\footnotetext{
${ }^{14}$ Robert Hutchings, “Are Our Teachers Afraid to Teach?,” Look Magazine, March 9, 1954.
} 
controversial issues as an unpredictable educative process that threatened to undermine America's narrative of democracy and nationalistic progress. ${ }^{15}$

These fears spurred the creation of state laws that used concerns about propaganda in the schools as a justification for investigating American teachers. Adopted in 1949, and without the transparency of a public hearing, the Feinberg Law targeted New York's teachers by amassing lists of subversive organizations whose affiliation constituted grounds for dismissal. Although the Feinberg Law concerned teachers' membership in subversive organizations, the legislation's preamble justified the law's existence by fanning the fears of subversive classroom instruction. Indeed, the preamble asserted that the infiltration of Communist teachers into American classrooms would lead to "subversive propaganda" that would be "disseminated among children of tender years." Continuing the employ of saboteur rhetoric, the preamble argued that "such dissemination of propaganda may be and frequently is sufficiently subtle to escape detection." Historian Marjorie Heins argued that the subsequent Supreme Court decision upholding the law "had nationwide repercussions" as it argued that teachers instructed in ideologically vulnerable areas "where they shape young minds."16 Thus, the law’s ambiguous phraseology empowered the scope of teacher investigations to dissect educators' afterschool groups, classroom utterances, and curricular beliefs. Commissioner of Education Francis Spaulding attempted to deflect the law's instructional precedent by arguing that the surveillance apparatus constructed by the Feinberg Law should not dissuade educators from entering into discussions about "forms

15 "The Battle for the Mind," Life Magazine, October 16, 1950, 43; David Tyack and Larry Cuban, Tinkering Toward Utopia: A Century of Public School Reform (Cambridge: Harvard University Press, 1995), 2.

${ }^{16}$ Marjorie Heins, Priests of Our Democracy: The Supreme Court, Academic Freedom, and the AntiCommunist Purge (New York: New York University Press, 2013), 3. 
of government different from our own." Yet, despite repeated assurances that teachers could teach about political issues, educational authorities provided no guidance as to what constituted objectionable activity. ${ }^{17}$

Despite Spaulding's assertion that teachers should take "full advantage of their own privileges as citizens" and speak out on political issues, anticommunists appeared to be specifically targeting some of the most active intercultural advocates within New York's schools. Certainly the fact that some leaders and members of the TU were Communists made union members vulnerable. Since the 1930s, the New York City Teachers' Union (TU) spotlighted the inimically racist materials pervading school curriculum. While many TU members were indeed avowed Communists, their efforts went beyond mere Party doctrine, as they functioned as some of the foremost thinkers in intercultural thought and served as some of the most dedicated activists in black communities. Indeed, TU teacher Alice Citron relentlessly agitated for better conditions in black schools and spent her summer studying at University of Mexico in order to produce new material that revised the bigoted interpretations promulgated by her schoolroom materials. Another teacher, Morris Lipschitz, was chairman of an interschool council on anti-Negro prejudice and once rallied 1600 parents and children "to protest an outbreak of bigotry in the community." English teacher Phillip Horowitz operated popular afterschool "intercultural clubs that sought to foster racial understanding and combat racial prejudice." Similarly, Samuel Wallach adopted a pedagogical style that

${ }^{17}$ Celia Lewis Zitron, The New York City Teachers Union: A Story of Educational and Social Commitment, 1916-1964 (New York: Humanities Press, 1968), 212-218. 
drew on America's democratic principles and founding documents as a means to help minority students assert their rights. ${ }^{18}$

Collectively, these TU teachers spent the 1940s fighting educational bias and bigotry, charging that they ran counter to American democracy. Merging Popular Front imperatives with the teacher-citizen ideal, many of these intercultural advocates intentionally taught at under-funded black schools, and according to one observer, "were much more dedicated to teaching black children the way out of the crucible of American life than the teachers we have now." In a move that defined the city's intercultural campaigns for the next decade, New York's schools derailed these intercultural efforts and used the Feinberg law to dismiss the TU's foremost racial advocates for "conduct unbecoming a teacher." ${ }^{\prime 19}$

The seemingly selective nature of these assaults meant that the American public did not just view the Feinberg Law as an attack on teachers but also as a concerted siege on intercultural thought and controversial expression. In post-war New York, charging teachers with allegations of Communist Party membership provided teachers with safeguards to refute these claims. Yet, Superintendent William Jansen circumvented these protections by contriving charges of "insubordination and conduct unbecoming," and dismissed activist teachers for refusing to answer Jansen's often probing and investigative questions. As historian Marjorie Heins has shown, this legal ploy ultimately

\footnotetext{
${ }^{18}$ Marjorie Heins, Priests of Our Democracy: The Supreme Court, Academic Freedom, and the AntiCommunist Purge (New York: New York University Press, 2013), 77; Ruth Markowitz, My Daughter the Teacher: Jewish Teachers in the New York City Schools (Rutgers University Press: New Brunswick, 1993), 164-166; Petition in support of Morris Lipschitz, Box 84, Folder 2, Records of New York City Teachers Union; Fact Sheet on Phillip Horowitz, Box 10, Folder 6, Records of New York City Teachers Union; Statement by Samuel Wallach to his Colleagues in Franklin K. Lane High School, Box 23, Folder 4, Records of New York City Teachers Union. ${ }^{19}$ Mark Naison, Communists in Harlem During the Great Depression (Chicago: University of Illinois Press, 1983), 216; Zitron, The New York City Teachers Union, 231, 240.
} 
enabled Jansen and his attorneys to engage in a more selective targeting of New York teachers. ${ }^{20}$ The New York Age echoed these thoughts, reporting that anticommunists appeared to direct their "axe" towards those teachers who "have been active in fighting against discrimination and for school improvements among minority groups." At his own interrogation, TU Teacher Philip Horowitz noted how the Board's dissolution of inservice courses commenced a "vicious attack that is being made against intercultural activities." Surveys nationwide reported that instructional explorations of race proved as controversial as classroom discussions on Communism and the Soviet Union.

Documenting the "removal of the race concept," historian Zoe Burkholder observed how the Cold War years witnessed a "noticeable decline in the numbers of articles on teaching racial tolerance," and an increase in Human Relations programs that preached ambiguous ideas of "brotherhood" and "neighborliness." With civil rights battles occurring outside schoolroom walls, anticommunists appeared to be barricading the schools from rightsbased conversations by silencing more radical strains of intercultural thought. ${ }^{21}$

Historians documenting these transformations portray intercultural influence as withering under these pernicious waves of anticommunist repression. As the story goes, intercultural enthusiasm was cowed into submission, supplanted by Human Relations programs that obscured more searing racial critiques by focusing on the intolerance of the individual. With intercultural programs dismantled, its practitioners dismissed, and the

\footnotetext{
${ }^{20}$ Heins, Priests of Our Democracy, 94.

${ }^{21}$ Excerpt from New York Age article found in Who is Loyal to Our Children, Dr. Jansen?, Box 10, Folder 6, Records of New York City Teachers Union; Transcript of Interview with Mr. Philip Horowitz, Teacher, Seward Park High School, Box 10, Folder 6, Records of New York City Teachers Union; Burkholder, Color in the Classroom, 151-156.
} 
movement stigmatized, McCarthyism was thought to be too much for radical intercultural campaigns sustained by educational support and scholarly contribution. ${ }^{22}$

Yet, New York's interculturalists and democratic progressives did not relent in the face of McCarthyism, but rather repurposed their World War intercultural campaigns to address the Cold War's newfound imperatives. During World War II, intercultural education garnered widespread acclaim from alarmists who feared Hitler's racist worldviews had already invaded the nation's schools and reached America's children. Unlike Nazi Germany, however, the Soviet Union did not project an inimically racist worldview, but rather spotlighted America's racial conflict as a testament to democracy's ideological failure. America's federal government responded to these attacks by marketing a narrative of race and American democracy that maintained "democracy was a form of government that made the achievement of social justice possible and that democratic change, however slow and gradual, was superior to dictatorial imposition." Directed democracy and Human Relations reinforced these campaigns by circumventing America's embattled racial past, and avoiding discussions of institutional racism by focusing on the bigotry of the individual. Thus, New York's schools provided a seeming contrast to racial conflict, presenting serene images of students engaging in interracial cooperation, learning about minority group achievement, and reorienting their cultural

\footnotetext{
${ }^{22}$ Among these works, Ruth Markowitz, My Daughter the Teacher, offers a victim-centric examination that notes the TU's initial intercultural achievements while obscuring their more radical campaigns spawned after the union's repression. Similarly, Zoe Burkholder, Color in the Classroom, pinpoints the tandem of Cold War and anticommunism as leading to a "removal of the race concept" and Human Relations programs gave "rise of the colorblind ideal." Diana Selig, Americans All, similarly stresses how the postwar period facilitated an emphasis on intergroup relations while fewer interculturalists explored issues of race and class.
} 
perceptions and biases. If America's promise was with its children, democracy appeared to be unlocking the interracial potential of America's youth. ${ }^{23}$

While tales of racial progress provided America with tactical narratives of democracy's moral superiority, the more physical images of racial discrimination exposed America's most vulnerable ideological flank. It is in this way, that the story of post-war intercultural education proves Mary Dudziak's assertion that the Cold War "gave rise to new opportunities for those who could exploit Cold War anxieties, while yet remaining within the bounds of acceptable Americanism." Indeed, the TU maximized these "opportunities" by binding ideals of social justice and racial equality to Cold War narratives of racial progress. Fashioning their rhetoric around national policy, the TU asserted that the school's sanctioning of bigoted materials contradicted the nation's recent pursuit of providing an "equality of opportunity" for all by subjecting students to racist worldviews that had historically limited the opportunities available to black citizens. Highlighting the abundant presence of these racist materials within New York's schools rationalized the TU's argument for the reintroduction of more scientific views on race, which had fallen out of disfavor, yet provided more redeemable racial assessments. Subsequently, the TU circulated Negro History Supplements and "study guides" that deliberately reframed modern scholarship to address the emerging civil rights movement. Situating these intercultural campaigns as an embodiment of America's democratic promise, the TU helped normalize discussions of race and equality while galvanizing a broad base of adherents and public support. To many New Yorkers, these campaigns made issues of race and equality a required topic for Cold War instruction. And to historian Clarence Taylor, the scope and tenacity of these intercultural campaigns, "throw

${ }^{23}$ Dudziak, Cold War, Civil Rights, 6-13, 15. 
into question the argument that popular front unionism in New York City was eradicated during the civil rights struggles of the post war period."24

The TU's 1950 report, Bias and Prejudice in Textbooks In Use In New York City Schools, encapsulated the union's ability to surmount the struggles of anticommunism and ramify discussions of race into New York's schools and communities. Released a year after the Feinberg Law, Bias and Prejudice surveyed the anti-democratic materials in New York's textbooks “distorted pictures of racial and other minorities," served to "poison the well-springs of our democratic heritage." Aware of the Communist stigma associated with their union as well as intercultural education, the TU launched Bias and Prejudice by noting their report was not a fringe political investigation but rather an evolution of "numerous studies" that since 1939, "provided serious and detailed criticism" that had been ignored by the "educational authorities of New York City." As a testament to its successful formula, the report remained in "immediate and continuing demand" from teachers, libraries, universities, parents, college students, and teachertraining institutions. ${ }^{25}$

Perhaps Bias and Prejudice's most damning contribution was its methodical documentation of textbook authors' adoption of the racist views of Columbia historian William Dunning. A train of historical thought launched in the 1890s, the Dunning school interpreted Reconstruction as an era of tragedy where Southerners, who after graciously accepting Civil War defeat, were thrust into political and social humiliation by an overbearing North. Subsequent Reconstruction governments, according to Dunning,

\footnotetext{
${ }^{24}$ Dudziak, Cold War, Civil Rights, 15; Clarence Taylor, Reds at the Blackboard: Communism, Civil Rights, and the New York City Teachers Union (New York: Columbia University Press, 2011), 238.

${ }^{25}$ Teachers' Union, Bias and Prejudice in Textbooks in Use in New York City Schools, an Indictment, 1950, Box 2, Folder 6, Records of New York City Teachers Union.
} 
bequeathed an unparalleled amount of political and economic power to a black caste that lacked the capacity for self-government. Dunning's adherents explained that black's deprivation and loss of political and economic rights after Reconstruction stemmed from their racial inferiority that meant blacks should never "be integrated into American society on an equal planes with whites." Although the Dunning school predominantly focused on Reconstruction, slavery's inextricable link to the post-Civil War period meant that black slaves were largely portrayed as carefree yet untrustworthy laborers who required the guidance of a kindly and paternalistic planter class. And while these views pervaded the academy throughout the 1930s, perhaps most toxic was that these interpretations "persisted into the 1960s in northern high schools." 26

By spotlighting the presence of nineteenth century racist ideologies in school textbooks, the TU portrayed New York City's schools as an anti-democratic haven that irrevocably marred the "democratic spirit of their children." The TU began its report by highlighting the presence of racist depictions of slavery in textbooks, most of which had been either approved or authored by key administrators in New York City's School System. Indeed, many of these textbooks portrayed slavery as a largely innocuous system that posed numerous benefits, especially compared to the economic unpredictability of a rapidly industrialized North. High school textbook The United States in the Making, authored by Leon Canfield, Howard Wilder, Fredric Paxson, Ellis Merton Coulter, and Nelson Mead, indicated that, "On the whole the slaves of the South were considerately treated ... They probably did not work any harder than the northern 'hired man', and at least they had fewer worries than about unemployment and the insecurity of old age."

\footnotetext{
26 “The Reconstruction Era: How Large Its Scope?" in Interpretations of American History: Through Reconstruction, ed.. Francis G. Couvares et al. (Boston: Bedford St. Martin's, 2009), 347-349.
} 
Glenn Moon's textbook, Story of Our Land and People, echoed these paternalistic sentiments indicating, "His (the slave's life) was safe; his master must care for him in sickness, and provide for him when he was too old for labor. Most of the Negroes who grew up as slaves were content with their lot, being well treated and having no fear of poverty or old age. ${ }^{27}$

The TU further noted how textbooks supplemented their portrait of slaveholder benevolence by minimalizing the harsh violence meted out to black slaves. According to the History of the U.S. Unit Plan, authored by W.H. Yarbrough and Clarence Bruner, the planter had the holistic awareness akin to an "animal trainer" who could get the "best results through kind treatment." New York Assistant Superintendent William Hamm's textbook, The American Story, acknowledged the violence of slavery while normalizing the institution, indicating that conventional methods of punishing a slave "was not thought cruel," as white children were "frequently whipped by their parents and schoolteachers." Assuaging reader's concerns, Hamm indicated that even "white sailors in the navy and merchant marine were whipped.” The report also revealed how Ralph Harlow's 1947 textbook, Story of America, rationalized slave punishment as "Negroes had to be encouraged to work because many of them were irresponsible, if not lazy." Continuing this rationalization, another approved textbook argued that the "slave usually was not a good worker; he lacked initiative and supervision, and interest, and required much supervision.”

In highlighting textbooks that legitimized antebellum slavery, the TU emphasized the complicity of New York's schools in endorsing a "benign image of slavery that was

\footnotetext{
${ }^{27}$ Teachers' Union, Bias and Prejudice in Textbooks in Use in New York City Schools, an Indictment, 1950, Box 2, Folder 6, Records of New York City Teachers Union.
} 
symptomatic of the larger problem of institutional racism in the North." ${ }^{28}$ Abundantly documented throughout the report, were positive depictions of slavery in the textbooks, including sentences such as "It was often a happy life for the slaves," and "When the master was kind, these black people lived very happy lives." Indeed, Bias and Prejudice illuminated how New York's textbook's explicitly perpetuated black stereotypes, such as the "fat black mammies" and the "lazy, banjo-strumming, watermelon-eating slave," which exposed "millions of our children" to dehumanizing caricatures while running counter to New York's own Human Relations programs. Pondering the psychological impact of such works, years before such arguments informed the Brown decision to desegregate schools, the report queried, "Is it any wonder, then, that children think of the Negro as caricature and stereotype when text after text, many written by our educational officials, systematically cultivate these conceptions?" Indeed, the TU wondered how such racist material proliferated when there existed an abundance of scholarship that offered a more fair and thoughtful rendering of American slavery. "They might have examined the advertisements for runaway slaves and been impressed by the description of the scars," the report asserted, or "they might have examined court records and received some inkling of the devious methods of exonerating slave-owners who did their slaves to death." Furthermore, Bias and Prejudice argued that administrators' inability to choose between two staunchly differentiated interpretations, one enlightened and one "undemocratic," effectively called into question how New York's educational authorities could function as the sole arbiters in shaping intercultural thought and dismissing intercultural teachers. "It is clear that many of our highest educational officials," the report indicated, "cannot assume a mask of impartiality in determining the value of

${ }^{28}$ Taylor, Reds at the Blackboard, 242. 
instructional materials since they demonstrate a definite bias themselves." To the TU, such actions were "undemocratic" and potentially treasonous as they sanctioned the spread of white supremacy while sabotaging America's national commitment to equal opportunity. ${ }^{29}$

By focusing on the complicity of New York's schools in sanctioning racist material, the TU reinforced their calls for schools to adopt more contemporary scholarship that revised the dangerously outmoded views of blacks and American slavery. With intercultural in-service courses now dismantled by New York's anticommunists, the TU found a way to renew the scholar-teacher symbiosis by circulating their own intercultural material, which distilled more innovative historiographies into study guides for teachers to create their own lessons and unit plans. Informed by the work of early writers like Herbert Aptheker and John Hope Franklin, these materials specifically sought to rebuke the Dunning school and its impact on Northern textbooks by realizing W.E.B. DuBois' assertion that 'No serious and unbiased student can be deceived by the fairy tale of a beautiful Southern slave civilization." In particular, the study guide, "Negro Slavery in the United States," found depictions of black slaves as bumbling agrarian laborers—devoid of any skills or initiative—especially disconcerting. TU member Alice Citron, a key figure in the union's intercultural campaigns, insisted that the presence of such "outright bias and prejudice" within American history endowed African-American children with stultifying notions "that they are inferior." Activist Loraine Hansberry echoed these concerns indicating, "From the time he is born the Negro child is surrounded by a society organized to convince him that

\footnotetext{
${ }^{29}$ Teachers' Union, Bias and Prejudice in Textbooks in Use in New York City Schools, an Indictment, 1950, Box 2, Folder 6, Records of New York City Teachers Union.
} 
he belongs to a people with a past so worthless and shameful that it amounts to no past at all. ${ }^{30}$

In response to such distorted portrayals, the "Negro Slavery" study guide sought to realize Citron's argument that African-Americans must know "they are people," by spotlighting instances where slaves used their abilities to carve out a measure of autonomy and rights. The guide noted that in spite of the dehumanizing conditions wrought by slavery, blacks achieved a myriad of accomplishments, pointing to Henry Blair who "received patents for the invention of two corn harvesters," while Dr. James Derhman "bought his freedom and developed a successful practice" after learning "medicine from his doctor-owner." The study guide also contested the idea of slaves serving as unskilled laborers and simple-minded farmhands by noting that "skilled slaves were often leased out to work in the factories and in other establishments," where they worked in iron furnaces, served as machine operators, and functioned as caulkers in shipyards. Connecting such skills to liberation, the guide noted how some slaves used the wages gleaned from their abilities to "purchase their own freedom." Appealing to the Cold War's hyper-zealous focus on the Founding Fathers, the guide revealed that Thomas Jefferson and George Washington entrusted "negro workmen" with the construction of their homes. These developments were not limited to the North, but rather transcended into the agrarian South as slave-owners instructed blacks in skilled trades such as masonry, plastering, and tailoring, while slaves also engaged in more "artistic" expressions such as woodcarving, gardening, and elaborate iron work. The supplement noted that these seemingly conventional accomplishments proved especially admirable in

\footnotetext{
${ }^{30}$ Ibid; Harlem Committee, Negro Slavery in the United States, 1800-1865, Box 44, Folder 11, Records of New York City Teachers Union; Lorraine Hansberry, "Life Challenges Negro Youth," Freedom 5, no. 3 (March 1955), 7.
} 
light of a slave system that strove to deprive blacks of every "opportunity to develop initiatives, to carry responsibility, and to stand on their own feet as equal human beings." ${ }^{31}$

While these accounts provided a more optimistic rendering of slave accomplishment, the study guide also sought to combat established views that "slaves were happy and secure under slavery.” Responding to contemporary intercultural programs that avoided issues of slavery to stress the primacy of human relations and black culture, the study guide noted how slavery eradicated "human relationships" and contributed to a degradation of black culture by dissolving the bonds of familial and tribal units. These measures--designed by slaveholders to compel obedience by eradicating unity--meant that slave mothers sometimes "killed her children or mutilated them or herself or her husband" in order to resist the "sale" and subsequent "division" of her family. Ultimately, the guide documented the futility of such efforts by presenting a genuine portrait of the slave market rarely found in any $20^{\text {th }}$ century instructional materials:

Negro slaves were considered pieces of property to be sold as one would sell cattle, cart wheels, or bedsteads. In preparation for sale their hair was dyed and their bodies greased to make them appear younger. On the auction block every element of human decency was violated. The slaves were given a most rigorous scrutiny.

The study guide also criticized textbooks that minimalized or normalized whipping, by noting that "continual cruelty was most common," and that "regardless of the cost in human life," slaveholders doled out punishment as a means to incentivize laborers to produce the "maximum amount of crops." Thus, the guide refuted Dunning's assertion

${ }^{31}$ Markowitz, My Daughter the Teacher, 164;Harlem Committee, Negro Slavery in the United States, 1800-1865, Box 44, Folder 11, Records of New York City Teachers Union 
that slavery constituted a more humane institution by portraying the system as a "business proposition," which ultimately generated the wealth for "many first families of New England" while providing much of the "capital” for England's own Industrial Revolution. $^{32}$

By pitting more modern views of slavery against racist textbooks, the TU was able to argue that distorted images of black history were as toxic to black students as contemporary racial stereotypes. Thus, Bias and Prejudice effectively documented the irony of schools that perpetuated undemocratic stereotypes in their textbooks while creating Human Relations programs that sought to discredit these very same caricatures. Furthermore, the report exposed the contradiction of a school system that endorsed racially divisive textbooks while dismantling intercultural programs for stoking "disunity." Placing the onus for racial disunity on the schools, the union fought against the repression of intercultural education. It used the existence of such racist materials to mount a renewed call for the innovative yet suppressed historical scholarship that once found widespread acceptance during World War II. This legitimized the TU's claim that the incorporating contemporary historical scholarship could provide the solution in reconciling the school's racially fractured, and even controversial, instructional affairs.

While the TU argued that distortions of American slavery psychologically impaired black's own self-image, the union proposed that racist depictions of Reconstruction inhibited blacks contemporary struggles for civil rights and racial equality. Historian Herbert Aptheker argued that negative portrayals of black political participation during Reconstruction served witting political ends, as denying African

\footnotetext{
${ }^{32}$ Teachers' Union, Bias and Prejudice in Textbooks in Use in New York City Schools, an Indictment, 1950, Box 2, Folder 6, Records of New York City Teachers Union; Harlem Committee, Negro Slavery in the United States, 1800-1865, Box 44, Folder 11, Records of New York City Teachers Union
} 
Americans an "inspiring past worth of study and emulation weakens them and their allies in the present-day efforts for equality and freedom." Indeed, directed democracy, and its curricular accomplices of Human Relations and cultural gifts, effectively insulated the schools from both historical and contemporary discussions of civil rights and racial equality. While Human Relations avoided discussions of civil rights by focusing on interracial interactions of the individual, cultural studies of race circumvented the nation's legacy of racial discrimination by highlighting examples of black achievement. Thus, directed democracy perpetuated the trend of outmoded black history's to engage in "great sins of omission and distortion," as tales of historical and contemporary quests for racial equality largely evaporated under the need to burnish the nation's racial legacy, while also keeping African-Americans "in their place." Deprived from learning the history of their own racial struggles, leftists believed, African-Americans thus lacked the reference points and ideological framework to perceive of their broader campaigns for civil rights and racial equality. Thus, the TU's intercultural campaigns reflected Aptheker's assertion that propagating the correct views regarding Reconstruction played a vital role, as "to rescue the Negro's past from oblivion and distortion is to arm for today’s struggle." 33

With these convictions in mind, Bias and Prejudice documented textbooks that contained racist and belittling views of black Reconstruction. While some textbooks noted that slaves believed freedom meant "no more work" and "one long vacation," other materials noted that the elevation of the "ignorant Negro to political power" created a palpable sense of "great disorder." Other textbooks maintained that black's intellectual

\footnotetext{
${ }^{33}$ Herbert Aptheker, "Negro History: An Arsenal for Liberation," The New Masses, February 11, 1947, 812.
} 
inferiority and inherent incapacity for political governance led black politicians to defer to the ideas of "rascally politicians who came down from the North." After swiftly assuming political power, black leaders initiated the degradation "of the older leaders of the South," who effectively represented "the only people who could help them to get a start in their new life of freedom.” A spate of textbooks authored by New York administrators ultimately legitimized the subsequent creation of the Ku Klan Klan, arguing that "men of property and intelligence," who were "deprived of their homes, bankrupt, and terrorized by Negroes," ultimately resorted to "violence when other methods failed." "Its purposes were patriotic," textbooks noted, as "it was natural that the Southern whites, to prevent their complete ruin should wish to regain control of their own states." 34

Interpreting Reconstruction as a watershed moment for race and American democracy, the TU sought to revise these historical fallacies that they saw as becoming "accepted historical fact." Informed by the scholarship of W.E.B. DuBois, John Hope Franklin, and Carter Woodson, the TU's "Reconstruction" pamphlet deployed contemporary retellings of the period as a means to rebuke racist histories while also spotlighting black's transcendent and centuries long quest for political equality. Drawing a straight line from Reconstruction to contemporary civil rights struggles, the pamphlet framed these events as chronologically distinct eras shaped by similar quests for equality and contested by indistinguishable beliefs in white supremacy. For example, the pamphlet dissected the myth of "black buffoons in legislatures" and "golden spittoons for field hands" by outlining the legislative achievements accorded by black politicians and

\footnotetext{
${ }^{34}$ Teachers' Union, Bias and Prejudice in Textbooks in Use in New York City Schools, an Indictment, 1950, Box 2, Folder 6, Records of New York City Teachers Union.
} 
Reconstruction-era governments. In a seemingly deliberate contrast to Jim Crow of the 1950s, the report noted how Reconstruction governments initiated a "great advance for the South" by abolishing discrimination based on race, endowing full civil and political rights to African-Americans, and installing provisions for unsegregated schools. Reconstruction governments, the report indicated, also embraced a more robust and empowered interpretation of American democracy, as they enlarged the rights of women, installed local governments predicated on the basis of popular elections, placed the realm of the judiciary under popular control, and in a move that enfranchised "poor whites as well as Negroes," abolished property qualifications for voting and holding political office. Altogether, these accounts provided a stark contrast to textbooks that often neglected to point out racial segregation in education, and black's inability to vote. Thus, they interpreted Reconstruction-era governments as positive examples of American democracy that stood in stark contrast to the repressively undemocratic government of the antebellum. ${ }^{35}$

Revealing the sheer breadth of these legislative accomplishment's illustrated that the South's $19^{\text {th }}$ century political struggles did not stem from the incompetency of "Negro rule," as many racist histories suggested but rather from the discriminatory barriers installed by the "Southern ruling class" to the "great detriment of the South." Throughout the report, the TU abundantly documented how the imposition of black codes, the extralegal violence and intimidation visited by the Ku Klux Klan, and the South's near unanimous rejection of the $14^{\text {th }}$ Amendment epitomized the regions unbending commitment to reinstating the ascendancy of white rule. Consequently, the pamphlet

\footnotetext{
${ }^{35}$ Harlem Committee, Reconstruction, January 12, 1951, Box 44, Folder 8, Records of the New York City Teachers Union.
} 
presented an empowering yet stark image of Reconstruction, where optimistic tales of black advancement were often tempered by Southerner's desire to regain political control and consign blacks to "complete subjugation." 36

Whereas the Reconstruction study guide provided an optimistic yet depressing tale of racial equality that was almost achieved, other study guides illustrated how blacks had historically fought to contest and surmount these racial barriers. As early as 1939, the National Association for the Advancement of Colored People (NAACP) lamented the "incalculable harm" of histories that concealed the resistance of heroic black figures. The NAACP believed these histories proved especially pernicious, as they obscured how black's resisted against racist structures that sought to keep them "in the most inarticulate condition to prevent their rising up to break their chains. ${ }^{{ }^{37}}$ In response to this critique, the TU released study guides that not only lodged black's transcendent fight for equality within America's iconic historical events, but also documented the successful methods blacks employed in their racial struggles. For example, "The Negro In New York" study guide documented the multiple "means of struggle" African-Americans employed in their quest "toward equal rights." Documenting the resistance of "the largest Negro community of any city in the world," the guide argued that the black church served as a vital conduit for black empowerment, as it "furnished a meeting place and platform for the anti-slavery struggle," while also "developing strong and intelligent leaders." In terms of education, the guide observed how benevolent and cultural groups served as vital agencies for the creation, improvement, and expansion of blacks schools. Furthermore,

\footnotetext{
${ }^{36}$ Harlem Committee, Reconstruction, January 12, 1951, Box 44, Folder 8, Records of the New York City Teachers Union.

${ }^{37}$ Teachers' Union, Bias and Prejudice in Textbooks in Use in New York City Schools, an Indictment, 1950, Box 2, Folder 6, Records of New York City Teachers Union.
} 
the guide connected the importance of education to such empowering avenues as the "Negro press," illustrating how the abolitionist organ North Star carried an immense influence that even elicited transnational correspondence with "Europe and the West Indies." Lastly, the pamphlet underscored the power of black organization and "protest groups" in pressuring for political power and inducing white concessions. Throughout the study, the TU methodically described the sheer power and diversity of black protest, as African-Americans employed grassroots organization to combat black violence, assist fugitive slaves, prevent black kidnappings, and unify audiences against slavery. ${ }^{38}$

While the "Negro in New York" study guide detailed the myriad of strategies blacks employed to attain equality, the "Negro in the American Revolution" spotlighted valiant black figures who employed such means in one of America's most romanticized historical conflicts. In her study of post-war textbooks, Frances Fitzgerald noted how the histories of the 1950s portrayed America as "the greatest nation in the world," whose superior institutions ensured that the country's infallible values "remained constant from the time of the American Revolution.. ${ }^{39}$ This political and moral constancy was often achieved by isolating African-Americans quest for equality from the country's iconic events. As the NAACP study in its survey of school textbooks observed, "nowhere in these books do you find the true story of the heroic roles" played by black figures." "The Negro in the American Revolution" sought to challenge this "conspiracy of silence," by lodging blacks fight for equality within the event that secured America its independence. In doing so, it illustrated how the Revolution's potential promise of black liberation

\footnotetext{
${ }^{38}$ Teachers Union, The Negro in New York: 1626-1865, November 1955, Box 44, Folder 7, Records of New York City Teachers Union.

${ }^{39}$ Frances Fitzgerald, America Revised: What History Textbooks Have Taught Our Children About Their Country, And How and Why Those Textbooks Have Changed in Different Decades (New York: Random House, 1979), 10.
} 
animated the efforts of blacks who played key roles in securing the victories of the American Revolution. At the outset, the guide noted how 5,000 African-Americans "rushed forward" to enlist in the American Revolution because "of its promise of liberty and equality." Written only a few years after Truman's desegregation of the armed forces, the study guide demonstrated that African-Americans "fought side by side with white soldiers," as the Navy "did not have any Jim Crow policy toward the Negroes." This pronounced racial egalitarianism, the guide claimed, meant that blacks participated in the Revolution's most iconic conflicts, even altering the fate of many battles. Throughout the study guide, the TU documented the acts of a "negro minuteman" who stopped an advance at Bunker Hill, noted how two African-Americans fought Washington when he crossed the Delaware, and illustrated how Haitians fought in the Revolution and helped repel the British during the "siege of Savannah." The American Revolution also had a "Negro Molly Pitcher," the guide indicated, as Deborah Gannet enlisted by disguising her gender and serving under the coded name of Robert Shurliff. Thus, the guide noted how slaves during the Revolution sought to achieve freedom "through any means." This included petitioning legislatures for their liberation, fomenting slave insurrections, and suing courts for their freedom. ${ }^{40}$

Collectively, Bias and Prejudice and the TU's black history guides advanced a massive indictment of the racist materials informing New York's school curriculum. The study guides and bibliographies, which were circulated to parents, grassroots coalitions, and educators, placed the distilled findings of new and innovative historical scholarship into the hands of TU teachers, who commonly taught at black schools. Although these

\footnotetext{
${ }^{40}$ Harlem Committee, The Negro in the American Revolution, May 1951, Box 44, Folder 8, Records of New York City Teachers Union.
} 
guides appeared to condemn American democracy, the TU anticipated their critics by drawing a firm distinction between the more authoritarian stylings of Southern rule and America's democratic penchant for reform. Throughout each study guide, the TU emphasized how blacks used the redeeming and transformative promise of America's most iconic events in order to fight for their freedom and secure racial equality. In this way, the fight for civil rights was not portrayed as new or anomalistic, but rather a crusade that sought to redeem the democratic guarantees bestowed by America since its foundation. Thrust against the backdrop of the American Revolution, Civil War, and Reconstruction, contemporary fights for social justice and equality thus appeared as a natural evolution of the struggles blacks waged almost centuries before. The TU's alignment of these historical narratives with contemporary civil rights struggles ultimately enabled the union to place black resistance within a broader continuum that merged black's historical realities with their contemporary world. The reports even made periodic appeals to the hyper-patriotism wrought by the Cold War, highlighting how America's many of America's Founders "fought against this old and still existent argument" of black inferiority ${ }^{41}$ While historian Thomas Sugrue argued "White educators had deprived black students of their own past," these materials realized Herbert Aptheker's assertion that black history could "serve as a weapon of incalculable power in our present critical period when each man must stand up and be counted." ${ }^{\prime 2}$

Bias and Prejudice also made substantive strides in advancing intercultural thought while placing political pressure upon New York's schools. Concomitant with the push for civil rights was also the desire to combat the psychological degradation inflicted

\footnotetext{
${ }^{41}$ Harlem Committee, The Negro in the American Revolution, May 1951, Box 44, Folder 8, Records of New York City Teachers Union.

${ }^{42}$ Sugrue, Sweet Land of Liberty, 472; Aptheker, "Negro History: An Arsenal for Liberation," 12.
} 
by racist school curriculum. Portraying racist curriculum as an anti-democratic breach of the nation's post-war values, Bias and Prejudice argued that New York's schools failed in their newfound roles as guardians of equality of opportunity. Furthermore, the twentysix-page report abundantly documented how New York's schools violated their own Human Relations programs by heaping "insults" upon millions of our children, which disgraced "all democratic conceptions of education." With slaves depicted as an "inert, spineless, depraved mass," African-Americans portrayed as "shiftless, irresponsible, chicken-stealing Negroes," and the rise of black politics analyzed with "an orgy of negrobaiting" that rapidly fueled the "fulminations of the most rabid advocate of white supremacy," these textbooks animated a wave of public outrage and spurred the involvement of the New York's grassroots coalitions. In 1950, a coalition of parents sent an open letter to the Board of Education, asserting that the presence of "anti-democratic texts in the hands of our children" ultimately contradicted school officials who "frequently made declarations of the importance of teaching brotherhood and interracial understanding." Albert Pezzati, 1940 American Labor Party candidate, noted "the impact on American democracy of such texts," and assailed the board for being a complicit "party to the pollution of the minds that you are supposed to nurture." Leon Straus, representative of the Fur Dressers and Dyers Union, alerted Superintendent Jansen that locals ultimately comprising "seventy-five hundred union members" supported a unanimous resolution urging for the Board's removal of biased textbooks. ${ }^{43}$

This wave of public pressure, seemingly emanating from all corners of the public interest, ultimately induced key concessions from New York's Board of Education.

\footnotetext{
${ }^{43}$ Teachers' Union, Bias and Prejudice in Textbooks in Use in New York City Schools, an Indictment, 1950, Box 2, Folder 6, Records of New York City Teachers Union; Taylor, Reds at the Blackboard, 244-250.
} 
Although the Timone Resolution barred the TU from negotiating or even addressing the Board, Board President Maximillian Moss requested that the TU send material to the school's official Instructional Affairs Committee that corroborated their claims of biased and prejudicial phrases. By 1952, the Board's Committee on Instructional Affairs removed several books with racist content. As historian Clarence Taylor noted, "Bias and Prejudice was not merely a fact-finding report but also a political document designed to weaken Jansen's position and bolster the image of the union." Indeed, Bias and Prejudice ultimately highlighted the fundamental contradictions between the Board's democratic proclamations and their curricular endorsements. In doing so, this "political document" enabled a beleaguered and impaired union to induce curricular concessions while espousing a more modern and radical interpretation of black history, a significant accomplishment in a Cold War climate prone towards repressing dissent and narrowing intercultural discourse. ${ }^{44}$

While the TU deployed black history to agitate for social justice and racial equality, its "Negro History" circulars mounted more contemporary assessments of civil rights and racial discrimination. Historian Jonathan Zimmerman has argued that campaigns to diversify historical instruction have commonly enhanced the "patriotic" components of historical curriculum while rarely contesting the conventional boundaries of accepted historical narratives. ${ }^{45}$ Yet, the TU's "Negro History" supplements effectively championed the historical designs of founder Carter Woodson, while calling upon American to realize its Cold War master narratives of social justice and racial progress. The supplements accomplished this by echoing the designs of more radical

\footnotetext{
${ }^{44}$ Taylor, Reds at the Blackboard, 244-250.

${ }^{45}$ Jonathan Zimmerman, Whose America?: Culture Wars in the Public Schools (Cambridge: Harvard University Press, 2002), 8.
} 
racial critics who called upon a black history that revealed the "lessons of the past" in order to "throw inspiring light of the problems of the present." 46 Throughout the pages of the "Negro History" circulars, the TU charted the combative relationship between racial discrimination and social equality by blurring the lines between blacks' discriminatory past and their contemporary civil rights struggles. While these materials seemingly critiqued American democracy, the TU argued that its materials fulfilled the stated objectives of New York's schools to instill a "pride and faith in American democracy and respect for the dignity and work of individuals and peoples, regardless of race, religion, nationality, or socio-economic status." With conventional Negro History celebrations spotlighting black culture and achievement, and Communists calling upon the field to expose how America manipulated blacks to "whip up anti-Sovietism and dissipate the mass struggle for Negro rights," the TU's approach straddled a firmly identifiable middle ground that addressed the nation's legacy of racial democracy while echoing a belief in democracy's reformist ability to rectify societal ills. ${ }^{47}$

The TU employed this approach in their exploration of structural racism within New York and the country at large. Throughout the pages of their Negro History supplements, the TU replaced more static portraits of structural racism and individual bias with more fluidly democratic depictions of an American nation evolving to meet the demands of civil rights struggles. The article, "Negroes and the Labor Movement," illustrated how Jim Crow inhibited black unionization by barring blacks from most trades and consigning them to menial jobs. Yet, the guide noted that World War I's

\footnotetext{
${ }^{46}$ The New York State Communist Party, Negro History Week: 1950, Folder 1, Series 634, Records of the NYCBOE.

${ }^{47}$ Reprint of Negro History Week Supplement in New York Teacher News, January 25, 1958, Box 44, Folder 18, Records of New York City Teachers Union; The New York State Communist Party, Negro History Week: 1950, Folder 1, Series 634, Records of NYCBOE.
} 
“acceleration of Negroes to the North" spurred black's increasing representation in industrialized labor, leading African-Americans to become a "significant part of the labor movement when these industries were unionized in the labor upsurge during the New Deal." Thus, the article revealed how blacks joined unions to continue their fight for “civil rights and integration," and used these empowering institutions to apply political pressure to states to expand black vocational training and allow blacks into previously white trade schools. Similarly, the article, "The Struggle for the FEPC," illustrated how black mobilization and activism induced key political concessions in the fight for civil rights. After noting how blacks contested federal job discrimination during World War II by threatening a "full-scale March on Washington," the guide argued that the threat of this "impending crusade" ultimately created the FEPC, which was designed to stem workplace discrimination in defense industries. This spark in black activism and organization, the guide observed, ultimately spurred the executive creation of key protections that subsequently became a cornerstone of the "fight for a broad civil rights program.",48

Lastly, the article "Integration in Housing," spotlighted the complicity of Northern Jim Crow in sanctioning "segregation in housing which has actually been increasing in New York and making living conditions for the Negro and Puerto Rican people intolerable." While the article painted a stark portrait of the "terrible overcrowding, which exists in the ghettos," it also noted particular legislative remedies designed to ease housing concentration and "illegalize all housing segregation." Indeed, the methodical documentation of these existing laws, titles, and statutes, suggests that the

\footnotetext{
${ }^{48}$ Reprint of Negro History Week Supplement in New York Teacher News, January 26, 1957, Box 44, Folder 18, Records of New York City Teachers Union.
} 
guide specifically listed these protections to encourage for students and parents to draw on these protections when they encountered any vestige of Northern Jim Crow and racist discriminatory policy. ${ }^{49}$

Despite these optimistic portrayals, the Negro History supplements provided facts and statistics documenting that full racial equality was yet to be achieved. Examining the widespread inequalities blacks experienced in occupation, income, health, housing, and education, the Negro History supplements documented the sprawling impact of southern racism and Northern Jim Crow. One supplement highlighted a study from the "Architectural Forum," which, after surveying a single block in Harlem argued "At a comparable rate of concentration the entire United States could be housed in half of New York City." Other examinations juxtaposed racial disparities in healthcare, noting that black children suffered from infant mortality rates almost twice the rate of white children. And exploring education, one supplemented noted that schools spent $33 \%$ more on white educational expenditures compared to black children, while another statistic illustrated that white teachers in Mississippi earned 247\% more than their black counterparts. Another national survey found that the average income of white families was $184 \%$ higher than that of black families. ${ }^{50}$

Rather than merely citing the presence of institutional racism, the supplements complemented these racial statistics with accounts showing how African-Americans strove to surmount these racial barriers and create a more democratic society. Thus, the guide moved beyond showing how unions, legislation, and the executive branch advanced civil rights, by spotlighting black independence and autonomy in carving out

\footnotetext{
${ }^{49}$ Ibid.

${ }^{50}$ Reprint of Negro History Week Supplement in New York Teacher News, January 16, 1954, Box 44, Folder 18, Records of New York City Teachers Union.
} 
their own unique civil rights struggles. In this way, each supplement contained an activist tinge, which suggested that the barriers blocking racial equality could be turned with more organization, activism, and political pressure. One supplement described the efforts of civil rights leader Theodore Roosevelt Howard, whose ardent agitation and Southern civil rights crusades earned him the title of "shortest life expectancy in the United States." The guide observed that in the face of these threats, Howard voiced defiance. In a 1955 speech he promised that "armed with the Constitution of the United States of America" he would "stay in Mississippi" and that he had "reached the point of no return." Another "Breaking through the Color Barrier" article, spotlighted African-Americans' entrance into previously barred spheres in music, theater, and the arts. "The number of "firsts in the above partial list," the guide noted, is indicative of the problem Negro artists still have in breaking through the prejudice, which has confined Negro artists to stereotyped roles. ${ }^{51}$

Containing frequent dedications to the "unsung heroes in the current struggle for human rights" the guides elevated previously non-descript civil rights figures to valiant and heroic icons. In doing so, the supplement portrayed civil rights as an accessible movement that could be waged by any American with conviction and an earnest sense of social justice. Indeed, one supplement specifically proved this point by lodging the actions of everyday Americans within the nation's $20^{\text {th }}$ century quest for social equality. As the supplement noted, average American citizens "had taken part in all of America's wars, in the development of the trade union movement, in the campaign for women's suffrage, in the drive for a permanent FEPC, in the fight for free public education, and in

\footnotetext{
${ }^{51}$ Reprint of Negro History Week Supplement in New York Teacher News, January 25, 1958, Box 44, Folder 18, Records of New York City Teachers Union.
} 
attempts to extend the frontiers of democracy in the South." Thus, the TU used their supplement to laud the everyday actions of "democratic-minded Americans spurred to new, and in the South, often heroic efforts to wipe out every form of discrimination." 52

Acknowledging that distortions in black history created a diminished sense of self-esteem, the TU supplements also highlighted the deeds of militant black figures. While other Negro History supplements highlighted patriotic figures such as Crispus Attucks, or conventionally safe icons like George Washington Carver, the TU's Negro History supplement spotlighted contemporary figures who fought for civil rights and contested notions of racial inferiority. Weaving a tale that used black achievement to contest scientific notions of racial inferiority, one supplement explored the life of medical expert Charles Drew who as a "foremost authority in the field of storage for blood," was called upon to "direct a project which separated white and Negro blood." Indeed, the guide insightfully noted the "ironical" instance of the Red Cross calling upon an AfricanAmerican to engage in a procedure informed and shaped by ideals of white racial supremacy. In addition, the article "Jesse Owens vs. The Master Race," positioned the black Olympian as an icon who shattered national myths of racial superiority. As the guide indicated, "A quiet Negro from Ohio named Jesse Owens sent the Fuehrer scouring down from his exalted seat three times to avoid having to suffer the indignity of handing the gold medal . . . not only to Americans, but to NEGROES." Citing Owens' feat as one of the "greatest personal triumphs ever recorded in the Olympics Games," the guide

\footnotetext{
${ }^{52}$ Reprint of Negro History Week Supplement in New York Teacher News, 1956, Box 44, Folder 18 , Records of New York City Teachers Union; Reprint of Negro History Week Supplement in New York Teacher News, January 25, 1957, Box 44, Folder 18, Records of New York City Teachers Union.
} 
argued that Owens frustrated racists who wished to witness "the triumph of the 'master' race over the inferior nations of the world." ${ }^{, 53}$

Ultimately, the modern and militantly democratic accounts advanced by these "Negro History" supplements led to requests for copies from all across the nation and even the world. Flooding in from across the country, the union received thousands of requests for supplements from black schools, teacher-training institutions, libraries, and Southern colleges and universities. The supplements received press across the country, from both black and white newspapers, while the Boston Chronicle requested to reproduce entire supplements. Requests and gratitude came in from civil rights organizations, such as the NAACP, as well as the Southern Christian Leadership Conference, which indicated that Martin Luther King would be alerted to the supplements coverage. A supervisor of Southern schools requested 100 copies, as "often schools in the South do not get materials to work with in teaching boys and girls." After receiving a supplement from Langston Hughes, the San Francisco Negro History and Cultural Society requested 300 copies for its "first Negro History Week Program." And a teacher from Africa requested copies to be sent to Sierra Leone, as his students "became very interested in the article 'Negro Soldiers in the Civil War' as well in the one on 'Negro Folklore." ${ }^{54}$

The TU's intercultural campaigns proved to be a watershed moment for Cold War intercultural education. While historian Jonathan Zimmerman has argued that intercultural campaigns have rarely amounted to a "place at the table," the TU's campaigns managed to flip the tables on the schools and highlight administrator's

\footnotetext{
${ }^{53}$ Reprint of Negro History Week Supplement in New York Teacher News, January 16, 1954, Box 44, Folder 18, Records of New York City Teachers Union.

${ }^{54}$ Zitron, The New York City Teachers Union, 100; Taylor, Reds at the Blackboard, 256.
} 
sanctioning of racist and bigoted materials. Indeed, the TU distributed their intercultural materials to New Yorkers known for turning heated racial issues into emotional cause celebres. Thus, the union's innovative and pioneering studies, guides, and reports went to schools starved by McCarthyism and thus desiring any materials on race or civil rights. With its interculturalists either dismissed or under attack as communists, the TU still managed to deploy intercultural materials to bolster their image as an intercultural authority while calling the school's curricular practices into question. Thus, the TU spotlighted the philosophical incongruence of a school system that marketed its own programs of Human Relations while approving racist materials and dismissing educators who campaigned for racial equality. ${ }^{55}$

Historian Clarence Taylor has argued that by the early 1950s, the TU had become a potent force for civil rights, as the union's examination of discriminatory materials and practices ultimately secured the union support from "labor, civil rights, civic, and parent organizations as a strong voice for racial justice." While the union's fight for civil rights is indeed significant, equally as important is how the union managed to wage these campaigns against the backdrop of anticommunist campaigns and union attack. Working within a repressive Cold War climate, the TU argued that blacks did not seek to radically reshape the American nation, but rather to secure the uniquely democratic rights bestowed by their country. Thus, the TU avoided the fate of failed interculturalists who assailed an American nation that "none could sully or contest" by portraying civil rights as a realization of the nation's recent commitment to democracy, fair play, and equality of opportunity. These successful appeals ultimately led educators and students across the nation to read materials that portrayed equality not as a controversial issue, but rather as

\footnotetext{
${ }^{55}$ Zimmerman, Whose America, 7.
} 
an inevitable guarantee soon to be achieved by American democracy. Weathering anticommunist attack and facing the dismissal of its most inspiring interculturalists, the TU still managed to galvanize respect from teachers, educators, organized labor, civil rights coalitions, and parent organizations, even at the zenith of McCarthy's crusades. ${ }^{56}$

While debates over civil rights and intercultural education dominated national headlines, classroom explorations of Russia and Soviet affairs also proved to be contentious. During World War II, New York's schools endorsed Russian study as a means to facilitate international peace by fostering ideological understanding. As relations with the Soviets soured, however, many alarmists feared that educators could use explorations of Soviet society as a vehicle to tout the merits of Communist doctrine. These fears proved so pervasive that many teachers were "told not to discuss Communism" in their classes, while others abandoned discussions of the Korean War in fear of inviting potential discussion of the ideology. ${ }^{57}$ Other teachers abandoned their intercultural studies of the Russian people in order to focus on top-down explorations of Communist ideology. In shifting away from Russian culture to focus on Soviet ideology, Cold War classrooms were ultimately complicit in fostering the ideological polarization gripping the post-war world. Thus, the post-war curriculum similarly became a forum that exaggerated fears of Russian influence and the penetrating nature of Soviet doctrine.

A 1952 Look article, “Are U.S. Teenagers Rejecting Freedom?,” investigated these suspicions by reporting on a Purdue experiment that assessed "15,000 high school students on their attitudes towards controversial issues." Shrouding the ideology of the

\footnotetext{
56 Taylor, Reds at the Blackboard, 271.

57 "Public Pressure in Schools Decried," New York Times, 22 Nov 1951.
} 
Communist Manifesto and America's sacred documents in veiled and paraphrased questions, researchers attempted to find if more subtle means of indoctrination influenced student attitudes. Ultimately, researchers shockingly reported that "disguised Marxian beliefs appealed to many teenagers," while other students exhibited "strong Communist leanings." Asserting that teenagers seemed capable of "falling for the hysterical pitch of a home-grown Hitler or Stalin," the report indicated that students failed to detect "the totalitarian beliefs under which Rumanian schoolboys live." "Ill-equipped to recognize their basic freedoms," the article further warned that such democratic ignorance may lead America's youth to "throw away some of the most important freedoms guaranteed to all citizens of the United States." Ultimately, the article concluded by calling for lessons that helped students understand the "ideological conflicts of today" by having students juxtapose their democratic freedoms against the oppressive whims of Communist dictators. "With this enlightened educational approach toward the "isms," the report noted, "today's teenager will believe in the 'right' answers." 58

While many educators still avoided such lessons entirely, exercises that explored the contradistinctions of Soviet Communism and American democracy garnered widespread approval from both educators and the American public. ${ }^{59}$ These exercises supposedly avoided totalitarian indoctrination by asking students to impartially evaluate their own democratic government in the same light of Soviet Communism. Functioning as democratic forums, classrooms forged only the most sound and logical theories from

\footnotetext{
${ }^{58}$ William Houseman, “Are U.S. Teenagers Rejecting Freedom?," Look Magazine, February 26, 1952.

${ }^{59}$ Discussions over teaching Russia and Soviet Communism with a "pro-con" column can be abundantly found in a variety of sources. These approaches can be found in Reprint of Jack Estrin's "The Controversial Issue: A Re-examination," found in New York City Teachers Union Circular, "Shall Certain Ideas Be 'Out of Bounds.?," Box 8 Folder 3, Teacher Sees Error in Zeal for U.S. Ideas,” The New York Times, July 19, 1946.
} 
student competing opinions and deliberations. Students ultimately found their insights validated by comparing their observations with the similarly pro-democratic findings of other classes and peers. Buoyed by the democratic tools of fact-checking, independent thought, and collaboration, the process by which students came to their findings was as important as the democratic conclusions themselves.

Thus, while many Americans agreed to the incumbent necessity of maintaining democratic classrooms, there were heated disagreements over how democracy was to be realized in America's instructional space. As a result, some Americans came to contest the suppression of Russian instruction with similar democratic terminology employed by ardent Cold Warriors. In doing so, democratic progressives were able to voice progressive ideals of critical inquiry and democratic debate by couching their ideas within the ultra-patriotic lexicon of the Cold War. These contests over Russian instruction, all operating under the similar banner of democracy, reflected the contradictory roles of Cold War schools as both promoters of democratic expression and guardians of American ideals. In this sense, people divided over classroom disputes could both raise the banner of "democratic education," while using two different interpretations of democracy.

In combating the patriotic legitimizations of directed democracy advocates, democratic progressives claimed that the censorship of Russian study weakened America's democratic processes. In the educational magazine Civic Leader, William Shorrock took aim at Cold War traditionalists who argued that democracy would be strengthened by exploring only America's great democratic lessons. Shorrock argued that the exigencies of the Cold War required Americans to have a grasp of contentious global 
issues in order to render rational decisions as enlightened world citizens. If conducted properly, the sober analysis of such issues as "Free World vs. Communist World" would allow Americans to apply the "real meaning" of their democratic foundations to developing world issues. If schools neglected to familiarize students with the world's "major problems and challenges," Shorrock warned that Americans "shall never be able to uphold our heritage. ${ }^{90}$

Shorrock's ideas represented a more progressive current of post-war public thought that insisted democracy must grapple with contentious world issues in order to maintain its global relevance. After World War II, a coordinated group of educators mounted a clarion call for coordinated world bodies of knowledge that would combat the role of isolated ideologies in fueling conflict. Influenced by the UNESCO preamble"Since wars begin in the minds of men, it is in the minds of men that the defense of peace must be constructed"- - these thinkers espoused a liberal internationalist view of curricular affairs that envisioned a global education as a means to prepare future world citizens and engender lasting world piece. As John Blum describes, however, Americans remained skeptical of such internationalist approaches, as they "had to take special care not to be fooled, special care not to subordinate their interests to the influence of others, particularly at a time when the great economic and military strength of the nation, a reflection of its national virtue, made it unnecessary to yield to any antagonist." As internationalist views later became "contested, and in some circles, treasonous," some

\footnotetext{
${ }^{60}$ William Shorrock, “A Dangerous Tendency,” The Civic Leader, January 5, 1953.
} 
thinkers adapted their rhetoric to note how retreating from the study of Communism and world events diminished America's leadership capacity on the world stage. ${ }^{61}$

Throughout the 1950s, the National Council for Social Studies (NCSS) functioned as a powerful mouthpiece for this approach as the council often noted how the recent restraints on the discussion of world issues had placed educational leaders in "mental strait jackets." In 1951, the council garnered national attention for making the study of controversial issues and world affairs the thematic centerpiece of its conference. In its resolution, the NCSS observed how "two world wars and the problems left by each have involved the United States in problems of all parts of the world." At this crucial global juncture, however, American schools remained curiously silent on international issues.. Thus, one delegate claimed that leaving pressing international questions up to rivaling ideologies had "allowed communism to champion causes which lie in the rightful domain of democracy." In other instances, the NCSS warned that the educational trend toward indoctrination and a pronounced skepticism of world affairs may lead American youth to alienate themselves from international efforts seeking to build "lasting peace and world order." Thus, delegates called for school curriculum to adopt a comprehensive "global orientation" that prepared students to not only "desire a free world" but also to "bring it to pass." "If we are committed without reservation to the task of keeping America free, and progressively extending freedom to the world," one delegated noted, "then we must educate every boy and girl to understand these things." Embodying the patriotic

\footnotetext{
${ }^{61}$ John Morton Blum, V Was for Victory Politics and American Culture During World War II (San Diego: Harcourt, Brace, and Company, 1978), 304; Julian Huxley, UNESCO: It's Purpose and Its Philosophy (Washington D.C: Public Affairs Press,1947), 5;Robert Hutchings, "Are Our Teachers Afraid to Teach?," Look Magazine, March 9, 1954.
} 
vernacular undergirding the conference, one report declared that "in defending freedom to learn and freedom to teach, we are defending the democratic process itself.",62

Framing their critiques around issues of national security also enabled democratic progressives to argue that the intellectual negligence of Cold War curriculum placed postwar Americans in considerable danger." In his 1952 pamphlet," Studying the U.S.S.R,” Professor of Education Leonard Kenworthy highlighted how directed democracy approach to the study of the Soviet Union presented verifiable dangers to the American public. Dividing Russian study into two common approaches, Kenworthy asserted that the "Enemy" approach generalized Russia as a monolithic class of "barbarians," while the "Finding the Weakness" technique spotlighted the ideological failings of Russia in order to elevate the prestige of American democracy. Kenworthy believed that these instructional strategies reduced the sheer mass of Russian people to the misdeeds of their Soviet regime and the dangers of Communist ideology. Thus, Kenworthy argued that the school's exaggeration of Soviet danger created dangerous assertions, many of which had already gained currency in America's political sphere. For example, Kenworthy noted that with Russia presented as a looming and uncompromising ideological force, Americans increasingly gravitated to the notion that Communist ideas could only be eradicated through military force. In other instances, Kenworthy decried the school's complicity in underestimating Russian patriotism (which he saw as divorced from Communist ideology), overestimating Russian's discontent with their own regime, and the diminution of Russia's capacity for intelligence and technological sophistication. In doing so, these flawed assertions might lead Americans to underestimate the Soviet

\footnotetext{
62 "Communism Study Called Essential," The New York Times, November 25, 1951; "Public's Pressure in Schools Decried," The New York Times, November 22, 1951; "Freedom Stressed in Teaching Field," The New York Times, November 28, 1952.
} 
response to American militarization, downplay the sustained efforts required to carry out prolonged Cold War campaigns, and to remain oblivious to Russia’s increasing technological prowess. As a result, the professor argued for a restoration of critical thinking as a means to cultivate a more "intelligent handling" of international tensions. He argued that the "Social Science" approach ultimately enabled students to evaluate their "rivals and enemies" with the same rational analysis with which they evaluated "friendly nations." "If anything," Kennedy asserted, the high stakes of the Cold War necessitated that this mode of analysis "needed to be even more conscientiously applied here than elsewhere." 63

Not just content with promoting the study of the Soviet Union, democratic progressives also supported progressive ideas of inquiry and critical thought by explicitly binding these skills to Cold War concerns of national security. Democratic progressives argued by ignoring controversial issues schools were neglecting to cultivate crucial skills that were central to successfully navigating potential Cold War conflict. Professor Dorothy McClure of the City College of New York, noted how schools "were sending students out into a cold war world without the background and understanding of world affairs necessary to cope with the problems they will face as adults." Thus, McClure asserted that the expansion of the study of world history and world affairs in school curriculum were "vital" elements for "United States security." At a 1952 meeting of over 200 representatives of citizens groups and parent associations, respondents noted that restricting the "freedom to teach" hurt the American nation by engendering an intellectual maldevelopment of millions of its pupils. Similarly, more than 7,000 educators convened at the annual convention of the National Education Association (NEA) to discuss the

\footnotetext{
${ }^{63}$ Leonard Kenworthy, "Studying the USSR,” Box 8, Folder 3, Records of New York City Teachers Union.
} 
nation's pressing educational issues. The keynote speaker, rector Walter Turns, argued that the threat posted by America's "avowed enemies" was equally as dangerous as those domestic "false friends" who sought to stifle "creative thinking and honest inquiry." 64

Couching their ideals in concepts of freedom and national security, democratic progressives called for what Dewey branded as "scientific thinking," or the process of critical inquiry, tolerating dissenting views, and the unfettered exchange of ideas. Indeed, democratic progressives argued that neglecting to discuss controversial issues exposed students to totalitarian behavior in the classroom, while mitigating students' ability to grapple with Communist influence worldwide. To democratic progressives, the exclusion of controversial issues from the classroom had turned students into institutional embodiments of conformity, whose unflinching acceptance of drilled instruction made them acutely vulnerable to Communist propaganda. Democratic progressives further highlighted the perils in leaving students untrained in the "American traditions" of free inquiry and critical thought, observing that "the danger lies not in studying controversial issues ... but in neglecting them. Left on their own and without being trained how to think critically and clearly ... the youngsters would be more likely to go astray and make the wrong decisions." Thus, increasingly educators gravitated to the idea that "totalitarian communism," constituted a subject that necessitated exhaustive study coupled with the "formulation" of responsible judgments. ${ }^{65}$

Hitching America's heritage of intellectual freedom to America's larger Cold War campaigns allowed democratic progressives to skirt subversive associations while placing

\footnotetext{
64 "Live Issues Urged in Social Studies," The New York Times, November 27, 1954; "Public's Pressure in Schools Decried"; "Fearful Teachers Shunning Controversy, Survey Finds," The New York Times, June 29, 1953.

65 "Public's Pressure in Schools Decried."
} 
their curricular opponents on the defensive. Ever mindful of growing progressive stigmas, democratic progressives downplayed the progressive associations of these concepts and rather highlighted how debating contentious issues had governed America since its inception. Thus, critics managed to portray directed democracy as a corrupted understanding of democratic ideology as it reflected a tacit distrust in democracy's ability to guide students through the thickets of world affairs. In this way, directed democracy was not a manifestation but rather an abrogation of democratic ideals as it imposed artificial expressions of democracy instead of trusting the organic nature of the democratic process. Removed from its democratic bearings, the Cold War classroom thus lacked the critical inquiry and reason that had guided America through revolution, civil conflict, and two World Wars. In response, some schools were increasingly receptive towards discussing controversial issues. In one Connecticut school, teachers were told to foster discussions on current problems and controversial issues and to keep in mind "that we are training our pupils for life—-for making judgments — for seeking truth — and for contributing to the social progress of our time." Another school in Detroit received a letter from the Department of Instruction to discuss vital ideas, because the "absence of controversial issues in the classroom is sterilizing education to the point of impotence." In Des Moines, Iowa, a superintendent challenged students to "think upon an adult level" and granted the student body the autonomy to choose issues that they believed were "vitally significant to our social order."66

As these campaigns successfully mobilized public opinion, democratic progressives took advantage of an already incensed American public by seeking to

\footnotetext{
${ }^{66}$ Reprint from "Crisis in the Classroom" found in Academic Freedom Today... Reality or Relic, Box 1, Folder 9, Records of New York City Teachers Union.
} 
publicize the censorship of foreign affairs in the Cold War classroom. In March 1953, the TU issued the Questionnaire on Teaching of Controversial Subjects, asking parents, teachers, and students to review the "repression and censorship" occurring in New York's classrooms. Acknowledging that censorship existed in presentation as well as omission, the guide specifically requested reviewers to note the "lack of material" on important subjects while observing "special instances" of avoiding controversial issues in the classroom. The guide also investigated indoctrination's reach into testing and assessment, by asking students to note how "examination questions" slanted the process of inquiry. Indeed, one important objective behind the questionnaire was to raise the public consciousness surrounding controversial issues. With schools often subtly distorting or avoiding controversial questions, requesting the public to scrutinize the presence of stilted classroom instruction made the public aware of the presence of these daily instructional practices. Also, by employing polarizing terminology such as "avoidance, "distortion," and "slanted" to describe the treatment of controversial issues the TU reinforced its view that such practices did not bolster the nation's standing, but rather ran counter to America's “democratic tradition."

The findings generated by such questionnaires contested the school's approach toward controversial issues by bringing an overwhelming sense of curricular transparency to the American public. Throughout the 1950s, a proliferation of surveys, reports, and studies surfaced in newspapers and magazines documenting how the classroom's tendency to avoid world issues resulted in students' overwhelming lack of knowledge about world events. Released three weeks after the TU questionnaire, the New York

\footnotetext{
${ }^{67}$ Questionnaire on Teaching of Controversial issues, Box 14, Folder 6, Records of New York City Teachers Union.
} 
Times Magazine reported the findings of a study that assessed students and adults respective understanding of world issues. Asking students to define such concepts as authoritarianism, to contrast the distinctions between Soviet Communism and socialism, and to indicate the "causes of the breach" between Yugoslavia and the Soviet Union, the twenty-question test largely concerned itself with the defining characteristics of the Soviet Union and the Cold War. Ultimately, the article reported that both students and parents indicated an "appalling ignorance of the world world they live in." Noting that "there is something terribly wrong about teaching of the social studies in our public high schools," the report listed five conclusions from its study. Especially pronounced was the assertion that "teaching students to think is going out of style." 68

With the nation's "most serious educational crisis" in full swing, Americans developed a fascination with anecdotal statistics documenting the ailing conditions of their nation's schools. A 1954 report released by the NEA surveyed 522 school districts across the nation. Featured in newspapers across the country and released at a NEA conference of over 7,000 educators, the report found that discussions of race relations and Communism proved "too controversial" for Cold War classrooms. The same study reported that in its estimation, Cold War teachers had less academic freedom than teachers in 1940. An article scathingly entitled "Schools Get an 'F' in World Studies," declared that knowledge must be "held vital" after finding that 65 percent of American students neglected to take a course in World History. Another New York Times story documented the findings of three New York City teachers as they traveled throughout thirty-nine states to explore the instruction of current affairs and world issues. While the

\footnotetext{
${ }^{68}$ Although the term "climate of fear" can be found in many sources, a specific source where it was widely employed was in "'Climate of Fear"” In Schools Denied," The New York Times, May 21, 1953; Delbert Clark, "What We Don't Know," The New York Times Magazine, March 22, 1953.
} 
teachers observed a general willingness to discuss current affairs, they also witnessed a "tendency to teach current affairs in isolation from other studies and a failure to realize ultimately goals." Thus, the report called for pupils to develop competencies in analyzing and evaluating information from a multiplicity of contemporary sources documenting world problems. ${ }^{69}$

The surveys and reports created by such questionnaires played a significant role in mobilizing the American public and inciting educational outrage. Indeed, the centrality and importance of the public school in daily American life invited criticism from all avenues of the public. Distilling esoteric practices of pedagogy and curricular affairs into statistical anecdotes allowed for an ever-involved American public to render observations about the qualities of public education and the American school. And the fact that such studies rarely garnered media attention unless presenting a lop-sided or intriguing educational anecdotes often created highly critical approaches towards Cold War schooling. Exacerbating this process further, such findings were almost always accompanied by journalistic rebukes and prescriptions voicing how to improve a seemingly failed educational system. In some instances, such educational snapshots provided a window into post-war classrooms whose curricular affairs appeared too walled off or arcane to understand. In other instances, more intentionally alarming anecdotes, such as " $49 \%$ of teenagers believe large masses of people are incapable of determining what is good for them," and " $75 \%$ believe obedience and respect for

\footnotetext{
69 "Fear Poisons Classrooms, Says Educator's Report," Daily Worker, July 1, 1954;“"Fearful Teachers Shunning Controversy, Survey Finds," The New York Times, June 29, 1953; Schools Get an 'F' In World Studies," The New York Times, November 26, 1954.
} 
authority are the most important virtues children should learn," only served to foster alarm in a perennially paranoid Cold War world. ${ }^{70}$

These public critiques enlivened a diverse base of public constituencies that connected controversial issues to their nation's democratic values. New York Rabbi Louis Newman spoke to an audience of youths and their parents in asserting that "thought tyranny" would ultimately "raise a generation of robots and conformists, who are led to believe the finest days of civilization occurred when the Inquisition flourished in Spain." Additionally, Vice President of Ford Motor Company William Gossett, noted that the if "these self-established censors are to prevail, the risk is that the machinery of American education will become befouled with the sand of fear, and that the American ideal of academic freedom — of bold, adventurous thinking, of relentless search for truth—will be lost." At a forum panel in Long Island, students debated the effect of these developments in the classroom. One student indicated that school practices "denied students the right to decide for themselves on the merits of doctrines other than democracy." Another student argued that "free thought is being discouraged by fear, primarily of communism." In a 1952 meeting of the New York State Teachers Association, Eleanor Roosevelt asserted that America was elevated to greatness by maintaining a steadfast commitment to its traditional freedoms. Thus, Roosevelt argued that teachers should not shy away from discussing heated topics, and that the discussion of controversial issues should assume a

\footnotetext{
${ }^{70}$ Inquiry into the Effects of McCarthyism in the Field of Education, Box 1, Folder 9, Records of the New York City Teachers Union.
} 
measure of commensurate importance with military endeavors in eradicating the "threat of communism" worldwide. ${ }^{71}$

Debates surrounding discussing controversial issues in the classroom ultimately created enough public consternation to force New York's schools into defensive postures. In the immediate years of the Cold War, New York's teachers were warned "to guard opinions" and "not to allow personal prejudices to creep into the classroom presentation of controversial subjects." After the pronounced public blowback to such policies, however, the Board of Education abruptly departed from its earlier views. Conceding that "it would be inhumane to expect the teacher to know everything and believe nothing," the Board now called for educators to approach volatile subjects as no teacher "can pass through scenes of raging controversy" adorned in "suspended judgment and a pair of white gloves." Consequently, the Board declared that the controversial issue represented the "lifeblood of vital teaching in the Social Studies," and correspondingly, the school should function as the "practice ground for calm deliberation and generous give and take in subject-matter where there is a sharp division of opinion.” This policy shift transcended into the Board's Strengthening Democracy article, "Are We Discussing Controversial Issues," which endorsed controversial issues and sought to deflect accusations that New York's schools had succumbed to an instructional "climate of fear." In its defense of school policy, Strengthening Democracy claimed that the school's political investigations of New York teachers had no bearing on controversial issues, and that teachers showing any instructional hesitation as a result of such queries were "imposing an unnecessary censorship on themselves."

\footnotetext{
71 "Thought Tyranny Feared For Youth,” The New York Times, May 25, 1952; “Teachers Advised To Discuss Issues," The New York Times, September 28, 1952; “Ford Co. Veep Assails U.S. Thought Control," The Compass, September 12, 1952.
} 
By the mid 1950s, these seemingly insolvable debates placed Americans at a schoolroom impasse, as the nation agreed to the necessity of constructing democratic classrooms, while maintaining heated disagreements over what to teach in America's polarized instructional space. Indeed, the Board's uncharacteristic retreat from its rigid curricular views suggested the overwhelming extent to which democratic progressives influenced the conversations surrounding controversial issues. While some interpreted these concessions as a victory, other educational reformers voiced skepticism over the school's abrupt and seemingly convenient policy shifts. Indeed, concomitant with the school's open endorsement of controversial issues were the dismissals of teachers investigated for their subversive political views, and in some instances, classroom utterances and extra-curricular affairs. Furthermore, the Strengthening Democracy article, which was solely designed to assuage fears over instructing controversial issues, placed the burden of instructing in a "climate of fear" on teachers themselves while dedicating no attention to specific Board policies that had facilitated such an instructional panic. Complicating this divisive picture was that the fact that these staunchly opposing sides spoke in similar shades of democracy. Thus, the fiery campaigns of the democratic progressives always seemed to be accompanied by concessions that made their Cold War victories appear lukewarm in response. This ideological tug-and-pull continued throughout the 1950 s, eliciting public controversy wherever a contentious lesson and an irascible American public could be found.

In October, 1957, the appearance of a foreign deus ex machina circling throughout American skies forged a seeming consensus over classroom discussion of 
controversial issues. The launch of the Soviet satellite Sputnik dramatized the fiery societal tensions that had converged upon Cold War schools for over the past decade. To many observers, the presence of a satellite forged by Communist ideology painted the sky with an almost eerie spectre of what Soviet Russia could now accomplish. Lamenting that "Sputnik caught Americans napping," and that the "Soviets had ran away with the moon," the satellite led Americans to engage in an introspective bout of soul-searching concerning themselves and their besieged nation. Looking down from the sky and toward their schools, Americans wondered how and why their educational system had not only failed, but also fallen behind the totalitarian pedagogies seemingly fueling the rise of Soviet Russia. Thus, Americans overwhelmingly implicated their schools in the relentless quest to explain their nation's non-competitiveness. ${ }^{72}$

In relaying this narrative, however, historians have commonly emphasized how Sputnik spurred comprehensive changes in the funding of federal education, and the attention granted to the hard sciences. As the story goes, the President signed the National Defense of Education Act (NDEA) in response to nationalistic concerns that Sputnik could usher in a new wave of rocket-borne aerial warfare. Subsequently, the NDEA weaponized America's classrooms, as the federal government funded "research in areas deemed vital to national security, especially math, science, and foreign languages." Correspondingly, the influence of progressive education withered away, supplanted by a newly federalized system of education that sought the more tangible militaristic byproducts of the hard sciences. ${ }^{73}$

\footnotetext{
${ }^{72}$ William Caldwell, "Dumbness Revisited," Herald Tribune, November 7, 1957; Paul Dickson, Sputnik: The Shock of the Century (New York: Walker \& Company, 2001), 94.

${ }^{73}$ Dickson, Sputnik, 227.
} 
The momentous creation of the NDEA, forged in the wake of Sputnik, obscures how the rockets' red glare caused Americans to embrace more radical issues in classroom instruction. Similar to the exigencies wrought by World War II, the fear germinated by Sputnik created a more sobered instructional climate that stripped controversial subjects of their subversive nature. In doing so, the critiques of the democratic progressives surfaced throughout newspapers nationwide and witnessed a broader expression from America's political and educational critics. While many Americans placed the onus for America's non-competitiveness on the schools, an increasing number of critics also attributed the nation's dearth of scientific achievement to anticommunism and its faithful companion, Senator Joseph McCarthy. A month after the Sputnik launch, Senator Herbert Lehman delivered a speech "The Challenge of Sputnik and What It Means: A Program of Action for America, " where he lamented that McCarthyism's repression of "free and independent thinking" had created a "tame and silent generation—devoid of the leavening of radicals or radical thinking." "Perhaps the most damaging effect of these forces and factors," Lehman added, was that students had been lulled into a "state of complacency and apathy." In the Herald Tribune, Walter Lipmann authored a widely cited column that asserted, "What McCarthyism did to the inner confidence of American scientists and thinkers has constituted one of the great national tragedies of the post war era." Similarly, Harvard historian Arthur Schlesinger spoke at the $112^{\text {th }}$ meeting of the New York State Teachers Association, where he outlined the need for America to return to the principles of "old Americanism where critics and nonconformists were welcomed." Charging that Americans must support the "rebel, the heretic, the free inquirer, the skeptic, the intellectual," Schlesinger noted how America had become stifled by "un- 
American attempts to convert Americanism into dogmatic orthodoxy," which had "stood in the way of many constructive programs at home."74

Many critics believed that sharpening the minds of America's youth was not just necessary to improve America's intellectual psych, but also for students to confront the critical realities of a post-Sputnik world. To many Americans, the fact that the nation collectively underestimated Russia's capabilities illustrated that Cold War schools had neglected to cultivate skills of inquiry and critical thinking. As one observer queried, "how in the world did we ever con ourselves into making Russian dumbness . . . the difference between him and us." Other commenters observed that McCarthyism's penchant to badger "men who think" had created an instructional climate where Americans either lacked the ability to honestly assess Russia's abilities or feared that voicing such faith in Russia's capabilities may leave such observers open to Communist suspicion. Echoing the earlier warnings of Kenworthy, critics argued for a more reflective evaluation of Russia's abilities so that Americans could more effectively confront new Cold War obstacles. At a December, 1957 session on teaching about communism, a member of Pennsylvania's State Department of Public Instruction indicated that schools must "look at communism realistically, factually, analytically and objectively—not only at the faults but at everything and as it really is. It is better, far safer at the least, to overestimate the strength of an adversary than to underestimate it." Senator Lehman hoped such efforts would encourage students to embrace "debate and dissent--controversy and unorthodoxy" in order to "re-establish the search for truth, rather than

\footnotetext{
${ }^{74}$ The Challenge of Sputnik And What It Means: A Program of Action for America, November 25, 1957, Box 27, Folder 2, Records of the New York City Teachers Union; "McCarthyism A 'National Tragedy' Says Lippmann on US Lag in Science," New York Teacher News, October 19, 1957; "Eggheads Called Hope Of Country," New York Teacher News, Box 27, Folder 2.
} 
the acceptance of dogma." With Sputnik circling above America, critics believed, Russia must be discussed. ${ }^{75}$

This popular support thrown behind Communist instruction contested the years of curricular fear that had suppressed controversial issues. Merely a month after Sputnik's launch, the NCSS found that "academic taboos" had become weakened as teachers no longer feared that "teaching about communism" could be misconstrued as "teaching for communism." Indeed, the NCSS noted that widespread pleas for schools to grant students a "thorough understanding of controversial issues" ultimately granted educators "a great measure of freedom in the classroom." Consequently, the "study-no-evil " policy reinforced by directed democracy and curricular containment dissipated across the nation. By 1962, states such as New York, California, Florida, Georgia, and Louisiana passed "permissive" legislation that authorized schools to provide instruction on Communism as a staple of school curriculum. And while schools in Louisiana opted for the traditional "Americanism versus Communism" approach, there existed a rising chorus of critics who ordered that the "bad guys versus the good guys" approach played into the hands of the “enemies of American society” by suggesting "our society never needs reformation."76

The instructional enthusiasm supporting the instruction of Communism spurred the creation of a 72-page booklet, "Teaching about Communism," published by the National Association of Independent Schools. The product of interviews with "teachers and head masters across the country," the booklet documented that "evidence has become

\footnotetext{
${ }^{75}$ William Caldwell, "Dumbness Revisited," Herald Tribune, November 7, 1957; "Academic Taboos Found Weakened," The New York Times, November 29, 1957; "The Challenge of Sputnik And What It Means: A Program of Action for America," November 25, 1957, Box 27, Folder 2, Records of the New York City Teachers Union.

76 "Academic Taboos Found Weakened," The New York Times, November 29, 1957; "On Teaching About Communism," New York Times, December 19, 1962.
} 
overwhelming that responsible educators have made up their minds against crash programs designed to indoctrinate students." Noting that the scales have "tipped in favor of objective teaching," the booklet underscored the need to provide a comprehensive approach to teaching Russia's history that took into account the country's prevailing political and economic systems. It also elaborated upon the various ways history, political science, and economics could be employed to complement historical analysis. Similarly, the New York State Department of Education released its guide for social studies high school programs. While the guide acknowledged that Russia must be presented as posing a "clear and present danger," it emphasized that schools must spurn any instruction about communism that resorted "to the use of totalitarian propaganda techniques to achieve its ends." According to the New York Times, these curricular transformations signified a noted departure from the current orthodoxy. Instead of teachers frantically slanting their instruction in accordance with Cold War imperatives, the New York Times noted that New York's schools appeared to be teaching students how to conceptualize world issues, and in doing so, instructing the student "to be able to take a stand on issues of freedom versus oppression, under whatever titles and whenever they may arise." 77

Even the instruction of race and intercultural education were affected by Sputnik's sweeping orbit. In a nightly broadcast presented by Edward Morgan, the ABC Commentator reported on a scathing rebuke from the Wall Street Journal that connected the failings of Sputnik to America's racial practice:

How can we expect to compete with Moscow and its dynamically if savagely disciplined system not just in missiles and satellites but in all the broad fields of endeavor while we are wasting the human resources of more than 17 million Americans - more than a tenth of our entire population - by treating the Negroes

\footnotetext{
77"Study of Communism Gains in U.S. Schools as Debate on Aims Widens," The New York Times, July 3, 1962; “On Teaching About Communism," New York Times, December 19, 1962.
} 
to second-class citizenship or worse? How many potential Booker T. Washington's, George Washington Carvers, Marian Andersons, and Ralph Bunches, with their priceless talents, are being lost to the country by the blindness of bigotry. ${ }^{78}$

After Sputnik, interculturalists noted how the nationalistic desire to make American schools more competitive neglected to reach substandard black schools, where lacking conditions and outdated instructional materials placed African-Americans at an immediate intellectual disadvantage. In terms of curriculum, the NCSS reported while Southern teachers faced warnings not to teach about segregation "if they know what is good for them," other Southern communities made especial efforts to instruct the “integration question.” Less than one month after Sputnik, one Florida school system even proposed a course specifically exploring the issue of integration. Thus, the domestic events spurred forth by Brown v. Board and the international fear generated by Sputnik culminated to place America's discriminatory practices on the national stage. And while schools still sought out age-old explorations of cultural democracy, minority group achievement, and Human Relations to palliate racial tensions and advertise racial progress, Sputnik placed a renewed emphasis on race that endowed interculturalists with new "opportunities" to challenge the more narrowed contours of intercultural expression. ${ }^{79}$

The educational response to Sputnik illustrated the success of the democratic progressives' curricular campaigns. Indeed, the decision of many schools to embrace a more diverse and democratic curriculum was not an instantaneous realization spurred

\footnotetext{
${ }^{78}$ Excerpt From Nightly Broadcast of Edward Morgan, Box 27, Folder 2, Records of New York City Teachers Union.

79 “Academic Taboos Found Weakened," The New York Times, November 29, 1957
} 
forth by the Russian rocket but rather a decision informed by years of educational debate and dialogue. In the immediate years of the Cold War, democratic progressives responded to anticommunists suppression of Cold War curriculum with highly public campaigns that galvanized allies and garnered national attention. To accomplish this, democratic progressives worked within a web of unions, civil rights organizations, and educational and civic coalitions to publicize how the schools inability to study issues of race, Russia, and world affairs constituted a breach of America's democratic ideals. Exposing the contradiction between the nation's democratic ideals and the schoolroom's anti-democratic practice, numerous commentators assailed attacks on the study of Russia as a flagrantly anti-democratic practice that stood against America's heritage of debate and freedom of expression. In other instances, teacher unionists publicized passages from bigoted textbooks and argued that their presence violated the democratic basis of America's schools. This ultimately legitimized the TU's creation of updated "Negro History" supplements, which used modern scholarship to provide a more redeeming portrait of black life and racial reform.

The fact that these campaigns occurred against the contentious backdrop of the nation's post-war educational crisis ultimately amplified the amount of attention these campaigns received. Lodging their curricular campaigns within the democratic lexicon of the Cold War, democratic progressives contested the notion that their curriculum was subversive in origin by arguing that such topics could be used to combat the Cold War and highlight democracy's moral superiority. Consequently, these efforts helped normalize ideas of race and world affairs by portraying the study of these topics as a democratic tool to unite Americans and forge globally aware students. Thus, many Cold 
War schools responded to Sputnik by refusing to quarantine the nation's most pressing issues. Rather they gravitated towards the discussion of race and Russia as a democratic necessity to confront domestic issues and the Cold War's exigent realities. These efforts transcended into the 1960s, fueling the often contentious relationship between curriculum and democratic education that would grip Cold War schools for decades afterwards. 


\section{Chapter 6: Curricular Containment: Bureaucratic McCarthyism, Civic Education, and the Fight for a "Living Democracy"}

"Americans have thought it easier to instruct the young than to coerce the adult."

The Youthbuilders program, mostly overlooked in educational histories, represented the most expansive and influential civic program of 1940s America. Backed by the financial and educational support of Eleanor Roosevelt, Youthbuilders strove to immerse students in the process of "living democracy." This involved giving "students an opportunity to discuss controversial issues of their own choice, to interview leading citizens and to translate these experiences into constructive action in their own neighborhoods." Indeed, the Youthbuilders technique of "discussion plus investigation plus neighborhood action equals the solution" aimed to construct school-community relationships. In this vein, Youthbuilder teachers functioned less as authorities and more as civic mediators, familiarizing the class with the intellectual contours of their investigations, while helping students inject their inquiry into local communities. Students then used these educational "tools of democracy" to investigate racial discrimination in their neighborhoods, explore such civic issues as public housing and discuss world affairs. The final step of "concerted action" encapsulated the program's overriding practice of "group dynamics." This process involved dividing students into "action groups" as that debated civic solutions as a collective, and then used school and community resources to improve local issues. By 1949, however, Youthbuilders staff bowed to an orchestrated wave of school pressure and terminated their own program. Wondering why such a nationally heralded program had become so delegitimized and destroyed, the New York Teacher's Guild noted, "It is indeed difficult to find . . . the

\footnotetext{
${ }^{1}$ David Tyack and Larry Cuban, Tinkering Toward Utopia: A Century of Public School Reform (Cambridge: Harvard University Press, 1995), 2.
} 
sudden evaporation of enthusiasm with which Youthbuilders was hailed by the Board of Superintendents and the Board of Education in 1946, 1947, and 1948."

The same year of Youthbuilders dissolution, New York City Superintendent William Jansen took to the radio in an address that linked the designs of civic instruction with America's larger Cold War aims. Asserting that no American educator could remain neutral in the ideological conflict between democracy and totalitarianism, the Superintendent called for New York's teachers to impart a "genuine, deep-seated, lasting devotion to our American ideals and heritage" by immersing students in the "epic and dream of America." To imbue students "with the principles for which many great Americans have lived and died," Jansen proclaimed that Cold War pupils would study the Mayflower Compact, the Declaration of Independence, and Lincoln's Gettysburg Address. The Superintendent believed that an immersion in American exceptionalism, augmented by the lives and lessons of Washington, Jefferson, and Lincoln, would turn schools into democratic "centers" where American ideals were "taught and practiced." Furthermore, Jansen lamented the findings of a 1947 Carnegie Report, which argued that schools had "become exhibit halls in which the American value system is displayed with all others as one of a great variety of equally workable systems.” To Jansen, such developments diluted the historical pedigree of a democratic system of governance that had already demonstrated its ideological superiority. Thus, the Superintendent called for

\footnotetext{
2 "Youthbuilders Units Study, Then Act on Civic Issues," New York Post, July 27, 1948; Youthbuilders Teach Kids to Use Tools of Democracy," New York Post, July 27, 1948; "Youthbuilders' Lounge Aids Fight Against Delinquency," New York Post, July 28, 1948; "Pressure Groups Held School Peril," The New York Times, November 19, 1948; Board of Directors of Youthbuilders, Inc. response to Youthbuilders Report, Box 9, Folder 36, New York Teachers Guild Records, 1923-1957. 5279. Kheel Center for LaborManagement Documentation and Archives, Cornell University Library (hereafter cited as Records of New York Teachers Guild); Sabra Holbrook to James Marshall, 1 Oct 1948, Box 9, Folder 36, Records of New York Teachers Guild; "Report From Educational Policies Committee on the Youthbuilders Issue," Box 9, Folder 36, Records of New York Teachers Guild.
} 
teachers to indoctrinate students with democracy's merits in order to compel pupils' "allegiance" to the "bases of American freedom." Offering an illusion of choice, Jansen noted "when our pupils have compared the totalitarian way of life with the blessings that they enjoy as Americans, we need have no fear about the choice they will make."3

While Youthbuilders reveals a more diversified approach to civic instruction, historians have largely portrayed civic education as a one-dimensional field existing to anchor American interests and reinforce national values. Indeed, Jansen's more nationalistic interpretation of civic education was not an aberration but was rather part of a continuum of American thought that has maintained an almost "utopian faith" in

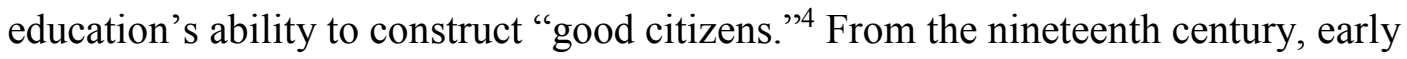
American founders sought to cement their country's fragile standing through a robust use of civic education aimed at cultivating Republican adherents. Writing to a nation seeking "reunion" from Civil War, textbooks called for the development of patriotic literacies as they urged youths to "love, honor and emulate" the iconic lives of Columbus, Washington, and Lincoln. Horace Mann, the educational leader of the "Common School Movement," saw critical approaches to civic education as impinging upon the expansion of public schools and stressed a consensual approach to civic education that highlighted values widely acknowledged "by all sensible and judicious men, all patriots, and genuine Republicans.” As America developed into a more diverse nation, civic education assumed a more complex social purpose, while its message remained similarly linear.

\footnotetext{
3 "Education to Strengthen Democracy," Transcript of Radio Broadcast by Dr. William Jansen to the Staff of the New York City Schools, January 31, 1949, Box 13, Folder 2, Records of New York Teachers Guild. ${ }^{4}$ In Tyack, David and Larry Cuban, Tinkering Toward Utopia: A Century of School Reform (Cambridge, Harvard University Press, 1995) both authors argued that that America has a historic legacy of approaching schooling as a "utopian" panacea in solving the nation's social, political and economic ills. Thus, Americans increasingly look towards public education in times of crisis, which creates impossible and often heightened expectations that the school's are blamed for not resolving.
} 
Whether "civilizing" the Indian "savage," "Americanizing" the immigrant, or

"democratizing" the incarcerated Japanese-American, civic education avoided nuance and complexity by relaying accessible narratives wrapped in nationalistic ideals of democratic progress and American values. ${ }^{5}$

Civic education's characterization as a field unquestioningly tethered to America's national designs and interests has informed historians' interpretation of the discipline's Cold War purpose. Historians Lawrence Cremin, Joel Spring, and Dianne Ravitch have all documented how Cold War policymakers turned to education to address America's varying and multitudinous post-war issues. ${ }^{6}$ Although accurate, national analyses on the federal government's budding relationship with the schools have tended to emphasize the perception that Cold War civic education existed solely to attack communism and tout American democracy. Indeed, David Marden argues that post-war schools played an active role in cementing the Cold War consensus by "shaping and passing on the American response to Cold War pressure." More recently, Carl Bankston and Stephen Caldas observed that Communism's "sense of siege" imbued the nation's "civic faith" with characteristics often identified with sects. Thus, the Cold War's heated ideological nature "encouraged a passionate sense of defensive nationalism, and a corresponding dedication to the cult of the nation, for which schools had become the

\footnotetext{
${ }^{5}$ David Tyack, Seeking Common Ground: Public Schools in a Diverse Society (Cambridge: Harvard University Press, 2003), 9-37.

${ }^{6}$ In Lawrence Cremin, The Transformation of the School: Progressivism in American Education, 18761957 (New York: Vintage Books, 1961), Cremin believed federal involvement in education stemmed from the desire to supply the requisite manpower and highly skilled labor for America's burgeoning post-war economy. Similarly, Joel Spring, The Sorting Machine: National Educational Policy Since 1945 (New York: Longman), stresses how public education increasingly became enlisted in the service of America's corporate liberal state in order to contain Soviet Communism and aid America's capitalistic expansion into foreign markets. While not addressing civic education, Spring does note that in channeling students to fuel economic and foreign policies, schools neglected to instruct students on how to democratically their social, political and economic rights. Lastly, Dianne Ravitch, The Troubled Crusade: American Education, 19451980 (New York: Basic Books Inc., 1983) views the federal involvement in schooling as a means to express and ensure citizens access and "equal opportunity" to America's schools.
} 
primary temples.” Arguing that culture reinforced the Cold War status quo, Stephen Whitfield observed that post-war instructional materials often embodied this exceptionalist impulse, portraying the "American way of life" as "fixed and stable, and as so entrenched that it could not have been changed with a lug wrench." Inside Cold War's textbook covers, “America was perfect: the greatest nation in the world, and the embodiment of democracy, freedom, and technological progress. For them, the country never changed in any important way: its values and its political institutions remained constant from the time of the American Revolution." Thus, the public memory of defense drills, "Burt the Turtle," and duck and cover, makes it difficult to uproot the perception that Cold War schools were anything other than sites of defensive preparation and patriotic instruction. ${ }^{7}$

In this chapter, I aim to challenge the static narrative of a post-war civic education marching lockstep with America's nationalistic designs. In doing so, I argue that World War II's popularization of democratic education endowed Youthbuilders with a civic authority that later contested the school's role in reinforcing the Cold War national consensus. Indeed, post-war Americans did not enter the Cold War with a pre-formulated concept of Cold War imperatives but rather a complicated democratic understanding informed by their aspirations and wartime experiences. The popularization of democratic education during World War II and the Cold War ultimately connected these tensions to public education, as Americans fought to promote their own normative conceptions of democracy within the schools. Thus, Youthbuilders capitalized on an American nation

\footnotetext{
${ }^{7}$ Cited in Edna Jan Jacobs, "Zeal for American Democracy: Civic Education and the Cold War" (PhD Diss., Southern Illinois University, 1999), 7, 22; Carl Bankston and Stephen Caldas, Public Education: America's Civil Religion, A Social History (New York: Teachers College Press, 2009), 79; Stephen Whitfield, The Culture of the Cold War, $2^{\text {nd }}$ ed. (Baltimore: John Hopkins University Press, 1996), 56-57.
} 
wavering in its conceptions of civic and democratic identity by positioning their program as a civic forum where students could resolve civic issues through a democratic process of debate, investigation, and collective action. These efforts ultimately served to legitimize the activist-oriented impulses of Youthbuilders in a Cold War known for branding such activities as subversive in character. Couched and rationalized through its commitment to democratic expression, Youthbuilders evolved into a program that was radical in approach, progressive in inspiration, and racially pluralistic in design.

While the Youthbuilders program's rise sheds new light onto post-war civic instruction, the fate of the civic program also provides a unique perspective to Cold War educational history. Education historians' tendencies to chronologically divide their studies of civic education has served to obscure long-term views of educational transformation. This demarcation between "pre" and "post" war eras ultimately treats Cold War educational programs not as a product of their influences, but rather as an invention of their time. ${ }^{8}$ Therefore, few education histories document the constancy of values and abrupt changes that gripped wartime programs as they transferred into the post-war period. ${ }^{9}$ Youthbuilders' World War II popularization and subsequent Cold War dismissal, however, illustrates America's changing views towards race, democracy and

\footnotetext{
${ }^{8}$ For an expanded discussion of this tendency, see O.L. Davis, "The American School Curriculum Goes to War, 1941-1945; Oversight Neglect and Discovery," Journal of Curriculum and Supervision 9, no. 2 (1993).

${ }^{9}$ Works that have largely omitted World War II from their post-war studies include This becomes especially problematic as some of educational histories most vital works have excluded the conflict from their examinations, including post-war studies such as Joel Spring, The Sorting Machine: National Educational Policy Since 1945, (New York: McKay, 1976) Dianne Ravitch, The Troubled Crusade: American Education 1945-1980 (New York: Basic Books Publishers, 1983), along with sprawling, comprehensive studies that exclude World War II, including Lawrence Cremin, The Transformation of the School: Progressivism in American Education 1876-1957; William Reese, America's Public Schools: From the Common School to "No Child Left Behind." $2^{\text {nd }}$ ed. (Baltimore: John Hopkins University Press, 2011); Dianne Ravitch, Left Back: A Century of Failed School Reforms (New York: Simon \& Schuster, 2000); Joel Spring, The American School: 1642-1996. $4^{\text {th }}$ ed. (New York: The McGraw-Hill Companies Inc, 1997); Marjorie Murphy, Blackboard Unions: The AFT \& the NEA, 1900-1980 (Ithaca: Cornell University Press, 1990).
} 
controversial issues. Analyzing civic education in the immediate years of the Cold War reveals that Americans embraced a more progressive form of civic instruction before anticommunism narrowed educators' options.

Lastly, charting the ascent of Youthbuilders during World War II reveals a unique portrait of how anti-communists dealt with a popular and nationally venerated program that included leftists in the post-war period. Historian Shelton Stromquist has called for more historians to focus on the "transformative impact" of local Cold War struggles, as city-wide conflicts provide new understandings of the "diverse outcomes" and political contests animating campaigns for "ongoing progressive politics." ${ }^{10}$ Indeed, support from leftist coalitions for Youthbuilders fundamentally altered how anti-communists attacked the civic program. Rather than contending with the program directly and risk public controversy for censuring freedom of expression, New York's Board of Education narrowed the program's progressive leanings by removing the activist methods that comprised the "heart" of the Youthbuilder program. By resorting to bureaucratic machinations, the Board was able was able to minimize the inevitable progressive backlash from Youthbuilders supporters while New York's schools were confronted with the "most serious crisis in history." 11 These acts of bureaucratic McCarthyism presaged the Board's highly publicized anti-communist investigations into New York's educators and teacher's unions. Therefore, illustrating how the Board of Education dealt with Youthbuilders reveals a subtle yet no less pernicious strand of anti-communism than educational historians have previously realized.

\footnotetext{
${ }^{10}$ Shelton Stromquist, Labor's Cold War: Local Politics in a Global Context (Chicago: University of Illinois Press, 2008), 1.

${ }^{11}$ Benjamin Fine, Our Children Are Cheated: The Crisis in American Education (New York: Henry Holt and Company, 1947), 1.
} 
In 1938 Sabra Holbrook established Youthbuilders, Inc. which was initially a private voluntary service organization that sought to teach school children responsible citizenship. Holbrook was a Vassar graduate from an upper class family, who as a student had done settlement work at Poughkeepsie's Lincoln Center. After graduation, she trained as a social worker and from that experience the ideas central to Youthbuilders emerged that "learning should be dynamic and grow out of group processes" that would ultimately give students experiences that "lead to some action." In many ways, Holbrook espoused a progressive vision of civic education that lamented the tendency of such programs to "impose ideas of good citizenship, or any other such cold-blooded abstraction from the top down."12

While Holbrook's ideas may not have been entertained in earlier decades, American's increasing perception of German totalitarianism as a "top-down" form of government, fomenting conflict and racist doctrine, led educators to champion organically democratic experiences in the classroom. With New York City schools engaging in sweeping curricular changes that sought to "fight racial hatred," engage in a "war on propaganda," "make schools "living examples of the American way of life," and to confront "dictator peril" through "practice of democracy in the school," Holbrook found Board members receptive to her educational proposals. ${ }^{13}$ Indeed, at one junior high school Holbrook witnessed students "bubbling over with ideas" about democracy and

\footnotetext{
12 "Holbrook, Sabra Current Biography," Biography Reference Bank (The H.W. Wilson Company, 1948)

13 "Schools Fight Racial Hatred," The New York Times, February 12 1939; ; "Racial Friction Noted," The New York Times, July 11 1943; "Schools in War on Propaganda," The New York Times, August 6, 1939; "Democracy Sought in Schools' Work," The New York Times, April 25, 1943; "Schools to Point to Dictator Peril," The New York Times, November 12, 1941; "Racial Tolerance Sought in Schools," The New York Times, April 23, 1944.
} 
politics but who had little "time or encouragement to express these ideas in schools." Thus, Holbrook began Youthbuilders as an afterschool discussion group at one solitary school, with the idea that proper democratic education should allow "kids to do it for themselves." Consequently, Holbrook's small program steady grew, receiving widespread acclaim from both administrators and students. ${ }^{14}$

The onset of World War II created a fertile educational climate that allowed the philosophies behind Youthbuilders to not only take hold, but to become the lynchpin of a truly democratic classroom. By 1944 Youthbuilders had grown to include 157 clubs, all which followed Youthbuilders pioneering technique of group activity and democratic action. In this exclusively trained technique, teachers avoided the conventional tendency to "tell the children what to discuss" and rather let a group of students pursue a community topic of their own collective interest. In what became the staple of the Youthbuilders program, students then selected group members to interview persons of "opposing opinions" on their selected topics of study. While students interviewed traditional political figures, Youthbuilders also encouraged students to interview individuals outside the more conventional domain of elected politics. Thus, students' interpretation of traditional politics was often contested by their discussions with civil rights activists, representatives from organized labor, and key figures from New York's array of grassroots and reform-minded coalitions. Ultimately, the final step of "concerted action" urged students to use their findings and research to discuss the best "method" to solve a community problem. Whether students pursued "segregation as it existed in the nation," explored rationing studies, or examined issues of religious friction, they presented their findings in classroom presentations, community meetings, or even their

\footnotetext{
14 "Ideas and Democracy," Newsweek, June 25, 1945;"Holbrook, Sabra Current Biography."
} 
radio program, "Let's Learn Together," where they passed on their thoughts to "their classmates and to their parents." Indeed, as executive director Sabra Holbrook noted, "What is important is that students begin with their own legitimate interest, and that they end with a project which answers a real community need."15

Youthbuilders secured widespread acclaim as its guiding philosophies were consonant with the wartime prescriptions laid down by New York's educators and administrators. For example, Youthbuilders' focus on local action coincided with the school's endorsement of communities as democratic "laboratories" that sharpened students' democratic consciousness. The programs insistence that students investigate issues of race and world affairs ultimately meant that it tackled the same issues totalitarian regimes were aiming to exploit. Furthermore, student examinations of newspapers and magazines for evidence of racial bigotry meshed with Professor Clyde Miller's decree that "Nazi labels" be subjected to "concurrent analyses" of the "reasons they are uttered" and the "phobias they involve." To many, these skills helped "combat" German propaganda that had "seeped into American classrooms" and were aggravating "racial antagonisms ... in schoolrooms throughout the nation." Lastly, Youthbuilders' subjection of social and civic ideas to intense scrutiny and debate was widely believed to expose the fraudulence of totalitarian ideals. Although students encountered minority viewpoints and radical opinions in their investigations, the ability to critically dissect these views aligned with Associate Superintendent Jacob Greenberg's claim that such abilities made students "immune and impregnable" to the presence of "Hitlerite" forces and "un-American organizations. " And bringing these educational efforts into nearby

\footnotetext{
15 "Young People Work to Make True Democracy a Reality," New York Amsterdam News, May 27. 1944; "Holbrook, Sabra Current Biography"; Youthbuilders Teach Kids to Use Tools of Democracy."
} 
communities meant students were cooperatively "living democracy" in their neighborhoods, instead of being drilled about democracy's merits in the fixed desks of an "authoritarian" classroom. ${ }^{16}$

Sabra Holbrook noted how World War II was an exciting time for engaging students in group activities of "living democracy." In the early years of the war, Holbrook contested the rising influence of "Nazi notions" by mixing Jewish students along with German pupils belonging to the Gleichschaltung, a German youth organization that indoctrinated students with Nazi ideology. With students unaware of the classroom's racial composition, Holbrook avoided the mistake of immediately addressing racial issues and rather had students debate unrelated topics in order to build a rapport and observe the sound ideology of each others opinions. When students did address racial issues that elicited "name-calling" and a flurry of "prejudices," Holbrook informed the German students that their fellow pupils were Jewish. "For the first time in that heated session," Holbrook noted, "there was dead silence." Indeed, Holbrook noted that in prior activities the Jewish students had "proved themselves good talkers" and had conversed with their German classmates in a way that contradicted "the pictures of Jews painted by the Nazi propaganda." Noting that "Hitler's doctrines weren't jibing with experience," Holbrook then turned the classroom into a democratic experience where students investigated the falsehoods perpetrated by Nazi ideology while deliberating civic and democratic issues. ${ }^{17}$

Youthbuilders programs also served as a powerful force in addressing the physical and often violent racial clashes that plagued New York's schools and

\footnotetext{
${ }^{16}$ The Committee for the Study of Practical Democracy in Education, 8, 23-29; "Schools to Open Tolerance Drive," New York Times, June 16, 1938; "Educators Warn of Growing Bias," New York Times, July 17, 1938; "Prejudice Scored as Bar to Culture," New York Times, May 14, 1939; Zitron, The New York City Teachers' Union, 95.

${ }^{17}$ Sabra Holbrook, Children Object (New York: The Viking Press, 1943), 12-15.
} 
playgrounds. In the late 1930s, the influx of African-Americans into a mostly white Manhattan neighborhood sparked the abrupt growth of youth gangs separated by age and race. Afterschool conflict proved so pervasive that policemen lined city blocks while directing students to "head straight home." Youthbuilders responded to these hostilities by organizing an assembly where a black labor leader compared the rise in gang violence to the "terrorism" inflicted by the Ku Klux Klan. Other Youthbuilders students created a process where they gradually created racially inclusive social circles that demonstrated the potential of interracial unity to their peers. When Youthbuilders leaders eventually queried gang leaders for the source of interracial violence, students found that racial tensions had increased after schools had reneged on their promises to open interracial gyms and form interracial bands and sports teams. When school officials balked at the notion that lack of interracial activities precipitated racial violence, gang leaders elected representatives who met with the principal and argued "We don't expect you to believe it is just because we say so... Therefore, we're asking you to please watch the school and neighborhood very closely for two weeks and just see how we keep our word." When the violence subsided, Youthbuilders teachers instructed students on how to gradually petition the school for their demands. As Holbrook later indicated, "[students' learned that the way to get equal opportunity for all is to work together for it, instead of to fight each other for it." 18

Youthbuilders students also organized to protest the "Jim Crow Blood Policy" of the American Red Cross. Responding to practices that segregated blood from white and black donors, Youthbuilders students arranged experiments with the schools science

\footnotetext{
${ }^{18}$ Holbrook, Children Object, 69-75; "Children's Night" at Club Halts Racial Feeling in New York School, New Journal and Guide, June 6, 1942.
} 
teachers at a large laboratory. With blood donated from a white Youthbuilders member and the black club President, students found that their results conclusively proved "that there was no difference" in white and black blood. Students then disseminated their findings to school science classes, reported their research in a student newspaper, and petitioned a school alumni to create over 200 posters that illustrated the "foolishness of blood segregation" and how the practice endangered "democratic principles of the American nation." When the Red Cross appealed to the Youthbuilders chapter for a monetary donation, students debated whether to support the war or oppose discriminatory policy. In an ultimate compromise, the students decided to wrap "each donation in a note of protest." 19

World War II solidified Youthbuilders' standing as the ideal wartime program to cultivate democratic processes and repel totalitarian ideology. These developments ultimately attracted the attention of school districts nationwide, which dispatched their best educators to observe this progressive pedagogy in practice. Consequently, Youthbuilders' success transformed the once private group into a flourishing organization, tasked with integrating its programs throughout the entire city's schools. With its own headquarters, executive members, and dedicated instructional staff, the program spread into 120 New York schools, became adopted by districts throughout Chicago and Philadelphia, and established "consultative relationships" in well over ten cities. The program's influence grew by the day as Youthbuilders hired a staff of credentialed educators dedicated to training New York's teachers in official Youthbuilder philosophies of group dynamics. Thus, New York went from having few schools that

\footnotetext{
19 "Blood Tests By Youths Hit Red Cross Jim Crow Policy," The Chicago Defender, April 24, 1943; "Pupils Assail Blood Policy," New York Amsterdam News, May 1, 1943; "Youth Group Seeks To End Discrimination," The Chicago Defender, May 22, 1943.
} 
provided instruction in group dynamics to maintaining a program that served as an educational model for the entire country. ${ }^{20}$

In 1943, Youthbuilders' popularity led Eleanor Roosevelt to visit Youthbuilders in order to observe the heralded program in practice. Speaking to over 1,000 Youthbuilder students, as well as educators increasingly contemplating the future postwar era, Roosevelt spoke of students' future role as "interested soldiers in the battle for peace." She proclaimed that free and open discourse developed "people of vision" who must investigate the underlying "economic, political, and social" questions of the post war-era. In this manner, Youthbuilders' cultivation of "analytical” habits was imperative for students to "become critical of what people say and weigh its content with the source of knowledge." The First Lady concluded by urging students to become disciplined in their thinking and to cooperate with other people. These traits, according to Roosevelt, meant students could be "great in their community" as long as they were "the factor that keeps it doing the right thing." 21

With the backing of Eleanor Roosevelt and New York's Board of Education, Youthbuilders entered the post-war period with a dedication to exploring civic issues. Barely a month after the dropping of the atomic bomb and Japan's subsequent surrender, 1,500 Youthbuilder students met to discuss the future of atomic weapons and the United Nations charter. In this large forum, students came to a consensus that atomic energy should "remain secret" until used for "constructive purposes," while noting that insuring "world peace" necessitated people to act like a "brotherhood of men" and engage as thoughtful "world citizens." A Philadelphia Youthbuilder forum investigated the potential

20 Ibid.

21 "First Lady Warns of Post-War Fight," The New York Times, June 6, 1943. 
of Russian conflict and highlighted the necessity of eradicating "social barriers" in order to inhibit diplomatic polarization and help opposing sides "get better acquainted." In other globally themed forums, 120 Youthbuilder groups throughout New York City dissected Cold War policy, the Marshall Plan, and developing issues in Palestine. By 1948, Youthbuilders students had engaged or interviewed "636 consultants," including Republican Presidential nominee Wendell Wilkie, Chinese Nationalist leader Chiang Kai-Shek, civil rights activists, and Catholic, Protestant, and Jewish clergy. ${ }^{22}$

Despite the international forums popularity, Youthbuilders students received the most attention for their grassroots initiatives and local action. By 1946, Youthbuilders won support from the Board of Education as a regular staple of "public school activity." As Youthbuilders staff trained teachers throughout New York in the programs principles, this encouraged students from various districts to work and collaborate in their investigations. Some of the more intriguing collaborations took place in East Harlem, an area known for educational experimentation, community activism, and agitation by civil rights activists and members of the Communist Party. For example, Youthbuilder students from East Harlem sponsored a community conference to explore issues of public housing and over-crowding. Mrs. Martha Zales, secretary of East Harlem's Health Committee, asserted the "destructive" and "psychological effects" of urban neglect stifled the borough's “civic pride." This campaign also brought Youthbuilder students into contact with radical congressman and civil rights activist Vito Marcontonio, who noted that tenements inherently diminished Harlem residents' potential for improvement and change. Students followed this conference with what the New York Times declared as the

\footnotetext{
22 "Youthbuilders Meet, World Issues Topic," The New York Times, September 28, 1945; "Youthbuilders'
} Lounge Aids Fight Against Delinquency"; "Youthbuilders Units Study, Then Act on Civic Issues." 
"fastest clean-up job in sanitation history." Working with community members and renting a sound truck to alert residents of the campaign, Youthbuilders students cleaned well over two tons of rubbish in less than thirty minutes. This civic clean-up ultimately spurred subsequent studies, including student investigations into the apparent disparities in public services throughout New York's neighborhoods. ${ }^{23}$

Another Youthbuilders campaign in East Harlem investigated the engrained racial stigmas behind Harlem's public perception. As one student indicated of his investigations, "We don't want false publicity. But some newspapers are hurting us by playing up racketeers and gangs. We want to show them the real Harlem. We want action." Students investigated the byproducts of these associations, including how Harlem's public perception affected residents' chances of encountering job discrimination. They sent out questionnaires to professionals and leaders with "roots deep in the area" in order to learn about their neighborhood's respective problems and accomplishments. Subsequently, students mapped out a course of action. They engaged with parents, activists, and community members to find out the origins of these distortions and their falsehoods. They cooperated with city departments and organizations to address the root of these issues. Subsequently, they contacted critical newspapers to take journalists on fact-finding tours of improved areas. ${ }^{24}$

Venturing beyond local discrimination, the same Youthbuilders chapter telegrammed President Harry Truman on matters of racial discrimination. In the

\footnotetext{
23 "Harlem Dirt Laid to Many Causes," The New York Times, December 4, 1948; Johanek, Michael and John Puckett, Leonard Covello and the Making of Benjamin Franklin High School: Education as if Citizenship Mattered (Philadelphia: Temple University Press, 2007) 212-214.

24 "Boys Irked By Critics of Harlem, Map Drive to Redeem Good Name," The New York Times, March 29, 1947; "Schoolboys Plan Survey in Harlem," The New York Times, April 19, 1947; Johanek, Michael and John Puckett, Leonard Covello and the Making of Benjamin Franklin High School, 212-214.
} 
telegram, Youthbuilders leaders voiced their displeasure that black students cancelled their visit to the "Capital of the United States" because of the discriminatory polices of Washington D.C. hotels. Noting their awareness of President Truman's stance on racial issues, the students respectfully suggested that the President "invite these students as your guests" in order for the students to visit and surmount racial barriers. Youthbuilders students subsequently used the novelty of the telegram to attract media attention for their cause while also spotlighting the discriminatory racial policies practiced by American hotels. ${ }^{25}$

Youthbuilders leaders also directed their activist energies towards media that perpetuated negative racial stereotypes of African-Americans. In particular, Youthbuilders students took umbrage at the recent introduction of "William Steamboat," a black character who was widely featured in Captain Marvel comics. In their assessment of the character, Youthbuilders students indicated that Steamboat represented a "thicklipped, kinky-haired" caricature who possessed an "ape-like stance and moronic drawl" that ultimately presented a stereotype that tended to "magnify race prejudice." The Captain Marvel editor informed Youthbuilders students that the comic similarly used exaggerative white characters "for the sake of humor." Yet, Youthbuilders students fired back that while white characters served as both "hero and villain," it was only the African-American character that played the role of "buffoon." Drawing a picture of Steamboat, one student added "this is not the colored race, but your one and a half million readers will think it is." When the magazine refused to remove Steamboat, Youthbuilders students circulated petitions "signed by people in every walk of life" and threatened to alert the general public to the presence of such toxic racial images that were

25 "Youthbuilders Ask President to Act," New York Amsterdam News, May 22, 1948. 
"doing a lot of harm and helping undermine better race relations." Ultimately, Youthbuilders action successfully secured the removal of Steamboat from Captain Marvel comics. Ironically, however, Steamboat's removal required the character to be "killed off," a violent act that also left the comic with no remaining black characters. ${ }^{26}$

In transferring their efforts from a war punctuated by Fascistic aggression to a conflict typified by anti-Communist hysteria, Youthbuilder leaders failed to understand how the Cold War precipitated a fundamental shift in educational thought. America's World War II embrace of democratic education lent credence to Deweyan beliefs that "freedom of inquiry, tolerance of diverse views, freedom of communication" combated totalitarian thought and formed the bedrock of the democratic method." Indeed, Americans advocated for these efforts not only in the United States, but internationally, as analysis, understanding, and inquiry were deemed crucial in combating the ideological incursions posed by Nazi Germany. Nevertheless, the onset of the Cold War spurred intellectuals to embrace a more triumphal, "relativist theory of democracy" in which democracy was "made normative" to American society. This assumption that American society embodied the ultimate "democratic ideal" facilitated the construction of democratic master narratives that strengthened America's world standing and propagation of democratic principles. Political scientist Edward Purcell noted that this "major transformation" in American thought prompted a more "strongly nationalistic stance in international affairs and to a fundamentally status quo orientation in domestic politics." Despite the movement's intellectual grounding, Cold War education's newfound role as an ideological "instrument of national purpose" meant these normative

\footnotetext{
26 "Kids Win War on Comic Book's 'Ape-like Villain," Afro-American, May 5, 1945; "Kids Crusade to Eliminate Stereotypes," Afro-American, September 8, 1945.
} 
representations of American democracy soon pervaded American schoolrooms across the nation. $^{27}$

Curricular representations of the relativist theory of democracy subsequently transformed the values embedded within civic education. Cold War civic programs now tended to stress the creation of a "competent citizenry" that emphasized a "passionate sense of defensive nationalism" over curricula that envisioned America as an imperfect nation enlivened by its potential for democratic perfectibility and reform. In this manner, invocations of democracy ceased to reflect a "call to social action," as in prior decades, but rather assumed more restrictive limitations that ensured American stability by marketing the nation's democratic promise. $^{28}$

This shift was most apparent in the Office of Education's 1948 launch of the "Zeal for Democracy" civics program. Alternatively billed as Education to Implant the Ideals and Benefits of Democracy and to Reveal the Evil Character and Tactics of Communism, the federally funded program aimed to spread "Zeal for Democracy" classes throughout the country with the explicit aim of inculcating "positive" attitudes regarding the American faith. Commissioner of Education John F. Studebaker, a key figure in the "Zeal for Democracy" movement, had previously championed the controversial debates in his federal "forum movement" as an ideological weapon to confront Nazi Germany and energize democratic principles. Yet, now the Commissioner wielded the federal

\footnotetext{
${ }^{27}$ John Dewey, "Freedom and Culture," in The Later Works of John Dewey, Volume 13, 1925-1953: 19381939, ed. Jo Ann Boydston (Carbondale: Southern Illinois University Press, 1988), 135; For discussion of the "relativist theory of democracy" see Purcell, The Crisis of Democratic Theory, 197-217; Hartmann, Education and the Cold War, 3, 4, 145; Dianne Ravitch, The Troubled Crusade, xii.

${ }^{28}$ Carl Bankston and Stephen Caldas, Public Education: America's Civil Religion, A Social History (New York: Teachers College Press, 2009), 79; Stephen Whitfield, The Culture of the Cold War, $2^{\text {nd }}$ ed. (Baltimore: John Hopkins University Press, 1996), 56-57.
} 
government to educationally indoctrinate democratic aims, lest students fall "prey of the most insistent propagandist, however implausible or subversive." 29

As the Cold War intensified, Youthbuilders insistence that students pursue and investigate their own social questions was ultimately unsuited to a Cold War environment that desired normatively crafted democratic instruction. In "Zeal for American Democracy,” Edna Jacobs argues that Studebaker's program contained a fundamental "cultural contradiction" that endorsed democratic values of deliberation and discussion while also restricting such practices in the name of national security. Cold War teachers subsequently straddled a precarious instructional position, as their activities had to maintain a pretense of critical thought and discussion while "guiding" students towards conclusions that aligned with the nation's foreign and domestic policy. Thus, whereas “Zeal for Democracy" activities were often predetermined and arranged, Youthbuilders democratic experiences were spontaneously forged by what topics students chose, who they interviewed, and the local action they implemented. This curricular fluidity meant that Youthbuilders students arrived at their own independent conclusions, as opposed to "Zeal for Democracy," which tasked teachers to "prepare wise and skilled defenders" against Communists who "prepare democracies for slavery.” Zeal for Democracy’s distrust of students' civic maturity was further evidenced in the program's lamentation that in a survey of 2,000 pupils in 68 classes, students interpreted "democracy" to mean "rights and privileges," while disregarding the "economic opportunities," "responsibilities," and potential for "success" accorded by democratic government. Thus,

\footnotetext{
${ }^{29}$ Hartmann, Education and the Cold War, 70-71; Robert Kunzman and David Tyack, "Educational Forums of the 1930s: An Experiment in Civic Education." American Journal of Education 111, no. 3 (May 2005): 320-340; Edna Jan Jacobs, "Zeal for American Democracy: Civic Education and the Cold War" (PhD Diss., Southern Illinois University, 1999), 127.
} 
Youthbuilders' insistence that students navigate themselves through the thickets of controversial issues was incongruent with citizenship programs directing students to run through the open fields of "The American Dream."

Beyond discussion, Youthbuilders' belief that "neighborhood action" and the "interview system" constituted "the heart" of their program ran contrary to the popularized principles informing Cold War citizenship programs. Zeal for Democracy aimed to familiarize students with the democratic process through immersion in student elections and city government, whereas Youthbuilders engaged students as advocates in surrounding neighborhoods and communities. While mainstream political venues were expected to winnow out student chances in encountering radicalism and subversion, community engagement potentially exposed students to the realm of activist political culture.

For example, Youthbuilders exploration of racial issues in East Harlem ultimately associated students with figures firmly rooted in activist networks of black political action, Communist advocacy, and organized labor. As historian Cheryl Greenberg observed in Or Does It Explode, the 1930s witnessed the "growth of an activist political culture in Harlem that spread from traditional organizations, such as the NAACP and the black churches, to the black community at large.” Thus, Youthbuilders students associated with representatives of this culture, especially in their work with East Harlem's Benjamin Franklin High School, an institution created to "play a central role in the social reconstruction in East Harlem." These efforts helped reinforce the experimental

\footnotetext{
${ }^{30}$ Edna Jan Jacobs, "Zeal for American Democracy: Civic Education and the Cold War," 3; "Zeal for American Democracy: Education to Meet the Challenge of Totalitarianism," Samuel Wallach Papers, 4-5, Series III, Box 2, Folder 27. Robert F. Wagner Archive at Tamiment Library (hereafter cited as Robert Wagner Archives).
} 
and community-minded impulses of many East Harlem residents, who sought to use the school as a "center for educational and democratic involvement" in order to address the "densely populated, chronically poor, and ethnically divided area of the city." In an era in which Communism threatened to seep into every ideological venue, the involvement of students with activists, grassroots coalitions, and unionists who comprised New York's "social-democratic polity" attracted scrutiny from New York's educational critics. ${ }^{31}$ Endowed with a public purpose of inculcating proper democratic values and empowered with the official ability of spreading instruction to other New York districts, Youthbuilders attracted the attention of The Tablet, a fervently anticommunist mouthpiece of Brooklyn's Catholic diocese. In a year-long series, The Tablet attacked the purportedly subversive potential embedded within the Youthbuilders program. The series commenced by noting the penchant of Youthbuilders children to investigate issues “centered around prejudice." According to The Tablet, students' tendency to render "pessimistic conclusions" in their investigations corresponded with the "common prejudices upon which the Communists and the professional promoters continually harp." Initially, The Tablet suggested that the Youthbuilders technique of interviewing the "opposing opinions on controversial issues" should be "screened" and supervised by reputable civic authorities. This was necessary, as the Catholic organ largely depicted the critical nature of Youthbuilder interviews as an ideological Trojan horse, subverting students' minds and infiltrating their investigations. Yet, as Youthbuilders programs spread to over 120 schools, The Tablet increased its urgent attempt "to save the children

\footnotetext{
${ }^{31}$ Newbold Morris to Vincent Impellitteri, May 9 1949, Box 9, Folder 36, Records of New York City Teachers Guild; Cheryl Greenberg, Or Does It Explode: Black Harlem in the Great Depression (New York: Oxford University Press, 1991), 10; Leonard Covello and the Making of Benjamin Franklin High School, 2-3; For Freeman's discussion of "The Rise of the Social-Democratic Polity," see Joshua Freeman, Working Class New York, 55-71.
} 
of our city schools from this influence." Consequently, the paper urged a wholesale dissolution of the entire interview process and mounted repeated calls for "an investigation of the Youthbuilder program." ${ }^{32}$

The Tablet's accusations carried considerable weight in the hyper-politicized climate of Cold War New York. Indeed, New York's democratic progressives noted the often convenient relationship between The Tablet's educational editorializing and corresponding Board action. Board activity, sometimes occurring within days of an incendiary editorial, seemed to lend credence to historian David Caute's claim that New York's anticommunist campaigns could be widely "regarded as a joint achievement of the Church and the Republican Party." These observations seemed especially accurate as the Board's ensuing investigations of Youthbuilders were often coterminous with The Tablet's accusations against the program. ${ }^{33}$

Although The Tablet played a role in the BOE's investigation, attributing these inquiries solely to journalistic pressures obscures the maelstrom of factors influencing educational policy. By 1948, New York's schools witnessed the fledgling alignment of anticommunist forces seeking to ferret out subversive activity within public education. These queries ultimately scoured every facet of schoolroom activity, spurring anticommunist investigations into teachers' unions, intercultural materials, teachers, textbooks, humanities courses, and magazines. As education became increasingly more political, civic education dominated the attention of critics anxious about the nature of America's democratic character and alarmists panicked about Communism's ubiquity.

\footnotetext{
32 Youthbuilders Inc. to Andrew Clauson, Nov. 22 1948, Box 9, Folder 36, Records of the New York Teachers Guild.

33 "Pressure Groups Held School Peril," The New York Times, November 19, 1949; David Caute, The Great Fear: The Anti-Communist Purge Under Truman and Eisenhower (New York: Simon and Schuster, 1978), 244.
} 
Consequently, the BOE produced the "Strengthening Democracy" series, an instructional complement to the "Zeal for Democracy" program that was designed to "aid teachers" in the "handling" of controversial issues. Declaring that teachers can no longer be "neutral" in presenting American ideals, the "Strengthening Democracy" bulletin asserted that "by proper questioning ... by frequent comparisons of American ways with those found in totalitarian countries, by anecdotes and by his own forceful attitude, the teacher can help to strengthen the loyalty of his pupils and deepen their pride in the American heritage." These developments occurred alongside the creation of a history curricular bulletin that warned New York teachers to not "allow personal prejudices to creep into their classroom presentation of controversial subjects." With the emergence of the Strengthening Democracy series the message was clear. In a Cold War climate where even a course on "Thinking In the Abstract" roused considerable controversy, the fluidly democratic experiences facilitated by Youthbuilders clashed with the statically democratic lessons citizenship programs were expected to impart. Indeed, schools desired students raised on democratic ideals not weened on democracy's imperfections. Starting in 1947 , the BOE commissioned the first of many investigations that ultimately narrowed the scope and expression behind the Youthbuilder program. ${ }^{34}$

For a variety of reasons, the Board handled their investigation of Youthbuilders with a considerable degree of political discretion. As previously addressed, Cold War schools had become the primary target for an American public concerned about what the schools should and could not accomplish. Swept up in this torrent of public condemnation, New York's Board of Education morphed into a decidedly political

\footnotetext{
34 "Teachers Warned to Guard Opinions," The New York Times, June 14, 1947; "Legion Seeks Ban on School Course," The New York Times, November 11, 1956; "Teacher Neutrality on U.S. Ideals Barred," The New York Times, March 28, 1949.
} 
creature. In his administrative study of New York's Board in 110 Livingston Street, sociologist David Rogers asserts that the city's schools were emblematic of large urban centers, where a coterie of insulated and elite public officials were also vulnerable to the "pressures and counterpressures" emanating from the various public interests that comprise "mass democracies." Rogers maintained that this "ecology" of political gamesmanship often served to stifle curricular innovation, as administrators had to adroitfully balance the municipal interplay of institutional interests, political leaders, and varying educational constituencies that either agitated for reform or anchored the status quo. $^{35}$

This political balancing act placed the Board in often contradictory positions, as the city's leftist coalitions and anticommunist networks came to view the schools as the primary institution to vie for ideological influence. For example, the 1946 reinstatement of racist civics teacher May Quinn, who declared that "tolerance was bunk," "Hitler had done some good for Germany," and "Negroes were happy before they knew about discrimination," ultimately sparked a protest rally of 4000 persons concerned about the Board's sanctioning of bigoted teachings. Yet, less than one year later, the Board faced mounting criticism from anticommunist organizations concerned about Youthbuilders' “excessive" focus on controversial issues such as racial prejudice. In a report on "District Problems," New York's schools noticed the tendency of local educational controversies to "produce tensions throughout the entire city." The report attributed these tensions to individuals and groups, who damaged the school's public reputation by avoiding official school channels and airing their grievances to the "press" and the "medium of mass

\footnotetext{
${ }^{35}$ David Rogers, 110 Livingston Street: Politics and Bureaucracy in the New York City Schools (New York: Random House, 1968), 6-9.
} 
meetings." Indeed, these incidents that the report documented were not sporadic but rather frequent, leading the Commission on Christian Social Relations to remark that "public education in New York ... during the past few years has been involved in one incident after another which tends to raise grave questions concerning the quality of the system and the policies and practices of the Board of Education." Noting the commission's charges, the New York Times observed that the "source" of these allegations endowed them with a "weight that cannot be ignored," and a gravity that necessitated "further inquiry."36

With its city "crackling with political energy," and its schools functioning as "magnets of dissent" in the most "serious crisis in its history," New York City's Board of Education learned from previous mistakes and used the school system's lumbering bureaucracy to mask its politically-motivated intent. ${ }^{37}$ Rather than overtly dismantling a nationally heralded program, the Board sought to dampen public reaction by deploying administrative machinations to mute and narrow the scope of Youthbuilders activities. Consequently, the Board advertised its reorganization of Youthbuilders with a considerable sense of promise. Fulfilling the accord that Youthbuilders and the Board agreed to in 1946, the Board called for Youthbuilders to be "integrated" into the school's official curriculum. "Study courses on training for responsible citizenship," the report suggested, were to have "practices and procedures made available to the classroom teacher." This necessitated a "reorganization" of the Youthbuilders program and the

\footnotetext{
36 "Preliminary Report on Bigotry and Bias in the N.Y.C. Public Schools," Box 2, Folder 3, New York City Teachers Union Records, 1916-1964. 5015. Kheel Center for Labor-Management Documentation and Archives, Cornell University Library (hereafter cited as Records of New York City Teachers Union); Bigotry in the New York City School System, n.d., Box 9, Folder 8, Records of New York City Teachers Union.

${ }^{37}$ Joshua Freeman, Working Class New York, 54;Dianne Ravitch, The Troubled Crusade, xii; Benjamin Fine, Our Children Are Cheated: The Crisis in American Education, 1.
} 
"expansion" of its operations. Board members praised these recommendations, noting that Youthbuilders "benefits will reach all pupils in the sixth through the ninth years." Board of Education Commissioner James Marshall similarly lauded these actions, noting that the Board did not want the Youthbuilders technique "to be a sort of Polish corridor in our school system or an island off the coast. We want it to be a part of our school system, and that is what this resolution does." ${ }^{\prime 38}$

As time progressed, however, Youthbuilder leaders noticed that Board suggestions for "integration," actually narrowed the scope of Youthbuilder activities while slating for the program's dissolution. Indeed, the Board's suggestion for "integration" of Youthbuilders did not entail an organizational expansion aided by increased funding and fueled by additional personnel. Rather, the school board argued that the "essential characteristics of the Youthbuilder program are already thoroughly infused in the schools" and that Youthbuilders contributions have "general acceptance today in the philosophy" of elementary and junior high school programs. Thus, the Board called for an "integration" of the Youthbuilders program by removing Youthbuilders staff from their community positions and "turning their efforts" to the "preparation of a curriculum pamphlet" to be made available to all schools. This "curriculum pamphlet" was supposed to outline the Youthbuilders' formula of the

\footnotetext{
${ }^{38}$ Perhaps as a testament to the shrouded nature of Board procedure, there is no official record of the Board of Superintendent's and the Board of Education's report on the Youthbuilders program. Instead, any references to these reports are referenced in a series of letters, press releases, and reports disseminated by the Youthbuilders program. Since Youthbuilders was a nationally recognized program, and since Youthbuilders cited and quoted specific pages, articles, and paragraphs of these reports in its letters to official Board members, I have decided to treat these passages as official quotations from Board reports. To find the Youthbuilders material I am referencing, see Board of Directors of Youthbuilders, Inc. response to Youthbuilders Report, Box 9, Folder 36, Records of New York City Teachers Guild; Sabra Holbrook to James Marshall, October 1, 1948, Box 9, Folder 36, Records of New York City Teachers Union; Newbold Morris to Andrew Clauson, May 9, 1948, Box 9, Folder 36, Records of New York Teachers Guild; Newbold Morris to Vincent Impellitteri, 9 May 1949, Box 9, Folder 36, Records of New York Teachers Guild; Youthbuilders Press Release, May 9, 1949, Box 9, Folder 36, Records of New York Teachers Guild.
} 
process of "dynamic group practices," while staff "collated research" to be used in subsequent curricular bulletins and brochures. In these materials, the Board called for the omission of the Youthbuilders "technique" that the anticommunist Tablet had so incessantly criticized. Indeed, interviews of "community leaders on controversial problems" were to be discontinued as a result of the Board's assessment that the process no longer constituted a "novel idea," and rather was a "device that has definite limitations." After describing its organizational model in a pamphlet, Youthbuilders was to be placed under the supervision of school principals, while its central office and staff were to be "discontinued as rapidly as feasible." 39

Contrary to a Board member's proclamations that these resolutions "widened and deepened" Youthbuilder activity, the Board knew that reducing the program to pamphleteering consigned the program to instructional irrelevancy. In every year since Youthbuilders' 1946 adoption as a staple of "regular public school activity," the Board budgeted Youthbuilders with a central office and staff tasked with the explicit aim of broadening Youthbuilders' principles. Indeed, instructing educators in the application of group dynamics required a rigorous process of in-service training accompanied by extensive assistance in helping teachers apply Youthbuilders concepts. This was necessary to uproot teachers from the more authoritative pedagogies that commonly typified traditional teacher programs and was designed to ensure that prospective Youthbuilders teachers did not corrupt the process of group dynamics by influencing the organic development of student investigations. On an instructional level, the construction of Youthbuilders curriculum also required extensive preparation by a scholarly staff

\footnotetext{
${ }^{39}$ Board of Directors of Youthbuilders, Inc. response to Youthbuilders Report, Box 9, Folder 36, Records of New York CTeachers Guild; Sabra Holbrook to James Marshall, 1 Oct 1948, Box 9, Folder 36, Records of New York Teachers Guild.
} 
immersed in the world of cutting-edge scholarship. The post-war influx of newfound interpretations emanating from the social sciences served to invalidate outmoded ideas regarding race and world cultures. As these findings were distilled into the nascent medium of intercultural education, this required a knowledgeable, extensively educated Youthbuilders staff to amass content fit for program activity. Youthbuilders central office staff not only integrated these source materials, but they also provided the institutional logistics in arranging city-wide intergroup meetings of program units. Harold Bordon, executive director of the New York Board of Rabbis, indicated these activities were crucial in providing "active co-operation among the many religious, racial, and national origin groups composing our cosmopolitan citizenry." 40

Therefore, defunding the nucleus of Youthbuilders effectively contained the program's spread into New York's schools, as implementation of its progressive curriculum was now left up to the individual initiatives of New York's teachers. As Howard Beale asserted in his landmark study Are American Teachers Free, teachers are less likely to engage in "experiments" of ideas and methods and more apt to "form habits" and routines influenced by their mentors and teacher-training institutions. Henry Linville, President of the New York Teachers Guild, echoed these ideas noting that the fundamental problem of "free and intelligent teaching" stemmed from "releasing the minds of teachers" and providing "inspirational leadership" that disseminated from official staff. With the program's training reduced to brochure bullet points,

\footnotetext{
${ }^{40}$ Sabra Holbrook to James Marshall, October 1, 1948, Box 9, Folder 36, Records of New York Teachers Guild; "School Board Urged to Act on Youthbuilders," New York Herald Tribune, July 23, 1948.
} 
Youthbuilders thus lacked the energy and instructional legitimacy to spread its materials and philosophies from 120 units to over 35,000 teachers. ${ }^{41}$

These findings were not lost on Youthbuilders staff who interpreted the Board's recommendations as a fundamental attack against their progressive program. In a series of reports and letters to Board administration, Youthbuilders staff critiqued the administrative body's evaluations of the Youthbuilders' program. They questioned how a four-page report, buried from the public and devoid of statistical data and professional research procedures ultimately informed the Board of Superintendent's later recommendations for Youthbuilders discontinuation. Youthbuilders leaders questioned why the Board's assertion that Youthbuilder philosophies had already been "infused" into the school's general philosophies was not supplemented with discussions of where these practices were implemented in schoolroom practice. They noted the parallels between The Tablet's critique of interviews, and the Board's subsequent dismissal of the practice as a "novelty." They cast suspicions upon the Board of Superintendent's removal of the practice, when only a few months before, head Superintendent William Jansen promoted the method as a process of assuring "active" citizenship by involving students in the "gathering of authentic data, the weighing of claims made by persons of conflicting opinions, and interviews with distinguished persons ... in order to carry out the suggested reforms and projects in which they have become interested." In a letter to the Board, Sabra Holbrook, executive director of Youthbuilders, assailed the school's confusion of the "concept and practice of teaching." As Holbrook wrote, "The fact that

\footnotetext{
${ }^{41}$ Howard Beale, Are American Teachers Free: An Analysis of Restrains Upon the Freedom of Teaching in American Schools (New York: Charles Scribner's Sons, 1936), 634-635; Henry Linville to William Bagley, February 14, 1931, Box 9,. Records, 1921-1942. 5445. Kheel Center for Labor-Management Documentation and Archives, Martin P. Catherwood Library, Cornell University.
} 
the Constitution of the United States states that 'the rights of citizens to vote shall not be denied on account of race' did not prevent Josiah Nixon from being shot when he tried to vote in Georgia. And the fact that 'curriculum bulletins' emphasize the importance of research activities and group dynamics does not mean that 35,000 teachers are using those techniques with their children." Lastly, Youthbuilder leaders wondered why school officials characterized their plan as a process of integration, when the "abolition of an active, trained staff seems more like a normal process of disintegration." Indeed, as the New York Teachers Guild wrote in their own assessment of the Board recommendations, "It is indeed difficult to find in the Superintendent's report adequate explanation for the sudden evaporation of enthusiasm with which Youthbuilders was hailed by the Board of Superintendents and the Board of Education in 1946, 1947, and 1948."42

As Youthbuilders and New York's press published reports documenting the program's newly diminished role, the city's network of leftist coalitions came to the program's defense. Rabbi Harold Bordon criticized the Board for reneging “on a previous policy of practical citizenship training," at a crucial juncture in American history "when our country is alerting herself to totalitarian aggression." Youth Director of the NAACP Ruby Hurly viewed the Board's action “with alarm," as Youthbuilders fought ignorance and prejudice while instructing "young people to recognize and follow through on their responsibilities as citizens" in a democratic society. Reverend Robert Searles, Director of the Protestant Council, praised Youthbuilders approach towards human relations, and indicated that his only critique of the program was that "its

\footnotetext{
${ }^{42}$ Board of Directors of Youthbuilders, Inc. response to Youthbuilders Report, Box 9, Folder 36, Records of New York Teachers Guild; Sabra Holbrook to James Marshall, October 1, 1948, Box 9, Folder 36, Records of New York Teachers Guild; "Report From Educational Policies Committee on the Youthbuilders Issue," Box 9, Folder 36, Records of New York Teachers Guild.
} 
resources are too meager and its support too limited." By November 1948, a meeting of over 300 "alarmed citizens" convened to "mobilize community sentiment to reverse" the Board's recommendations. Speakers from civic, labor, and civil rights groups denounced the school's attack on "freedom and inquiry," highlighted democracy's incumbent need to pursue controversial issues, and criticized the flagrant attempts to "undermine our democracy." Cecil Brown, member of the Youthbuilders Board of Directors, outlined the plight of Youthbuilders, calling the program's fate "frightening story" and a testament to "how easily sound public educational efforts can be sabotaged by splinter forces seeking to undermine them." Brown concluded by noting that all New Yorkers should recognize the "existence of a dangerous threat to free public education in New York." Ultimately, these actions failed to reverse Board action. As Brown so presciently predicted, the Board's bureaucratic attack upon the Youthbuilders program was but a portent of future educational reprisals aided by a far more sophisticated anti-communist machinery. ${ }^{43}$

Rather than concede to Board demands, Youthbuilders elected to remove their program from the schools before they witnessed its adulteration. In a letter to Board of Education President Andrew Clauson, Youthbuilders Chairman Newbold Morris requested the Board to strike their program from the school budget and withdraw the legally incorporated Youthbuilders name, as "only a functioning program of democratic research and action ... may be called a Youthbuilder program.” Morris indicated this act stemmed from the Board's decision to remove the "heart" of Youthbuilder activity, by eliminating the interview process and placing other democratic activities under the aegis of "untrained and already over-burdened principals." Morris alerted the Board that he

43 "School Board Urged to Act on Youthbuilders," New York Herald Tribune, July 23, 1948; "Seek to Retain Youth Group," The Sun, November 19, 1948; "Pressure Groups' Held School Peril," The New York Times, November 19, 1948. 
was not naïve to the program's plight, as Youthbuilders fate had a striking similarity to other progressive programs which had been slated to be "integrated," but had become "disintegrated to the point of becoming dangerous to pupils." "Had we foreseen the disastrous demise of the actual Youthbuilders program," Morris noted, "we should not have been so eager and insistent in 1946 to turn over the complete control and responsibility for the program to the Board of Education." 44

Three weeks later, Ethel Dammrich, a schoolteacher of twenty-three years, and supervisor to the Youthbuilders program, tendered her resignation to Superintendent William Jansen. In her letter, Dammrich wrote that in joining Youthbuilders, she was "thrilled" to bring the concept of "living democracy" to the schoolchildren of New York. By 1949, however, she noticed that the School Board's plans for Youthbuilders proclaimed to "outline future plans" for the program, "while in actuality, "outlining how to kill it, step by step." She highlighted the Board's semantic obfuscation, observing that “it is clear that terms such as 'decentralization', 'changes of organization', 'transitional' mean, in the school system vocabulary_no Youthbuilders' program." The progressive educator further noted that in her decades of experience she had become accustomed to such administrative "pussy-footing," and that, "all too often I have seen other honest efforts similarly relegated 'upstairs' with honor.” Thus, Dammrich tendered her resignation to maintain her "self respect," as she could no longer "remain a part of a school system where teachers live in fear." Dammrich concluded, noting that "there is no place in this system for the children-or for me." At a press conference staged at the

\footnotetext{
${ }^{44}$ Newbold Morris to Andrew Clauson, May 9, 1949, Box 9, Folder 36, Records of New York Teachers Guild; Newbold Morris to Vincent Impellitteri, May 9, 1949, Box 9, Folder 36, Records of New York Teachers Guild; Youthbuilders Press Release, May 9, 1949 ,Box 9, Folder 36, Records of New York Teachers Guild.
} 
Waldorf-Astoria, Morris lamented the events spurring the educator's resignation.

"Russian teachers sometimes jump out of windows to avoid an intolerable situation," Morris noted, "In America, it is still possible merely to walk out the door. This is what Miss Dammrich has done."45

As the Cold War progressed, the methods behind New York's civic instruction came to markedly differ from the progressive methods pioneered by the Youthbuilders program. Whereas Youthbuilders students had once debated the merits of public housing, the social impact of segregation, and the future of nuclear policy, New York's Strengthening Democracy series now asked students, "Is the passing of Stalin a blessing to mankind?," "What are the limits to academic freedom?" and "Has the modern woman failed in her responsibilities?" While Youthbuilders students interviewed political reformers, unionists, and civil rights activists, New York's "Civic Clubs" suggested that students interview more safe community figures, such as members of the Parents Teachers Association, and the capitalist friendly representatives of the Merchants Association. And whereas Youthbuilders students previously traced the origins of Harlem's racial stigmas, teachers now asked students to ponder the more racially neutral source of juvenile delinquency. Thus, civic education became stripped of its social purpose as it avoided the Cold War's pressing realities and operated under a façade of democratic engagement. In merely six years, New York's students went from welcoming

\footnotetext{
${ }^{45}$ Ethel Dammrich to William Jansen, May 12, 1949, Box 9, Folder 36, Records of New York Teachers Guild; "For Immediate Release," Youthbuilders Press Report on Ethel Dammrich's Resignation, Box 9, Folder 36 Records of New York Teachers Guild.
} 
the activist intonations conveyed by Eleanor Roosevelt to passively digesting a civic discipline committed to a repetition of heralded icons and "terminal blandness.",46

Observing these curricular transitions in practice, Sabra Holbrook spoke to the New York Times in what came to be a prescient and timeless takedown of civic education. The Youthbuilders' director blasted the penchant for civic instruction to lean on "pronouncements of teacher or text that democracy is beautiful," while neglecting to teach students "how to actually use the democratic process." In "educating for democracy and against totalitarianism," Holbrook believed civics classes had deployed trite and rote techniques, such as an "intellectual" approach that asked students to recite the judicial, executive, and legislative branches "from memory," and a "cloistered classroom" method that sought to elevate democracy's standing by barring students from examining other "forms of government." To Holbrook, the latter tactic required the Cold War teacher to "be equipped with blinders and earplugs" in order to disavow the maelstrom of variables influencing their students lives and the world's outer ideological struggle. In addition, Holbrook castigated the often contradictory treatment of America's heralded documents, noting that while it was a "fine thing" to teach about the Constitution, it was a dangerous practice to Cold War youths "how to use it. "Thus, Holbrook believed Cold War schools had relegated the democratic process to an extracurricular activity, where teachable moments such as student government had become "little more than a game in which children merely pretend to use the process of law." Holbrook believed such negligent civics instruction provided evidence of Representative Edward Hebert's admonition that

\footnotetext{
${ }^{46}$ Strengthening Democracy 5 (May 1953): 6., Series 664, Records of NYCBOE: A Teachers Guide (New York City Board of Education Records, 1950-1951), Series 667, Records of NYCBOE; Tyack, Seeking Common Ground, 40.
} 
"we assume a child knows what Americanism and democracy are, but we never explain what living in a democracy means."

Nevertheless, in its ten-year stint, spanning across the country, and serving as a national model in progressive pedagogy, Youthbuilders did expose thousands of students to the Deweyan experience of a "living democracy." In doing so, Youthbuilders achieved what many civic programs have set out to do but few have accomplished. Rather than searching for "consensus and avoidance of controversy," Youthbuilders asked its students to proactively question their nation's democratic ideals. This process stemmed from neither subversion nor cynicism, but rather an utmost belief that the edifice of American democracy could withstand both scrutiny and reform. Indeed, Youthbuilder leaders asked students to assess the level of democracy in America in order for pupils to experience the civic process of fact-finding, investigation, and critical thought. As students sought to reform their American nation, they became immersed in a democratic system built on the idea of societal imperfection and human perfectibility. With investigations encouraging collaboration that spanned across racial and ethnic lines, Youthbuilders fulfilled civic education's often difficult balance of espousing common values while cultivating a respect for racial and ethnic difference.

Positioning these activities as distinctly anti-totalitarian in character, Youthbuilders also achieved the peculiar feat of expanding its post-war operations while questioning America's Cold War consensus. The Board of Education's subsequent use of bureaucratic McCarthyism to attack Youthbuilders ultimately reveals a more subtle means of anticommunist attack in an iconic era remembered by show trails and witch hunts. Indeed, Youthbuilders fended off the more conventional means of anticommunist

47 “Democracy Study Held Inadequate," The New York Times, September 7, 1948. 
attack by couching its techniques in ideas of democratic expression and cooperation. Although Youthbuilders' practice of "living democracy" proved too radical for Americans committed to spreading democracy worldwide, anticommunists had to employ more subtle methods to attack the program. Rather than contending with the nationally acclaimed program directly, anticommunists resorted to administrative duplicity and bureaucratic machinations in order to neutralize the program's more radical methods. Although undoubtedly damaging, these backdoor approaches also suggest a legitimization of Youthbuilders democratic principles and a fear of the backlash from the civic and grassroots coalitions that comprised Youthbuilders support. Thus, the story of Youthbuilders reveals a progressive educational spirit that was not dead nor dormant, as some have suggested, but rather a force that was still thriving throughout post-war New York. As the more repressive means of McCarthyism coarsed throughout New York's schools, these progressive energies did not dawdle or subsist, but rather addressed these incursions head-on. Just as Youthbuilders captured the attention of early Cold War Americans, the battle over the schools instruction of "controversial issues" would soon rage throughout post-war New York. 


\section{Chapter 7: Conclusion}

Throughout the late 1940s and early 1950s, democratic progressives-consisting of labor unionists, educational reformers, civil rights activists, and religious leaderscomprised a grassroots coalition that thrust race, civil rights, Russia, and a progressive foreign policy onto the national stage. By situating the discussion of more radical educational issues as an embodiment of America's democratic tradition, democratic progressives contested anticommunists that sought to narrow educational discourse. In doing so, democratic progressives helped normalize the discussion of race, civil rights, communism and world affairs by combatting the notion that such ideas emanated from subversive origins. Consequently, democratic progressives accomplished a rather admirable feat. While progressive education faced an intense demonization in conservative political circles, democratic progressives promoted a return to Deweyan ideals of scientific thinking and critical thought by arguing that such skills were necessary to scrutinize Cold War events. In addition, democratic progressives contested post-war conservatives who sought to deploy the schools as an "instrument of national purpose" by advancing their own progressive tools to specifically confront America's Cold War campaigns. Aware that the policies and procedures of New York's schools galvanized national attention, educational activists publicized their efforts and surveyed the anti-democratic transgressions occurring throughout city schools. This publicity, couched in the ideological lexicon of the Cold War, forced schools to defer to the Cold War's democratic zeal and entertain educational policies they may have otherwise dismissed. While the influence of progressive education may have wilted alongside the ill-fated life-adjustment movement, a new band of democratic progressives found fertile 
ground for expressing progressive theory by binding such ideals to the Cold War's nationalistic purpose. ${ }^{1}$

The resultant scope and tenacity of these campaigns sheds new light on a Cold War era that has largely been misunderstood and neglected in educational histories. Indeed, the heated disputes surrounding the political and ideological space of the postwar classroom contest the notion that the 1950s were upheld by a stable Cold War consensus. Splashed across newspapers nationwide, these Cold War quarrels over education were inextricably linked to larger post-war conversations over civil rights, progressive education, and the Cold War. These curricular conflicts inhabited the same chronological trajectory of a post-war educational crises that began with the rise of McCarthy and ended with the ascent of Sputnik. Thus, while largely disavowed by historians, these conflicts over Cold War curriculum need to be considered as playing a significant role in fomenting the nation's mid-century educational crises

Lastly, this study combats the educational historian's tendency to disavow World War II's influence on post-war schools. The end of World War II fostered an intensely utopian style of educational thought as teachers approached the schools as the predominant site of ideological reconstruction. These intellectual energies that animated schools from World War to Cold War invite more examination, as teachers entered into these transitions with thoroughly progressive understandings of what the schools could accomplish. Indeed by repurposing their World War initiatives to address Cold War issues, interculturalists used the schools to introduce modern racial understandings that situated such scholarship to address the emergent ideals of civil rights. In doing so, these

\footnotetext{
${ }^{1}$ Dianne Ravitch, The Troubled Crusade: American Education, 1945-1980 (New York: Basic Books, 1983), xii.
} 
teachers and interculturalists impressed a distinct stamp upon New York's schools and communities. Mirroring the vanguard of civil rights activists discussed in Jacquelyn Halls “Long Civil Rights Movements, the TU forged a comprehensive civil rights campaigns that predated the mainstream emergence of the modern civil rights movement. ${ }^{2}$ Thus, exploring these intercultural crusades not only sheds new light on northern civil rights struggles, but it also reveals decades of professional, intellectual, and creative energies that went into producing some of the nation's most radical curriculum of the $20^{\text {th }}$ century.

Ultimately, the entirety of these efforts forced seemingly impenetrable Cold War schools into defensive postures, as educational authorities took action against racist curriculum and materials, while voicing an overt acceptance of controversial issues. And while some of these concessions were perhaps rhetorical or symbolic, the fact that New York's schools even engaged in such concessions, opened the schools to vulnerabilities for democratic progressives to exploit in subsequent campaigns. Indeed, while the fear generated by Sputnik spurred Americans to confront controversial issues, the $1960 \mathrm{~s}$ provided a spate of events, both foreign and domestic, that allowed educational activists to advocate for, yet again, the necessity of analytical and pragmatically rooted instruction.

Nevertheless, it should be noted that democratic progressives did not vanquish their anticommunist foes and achieve curricular victory. Indeed, these Cold Culture Wars meant that discussions surrounding democratic education were never truly resolved but rather vigorously contested, a testament to David Tyack's assertion that educational

\footnotetext{
2 Jacquelyn Hall, “The Long Civil Rights Movement and the Political Uses of the Past," Journal of American History 91 (March 2005).
} 
conflicts are not problems to "be eliminated," but rather manifestations of democracy

within public life. ${ }^{3}$

${ }^{3}$ In David Tyack, Seeking Common Ground: Public Schools in a Diverse Society (London: Harvard University Press, 2003), Tyack sees conflicts over public education as representations of democracy in a "diverse society." Jonathan Zimmerman similarly sees educational reoccurring "culture wars" as indicative of democracy's continuing vitality in public schools. Jonathan Zimmerman, Whose America: Culture Wars in the Public Schools (Cambridge: Harvard University Press, 2002). 


\section{Bibliography}

\section{Primary Sources}

Archival Collections:

AFT Local 2 Records \#5279. Kheel Center for Labor-Management Documentation and Archives, Cornell University Library.

Board of Education Records. New York City Department of Records. Municipal Archives.

Teachers Union of the City of New York Records \#5015. Kheel Center for LaborManagement Documentation and Archives, Cornell University Library.

Teachers Union of the City of New York. Records, 1921-1942. 5445. Kheel Center for Labor-Management Documentation and Archives, Martin P. Catherwood Library, Cornell University.

Newspapers/Periodicals:

Daily Worker

New York Amsterdam News

New York Post

The Daily Compass

The New York Times

The Tablet

World Telegram

Published Primary Sources:

Report to Honorable F. H. La Guardia on the Administration of Human Relations Program in New York City Schools. New York: City of New York Department of Investigation New York, 1945

\section{Secondary Sources}

Adler, Les and Thomas Paterson, "Red Fascism: The Merger of Nazi Germany and Soviet Russia in the American Image of Totalitarianism, 1930s-1950s." The American Historical Review 75, No. 4 (April 1970).

Alison, David. Searchlight: An Expose of New York City Schools. New York City: Teachers Center Press, 1951. 
Altenbaugh, Richard, ed. The Teacher's Voice: A Social History of Teaching in Twentieth-Century America. London: The Falmer Press, 1992.

Barnhisel, Greg and Catherine Turner, eds. Pressing the Fight: Print, Propaganda, and the Cold War. Amherst: University of Massachusetts Press, 2010.

Bankston, Carl and Stephen Caldas. Public Education: America's Civil Religion. New York: Columbia University, 2009.

Beale, Howard. Are American Teachers Free?: An Analysis of Restraints Upon the Freedom of Teaching in American Schools. New York: Charles Scribner's Sons, 1936.

Beineke, John. And There Were Giants in the Land: The Life of William Heard Kilpatrick. New York: Peter Lang, 1998.

Biondi, Martha. To Stand and Fight: The Struggle for Civil Rights in Postwar New York City. Cambridge: Harvard University Press, 2003.

Bullert, Gary. The Politics of John Dewey. Buffalo: Prometheus Books, 1983.

Burkholder, Zoe. Color in the Classroom: How American Schools Taught Race, 19501954. Oxford: Oxford University Press, 2011.

Burton, Ernest. Education in a Democratic World. Chicago: The University of Chicago Press, 1925.

Caute, David. The Great Fear: The Anti-communist Purge Under Truman and Eisenhower. New York: Simon and Schuster, 1978.

Covello, Leonard. "A Community-Centered School and the Problem of Housing," Educational Forum 7, (January 1943).

Cremins, Lawrence. The Transformation of the School: Progressivism in American Education 1876-1957. New York: Vintage Books, 1961.

Davis, O.L. "The American School Curriculum Goes to War, 1941-1945." Journal of Curriculum and Supervision 8, no. 2 (1993).

Dewey, John. Democracy and Education: An Introduction to the Philosophy of Education. New York: Macmillan, 1916.

Dewey, John. Education and the Social Order. 1936. Reprint, New York: LID Pamphlet Series, 1949. 
Dewey, John. The Reconstruction of the Democratic Life. New York: Charles Scribner's Sons, 1951.

Dewey, John. Liberalism and Social Action. New York: Capricorn Books, 1963.

Dickson, Paul. Sputnik: The Shock of the Century. New York: Walker \& Company, 2001.

Diggins, John. "Flirtation with Fascism: American Pragmatic Liberals and Mussolini's Italy," American Historical Review 71, no. 2 (January 1966).

Dodd, Bella. School of Darkness. New York: The Devin-Adair Company, 1954.

Dorn, Charles. American Education, Democracy, and the Second World War. New York: Palgrave Macmillan, 2007.

Dudziak, Mary. Cold War Civil Rights: Race and the Image of Democracy. Princeton: Princeton University Press, 2000.

Everden, Edward. "Teacher Training in a Democracy at War." Washington: American Council on Education, 1942.

Feffer, Andrew. "The Presence of Democracy: Deweyan Exceptionalism and Communist Teachers in the 1930s." Journal of the History of Ideas 66, no. 1 (January 2005).

Fine, Benjamin. Democratic Education. New York: Thomas Crowell Company, 1945.

Fine, Benjamin. Our Children Are Cheated: The Crisis in American Education. New York: Henry Holt \& Company, 1947.

Fitzgerald, Frances. America Revised: What History Textbooks Have Taught Our Children About Their Country, And How and Why Those Textbooks Have Changed in Different Decades. New York: Random House, 1979.

Foner, Eric. The Story of American Freedom. London: W.W. Norton \& Company, 1998.

Freeman, Joshua. Working Class New York: Life and Labor Since World War II. New York: New York Press, 2000

Gerstle, Gary. American Crucible: Race and Nation in the Twentieth Century. Oxford: Princeton University Press, 2001.

Giordano, Gerard. Twentieth-Century Textbook Wars: A History of Advocacy and Opposition. New York: Peter Lang, 2003.

Gutmann, Amy. Democratic Education. Princeton: Princeton University Press, 1987. 
Hall, Jacquelyn. "The Long Civil Rights Movement and the Political Uses of the Past." Journal of American History 91 (March 2005).

Hartman, Andrew. Education and the Cold War: The Battle for the American School. New York: Palgrave Macmillan, 2008.

Haynes, John. Red Scare or Red Menace: American Communism and Anti-Communism in the Cold War Era. Chicago: Ivan R. Dee, 1996.

Heins, Marjorie. Priests of Our Democracy: The Supreme Court, Academic Freedom, and the Anti-Communist Purge. New York: New York University Press, 2013.

Hofstadter, Richard. Anti-Intellectualism in American Life. New York: Vintage Books, 1962.

Hoggart, Richard. An Idea and Its Servants: UNESCO from Within. New York: Oxford University Press, 1978.

Holbrook, Sabra. Children Object. New York: The Viking Press, 1943.

Huxley, Julian. UNESCO: Its Purpose and Its Philosophy. Washington D.C: Public Affairs Press, 1947.

Isserman, Maurice. Which Side Were You On?: The American Communist Party During the Second World War. Chicago: University of Illinois Press, 1993.

Iverson, Robert. Communists and the Schools. New York: Harcourt Brace and Company, 1959.

Jacobs, E. Jan. "Zeal for Democracy: Civic Education and the Cold War." PhD diss., Southern Illinois University, 1999.

Jenlink, Patrick, ed. Dewey's Democracy and Education Revisited: Contemporary Discourses for Democratic Education and Leadership. Lanham: Rowman and Littlefield Education, 2009.

Johanek, Michael and John Puckett. Leonard Covello and the Making of Benjamin Franklin High School: Education as if Citizenship Mattered. Philadelphia: Temple University Press, 2007.

Johnson, Lauri. 'Making Democracy Real': Teacher Union and Community Activism To Promote Diversity in New York City Schools, 1935-1950." Urban Education 37, no. 5 (November 2002).

Karier, Clarence and Joel Spring. Roots of Crisis: American Education in the Twentieth Century. Chicago: Rand McNally, 1973. 
Keith, William. Democracy as Discussion: Civic Education and the American Forum Movement. New York: Lexington Books, 1972.

Kirkpatrick, William. Group Education For a Democracy. New York: Association Press, 1940.

Kirkpatrick, William. Intercultural Attitudes in the Making: Parents, Youth Leaders, and Teachers at Work. New York: Harper and Brothers Publishers, 1947.

Kuhn, Irene, "Your Child is Their Target," American Legion Magazine, June 1952.

Krug, Edward. The Shaping of the American High School. New York: Harper \& Row Publishers, 1964.

Lass, A.H. "War Activities in Our High Schools." High Points in the Work of the High Schools of New York City 24. (October 1942).

Lowe, Roy. Education and the Second World War: Studies in Schooling and Social Change. London: The Falmer Press, 1992.

Lybarger, Michael. "Origins of the Modern Social Studies: 1900-1916," History of Education Quarterly 23, no. 4 (1983).

Markowitz, Ruth. My Daughter, the Teacher: Jewish Teachers in the New York City Schools. New Brunswick: Rutgers University Press, 1993.

McKeon, Richard. Interrelations of Cultures: Their Contribution to International Understanding. Paris: UNESCO, 1953.

Michels, Tony. A Fire in Their Hearts: Yiddish Socialists in New York. Cambridge: Harvard University Press, 2005.

Mickenberg, Julia. Learning from the Left: Children's Literature, the Cold War, and Radical Politics in the United States. New York: Oxford University Press, 2006.

Miller, Ron. Free Schools, Free People: Education and Democracy After the 1960s. State University of New York Press: Albany, 2002.

Montalto, Nicholas. "The Forgotten Dream: A History of the Intercultural Movement, 1924-1941.” PhD diss., University of Minnesota, 1977.

Murphy, Marjorie. Blackboard Unions: The AFT \& the NEA, 1900-1980. Ithaca: Cornell University Press, 1990. 
Myrdal, Gunnar. An American Dilemma: The Negro Problem and Modern Democracy. New York: Harper \& Brothers Publisher, 1944.

Nadel, Alan. Containment Culture: American Narratives, Postmodernism, and the Atomic Age. Durham: Duke University Press, 1995.

Naison, Mark. Communists in Harlem During the Great Depression. New York: Grove Press, 1984.

Ottanelli, Fraser. The Communist Party of the United States: From the Depression to World War II. New Brunswick: Rutgers Universit Press, 1991.

Pak, Yoon. "If there is a Better Intercultural Plan in any School System in America, I Do Not Know where it is": The San Diego City Schools' Intercultural Education Program, 1946-1949," Urban Education 37 (November 2002).

Parkerson, Donald and Jo Ann Parkerson. Transitions in American Education: A Social History of Teaching. New York: Routledge Falmer, 2001.

Perrett, Geoffrey. Days of Sadness: Years of Triumph: The American People, 1939-1945. Madison: University of Wisconsin Press, 1985.

Perrillo, Jonna. Uncivil Rights: Teachers, Unions, and Race in the Battle for School Equity. Chicago: The University of Chicago Press, 2012.

Perlstein, Daniel. Justice, Justice: School Politics and the Eclipse of Liberalism. New York: Peter Lang, 2004.

Peterson, Paul. The Politics of School Reform: 1870-1940. Chicago: The University of Chicago Press, 1985.

Podair, Jerald. The Strike that Changed New York: Blacks, Whites, and the Ocean HillBrownsville Crisis. New Haven: Yale University Press, 2002.

Powdermaker, Hortense. Probing Our Prejudices: A Unit for High School Students. New York: Harper and Brother Publishers, 1944.

Purcell, Edward. The Crisis of Democracy Theory: Scientific Naturalism \& The Problems of Value. Lexington: The University Press of Kentucky, 1973.

Preston, William. Hope and Folly: The United States and UNESCO, 1945-1985. Minneapolis: University of Minnesota Press, 1989.

Ravitch, Dianne. The Great School Wars: A History of Public Schools as Battlefields of Change, New York City, 1805-1973 (New York: Basic Books. Inc., 1974) 
Ravitch, Diane. The Troubled Crusade: American Education 1945-1980. New York: Basic Books Publishers, 1983.

Ravitch, Diane and Ronald Goodenow. Schools in Cities: Consensus and Conflict in American Educational History. New York: Holmes and Meier, 1983.

Reese, William. America's Public Schools: From the Common School to No Child Left Behind. Baltimore: John Hopkins University Press, 2011.

Reich, Robert. The Power of Public Ideas. Cambridge: Harvard University Press, 1988.

Rogers, David. 110 Livingston Street: Politics and Bureaucracy in the New York City Schools. New York: Random House, 1968.

Schrecker, Ellen. Many are the Crimes: McCarthyism in America. Boston: Little, Brown, and Company, 1998.

Schaffer, Robert. , "Multicultural Education in New York City During World War II." New York History (July 1996).

Selig, Dianna. Americans All: The Cultural Gifts Movement. Cambridge: Harvard University Press, 2008.

Sitkoff, Harvard. "Racial Militancy and Interracial Violence in the Second World War," Journal of American History, LVIII (December, 1971).

Silver, Harold. Education as History: Interpreting Nineteenth- and Twentieth Century Education. London: Methuen, 1983.

Spring, Joel. The American School: 1642-1996, $4^{\text {th }}$ ed. 1986. Reprint, New York: The McGraw-Hill Companies, Inc, 1997.

Spring, Joel. Conflicts of Interests: The Politics of American Education, $3^{\text {rd }}$ ed. 1988. Reprint, Boston: McGraw Hill, 1998.

Stromquist, Shelton. Labor's Cold War: Local Politics in a Global Context. Chicago: University of Illinois Press, 2008.

Sugrue, Thomas. Sweet Land of Liberty: The Forgotten Struggle for Civil Rights in the North. New York: Random House, 2008.

Taft, Phillip. United They Teach: The Story of the United Federation of Teachers. Los Angeles: Nash Publishing, 1974.

Taylor, Clarence. Knocking at Our Own Door: Milton A. Galamison and the Struggle to Integrate New York City Schools. New York: Columbia University Press, 1997. 
Taylor, Clarence. Reds at the Blackboard: Communism, Civil Rights, and the New York City Teachers Union. New York: Columbia University Press, 2011.

Thursfield, Richard, ed. The Study and Teaching of American History. Washington D.C: National Council for the Social Studies, 1946.

Tyack, David, ed. Turning Points in American Educational History. Toronto: Blaisdell Publishing Company, 1967.

Tyack, David. The One Best System: A History of American Urban Education. Cambridge: Harvard University Press, 1974.

Tyack, David. Public Schools in Hard Times: The Great Depression and Recent Years. Cambridge: Harvard University Press, 1984.

Tyack, David and Larry Cuban. Tinkering Toward Utopia: A Century of School Reform. Cambridge: Harvard University Press, 1995.

Tyack, David. Seeking Common Ground: Public Schools in a Diverse Society. London: Harvard University Press, 2003.

Tyack, David and Robert Kunzman. "Educational Forums of the 1930s: An Experiment in Adult Civic Education." American Journal of Education 111, no. 3 (2005).

Westbrook, Robert. John Dewey and American Democracy. Ithaca: Cornell University Press, 1991.

Whitfield, Stephen. The Culture of the Cold War, $2^{\text {nd }}$ ed. Baltimore: John Hopkins University Press, 1996.

Zimmerman, Jonathan. Whose America?: Culture Wars in the Public Schools. Cambridge: Harvard University Press, 2002.

Zitron, Celia. The New York City Teacher's Union 1916-1964. New York: Humanities Press, 1964.

Zoll, Allen. They Want Your Child!: The Real Meaning of Federal "Aid” to EducationShowing its Relation to the Whole Marxist Movement. New York: National Council for American Education, 1949. 